\title{
The Lords of the Northern Treasures: The Development of the Tibetan Institution of Rule by Successive Incarnations
}

\author{
Jay Holt Valentine \\ Baltimore, Maryland \\ B.A., University of Delaware, 2002 \\ M.A., Naropa University, 2004 \\ A Dissertation presented to the Graduate Faculty \\ of the University of Virginia in Candidacy for the Degree of \\ Doctor of Philosophy
}

Department of Religious Studies

University of Virginia

August, 2013 


\section{Abstract}

This dissertation is a case study that critically examines the development of one particular incarnation lineage, the Lords of the Northern Treasure Tradition. The analytical goal of the case study is to develop the foundations of a theoretical framework for the further analysis of the social institution of rule by successive incarnations, which is a ubiquitous form of institutional leadership in Tibet. As the $14^{\text {th }}$ Dalai Lama advances in age, his status as an "incarnate lama" (sprul sku) will increasingly become more important as the world turns its attention to the subject of his succession. This popular interest is mirrored by an equal measure of academic attention in the form of a series of books, dissertations, and conferences that also examine the subject of serial incarnation.

This investigation of the development of the incarnate Lords of the Northern Treasure Tradition (byang gter) is based upon a series of biographies and autobiographies of the early patriarchs of the tradition. This collective of charismatic leaders include: Nanam Dorjé Dujom $\left(8^{\text {th }}\right.$ c. $)$, Tropu Lotsawa $\left(13^{\text {th }}\right.$ c. $)$, Gödem Truchen $\left(14^{\text {th }}\right.$ c. $)$, Lekden Dorjé $\left(16^{\text {th }}\right.$ c.), Ngakgi Wangpo $\left(17^{\text {th }}\right.$ c. $)$, and Pema Trinlé $\left(17^{\text {th }}\right.$ c. $)$. The resulting perspective offers insight into the transformation of a non-monastic Nyingmapa tradition into one of the most important Nyingmapa monasteries of the seventeenth century. This dissertation also examines the implicit shift in meaning of the term "tulku." I argue that this term that was originally used to describe the Buddha as a "magical emanation" of enlightenment, is best translated as "incarnation" or "steadfast incarnation" when used in the context of the tulku system to describe patriarchs that reliably return to human form. 
Dedicated to the three loves of my life:

Catherine, Shanti, and Naomi 


\section{Table of Contents}

Abstract. ii

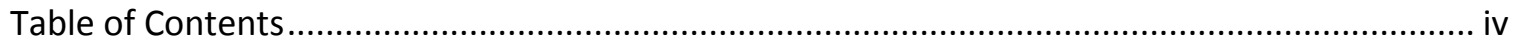

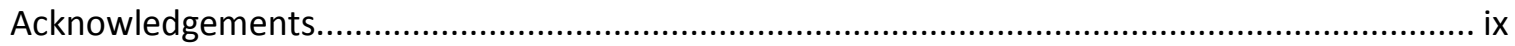

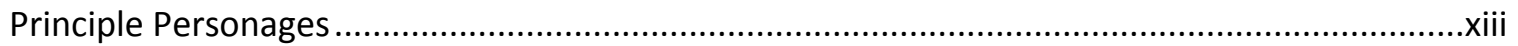

The Lords of the Northern Treasures (Tibetan Incarnations) ................................................iii

Incarnations of the Brother Lineage ...................................................................................ii

Incarnations of the Yölmopa Masters.......................................................................................

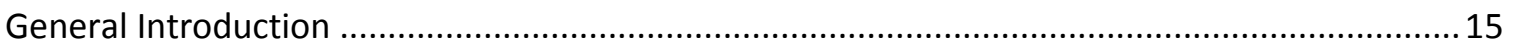

A Case Study of an Incarnation Lineage: The Lords of the Northern Treasures ......................... 2

Intersecting Institutions: Treasure Revelation \& Rule by Incarnation ........................................ 5

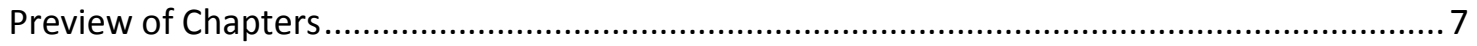

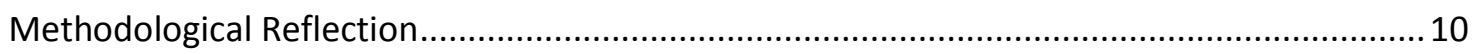

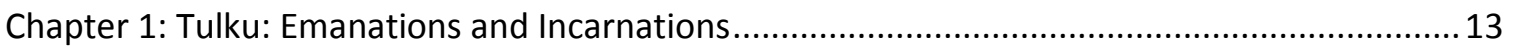

Introduction: The Great Miracle of Manifestation ............................................................... 13

Historical Background: The Order of the Ancients \& the Treasure Traditions ......................... 16

Gödem Truchen \& the Establishment of the Northern Treasure Tradition .............................. 21

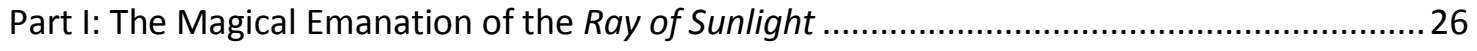

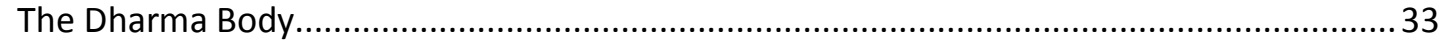

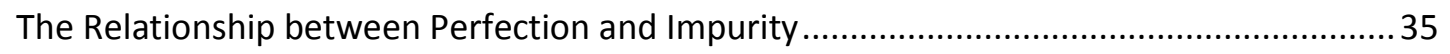

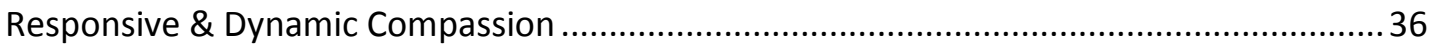

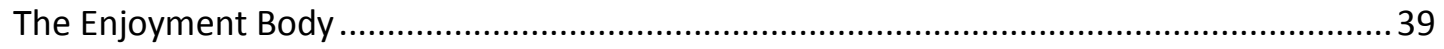

The Manifestation Body: The Magical Emanations of The Ray of Sunlight ........................... 40

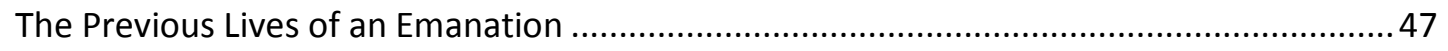

Emanation of Nanam Dorjé Dujom \& Son of Guru Rinpoche .............................................. 50

Section Conclusion: The Magical Emanation of The Ray of Sunlight ......................................53

Part II: The Steadfast Incarnation of The Wondrous Ocean ....................................................56

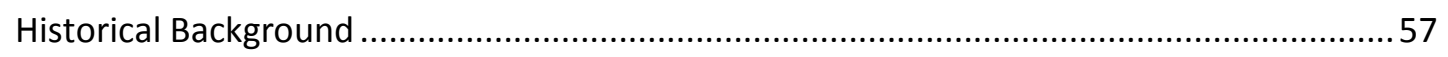

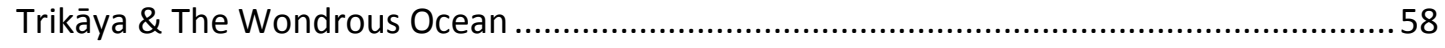

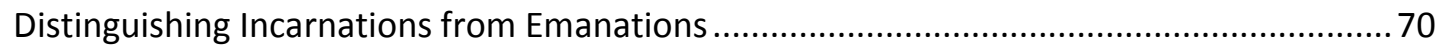

Chapter Conclusions: Incarnation: The Rationalized Emanation.......................................... 74 
Chapter 2: Preincarnations: The Narrative Appropriation of Authority ..................................... 76

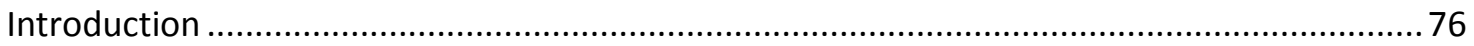

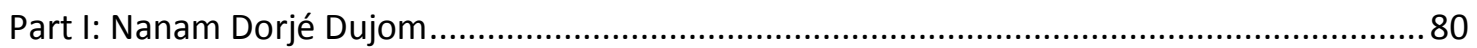

The Ray of Sunlight: A Tradition Bound by Sacred Geography ............................................ 81

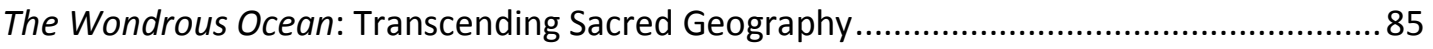

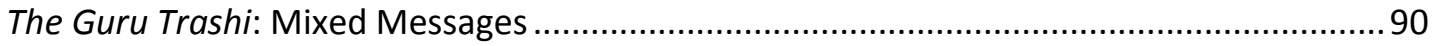

The Contemporary Characterization of Nanam Dorjé Dujom .............................................96

Section Conclusion: The Development of Treasure Authority ......................................... 103

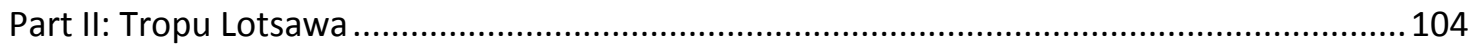

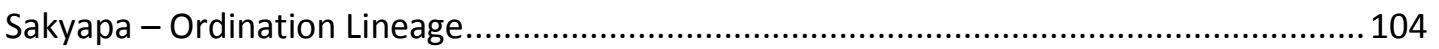

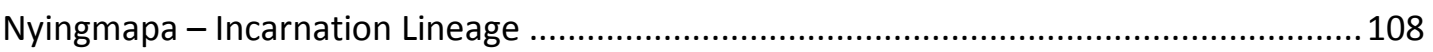

Nyingmapa - Rejection of an Incarnation..................................................................... 111

Nyingmapa - Incarnate Lama \& Treasure Revealer ............................................................. 114

Kagyupa - Uncle-Nephew Lineage \& Sacred Geography ................................................... 118

Chapter Conclusion: The Art of (Re)contextualization \& Appropriation ............................ 127

Chapter 3: Stages in the Development of an Incarnation Lineage \& a Treasure Tradition ..........129

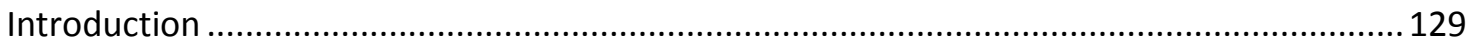

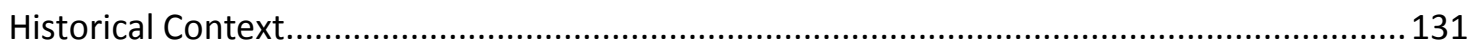

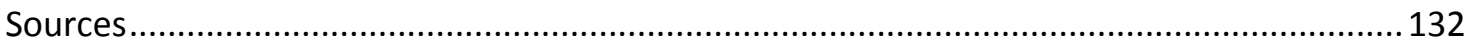

Transmission of Scriptural and Institutional Authority: From Gödem Truchen to Śākya Zangpo $\left(15^{\text {th }}\right.$ c. $)$.....

Recognition of Adults, Karmic Relationships \& Memory: From Śākya Zangpo to the Ngari Brother: Pema Wangyel \& Lekden Dorjé (Mid-16 ${ }^{\text {th }}$ c.) ........................................................ 139

Consenting Adults: Initial Contact with the Northern Treasure Tradition .......................... 139

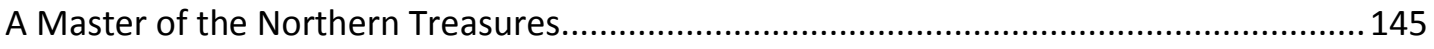

Recognition \& Karmic Relationships between Treasure Revealers ..................................... 148

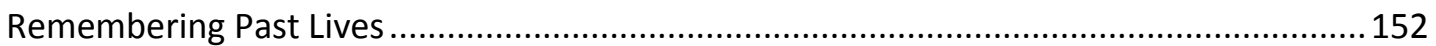

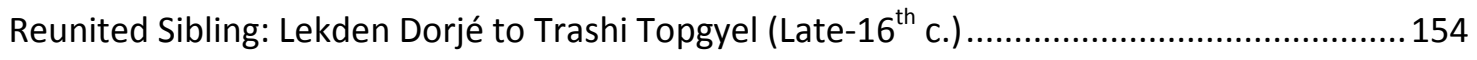

The Brother-Father Regent \& the Incarnate Son: From Trashi Topgyel to Ngakgi Wangpo

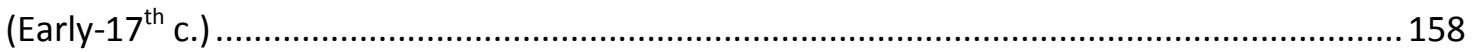

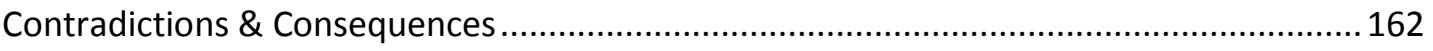

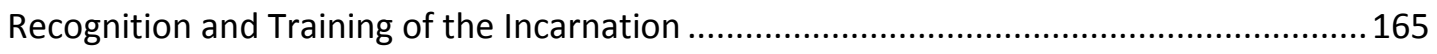


The Foundation of the Community and the Estate 172

Chapter Conclusion: The Development of an Incarnation Lineage

Chapter 4: Recognition, Enthronement \& the Web of Karmic Relationships in the Life of Pema

Trinlé 183

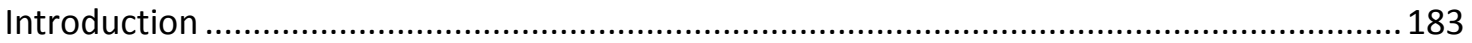

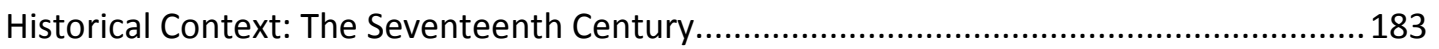

A Brief Account of the Life of Pema Trinlé (1641-1717) ................................................... 185

The Regent \& the Ascension of an Incarnation Lineage .................................................... 187

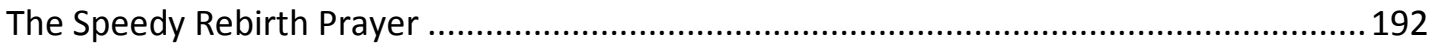

The Family of an Incarnate Lama: Benefits \& Developments.............................................. 196

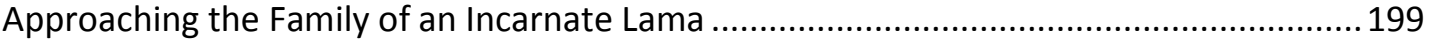

Informal Recognition \& Vetting the Candidate ................................................................. 200

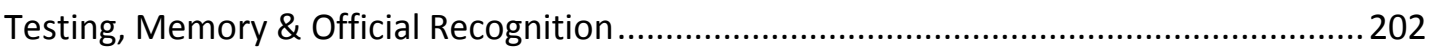

Enthronement, Symbolic Passage \& Departure from the Family .......................................2204

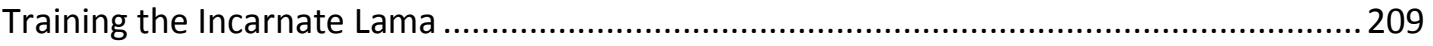

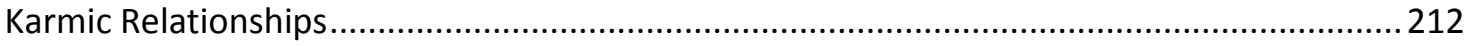

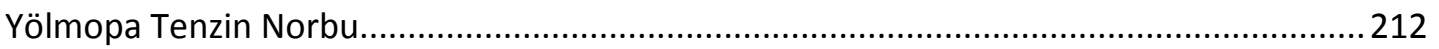

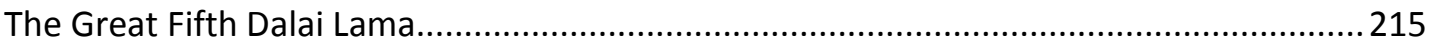

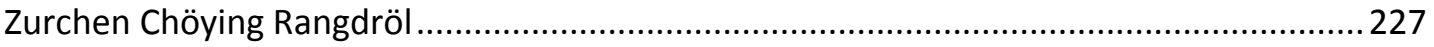

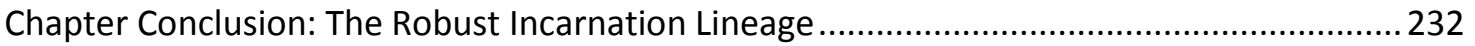

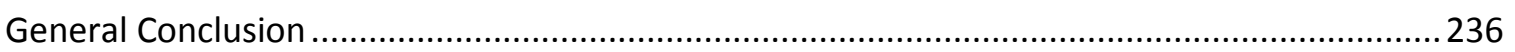

Magical Emanations, Steadfast Incarnations \& Rule by Incarnation .......................................... 236

The Development of the Northern Treasure Tradition \& Methods of (Re)Contextualization and

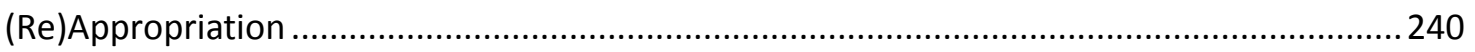

Future Direction for the Analysis of Rule by Incarnation ..................................................... 241

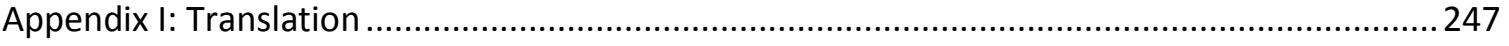

The Clear White Mirror: The Autobiography of Pema Trinlé ..............................................247

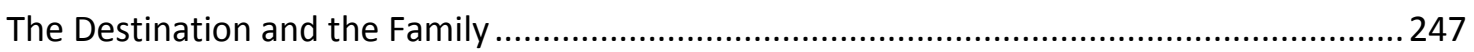

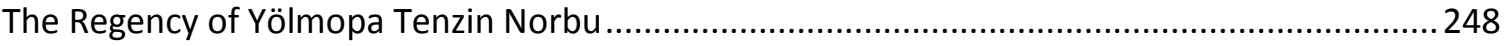

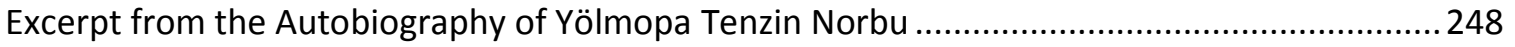

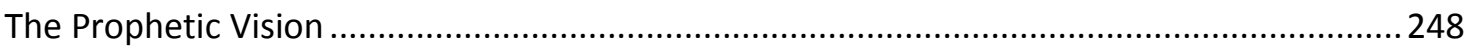

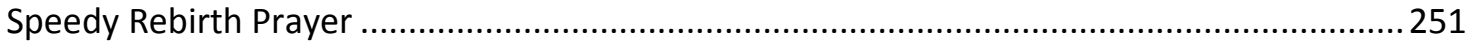




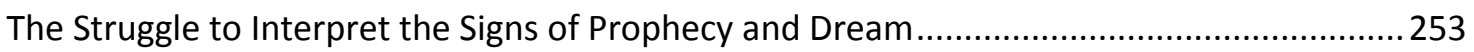

A Letter Expressing Zurchen Chöying Rangdröl's Interpretation......................................... 255

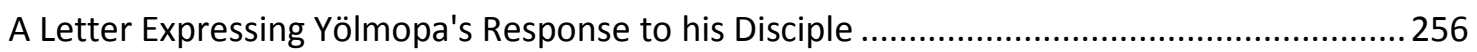

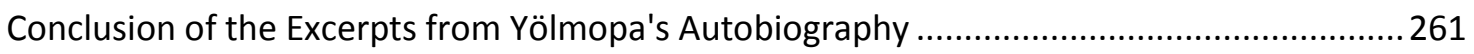

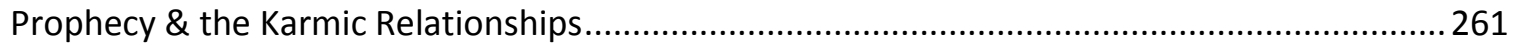

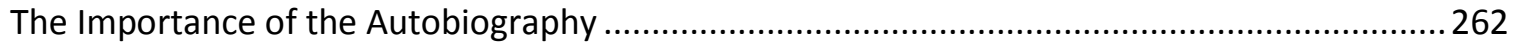

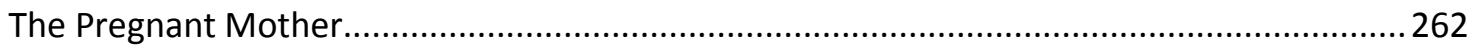

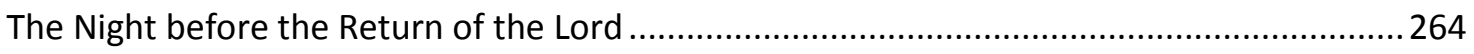

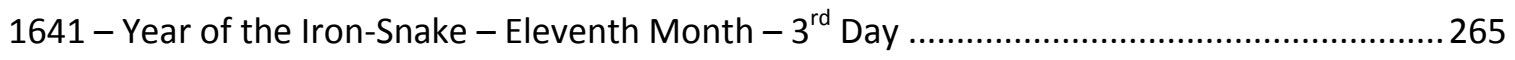

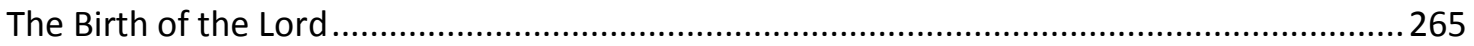

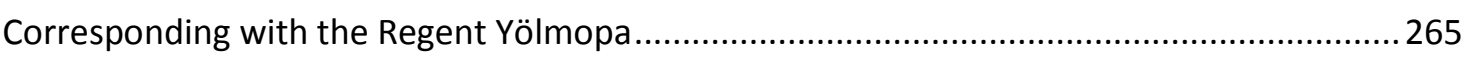

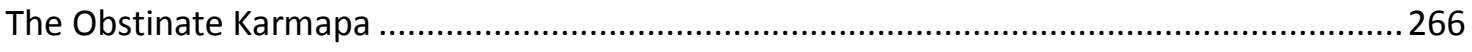

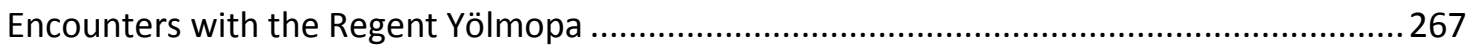

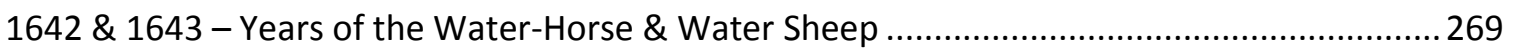

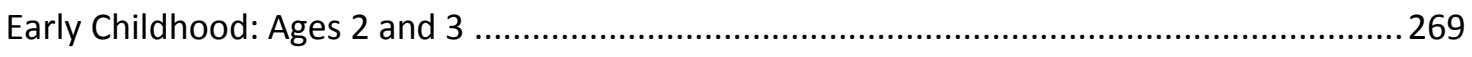

Early Non-Sectarian Training: Dechen Chökhor \& Kongpo Nyipuba ..................................... 270

Yölmopa Initiates the Official Recognition Process ............................................................ 271

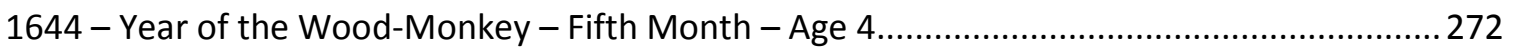

The Official Letter of Recognition \& Enthronement Request ................................................ 272

The Passing of the Regent Yölmopa \& the Recognition Process .............................................2 273

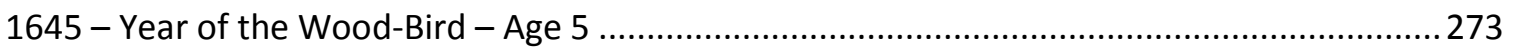

Transmissions from Kongnyön Heruka Lhatsün Namkha Jikmé ........................................... 273

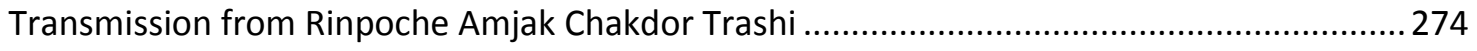

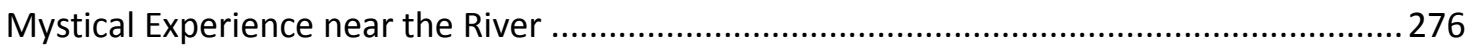

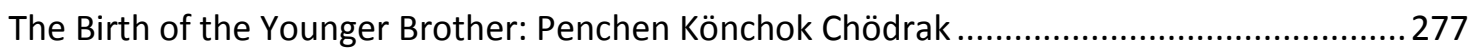

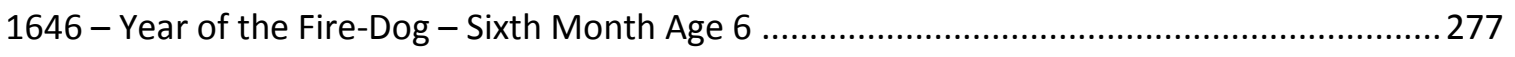

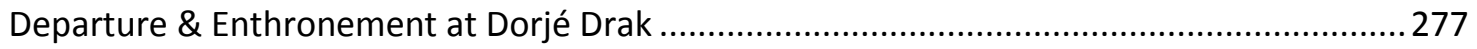

Journey to Lhasa to be Tonsured by the Fifth Dalai Lama ..................................................... 279

Training in Etiquette and Literacy \& the Family of a Young Incarnate Lama .......................... 282

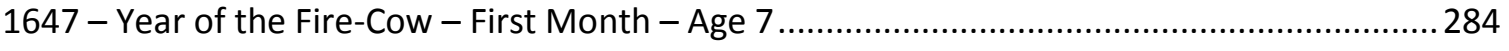

Karmic Connections with Lord Zurchen Chöying Rangdröl \& Others ..................................... 284

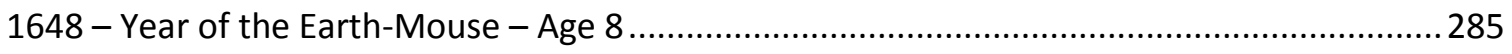


Strengthening the Relationship with Lord Zurchen \& a Death in the Family ......................... 285

Renovations and Consecration at Dorjé Drak ................................................................... 287

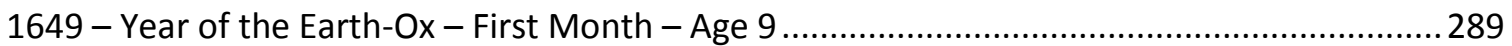

Empowerments from the Great Fifth Dalai Lama at the Potala ..........................................289

Karmic Connection with Kagyurwa Jamgön Sönam Chokden ................................................ 291

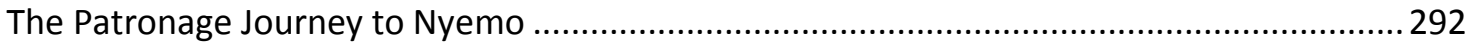

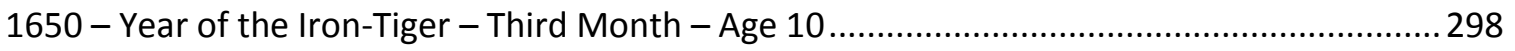

Receiving Transmission from the Fifth Dalai Lama in Lhasa .............................................. 298

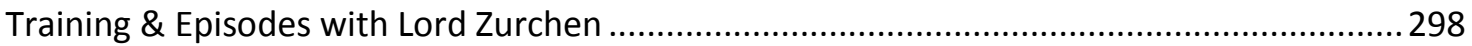

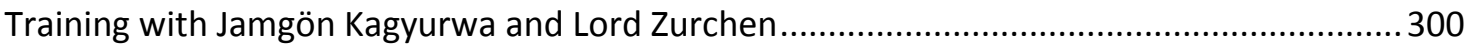

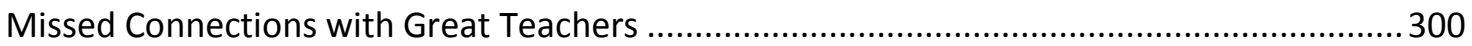

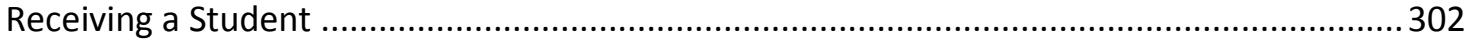

Lord Kongnyön and the an Audience with the Artifacts........................................................ 302

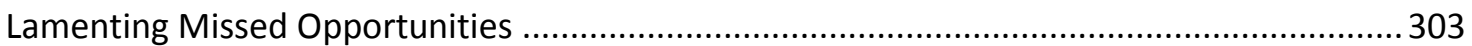

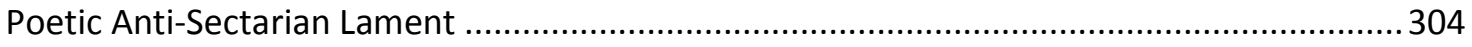

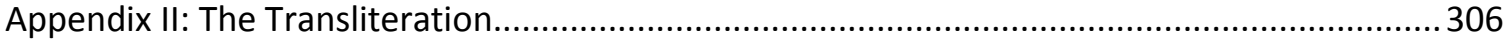

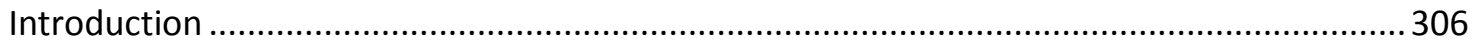

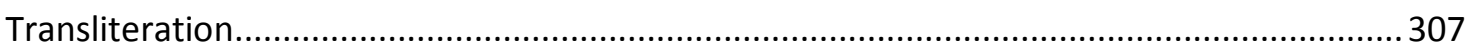

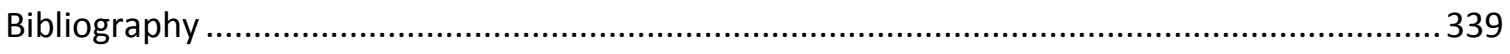

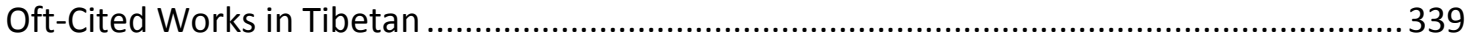

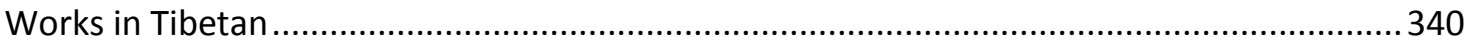

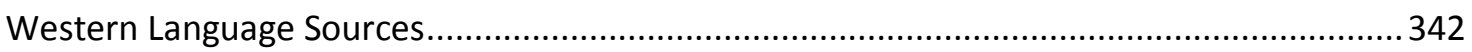




\section{Acknowledgements}

It would not have been possible to have completed this dissertation without the help, support, and influence of many individuals. More than a dozen years have passed since that day when my wife, Catherine Valentine, and I agreed that I should pursue an academic career in the study of Buddhism with the intention of teaching religious studies courses at a college or university. It has been and continues to be an arduous journey that has only been possible because of her unwavering support throughout the years.

I would also like to express my sincere appreciation to my dissertation advisor, Kurtis Schaeffer, for directing me toward this challenging but singularly fascinating (auto)biographical study of the Lords of the Northern Treasures. It is this genuine enthrallment with the subject that has propelled me through the often still waters of my passage. I am also greatly indebted to both Kurtis Schaeffer and David Germano for the endowment of knowledge and skills that I have received from them through seminars and translation courses that focused on Tibetan Buddhism and the Tibetan language. These two professors are also greatly appreciated for their eternal patience, which in my mind has always been the most important virtue of the six pāramitās.

I am also greatly indebted to Lobsang Tashi for his help reading the autobiography of Pema Trinlé in India during my fieldwork. Despite the fact that he humbly requested that I do not formally acknowledge his assistance, his aid translating those sections of the biography that were set within his own stomping grounds in Tibet was invaluable. I will always treasure the look of happy surprise in his eyes when he realized that the prophetic vision of the regent Tenzin Norbu described a landscape that he surveyed himself as a youth in Tibet. 
I would also like to express my deep appreciation of my friend and colleague, Chris Bell. In addition to being an excellent companion and kindred spirit in Charlottesville, Lhasa, and Chicago, he has a genuinely helpful nature and has come to my aid many times in recent years. He has purchased books for me in Tibet, connected me to a wealth of digital resources, guided me through a series of computer frustrations, and has generously shared his own translation work with me. Benjamin Bogin also deserves my appreciation, for it is through his efforts that both the key manuscripts of Pema Trinlé's autobiography were made available to me. He, in fact, scanned the entirety of the alternative version of the text-over 1,000 images—and sent them to me as attachments because he knew that I was beginning to work on the text.

All of the following professors are significant influences to whom I am greatly indebted. If there is one place that can be considered the harbor from which my journey began, it is clearly the World Religions classroom belonging to Alan Fox at the University of Delaware in 1992. It was in that classroom that I developed a lifelong fascination with the religions of the world and Buddhism in particular. Alan has continued to support and encourage me throughout the entirety of my academic and professional voyage. I would also like to thank all of my professors at Naropa University, where I developed a strong foundation in Buddhist theology. Reginald Ray, Judith Simmer-Brown, Sarah Harding, and Philip Stanley each influenced and challenged me in their own unique manner. I thank them in particular for pushing me in equal proportion to my aspirations and for continuing to maintain the character and vision of Naropa University.

There are many professors at the University of Virginia that have been instrumental in my development. Although he has moved on to another university, 
Nicolas Sihle significantly transformed my understanding of Buddhism, as well as religion in general, in his anthropology courses through intense exposure to ethnography and ethnology. I am also greatly thankful for Benjamin Ray's instruction in the methodology of religious studies as well as his guidance through the methodology comprehensive exam. I thank Karen Lang for her instructions in Sanskrit as well as in Indian Buddhism. John Nemec is greatly appreciated for his guidance through the study of Hinduism as my secondary religion of study and for his help in the job application process. Paul Groner is particularly appreciated for his instruction in Daoism and Confucianism; his influence has been apparent every semester that I have had the pleasure of teaching these two religious traditions. I am also very thankful that both Paul Groner and Anne Kinney agreed to be a part of my dissertation committee and I am grateful for their input and direction.

Lastly, I would like to thank those who have made my graduate work financially possible. I received a generous package from the religious studies department at the University of Virginia that supplied me with funding for all of my tuition and health insurance needs. The religious studies department also helped me to acquire generous funding - the Foreign Language and Area Studies (FLAS) Fellowships-from the Center for South Asian Studies. I also travelled to Tibet with the aid of the East Asia Center's Weedon Travel Grant. I again thank my wife, Catherine Valentine, in this context, for she truly is the mastermind and helmsman that has guided our financial ship through the unpredictable financial winds of the past decade. These exploits will certainly receive attention in her future hagiography. 
There are surely many others that have significantly helped me throughout the years, and I apologize for not mentioning you here. To all of my friends, family, teachers, and colleagues, thank you for your support. 


\section{Principle Personages}

\section{The Lords of the Northern Treasures (Tibetan Incarnations)}

$\begin{array}{lll}\text { Phonetic Rendering } & \text { Transliteration } & \text { Dates } \\ \text { Nanam Dorjé Dujom } & \text { sna nam rdo rje bdud 'joms } & \left(8^{\text {th }} \mathrm{c} .\right) \\ \text { Tropu Lotsawa } & \text { khro phu lo tsA ba } & (1173-1225) \\ \text { Gödem Truchen } & \text { rgod kyi ldem 'phru can } & (1337-1409) \\ \text { Jamyang Lama } & \text { 'jam dbyangs bla ma } & \left(14^{\text {th }} \mathrm{c} .\right) \\ \text { Lekden Dorjé } & \text { legs ldan rdo rje } & (1512-1625) \\ \text { Ngakgi Wangpo } & \text { ngag gi dbang po } & (1580-1639) \\ \text { Pema Trinlé } & \text { pad }+ \text { ma 'phrin las } & (1641-1717)\end{array}$

Incarnations of the Brother Lineage

Phonetic Rendering

King Trisong Detsen

Pema Wangyel

Trashi Topgyel
Transliteration

khri srong lde btsan

pad +ma dbang rgyal

bkra shis stobs rgyal

\section{Dates}

(742-796; r. 756-796)

$(1487-1542)$

(1550-1603)

\footnotetext{
${ }^{1}$ An analysis of these problematic dates for the life of Lekden Dorjé appears in Chapter
} Three. 


\section{Incarnations of the Yölmopa Masters}

Phonetic Rendering

Gö Pema Gungtsen

Śākya Zangpo

Namkha Gyajin

Tenzin Norbu
Transliteration

'gos pad ma gung btsan

shAkya bzang po

nam mkha' brgya sbyin

bstan 'dzin nor bu

\section{Dates}

( $8^{\text {th }}$ c. $)$

$\left(15^{\text {th }}-16^{\text {th }} \mathrm{c}.\right)$

(16 $\left.{ }^{\text {th }} \mathrm{c}.\right)$

(1589-1644) 


\section{General Introduction}

The $14^{\text {th }}$ Dalai Lama has captured the imagination of many western observers as a recipient of the Nobel Peace Prize in 1989 and through his continual participation in world politics, science, and religious discourse. Also widely known is the fact that he is not the $14^{\text {th }}$ Dalai Lama in the same way that Saint Victor was the $14^{\text {th }}$ Pope of the Catholic Church or Franklin Pierce was the $14^{\text {th }}$ President of the United States. Although the lineage of the Dalai Lamas is intimately linked to the institutional leadership of a religious organization as well as a national government, it is not simply an office that can be occupied by any individual with a particular set of qualifications. Quite to the contrary, the $14^{\text {th }}$ Dalai Lama is the current incarnation or rebirth of a series of personalities stretching back to the $15^{\text {th }}$ century and beyond. When a Dalai Lama passes from this life, his successor is not selected by a group of cardinals or through a general election; trusted devotees search for his reincarnation and identify him as the next Dalai Lama. After years of rigorous training, the young acolyte takes on the responsibilities of the previous incarnations, which can include the transmission of essential teachings, the management of real estate holdings, and the preservation of important political relationships. This strategy for maintaining institutional authenticity and stability is the uniquely Tibetan institution of rule by incarnation or the tulku system. ${ }^{2}$

\footnotetext{
${ }^{2}$ For the sake of diversity, I also refer to instances of this social institution as incarnation lineages. Although this term can also be employed to denote to a series of concatenated
} 
We find ourselves at a pivotal moment in history as the transition from the $14^{\text {th }}$ to the $15^{\text {th }}$ Dalai Lama will occur on the international stage. The world will watch the drama unfold on cable news stations as the torch is passed from one incarnation to the next. The $14^{\text {th }}$ Dalai Lama himself has already made several controversial statements regarding his own reincarnation, including the ideas that there may no longer be a need for another Dalai Lama and that if he does reincarnate, it may be as a woman. There are also storm clouds on the horizon that indicate that officials within the Chinese government intend on identifying the Dalai Lama on their own, which will likely lead to a scenario that involves two individuals claiming to be the $15^{\text {th }}$ Dalai Lama. With such events lurking in our future, it is an ideal time to engage in an examination of this complex Tibetan institution.

\section{A Case Study of an Incarnation Lineage: The Lords of the Northern Treasures}

Although the incarnation lineage of the Dalai Lamas is the most widely known and has been the focus of many excellent studies, it is far from being the only example of this social institution in Tibetan history. ${ }^{3}$ The incarnation lineage of the Gyalwa

incarnations that is not involved in institutional succession, I employ the term herein with reference to the system of rule by incarnation unless otherwise stated.

${ }^{3}$ A few examples of studies dedicated to the examination of the Dalai Lamas are: Martin Brauen, ed. (2005), The Dalai Lamas: A Visual History (Chicago, Serindia Pub.), Aris, 
Karmapas, for example, is generally maintained as the first known case of a robust incarnation lineage that has included the element of institutional succession since the thirteenth century. ${ }^{4}$ This system for determining institutional leadership proliferated, however, during the sixteenth and seventeenth centuries and produced an elite culture of incarnate lamas that sat upon the thrones of the most powerful monastic institutions of the era. $^{5}$

Michael Aris (1989), Hidden Treasures and Secret Lives (London and New York: Kegan Paul International); Kurtis R. Schaeffer (2006), "Ritual, Festival and Authority under the Fifth Dalai Lama." In Power, Politics, and the Reinvention of Tradition: Tibet in the Seventeenth and Eighteenth Century Tibet: Proceedings of the International Association for Tibetan Studies, Xth Seminar, Oxford University, 2003. Kurtis R. Schaeffer and Bryan J. Cuevas, Editors. (Leiden: Brill Pub.), 187-202.

${ }^{4}$ For a brief account of the origins of the Gyalwa Karmapas lineage, see Geoffrey Samuel (2012), Introducing Tibetan Buddhism (New York: Routledge), 144-146. For a broader view of the incarnation lineage, see: Nik Douglas and Meryl White. ed. (1976), Karmapa: The Black Hat Lama of Tibet (London: Luzac \& Company Ltd).

${ }^{5}$ Geoffrey Samuel, Introducing Tibetan Buddhism (New York: Routledge, 2012), 144150. In this short introductory passage, Samuel asserts that the social institution of rule by incarnation began in the thirteenth century, but was not widely adopted for another three to four hundred years. 
Because of the ubiquitous nature of the phenomenon, it is not possible to systematically examine the histories of each incarnation lineage within the limits of this study. The subject matter is approached below, therefore, through a case study of one particular series of incarnations: Nanam Dorjé Dujom $\left(8^{\text {th }}\right.$ c.), Tropu Lotsawa $(1173-$ 1225), Gödem Truchen (1337-1409), Lekden Dorjé (1512-1625), Ngakgi Wangpo (15801639) and Pema Trinlé (1641-1717). ${ }^{6}$

Within this study, I refer to this collective as the Lords of the Northern Treasures. ${ }^{7}$ Although today the living tradition refers to the incarnations of this series as the Awareness-Holders of Dorjé Drak Monastery (rig 'dzin rdo rje brag), this appellation reflects a later stage in the historical development of the order. ${ }^{8}$ It only adequately

${ }^{6}$ For easy reference, there is a list of the Tibetan incarnations of the Lords of the Northern Treasures and several other important personages on page xii-xiv. There is also a lengthy list of pre-Tibetan incarnations that are discussed in Chapter Three.

${ }^{7}$ For the sake of variety, this series of incarnations is also referred to as the Northern Lords or simply the Lords.

${ }^{8}$ For a recent self-representation of the Northern Treasure Tradition, see: Kunzang Drödül Dorjé (kun bzang 'gro 'dul rdo rje) $\left(18^{\text {th }}-19^{\text {th }}\right.$ c.). thub bstan rdo rje brag dgon gyi byung ba mdo tsam brjod pa ngo mtshar bai DU r+ya'i phreng ba. TBRC W00KG03797. 1 vols. [s.1.]: [s.n.], 2004. http://tbrc.org/link?RID=W00KG03797. 
describes the final two incarnations that are examined herein. All but one of these figures, however, can be sufficiently described as Lords of the Northern Treasures. ${ }^{9}$

\section{Intersecting Institutions: Treasure Revelation \& Rule by Incarnation}

The primary goal of this dissertation is to examine the development of one particular instance of rule by incarnation that involves the Northern Lords, but it is difficult to conduct this study without also exploring the development of the Northern Treasure Tradition itself. ${ }^{10}$ Not a single member of this collective can be reduced in

${ }^{9}$ As will be discussed in more detail below, Nanam Dorjé Dujom is involved in the concealment of the treasures. Gödem Truchen is the primary revealer of the scriptures that provide the focal point of the tradition's identity. All of the subsequent personalities are reincarnations of Gödem Truchen and wielders of the Northern Treasures. Tropu Lotsawa is the only incarnation that does not have an obvious connection to this theme. Evidence is presented in Chapter Three that demonstrates that his membership in the collective is tenuous.

${ }^{10}$ This situation is not unique to the Northern Lords. The institution of rule by incarnation is always maintained in conjunction with a number of other religious institutions that possess their own legitimization strategies, such as ordination, scriptural transmission, family inheritance and so forth. 
significance to his status as a reincarnated lama. ${ }^{11}$ While each of the Northern Lords inhabits a unique intersection of overlapping traditions (e.g., kama, terma, ordination, etc.), the most relevant for this study is the Northern Treasure Tradition (byang gter). No matter how one comes to understand the nature of the Lords (i.e., as emanations, incarnations, or highly developed reincarnations), the notion that any of these individuals is something other than a lowly human arises first as part of the legitimization strategy of the Northern Treasure Tradition in the fourteenth and fifteenth centuries. I will demonstrate below that although some elements are present beforehand, a robust system of rule by incarnation is not fully instituted in this tradition until the seventeenth century. The development overlaps with the tradition's adoption of the monastic platform. Nevertheless, the Northern Treasure Tradition continues to be maintained as the core component of the identity of the incarnation lineage, just as the practice of the corresponding ritual cycles continues to distinguish the religious community of the Dorjé Drak Monastery from the other Nyingmapa monastic institutions.

Therefore, while treasure revelation and the tulku system are indeed two distinct religious institutions, in the case of the Northern Treasure Tradition, they are inextricably intertwined as the latter develops within the former. Thus, while setting out to present a detailed account of the rise of the tulku system within a particular tradition, this dissertation also weaves a complex tapestry that draws attention to important

\footnotetext{
${ }^{11}$ While each of the Tibetan incarnations in this lineage is male, there is more than one Indian incarnation that is female. See Chapter One for details.
} 
developments within the Northern Treasure Tradition itself. The information about this treasure tradition's foundations also offers further insight into the wider developmental trends of the treasure traditions in particular and the Nyingmapa in general.

\section{Preview of Chapters}

The organizational goal of this dissertation is to present and analyze the development of the Lords of the Northern Treasures from the fourteenth through the seventeenth centuries in four thematic chapters. The central figure of the first chapter is Gödem Truchen (1337-1409 CE), the treasure revealer whose revelations form the scriptural backbone of the Northern Treasure Tradition as well as supply it with the anchor for its identity. The primary goal of the investigation is to critically examine the shift in meaning of the term "tulku" (sprul sku) as the system of rule by incarnation develops within the tradition. I argue that in the legitimization strategies that are present in the earliest biography of Gödem Truchen, the term tulku is best translated as "magical emanation" and continues to reflect its Indic origins while also showing influence by the Great Perfection literature. In the later biographical sources that present the Northern Lords as a concatenated series of reincarnated patriarchs, however, the same term is best translated as "steadfast incarnation" to reflect its central place within the system of rule by incarnation and the implicit changes in trikāya theory.

In order to facilitate the primary argument of the chapter, an early selfrepresentation of this treasure tradition is drawn from the earliest biographical sources of the Northern Treasure Tradition. I argue that the legitimization strategies that are apparent from this perspective are primarily concerned with establishing Gödem Truchen as an authentic revealer of scriptural treasures and that there is little evidence to suggest 
that the social institution of rule by incarnation has materialized at this point in the development of the tradition. Nevertheless, even at this early stage, there are significant references to trikāya theory and serial incarnation, and we are thus given the opportunity to examine how these theories are used to serve the legitimization strategies of the institution of treasure revelation.

The second chapter explores two different figures, Nanam Dorjé Dujom $\left(8^{\text {th }} \mathrm{c}.\right)$ and Tropu Lotsawa $\left(12^{\text {th }}-13^{\text {th }}\right.$ c.), who are often championed as the Tibetan incarnations of the lineage that preceded Gödem Truchen. The investigation of these two personalities is guided by an analysis of the many ways in which hagiography is employed as a tool for securing the authority of the charismatic figures of the past for purposes relevant in the continuously unfolding present. In particular, Nanam Dorjé Dujom and Tropu Lotsawa are revealed as the Northern Treasure Tradition's access points to the authority of the Early and Later Propagation of Buddhism to Tibet. Nanam Dorjé Dujom also emerges as the representative of the Northern Lords that was present at the time when the quintessential scriptures of the tradition where concealed.

A key observation that is yielded through a comparison of the earlier and later biographical sources is that for the early tradition, treasure revelation is intimately linked to a particular time (the degenerate age of the fourteenth century), place (the kingdom of Mangyül Gungtang), and purpose (the preservation of the ill-fated kingdom). All three of these parameters are transcended by the later tradition that has relocated its epicenter to Central Tibet and is guided by a series of steadfast incarnations that has been present throughout the history of Buddhism in India and Tibet.

The third chapter focuses on the patriarchs of the Northern Treasure Tradition of the fifteenth and sixteenth centuries. Central to the investigation is the argument that all 
of the patriarchs of this period must be considered in order to develop a more critical view of the Northern Treasure Tradition of this time. Thus, in addition to concentrating on Gödem Truchen's reincarnations, Lekden Dorjé and Ngakgi Wangpo, we must also examine the patriarchs that maintained the tradition between them. These figures include Śākya Zangpo $\left(15^{\text {th }}-16^{\text {th }} c.\right)$, Pema Wangyel (1487-1542), Trashi Topgyel (1550-1603), and Tenzin Norbu (1589-1644). The resulting perspective calls into question the centrality of the Northern Treasures within this tradition that maintained a wealth of kama and terma transmissions. It also forces us to reconsider the position of the Northern Lords among the entire group of patriarchs that includes representatives of other incarnation lineages. I will also argue in this chapter that while the process of reincarnation and serial incarnation are involved in matters of succession, they do not displace the importance of blood relations until the mid-seventeenth century. Moreover, the process of becoming an incarnate lama for the patriarchs of the Northern Treasure Tradition, which at times involves the recollection of one's past lives, is still largely oriented toward treasure revelation in the sixteenth century.

The fourth chapter compliments the preceding through an examination of the incarnation lineage in its robust form. Now we discuss the transition of the largely family-based lay tradition into a monastic institution that exhibits the robust characteristics of the tulku system. The resulting institution is later known as Dorjé Drak, one of six "mother monasteries" of the Nyingmapa, four of which proliferated in the seventeenth century. It is only in this later stage of development that the now commonplace processes of recognition and enthronement are adopted by the Northern Treasure Tradition. The investigation primarily focuses upon the exploits of the tradition's first bona fide regent, Tenzin Norbu, and his efforts to find, recognize, and 
enthrone Pema Trinlé as the next incarnate lord of the tradition. Another feature of the robust form that is explored in this chapter is the presence and importance of "karmic relationships," complex associations with other incarnation lineages that persist through many centuries. Thus, this chapter concludes with a close investigation of Pema Trinlé's relationships with his regent, Tenzin Norbu, his benefactor, Lozang Gyatso (1617-1682) (i.e., the Fifth Dalai Lama), and the teacher that reunites him with the Northern Treasures, Chöying Rangdröl (1604-1669).

The goal of the conclusion is to pull together all of the theoretical and historical findings of the previous chapters. From this vantage point, I am able to offer a final interpretation and analysis on the institution of rule by incarnation. The dissertation concludes with a series of analytical questions that are intended to guide future studies and provide a foundation for comparative analysis.

\section{Methodological Reflection}

It would be easy to interpret the following analysis of the incarnate Lords of the Northern Treasures as an attempt to reduce this distinctive form of religious succession to a strategy for legitimizing authority. It will be immediately evident that Max Weber is among my principle theoretical influences; I frequently interpret the development of incarnation lineages, for example, through the analytical theme of the routinization of charismatic authority. Surely, most of my attention is indeed dedicated to the historical development of the power structure of this unique incarnation lineage. Moreover, there can be little doubt that the character of this Tibetan phenomenon results from the employment of various theories of incarnation and reincarnation to solve the universal human problem of maintaining institutional stability. As will be demonstrated in the 
pages that follow, whether one's vantage point is theological or sociological, incarnate lamas are inherently concerned with continuing the potency and authenticity of their decidedly social agendas.

Nevertheless, it is also completely unnecessary to make a judgment one way or the other regarding the "truth" of incarnation or reincarnation. On the one hand, Tibetan incarnate lamas themselves have been known to express reservations regarding the legitimacy of their own recognition. Despite the fact that these claims have often been interpreted by observers as rhetorical expressions of humility, it is difficult for me to believe that there aren't some Tibetans that are skeptical regarding, at the very least, the precision with which incarnations arrive and are identified. On the other hand, reincarnation is generally accepted as true in Buddhist cultures around the world. In the Tibetan context in particular, there are so many incarnate lamas that are clearly accepted and revered as legitimate reincarnations that there is no need to question the sincerity of the belief in the social institution. As academic observers, we may feel compelled to emphasize some perspectives and ignore others. Some have expressed the opinion that treating historical figures as extraordinary beings deprives them of their rich human qualities and obscures our understanding of these figures as social beings. There is certainly a measure of wisdom in that position. It is also the case, however, that incarnate lamas are treated socially as if they really are reincarnations of previous Tibetan personalities, and this ontological status-real or imagined-directly affects their function as authoritative successors of their own social institutions. In my own calculations, therefore, it is difficult and perhaps counterproductive to separate the rich theological definition of incarnation from the equally colorful sociological analysis. 


\section{Chapter 1: Tulku: Emanations and Incarnations Introduction: The Great Miracle of Manifestation}

Lhasa, circa 1939

On the $15^{\text {th }}$ day of the first month of the year, the Dalai Lama emerges from his majestic palace with a grand monastic entourage and traverses the short distance to the most sacred temple in Tibet. Having ascended to a throne before an expansive audience on this holiest day of the New Year celebrations, the Dalai Lama commemorates the Buddha's defeat of the heretics at Śāvasti in a contest of miracles. ${ }^{12}$ This sacred holiday reminds people that just as the founder of Buddhism wielded his spiritual powers to vanquish the detractors of the dharma in India, the Dalai Lamas employ their own majesty to overcome adversaries and maintain spiritual and temporal order in Tibet.

While the symbolic meaning of this religious holiday is indeed fascinating, it is the nature of the miracles performed by the Buddha in this epic battle that is of interest herein. When Siddhartha Gautama was challenged to a magical duel, he did not call upon the destructive energies of the earth in the form of an earthquake or a flood. Neither did he turn water into wine, cure the sick or walk upon the waters of the ocean. Instead, he filled the sky with a multitude of magically emanated duplicates of himself. ${ }^{13}$ The copies

\footnotetext{
${ }^{12}$ Hugh Edward Richardson (1993), Ceremonies of the Lhasa Year (London: Serindia Publ.).

${ }^{13}$ John S. Strong (2001), The Buddha: A Short Biography(Oxford: Oneworld), 107-112.
} 
were not mere holograms capable only of performing a few limited actions and repeating stock phrases; each Buddha was an independently existing individual capable of making his own decisions. They zipped around in all directions with their own agendas and in full possession of their faculties.

This miracle of multiplicity is just one of the many episodes in the life of the Buddha that calls into question the nature of "buddhahood" itself. Here it would be natural, for example, to wonder which one of the Buddhas is the real Buddha. If each one of them was an autonomous individual-in whatever sense that is possible in Buddhism-how could the difference between the real Buddha and his copies be determined? Within the broad context of Mahayana Buddhism, the answer is that there is no significant difference between them. Both the physical manifestation of the historical Buddha as well as the duplicates he generated at Śrāvasti can be considered "tulku" (sprul sku), or emanations of enlightenment that are experienced by earthly sentient beings.

The concept of tulku, which is nirmāṇa-kāya in Sanskrit, went through many stages of development in India and was later imported to Tibet as part of a refined group of concepts that together explain the nature of buddhahood. In order to translate the word nirmāṇa-kāya into Tibetan, however, terms were employed that were already in use in pre-Buddhist literature to describe, for example, the supernatural or magical production 
of offspring by gods in early Tibetan creation myths. ${ }^{14}$ Today, the term also refers to the Tibetan patriarchs and matriarchs that return in reincarnated form to the same estates life after life in order to continue managing their personal affairs and furthering their Buddhist agendas.

Many have observed that there is an obvious shift in meaning of the term tulku from its earlier ontological to its later sociological usage. ${ }^{15}$ This first chapter is dedicated to the identification and analysis of this perceived change as it appears in the hagiographic literature of the Northern Treasure Tradition. This augmentation of the meaning of the term is apparent in this biographical literature because the doctrine of trikāya was originally employed in this tradition to support the authenticity of its foremost treasure revealer, Gödem Truchen, and the scriptures that he recovered. It is only in the later biographical literature that we find that the concept of nirmāna-kāya has been augmented and employed to buttress the authenticity of an incarnation lineage. I argue that these sources demonstrate that there is a fundamental shift in the meaning of nirmāṇa-kāya from "magical emanation" in the context of the early Northern Treasure

14 R. A. Stein (1973), "Un ensemble sémantique tibétain: créer et procréer, être et devenir, vivre, nourrir et guérir." Bulletin of the School of Oriental and African Studies XXXVI (1973): 412-423.

15 Benjamin E. Bogin (2005), The life of yol mo bstan 'dzin nor bu: A critical edition, translation, and study of the memoirs of a seventeenth-century tibetan buddhist lama. (Ph.D. diss., University of Michigan), 2-3. 
Tradition to "steadfast incarnation" in the context of the later tradition that embraces the institution of rule by incarnation. These translation choices are intended to reflect the fact that serial incarnation is not essential to the characterization of Gödem Truchen in the early sources, while it is featured prominently in the later sources.

Although the primary goal is to analyze the subtleties of the concept of nirmānakāya as it is employed in these two biographical sources in order to gain insight into the development of the institution of rule by incarnation within this tradition, the investigation also offers an opportunity to examine the relationship of serial incarnation and treasure revelation. After examining evidence from the twelfth century, I argue that while trikāya is systematically employed to authenticate treasure revelation, the case of Gödem Truchen demonstrates that the application need not involve serial incarnation. Nevertheless, when serial incarnation is present in these early sources, it is intended to provide a link between the circumstances of concealment and revelation and is not specifically related to the institution of rule by incarnation.

\section{Historical Background: The Order of the Ancients \& the Treasure Traditions}

The Order of the Ancients, which is commonly known as the Nyingmapa (rnying ma), is a diffuse set of traditions that is unified through its transmission of lineages of teachings and practices that were established during the Early Propagation of Buddhism in Tibet $\left(7^{\text {th }}-9^{\text {th }}\right.$ c. $)$. Tradition maintains that the monastic and tantric teachings of the Buddha took firm root during this period of imperialism under the auspices of a series of great Tibetan monarchs such as Songtsen Gampo $\left(7^{\text {th }}\right.$ c. $)$, Trisong Detsen $\left(8^{\text {th }}\right.$ c. $)$, and Ralpachen $\left(9^{\text {th }} \mathrm{c}.\right)$. As the Tibetan Empire began to fragment in the late ninth century, support for institutionalized monasticism eroded. The formulation of Buddhism that 
survived this period of fragmentation relied upon hereditary tantric ritual specialists for its continuity. ${ }^{16}$ These preservers of early Tibetan Buddhism are described as aristocratic clansmen that trace their ancestry to the golden age of the imperium. The Eight Pronouncements (sgrub pa bka' brgyad) is a paradigmatic example of the type of tantric lineage that was maintained by these proto-Nyingmapa traditions. ${ }^{17}$ It is a collection of eight ritual cycles that is significant more for its pragmatic than soteriological applications. Each of the eight employs tantric ritual technology to access a different powerful deity.

Despite the tenacity of the hereditary practitioners that were able to preserve a living Buddhist tradition in Tibet through its period of political fragmentation, their efforts were not universally appreciated. The criticism of these early traditions was part of the impetus that led to and drove the Later Propagation of Buddhism in Tibet that begins in the late tenth century. During this period of time, many Tibetans were driven to reestablish connections with Buddhist masters on the Indian subcontinent, importing the teachings of the Buddha from the founder's homeland anew. The major religious traditions that were established during the ensuing Buddhist renaissance were successful for a variety of reasons, including their reliance upon the institution of monasticism and their adoption of more robust tantric traditions that featured soteriological methodologies. It is within this historical context that these younger traditions distinguish themselves as

\footnotetext{
${ }^{16}$ Geoffrey Samuel (2012), Introducing Tibetan Buddhism (New York: Routledge), xi.

${ }^{17}$ Geoffrey Samuel (2012), Introducing Tibetan Buddhism (New York: Routledge), 34.
} 
the Sarmapa (gsar ma pa) or "New Schools" and the traditions that trace their heritage back to imperial Tibet are grouped together as the Nyingmapa (rnying ma pa) or "Old Schools."

In addition to all of the other challenges that the Nyingmapa traditions were facing at the time, the authenticity of their scriptural heritage was openly attacked. ${ }^{18}$ Within the recently established value system of the new schools, scriptures were only trustworthy if it could be demonstrated that the Tibetan texts were translations of actual Indic source material. The adherents of the old schools were not able to offer this support for their scriptural traditions that often survived in only fragmentary form. Moreover, their corpus also contained scriptures that were authored by Tibetans and therefore could not be proven authentic within the emerging value system. ${ }^{19}$

Retrospectively, the uniquely Tibetan institution of treasure revelation is understood as an effective response to these challenges that plagued the Order of the Ancients during the Later Propagation. ${ }^{20}$ Rather than accepting that authenticity could only be established through a direct and immediate connection with Indian sources, the

${ }^{18}$ For a thorough description of the difficulties faced by the Order of the Ancients at this time, see: Ronald M Davidson (2005), Tibetan Renaissance: Tantric Buddhism in the Rebirth of Tibetan Culture (New York: Columbia UP), 210-211.

${ }^{19}$ For a discussion of problems of authentication, see: Davidson (2005), 215.

${ }^{20}$ It should be noted that there are many important Sarmapa and Bönpo treasures as well. For a discussion of the origins of treasure revelation, see: Davidson (2005), 210-231. 
adherents of the old schools reaffirmed the value of their connection to the golden age of the Tibetan Empire when Buddhism was first established in the Land of Snows. Within this newly developing narrative tradition, a few of the hero-saints of the Early Propagation (e.g., Vimalamitra, Guru Rinpoche, and Vairochana) are understood to have transmitted two distinct sets of teachings. ${ }^{21}$ The first set was appropriately matched to the needs and abilities of the Tibetans that lived during the imperial age. The tantric teachings that were established at that time come to be known as the kama (bka' ma) traditions. Endowed with visionary and prophetic faculties, however, these hero-saints knew the contours of Tibet's destiny and saw that many other teachings would be required in the future. These scriptures were also transmitted during the imperial era, but they were concealed or buried as "treasure" (gter) along with other artifacts that would appropriately meet the unfolding needs of future generations of Tibetan Buddhists.

At some point during the Later Propagation, these treasure texts and artifacts began to be extracted by charismatic "treasure revealers" (gter ston), and the resulting tantric scriptural lineages are known as the treasure traditions. This newly developed religious institution for revealing scriptures grows into an effective means for the Order of the Ancients to continuously update themselves to meet the ever changing challenges of the times. It has been observed, for example, that treasure texts often feature the latest innovations of the time of revelation rather than the time of concealment. Treasure

${ }^{21}$ Davidson (2005), 229. 
revelation, therefore, offers the Nyingmapa a means for developing authentic modernizations without forsaking their imperial heritage.

Although the adherents of the new schools continued to question the authenticity of their scriptures, the redactors of the treasure traditions established alternative strategies of legitimization that did not depend upon a direct and immediate connection to India. Essential to the treasure traditions is a corpus of narrative historiographies, prophecies, and hagiographies that establishes a connection between the circumstances and agents of concealment and revelation. Most of this growing body of narrative literature is also the product of treasure revelation. Despite the apparent circular nature of this form of authentication, the strategy turns out to be quite effective as it eventually produces a coherent narrative that captures the hearts and minds of nearly all Tibetans. As early as the twelfth century, influential historiographies that narrate the most important events of the Early Propagation feature the exploits of Guru Rinpoche and his innermost group of twenty five disciples in the court of King Trisong Detsen $\left(8^{\text {th }} \mathrm{c}\right.$.). As a sign of the success of these narratives, nearly all traditions assert that the concealment of their respective treasures occurred under the auspices of Guru Rinpoche. The authority invested in this figure is so great that he is often referred to as the Second Buddha.

Nevertheless, the authenticity of the treasure revealers themselves is also an important element of the legitimization strategies that are mobilized through this narrative tradition. In the revealed prophetic literature, Guru Rinpoche offers details about the individuals who will reveal the treasures in future times. In the hagiographic material, including both biography and autobiography, the authors confirm that the prophesized events actually occurred in the life of the treasure revealer. This connection between the prophetic and the biographic literature is an essential factor in determining 
the legitimacy of a treasure revealer. Within this narrative tradition, the language of trikāya theory is often employed to describe the elevated ontological status of Guru Rinpoche and the treasure revealers.

\section{Gödem Truchen \& the Establishment of the Northern Treasure Tradition}

The treasure revealer whose revelations form the scriptural backbone of the Northern Treasure Tradition is Gödem Truchen (rgod kyi ldem 'phru can) (1337-1409). Because his treasures were extracted from the holy mountains of what was then known as the region of Jang (byang), a term that alone means "north," the resulting scriptural tradition is referred to as the Jangter (byang gter) or the Northern Treasure Tradition to distinguish it from traditions established in other places and times. Gödem Truchen's homeland lies about one hundred miles west of the city of Zhikatsé in Tsang (gtsang), which is also nearly three hundred miles west of the city of Lhasa (lha sa) in Central Tibet (dbus). ${ }^{22}$

The following summary of the early history of the Northern Treasure Tradition is largely drawn from the Ray of Sunlight, which is the earliest known biography of Gödem Truchen that was written by one of his immediate disciples, Nyima Zangpo (nyi ma

${ }^{22}$ For a more detailed description of the region, see: Jurgen Wilhelm Herweg (1994), The Hagiography of Rig 'dzin Rgod kyi ldem 'phru can and Three Historical Questions Emerging from It (M.A. thesis, University of Washington), 16-20. 
bzang po) $\left(14^{\text {th }}-15^{\text {th }}\right.$ c. $) .^{23}$ The intention is to characterize the nature of the tradition as it was represented in the early fifteenth century, shortly after the passing of Gödem Truchen.

Gödem Truchen was born as Ngödrup Gyeltsen (dngos grub rgyal mtshan) within a family of tantric practitioners that upheld the values of the Order of the Ancients. His father, Lopon Sidu Dulpa (slob dpon srid bdud 'dul dpal), was an accomplished master of the royal Degyin Hor (de gyin hor) clan that had been associated with the imperial Tibetan courts since its arrival from Mongolia in the early eighth century. ${ }^{24}$ The clan is known for its transmission of early Gyuntrül (sgyu 'phrul), Vajrakīla (phur bu ze'u), Mamo (ma mo), and Great Perfection (rdzogs chen bram ze'i) lineages. ${ }^{25}$ Because his father dies while he is very young, Gödem Truchen primarily receives these kama transmissions from his uncles. In fact, Gödem Truchen is surrounded by clansmen throughout his life as his parents, wife, uncles, children and nephews are all active participants in the family enterprise.

${ }^{23}$ Nyima Zangpo (nyi ma bzang po) $\left(14^{\text {th }}-15^{\text {th }}\right.$ c.), "sprul sku chen po'i rnam thar gsal byed nyi ma'i 'od zer (ga)," In byang gter lugs kyi rnam thar dang mang 'ongs lung bstan. TBRC W27866. : 53-152. (Gangtok, Sikkim: Sherab Gyaltsen and Lama Dawa, 1983). Mentioned throughout as The Ray of Sunlight.

${ }^{24}$ Nyima Zangpo (nyi ma bzang po) $\left(14^{\text {th }}-15^{\text {th }}\right.$ c.), The Ray of Sunlight, 58-59.

${ }^{25}$ He receives the "rdzogs chen bram ze'i" transmission of the Great Perfection from his father. 
Even before he reveals his own set of treasure scriptures, Gödem Truchen modernizes his own practice through the incorporation of the treasures of Guru Chöwang (gu ru chos kyi dbang phyug) (1212-1270), which he received from Nangden Gyelpo (snang ldan rgyal po) in his early twenties (c. 1360). ${ }^{26}$ Gödem Truchen's own treasure career was likely inspired by what he learned about treasure through the works of Guru Chöwang. ${ }^{27}$ He must have also, therefore, been acquainted with the treasures of Nyangrel Özer (nyang ral nyi ma 'od zer) $\left(12^{\text {th }} \mathrm{c}\right.$.), for he is the previous incarnation of Guru Chöwang and is featured prominently in his biographies. Although Longchenpa (klong chen pa) (1308-1363), the great redactor of the Seminal Heart transmission, is not mentioned in the early biographical literature, Gödem Truchen does receive additional training in the Great Perfection from one Draklungpa Khetsün Rinchenpel (brag lung pa mkhas btsun rin chen dpal) prior to beginning his own career as a treasure revealer. ${ }^{28}$

${ }^{26}$ Nyima Zangpo (nyi ma bzang po) $\left(14^{\text {th }}-15^{\text {th }}\right.$ c.), The Ray of Sunlight, 68.

${ }^{27}$ For a study of Guru Chöwang, see: Janet Gyatso, (1994), "Guru Chos-dbang's gTer 'byung chen mo: an early survey of the treasure tradition and its strategies in discussing Bon treasure." Occasional Papers - Institute For Comparative Research In Human Culture I(I): 275-287.

${ }^{28}$ For an explanation of the origins of the Seminal Heart tradition of the Great Perfection and Longchenpa, see: Janet Gyatso and David Germano (2000), "Longchenpa and the Possession of the Dākin̄̄." In Tantra in Practice. David Gordon White. ed. (Princeton: Princeton University Press), 239-265, 243-245. 
At the age of thirty (c. 1367), Gödem Truchen indirectly receives a collection of treasure literature that had recently been revealed by the deceased Ritröpa Zangpo (ri khrod pa bzang po) $\left(14^{\text {th }}\right.$ c. $) .{ }^{29}$ After acquiring these materials, which included directions for extracting future treasures, Gödem Truchen reveals several large cashes of scriptures and artifacts from the sacred mountains of Jang. Foremost among these treasures is the Gongpa Zangtel (dgongs pa zang thal), which is an extremely important Great Perfection text, and the Vajrakīla cycle, which is essential to the identity of the tantric masters of the Northern Treasure Tradition. ${ }^{30}$ Although the biography does not appear to be concerned with defending itself from external criticism, the acceptance of the authenticity of these revealed scriptures also legitimize their preexisting kama correlates. ${ }^{31}$

Throughout Gödem Truchen's career as a treasure revealer, he is often preoccupied with securing the patronage of the monarchs of Mangyül Gungtang (mang

${ }^{29}$ Nyima Zangpo (nyi ma bzang po) $\left(14^{\text {th }}-15^{\text {th }}\right.$ c.), The Ray of Sunlight, 84-90.

${ }^{30}$ For a study of the Zangtel, see the forthcoming dissertation of Katarina Turpeinen, University of Virginia. For a study of the Vajrakîla, which also discusses the other treasures discovered by Gödem Truchen, see Martin Boord (1993) The Cult of the Deity Vajrakila: According to the Texts of the Northern Treasure Tradition of Tibet (Byanggter phur-pa). (Tring: The Institute of Buddhist Studies).

${ }^{31}$ For a discussion of the legitimizing power of terma, see: Ronald M. Davidson (2005), Tibetan Renaissance: Tantric Buddhism in the Rebirth of Tibetan Culture. (New York: Columbia UP), 216. 
yul gung thang), a kingdom that continued until 1620 and was located immediately southwest of Jang. ${ }^{32}$ The royal family of Mangyül Gungtang traced its heritage back to the great monarchs of the Tibetan Empire and in many ways represented the last of the surviving remnants of the imperium. One of the implicit arguments that Nyima Zangpo threads throughout the biography is that the patriarchs of the Northern Treasure Tradition, a group that includes himself, have a rightful claim to the patronage of the Mangyül court. Moreover, the destiny of the kingdom is intimately linked to Northern Treasures because they were buried in the lands north of the kingdom by Guru Rinpoche for the express purpose of aiding the monarchs in dark times.

Gödem Truchen and his uncles establish a practice center at Mount Trazang in Jang (c. 1370), which is the site of one of his treasure revelations. After his passing (c. 1409), Mount Trazang continues to act as the epicenter of the Northern Treasure Tradition for several generations. ${ }^{33}$ Throughout this time period, the tradition is guided by a series of patriarchs that are nearly all members of the same clan and thus the tradition

${ }^{32}$ For an extensive study of the Gungtang Kingdom, see Per K. Sørensen (2007), Rulers on the Celestial Plain (Wien: Verl. Der Österr. Akad. Der Wiss).

33 Tradition maintains that the seat of the Northern Treasure Tradition was relocated at Dorjé Drak by Trashi Topgyel (1550-1603). I argue below that while it is clear that Trashi Topgyel relocated his family practice to central Tibet, it is not entirely clear that this meant an end to activities at Mount Trazang, which is still active in the late seventeenth century. 
continues to maintain the values of the Order of the Ancients. From this point forward, however, the practitioners maintain a blend of kama and terma tantric transmissions. While the tradition has supplied itself with an authentic set of scriptures that allow it to compete against the New Schools, it has done so without embracing the institution of monasticism. ${ }^{34}$ It is important to acknowledge that the Northern Treasure Tradition, as well as the institution of treasure revelation and the school of the Order of the Ancients, continues to develop and transform long after this moment in the early fifteenth century.

One of the elements of the Northern Treasure Tradition that will later undergo significant transformation involves the ontological nature of Gödem Truchen as a treasure revealer. Throughout the biographical literature, he is represented as an exalted individual and is described using the terminology of trikāya. In the following pages, I argue that despite this uniformity, the representation of his exalted ontological nature in the biographic literature undergoes significant transformation.

\section{Part I: The Magical Emanation of the Ray of Sunlight}

The nature of the historical Buddha and his enlightened disciples (arhat) after they have exited cyclic existence has always been a subject of interest for Buddhists. If the self of the Buddha that had been adrift on the ocean of samsara were nothing more than a collection of aggregates held together by karma, just as a raft is a collection of tree trunks

\footnotetext{
${ }^{34}$ In Chapter Four, the further transformation of the Northern Treasure Tradition into a monastic institution is discussed in more detail.
} 
held together by a rope, then how can we speak of him after the rope of karma has been untied and the logs of his body have been scattered? Is the Buddha completely extinct, as the term nirvana suggests, and therefore absent, or is he somehow still present and available for his followers? These questions are not trivial as the very first act of declaring oneself a Buddhist is to take refuge in the Buddha. How are we to understand this declaration if the Buddha is completely and utterly gone?

The situation is further complicated with the appearance of a host of celestial buddhas in the Mahayana Sutras. Akṣobhya, Amitābha, and Vairochana are among those that are championed in the new scriptures. These buddhas generate and abide in their own celestial realms and each is involved in guiding humans toward enlightenment in his own way. The celestial buddhas themselves become essential figures in a host of later Buddhist pathways from Tantric to Pure Land Buddhism. Although the celestial buddhas are more available than Śākyamuni Buddha and the arhats, their wondrous nature is no less baffling for those struggling to comprehend the nature of buddhahood itself.

The general strategy employed in the various formulations of the multi-body theories of buddhahood is to recontextualize the physical body of the historical Buddha as a mere earthly manifestation of a more fundamental body of realization. This strategy shifts the focus from the nature of the Buddha after he has departed from cyclic existence to the nature of the Buddha before he took earthly form. While it is accurate, therefore, to say that his human personification has completely dissolved, the more fundamental source that expressed itself as the Buddha of our world persists and continues to manifest for the benefit of sentient beings.

A similar strategy is employed in this first excerpt from The Ray of Sunlight that explains the ontological nature of Gödem Truchen using trikāya. The passage begins by 
expressing the grand extent of this saint's power, but quickly turns to the more difficult task of placing this manifestation of enlightenment within the larger Buddhist context.

This precious lama [Gödem Truchen] matures and liberates all sentient beings whose numbers are immeasurable like the expanse of the sky by means of his treasure-wheel [of teachings], which is ornamented by the inexhaustible body, speech, mind, qualities and activities of all the [Buddhas] that have gone forth in the ten directions and the three times.

Immeasurable eternities ago in the past, he achieved buddhahood as the glorious Samantabhadra and desiccated the miserable ocean of cyclic existence by employing the twenty five attributes of fruition, including his free and realized [mind]. As for the story of his liberation in that life, even if the victors of the three times were to narrate it for one hundred eternities, they would not complete the description of even one of his good qualities.

How could beings [like us], who see only the near side of things, even expect to fathom [his depths]? Nevertheless, there is an adage that says that if you were to look at the sky through a hole [in the ceiling], it would appear to have color and shape. [If we were to express it], therefore, in a way that is understandable to those of us with devotion but limited perspectives, [we would say that] there is the Dharma Body (chos sku), and without any movement within this unborn state, there [appears] the pure Enjoyment Body (long sku) and the impure Manifestation Body (sprul sku). Thus, [we can say] that [Samantabhadra] 
appears as an inconceivably large number of manifestations to act for the benefit of migratory beings. ${ }^{35}$

${ }^{35}$ Nyima Zangpo (nyi ma bzang po) $\left(14^{\text {th }}-15^{\text {th }}\right.$ c.), 51-52. The work of Jurgen Herweg initially brought my attention to The Ray of Sunlight by way of his excellent M.A. thesis. It should be noted that the translations that appear in this dissertation are based on the primary source of the biography, not Herweg's thesis. Jurgen Wilhelm Herweg (1994), The Hagiography of Rig 'dzin Rgod kyi ldem 'phru can and Three Historical Questions Emerging from It (M.A. thesis, University of Washington). Transliteration: 51.2 phyogs bcu dus gsum gyi de bzhin gshegs pa thams cad kyi sku gsung thugs yon tan phrin las mi zad pa brgyan gyi 'khor lo'i mdzod kyis nam mkha' dang mnyam pa'i sems can thams cad smin pa dang grol 'dra mdzad pa'i bla ma rin po che 'di ni/_sngon bskal pa dpag tu med pa'i sngon rol du/_dpal kun tu bzang por sangs rgyas shing/_spangs rtogs sogs 'bras chos nyer lngas/_khor ba sdug bsngal gyi rgya mtsho skems pa'i rnam thar ni/_dus gsum gyi rgyal bas/_bkal ba brgyar 52 brjod kyang/_yon tan sna gcig gi phyogs tsam brjod pas/_rdzogs par mi nus na/_tshu rol mthong ba'i skye bos bsam pa'm/_dpag par ga la nus/_on kyang bu kha'i nam mkha' la dbyibs dang kha dog brjod pa'i dpes/_rang mos gus kyi mig chung ba rnams kyi snang ngor go tshul la/_chos sku skye ba med ngang las ma g.yos par/_dag pa long sku/_ma dag pa sprul sku/_de las yang sprul bsam gyis mi khyab par snang nas 'gro ba'i don mdzad de/_ 
This passage confirms that Gödem Truchen was endowed with the qualities of Buddhahood. His wondrous attributes, however, were not the karmic consequences of actions performed in a sequence of lives leading up to the present, but they were instead expressions of an enlightened state that was achieved in a primordial time by the Buddha Samantabhadra. The relationship between this buddha that abides outside the normal boundaries of time and space and the manifestations of his enlightenment that are perceivable by the lowly beings of this world is not something that can be explained using our limited forms of language. Nevertheless, within the context of Buddhism and Buddhist scholarship, this relationship can be explained provisionally using the trikāya theory.

This description of Gödem Truchen's ontological nature is a mirror image of the later Mahayana descriptions of Śākyamuni Buddha. It is revealed in that context that it was actually the bodhisattva named Śvetaketu that achieved full enlightenment in Tuṣita heaven. Śākyamuni was simply a magical emanation issuing forth from the enlightened Śvetaketu for the sake of sentient beings still trapped within cyclic existence. ${ }^{36}$ His appearance on earth was a magical manifestation that engaged in an educational drama that included birth, suffering, nirvana, and final parinirvāṇa. This was all, however, appearance for buddhahood in its most fundamental form, the Dharma Body, does not arise, abide, or subside. Thus, the question is redirected toward the source of the

36 Martin A. Mills (2003), Identity, Ritual, and State in Tibetan Buddhism: The Foundations of Authority in Gelukpa Monasticism (London: RoutledgeCurzon), 99. 
Buddha's manifestation, rather than the location of an illusion after it has vanished. On the surface, it appears that the version of trikāya that is expressed in The Ray of Sunlight closely follows the dominant Indian Mahayana formulation of trikāya that was imported to Tibet.

The Three Bodies of the Buddha

English Translation

1) The Dharma Body

2) The Enjoyment Body

3) The Manifestation Body ${ }^{37}$
Sanskrit

Dharmakāya

Saṃbhogakāya

Nirmāṇa-kāya
Tibetan (Wylie)

chos sku

long sku

sprul sku

There is evidence, however, that the tradition of employing trikāya theory to describe the exalted status of hero-saints in the treasure traditions had already been established by the time Nyima Zangpo authored The Ray of Sunlight in the early fifteenth century. In the early biographies of Nyang-rel Nyima Özer $\left(12^{\text {th }} \mathrm{c}.\right)$, this treasure revealer is continuously described as a nirmāṇa-kāya manifestation of enlightenment. ${ }^{38}$ Similarly,

37 Central to the argument of this chapter is that nirmāna-kāya should be translated differently depending on the context. I employ the term "Manifestation Body" as a neutral alternative when speaking in general terms.

${ }^{38}$ For a recent study of Nyang-rel's early biographies, see: Hirshberg (2012). Therein, nirmāṇa-kāya is translated as "magically emanated reincarnation." Daniel A. Hirshberg 
Guru Rinpoche is also defined as a nirmāṇa-kāya throughout The Copper Palace (rnam thar zangs gling ma), which was revealed by Nyang-rel and is the earliest biography of Guru Rinpoche that recasts him as the central hero-saint of the Tibetan imperium as well as the institution of treasure revelation. ${ }^{39}$

Guru Chöwang $\left(13^{\text {th }}\right)$ is also described as a nirmāṇa-kāya in the early biographic material. ${ }^{40}$ Therein, Guru Rinpoche informs Guru Chöwang in a visionary experience that despite the absence of the physical signs of enlightenment that adorned the body of Śākyamuni, he is actually a nirmāṇa-kāya. ${ }^{41}$ This statement follows on the heels of Guru Rinpoche's delineation of three different aspects of nirmāṇa-kāya; Guru Chöwang is the third type that can manifest in a variety of shapes and forms in order to tame sentient

(2012) Delivering the lotus-born: Historiography in the tibetan renaissance (Ph.D. diss., Harvard University), 83.

${ }^{39}$ For an English translation of The Copper Palace, see: Ye-śes-mtsho-rgyal $\left(8^{\text {th }} \mathrm{c}.\right)$, The Lotus-born: The Life Story of Padmasambhava. Revealer. Nyang-rel Özer (nyang ral nyi ma 'od zer) $\left(12^{\text {th }}\right.$ c.). Trans. Erik Pema. Kunsang. Boston: Shambhala South Asia Editions, 1999.

${ }^{40}$ For a detailed description of this subject, see Hirshberg (2012), 74-75.

${ }^{41}$ Guru Chöwang (gu ru chos dbang) (1212-1270), "ghu ru chos dbang gis rnam mthar bka' rgya brgyad ma." In gu ru chos dbang gi rang rnam dang zhal gdams, vol. 1. 65-151. (Paro: Ugyen Tempai Gyaltsen, 1979.), 108-109. 
beings. While there may have been other treasure revealers that employed trikāya theory in their revelations prior to the fourteenth century, it is safe to assume that Nyima Zangpo had been exposed to the biographies of Nyang-rel and Guru Chöwang and that those texts influenced him while he authored The Ray of Sunlight.

While the model of trikāya that is embraced by Nyima Zangpo closely resembles the Indic formulations, it is also apparent that he has been influenced by trends in the Great Perfection literature that significantly augment the standard formulation. In the following presentation and analysis of trikāya, these elements are identified and explained.

\section{The Dharma Body}

For good reason, the Dharma Body is the most difficult to comprehend. In its most basic form, it can be understood as the sum total of all of the Buddha's teachings. Another formulation asserts that the Dharma Body is the totality of all the Buddha's "good" qualities. ${ }^{42}$ The Buddha's earthly form necessarily had some qualities that were determined by his appearance in cyclic existence. Thus, the Buddha ate, slept, and felt pleasure and pain like everyone else. He also had enlightened qualities, like the ability to perform miracles, which did not originate from his earthly form, but from his Dharma Body. The passage above suggests that if you were to recite the good qualities of

42 Malcolm David Eckel (1992), To See the Buddha: A Philosopher's Quest for the Meaning of Emptiness (San Francisco: HarperSanFrancisco), 99. 
Samantabhadra forever, you would still only be able to mention a small fraction of those good qualities.

The concept of the Dharma Body is further developed, however, to refer to the Buddha's understanding, which ultimately leads to equating the Dharma Body with nondual awareness itself. The primary method of thinking for humans within cyclic existence is based on an artificial division of experience into a perceiving subject and observed objects. The Buddha, however, is able to transcend the bonds of dualistic thinking and open himself to non-dual awareness, which allows him to see the suchness of all things. The Dharma Body is additionally thought of as the "place" or "source" from which good qualities and non-dual awareness originate, but the idea of location is more of a dualistic metaphor intended to aid our understanding and suggest its non-dual correlate.

We thus arrive at the idea that the Buddha is eternal because his primary body is the non-dual awareness of the Dharma Body, which is by definition perfect and unaffected by change and is therefore beyond the boundaries of temporality. Moreover, since the non-dual awareness of all of the Buddhas is the same, then all of the Buddhas are one when viewed from the perspective of the Dharma Body. Within the context of the Order of the Ancients, the Dharma Body (dharmakāya) is represented by Samantabhadra, the primordial buddha (ādibuddha) and the source of all the buddhas and their teachings including the Great Perfection. Following Guru Chöwang's example in the thirteenth 
century, the treasure traditions have continued to use Samantabhadra as a unifying representation of the Dharma Body. ${ }^{43}$

\section{The Relationship between Perfection and Impurity}

Perfection, however, is a doctrinal double-edged sword. It is, of course, always beneficial to claim that your saints are somehow produced from a perfect source because this implies the spiritual and ethical purity of your heroes. The problem is that philosophically speaking "perfection" implies that there is no change and therefore something perfect cannot be the "source" of anything else in the normal sense of the term. If, for example, a small piece of the Dharma Body were to break off and depart for the human realm, then the "perfect" source would be quantitatively diminished and therefore no longer perfect. This is a fundamental philosophical quandary that has been tackled by both Eastern and Western philosophers around the globe.

We are left, then, with explaining how the Enjoyment and the Manifestation Bodies are related to their "source," the Dharma Body. In the excerpt above, we are simply told that the latter two bodies appear separate from the first without any movement occurring within the primordial state of the Dharma Body. The cosmological model is not a form of material causality or creationism, but shares more with the various Western models of emanationism that seek to explain the relationship between a perfect

43 Andreas Doctor (2005), Tibetan Treasure Literature: Revelation, Tradition, and Accomplishment in Visionary Buddhism (Ithaca, NY: Snow Lion Publications), 29. 
first principle and the imperfect manifestations experienced by humanity. It is essentially the ontological correlate to the ethical quandary regarding the existence of evil in a world created by an omnibenevolent god.

The ontological problem is often addressed in the context of the Great Perfection using the metaphor of the sky and the rainbow. The profundity of the Dharma Body is represented by the clear blue, unbounded sky that has no beginning or end. The Enjoyment and Manifestation Bodies are represented by rainbows, which magically appears in the sky for short periods of time but are nonetheless real. Furthermore, although the rainbows could not appear without the sky, there is nothing in the heavens that is diminished through its manifestation. The pure source of buddhahood is not, therefore, polluted as a result of its relationship with the Enjoyment and Manifestation Bodies.

\section{Responsive \& Dynamic Compassion}

Both the Enjoyment and the Manifestation Bodies are often said to be conditioned by two factors. The first, which is not mentioned here, is the vow or vows that were made prior to a buddha's enlightenment. Amitābha, for example, vowed to create a Pure Land as a result of his attainment of nirvana where sentient beings could be reborn and dedicate their lives to Buddhist practice. He could not possess such an intention as a buddha, because both the wholesome and unwholesome types of intentionality are karmic patterns that no longer arise in the fully enlightened mind. The other important factor, which is mentioned at length in the following passage, is the karma or karmic condition of the perceiver. 
In short, [Samantabhadra] appears to the Buddhas as the Dharma Body known as Amitābha. To the bodhisattvas, he appears as the Enjoyment Body known as Avalokiteśvara. To King [Trisong Detsen], his ministers, and the male and female disciples with good karma, he appeared as the Manifestation Body known as Padmasambhava. In the minds of people like me, who are sentient beings of a degenerate age with very little accumulations, he appears in the holy personage of a treasure revealer. But in reality, he is certainly a great being that embodies the body, speech, and mind of all the Buddhas of the three times. ${ }^{44}$

This presentation conforms to the standard Indic model in that enlightenment appears differently in response to the conditions of the observers. However, the formulation is clearly influenced by the narrative logic of the treasure traditions. Not only is Guru Rinpoche identified as a nirmāṇa-kāya, his status within that category is elevated through his association with the golden age of the Tibetan Empire and the rule of King

${ }^{44}$ Nyima Zangpo (nyi ma bzang po) $\left(14^{\text {th }}-15^{\text {th }}\right.$ c.), 55-56. Transliteration: nye bar bsdus na/_sangs rgyas rnams la chos sku snang ba mtha' yas/_byang chub sems dpa' rnams la longs sku spyon ras gzigs/_sprul pa'i rgyal blon rnams dang/_las can rnal 'byor pho mo rnams la sprul sku pad+ma 'bung gnas/_bsags pa shin tu chung ba'i snyigs dus kyi sems can/_bdag lta bu rnams kyi blo ngor gang zag dam pa gter ston tsam du snang na ma gtogs/_don gyi ngo bo la dus gsum sangs rgyas thams cad kyi sku gsung thugs kyi bdag nyid chen 56 po yin par thag chod cing/_ 
Trisong Detsen; the purity and power of the emanation matches the purity and the power of the times. In fact, this passage appears to be an elaboration of the four lines of verse that serve as the prologue of The Copper Palace that was revealed in the twelfth century by Nyang-rel:

Homage to the divinities of the three kayas:

To dharmakaya Amitabha,

To sambhogakaya Great Compassion, noble Avalokiteshvara,

And to nirmanakaya Padmasambhava. ${ }^{45}$

Nyima Zangpo's fifteenth century presentation, however, advances this earlier model in two significant ways. First, Samantabhadra is positioned as the primordial source of all three bodies of enlightenment. Second, the treasure revealers are also identified as nirmāṇa-kāya. Although they enjoy the same ontological status as Guru Rinpoche, they are less pure in comparison because they are generated in response to the needs of the unfortunate humans of the degenerate age. Nyima Zangpo did not live during the nearly mythic times of King Trisong Detsen and the establishment of Buddhism in Tibet. He found himself in a degenerate age of increasing darkness in the Land of Snows. In this specific temporal and geographical context, the Manifestation

45 Ye-śes-mtsho-rgyal $\left(8^{\text {th }}\right.$ c.). The Lotus-born: The Life Story of Padmasambhava, Revealer. Nyang-rel Özer (nyang ral nyi ma 'od zer) $\left(12^{\text {th }}\right.$ c.), Trans. Erik Pema. Kunsang (Boston: Shambhala South Asia Editions, 1999), 29. 
Body of Samantabhadra took the form of a treasure revealer named Gödem Truchen. Although he appeared to the beings of the degenerate age in this limited body that experienced birth, suffering, and death, in reality he was an expression of the transcendent enlightenment of the primordial buddha.

\section{The Enjoyment Body}

To the bodhisattvas abiding in the celestial realms, the Enjoyment Bodies (samphogakāya) appear as the celestial buddhas. Here "enjoyment" means "experience" in the way that we might say that one "enjoyed the benefits of society" regardless of whether or not the benefits were actually appreciated or pleasurable. These celestial buddhas can also appear to earth-bound humans through visionary experiences, such as those involving Akṣobhya in the Vimalakīrti Sutra. ${ }^{46}$ Enjoyment Bodies are also an integral part of tantric Buddhism as the practitioner of deity yoga envisions herself as one of these celestial buddhas. ${ }^{47}$

It should also be acknowledged that Amitābha and Avalokiteśvara frequently complement each other in the relationship of Dharma Body to Enjoyment Body, exactly as presented in The Ray of Sunlight and The Copper Palace. For example, Trashi Topgyel (1550-1603) authored a biography of Guru Rinpoche toward the end of his life

\footnotetext{
${ }^{46}$ Robert A. F. Thurman (1988), trans. The Holy Teaching of Vimalakintti. (University Park, Pa.: Pennsylvania State Univ.), 93.

${ }^{47}$ Samuel (2012), 69-71.
} 
that also features this Dharma-Enjoyment Body team. He, however, explicitly refers to Samantabhadra as "the expanse of reality" (chos dbyings; dharma-dhātu). ${ }^{48}$ This implies that Trashi Topgyel was intentionally placing Samantabhadra and Amitābha in separate categories, the latter being the dharma-kaya.

\section{The Manifestation Body: The Magical Emanations of The Ray of Sunlight}

All of the magical appearances of buddhahood within cyclic existence that are perceivable by regular humans are called Manifestation Bodies (nirmāna-kāya), which is translated into Tibetan as tulku (sprul sku). The most famous buddha of them all is, of course, the historical buddha, who is referred to as Sākyamuni Buddha - the buddha who was the sage of the Sākya clan. As mentioned above, by identifying Guru Rinpoche and the treasure revealers as nirmāṇa-kāya, Nyima Zangpo is effectively shaping trikāya to serve the purposes of a treasure tradition.

Nyima Zangpo also continues a trend that appears within the Great Perfection literature of the eleventh century that interprets a much wider range of phenomena as manifestations of enlightenment. ${ }^{49}$ The most important quality of a nirmāṇa-kāya manifestation is that it responds to the needs of sentient beings within cyclic existence, but that is the extent of the limitation.

\footnotetext{
${ }^{48}$ Trashi Topgyel (bkra shis stobs rgyal) (1550-1603) pad+ma 'byung gnas kyi rnam thar. TBRC W8873. 1 vols. (Gangtok: Sherab Gyaltshen Lama, 1976), 2-4.

${ }^{49}$ Davidson (2005), 237-238.
} 
Because of [Samantabhadra's] compassion for those of inferior accumulations, he had no thought of dissolving [from existence after nirvana]. In the fiery hells, he manifested without delay as fresh breezes and coolness. In the freezing hells, he appeared as warmth and heat. To the hungry ghosts he appeared as the thought of being satiated merely by the internal movement of breath. To those who are arrogantly obsessed with maintaining their wealth, he was roused by impermanence to appear as the misfortunes of disease, warfare, and famine. To those who were miserable and very poor, he appeared as a mine of jewels. $\mathrm{He}$ appears as the warmth, rain, and other [environmental factors] that caused the growth of grain. He appeared as the sun, moon, stars, planets, orchards, and forests.

Having appeared [in a forms that experienced] sickness, old age, birth, death and all the other [misfortunes of human existence], he has purified these obscurations [in himself]. Because [sentient beings] are still experiencing these obscurations, he manifests in these ways. Having appeared in such an inconceivably large number of compassionate forms, the mass of sentient beings whose numbers are unfathomable like the height of the sky were liberated from the miserable ocean of cyclic existence. He then established them on the [bodhisattva] stage of liberation and omniscience.

As it is said in the [lam rim],

At times peaceful and at times wrathful.

To the horny, he shows sex. To the haters, he shows hatred.

He will be a mountain for a treasure and the darkness for the dark. 
As [unhindered] as the wind,

his manifestations can adhere to these examples or be discordant.

A proliferation of skillful means as vast as the ocean,

Through enlightened activities like these, he liberates [all].

It is also said in that same text that, "He will even discipline beings using the emanated forms of hunters, prostitutes, and the like." ${ }^{50}$

${ }^{50}$ Nyima Zangpo (nyi ma bzang po) $\left(14^{\text {th }}-15^{\text {th }}\right.$ c. $), 54-55$. Transliteration: bsags pa dman pa rnams la thugs rjes yal bar mi 'dod te/_tsha dmyal gyi gnas su ser bu dang/_bsil la lhang par snang/_grang dmyal la tsha ba dang drod du snang la/_yi dwags rnams la dbugs nang du 'gyus pas 'grangs pa snyam byed pa dang/_longs spyod srung gi rgyags dregs pa rnams la/_mi rtag bskul ba'i phyir nad mtshon mu ge'i skal pa dang/_sdug cing shin tu dbul ba rnams la'ang/_rin po che'i gter dang/_drod gsher la sogs pas lo 'bras bskyed pa dang/_nyi zla gza' skar/_ci shing nags tshal/_na rga skye 'chi la sogs par snang nas sgrib pa sbyong ba dang/_sgrib pa rnams myong bas mdzad pa la sogs/_thugs rje'i rnam 55 grangs bsam gyis mi khyab par snang nas/_nam mkha' dang mnyam pa'i sems can thams cad/_khor ba sdug bsngal gyi rgya mtsho las sgrol cing/_thar pa dang thams cad mkhyen pa'i sa la 'god par mdzad do/_lam rim las/_res 'ga' zhi la res 'ga' drag/_g.yem la g.yem ston sdang la sdang/_gter la ri dang mun la mun/_rlung la'ang de bzhin thun/_mi mthun/_rgya mtsho lta bu'i thab spyod pa'i/_phrin las de bzhin pa yis sgrol/_ces dang/_rngon dang smad 'tshong la sogs pa/_sprul pa'i gzugs kyis 'dul bar bye/_ces so/_ 
The striking element of this passage is that the Dharma Body's manifestations are not limited to taking the form of earthly buddhas. Quite to the contrary, the Manifestation Body can take any form in cyclic existence as it "results from" the meeting of the compassion of Samantabhadra and the karma of the perceiver. Thus, a buddha manifests as all manner of animate and inanimate things from the sun itself to the food that nurtures us. Furthermore, the ethical distinction between wholesome and unwholesome as well as peaceful and wrathful is eradicated as a buddha will cause the appearance of whatever is needed for the individual, even if it is a licentious barmaid. In the end, the Dharma Body turns out to be the ground of all reality itself and is beyond the dualistic thinking that includes the distinction between nirvana and samsara. And, everything that appears is a manifestation of Samantabhadra's compassion and intended to guide one toward enlightenment. This grand soteriological narrative suggests a richer, multi-dimensional functionality of trikāya that is at the heart of the Great Perfection literature.

In order to assess the role of serial incarnation for the early Northern Treasure Tradition, it is necessary to consider further the mechanics of trikāya. The three bodies are often described as operating in sequence so that the Enjoyment Body magically arises from the Dharma Body, and the Manifestation Body in turn arises from the Enjoyment Body. The alternative presentation in The Ray of Sunlight reports that both the Enjoyment Bodies and the Manifestation Bodies emanate directly from the Dharma Body itself. The text does not appear to intentionally limit the abilities of the Enjoyment Body to engender Emanation Bodies, but rather emphasizes the role that the Dharma Body performs as the ultimate source of enlightenment. These are the two simple methods for interpreting the relationship between the various bodies of buddhahood. 


\section{Two Simple Models of Trikāya Mechanics}

1) Dharma Body $\rightarrow$ Enjoyment Body $\rightarrow$ Manifestation Body

2) Dharma Body $\pi_{\text {Manifestation Body }}^{\text {Enjoyment Body }}$

The first of these models is the foundation upon which the later propagators of the institution of rule by incarnation build their biographical traditions. Both of these models are simple enough to describe orderly relationships between the various manifestations of trikāya. From the grand perspective of the Great Perfection that is featured in The Ray of Sunlight, however, practically all phenomena are categorized as nirmāṇa-kāya expressions of enlightenment. Instead of a simple sequence of enlightened manifestations, the perspective yields an expanding web of compassionate enlightenment.

\section{Complex Model of Trikāya Mechanics}

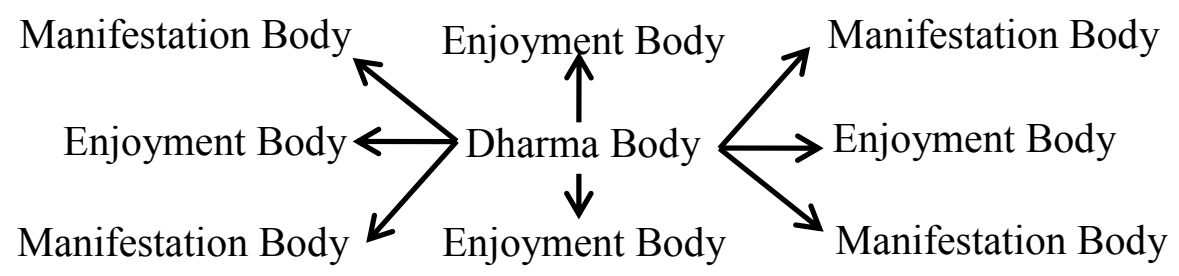

This model is further complicated by the fact that Enjoyment Bodies and Manifestation Bodies can also generate their own web of enlightened manifestations. For 
example, the monkey and the rock ogress that are featured in a popular myth about the origins of the Tibetan people are known to be magical manifestations that were issued forth from Avalokiteśvara and Tara respectively. ${ }^{51}$ As discussed in the introduction to this chapter, Śākyamuni's greatest miracle features the production of enough duplicates of himself to fill the earth and heavens alike. And, these are not anomalous events, for similar occurrences can be found throughout the Mahayana Sutras. From the profound view of The Ray of Sunlight, there is not a single thing within our field of experience that could not be a nirmāṇa-kāya intended to guide us toward enlightenment.

This version of trikāya that is influenced so dramatically by the perspective of the Great Perfection is not designed to easily support the enterprise of tracking the past or future incarnations of a particular manifestation. In the passages that have been presented above, for example, Guru Rinpoche and Gödem Truchen are both magical emanations of Samantabhadra. Notice that this does not imply that Gödem Truchen and Guru Rinpoche should be viewed as possessing the same exact status from the earthly perspective. The emanation that appears as a treasure revealer is a response to a particularly degenerate age, which is inhabited by individuals of little accumulation of spiritual merit. Guru Rinpoche manifested during the golden age of the Tibetan Empire, and his nature matches the exalted character of those times. Furthermore, Nyima Zangpo is not stating

51 Ye-śes-mtsho-rgyal $\left(8^{\text {th }}\right.$ c.). The Lotus-born: The Life Story of Padmasambhava, Revealer. Nyang-rel Özer (nyang ral nyi ma 'od zer) $\left(12^{\text {th }}\right.$ c.), Trans. Erik Pema. Kunsang (Boston: Shambhala South Asia Editions, 1999), 189. 
in any shape or form that Gödem Truchen is a reincarnation of Guru Rinpoche. It is merely establishing that they are both manifestations of the magical splendor of the primordial buddha that somehow remains in meditative equipoise outside of time and space while also appearing in a manifold of inconceivable forms within the ocean of suffering that is our home. Authenticity is determined by the pure nature of the source of enlightened activity. From this perspective, the nirmāna-kāya manifestations that appeared as Guru Rinpoche and Gödem Truchen were not the results of karmic activities performed in a concatenated series of lives leading up to their embodiment as tulku. The notion that either of these nirmāṇa-kāya manifestations will return to earth in human form is similarly irrelevant within this context. The needs of future Tibetans will be met spontaneously by the responsive nature of the dharma-kāya as the web of manifestations continues to unfold. There is little to suggest that any two manifestation bodies should be conceived as joined in a concatenated series any more than Gödem Truchen should be thought of as an incarnation of Guru Rinpoche.

In the context of this model of trikāya that is employed in The Ray of Sunlight, the concept of tulku is best translated as "emanation" or even as "magical emanation" to emphasize the direct relationship between the primordial source of enlightenment and the manifestation. Perhaps the primary concern of this biography is to establish beyond a doubt that Gödem Truchen is a legitimate treasure revealer. As discussed below, Nyima Zangpo employs a variety of conflicting strategies to demonstrate his master's authenticity. Foremost among them, however, is the lengthy description of Gödem Truchen as a magical emanation of the primordial Buddha Samantabhadra, which appears at the very beginning of the biography and employs the language of the Great Perfection, the supreme vehicle of the Order of the Ancients. 
As The Ray of Sunlight is not a philosophical text, but is instead a religious biography, it does not remain constant regarding Gödem Truchen's status as a magical emanation throughout the entirety of the text. One of the reasons that there are so many different views of Gödem Truchen's nature in the text is that the author provides quotations from numerous prophetic sources that evidently have contrasting views. Although the interpretation of Gödem Truchen as a magical emanation is the dominant view of the text and can explain all of the other characterizations, it will be nonetheless informative to examine a few of the apparent counterexamples.

\section{The Previous Lives of an Emanation}

In the following excerpt from The Ray of Sunlight, Gödem Truchen is presented as an individual that has been progressing through a series of lives in the manner that would be expected of normal sentient beings within cyclic existence.

The Prophetic Liberation Story says: [...]

All of the karmic seeds that have been collected for eleven lifespans will come together at that time. The fruit [of these actions] will be a suitable vessel for holding all of the highest teachings. He will be born as a man of either the Year of the Ox or the Dragon. ${ }^{52}$

\footnotetext{
${ }^{52}$ Nyima Zangpo (nyi ma bzang po) $\left(14^{\text {th }}-15^{\text {th }}\right.$ c.), 62.5-63. Transliteration: nam thar lung bstan las/_ [...] 63.2 skye ba bcu gcig nas bsags pa'i sa bon thams cad dus der 'dzom
} 
It should not be overlooked that the primary importance of this passage is that it contains a prophecy regarding the birth of a treasure revealer. Later in the biography we learn that this prophetic utterance accurately describes the circumstances of Gödem Truchen's birth. As mentioned above, the pairing of prophetic and hagiographic material is an essential element of the legitimization strategies of the narrative treasure literature. In isolation or in a different context, one could interpret this passage as an attempt to demonstrate that Gödem Truchen is directly linked to the circumstances of treasure concealment during the Tibetan empire through a series of eleven concatenated lives. As discussed in the conclusion of this chapter, there is already precedence for this legitimization strategy in the treasure traditions. This passage, however, is clearly intended to satisfy the need to prove that the treasure revealer's existence and activities are not circumstantial or contingent, but are preordained as reported in the prophetic literature of the treasure traditions.

The logic contained within this passage is that it is necessary for a sentient being to progress through many lifetimes of maturation before he or she can possibly contain the knowledge that is required of a great treasure revealer like Gödem Truchen. The presence of the karmic seeds of eleven lifetimes would suggest that a treasure revealer's

pas:_'bras bu bla na med pa'i chos thams cad kyi snod du rung ba cig 'byung ste yang glang ngam:_brug gi lo pa zhig gi skye ba len no:_ 
status is something that is achievable by a regular sentient being through the cultivation of one's own karma. Even if we are to consider the possibility that a magical emanation could continue through the folds of life and death without vanishing like an apparition-a view that is maintained by the later propagators of the institution of rule by incarnation, it does not follow that such an expression of enlightenment would actually be developmentally affected by the process through the accumulation of karmic seeds. This is clearly an alternative understanding of Gödem Truchen's nature that conflicts with his status as a magical emanation.

A parallel set of conflicting views are also maintained regarding the nature of Śākyamuni. According to the Mahayana theory of trikāya, the Buddha was a nirmāṇakāya manifestation that was produced by the enlightened essence of Śvetaketu, who achieved buddhahood in Tusita Heaven. From this perspective, he is categorically different than transmigrating sentient beings. Nevertheless, the standard biographies of the Buddha and the stories of his previous lives in the Jătaka Tales work together to express an earlier view that the Victorious One was a normal human that progressed far enough in his previous lives to produce a human body capable of achieving buddhahood. In the case of The Ray of Sunlight, these two conflicting views coexist as they likely do in the minds of many Mahayana Buddhists. Nevertheless, the dominate view of the text is that what characterizes the activity of this primordial buddha is his ability to manifest in any form in any place and at any time in a manner that provides the specific help needed by a specific individual or group of sentient beings. 


\section{Emanation of Nanam Dorjé Dujom \& Son of Guru Rinpoche}

The following excerpt from The Ray of Sunlight is also a quotation from a prophetic treasure text. This passage appears to reflect the view of Gödem Truchen as a reincarnation of Nanam Dorjé Dujom that becomes the norm in the $17^{\text {th }}$ century, but is a peripheral perspective in this text.

A second manuscript says: $[\ldots]$

On the eastern slope of Mount Trazang, Of Nanam Dorjé Dujom

An emanation (sprul pa) named Gödem Truchen

Will arrive in a secret manner possessing compassion.

He will extract three treasuries of scriptures to benefit migratory beings. Endowed with the good karma of keeping his tantric vows.

He will be my, Padmasambhava's, son. ${ }^{53}$

It is tempting to interpret this passage as a clear declaration that Gödem Truchen is an incarnation or reincarnation of Nanam Dorjé Dujom. This would mean that the mind stream of the eighth century royal minister later animated the body of the fourteenth

${ }^{53}$ Nyima Zangpo (nyi ma bzang po) $\left(14^{\text {th }}-15^{\text {th }}\right.$ c.), 79. Transliteration: shog dril gnyis pa las/_ [... 79.3 ri bo bkra bzang shar 'dabs su:_sna nam rdo rje bdud 'joms kyi:_sprul pa rgod kyi ldem 'phru can:_sbas tshul snying rjer ldan pa 'byung:_gter mdzod gsum bton 'gro don byed:_dam tshig can gyi las can de:_pad+ma 'byung gnas bdag gi sras: 
century treasure revealer. While this appears to be a valid interpretation of the passage, it is also possible that the perspective results from the projection of our knowledge of later developments backward in time to texts that predate those developments. Certainly, tradition currently maintains that Gödem Truchen and all of the other Northern Lords are reincarnations of Nanam Dorjé Dujom, who is understood as the link to the concealment of the Northern Treasures. This view, however, is not explicitly articulated in The Ray of Sunlight, it is not clear that Gödem Truchen should be understood as a reincarnation of Nanam Dorjé Dujom—or anyone else for that matter—in this text. While Nanam Dorjé Dujom's ritual dagger and hair are among the artifacts that are concealed at Mount Zang Zang Lhadrak (zang zang lha brag), there are also artifacts that belong to Yeshe Tsogyal and King Trisong Detsen. Moreover, while Nanam Dorjé Dujom appears to be present during the concealment of these treasures, he is only one among three observers and is not singled out as an active participant. The significance of the concealment narrative for Gödem Truchen is that he fulfills a particular prophecy by emanating as a treasure revealer in close proximity to the mountain where the treasures were concealed. His authenticity does not appear to depend upon a link to Nanam Dorjé Dujom, but instead results from his emanational relationship with Samantabhadra that he shares in common with Guru Rinpoche. ${ }^{54}$

An alternative interpretation of this passage is that Gödem Truchen is a magical emanation that issued forth directly from Nanam Dorjé Dujom rather than

\footnotetext{
${ }^{54}$ The importance of Nanam Dorjé Dujom will be revisited in Chapter Two.
} 
Samantabhadra. This is the same type of enlightened activity that Avalokiteśvara employed to produce the monkey co-progenitor of the Tibetan people and Śakyamuni mobilized to defeat the heretics at Śāvasti. It is possible that this process is later understood to be synonymous with serial incarnation.

In search for an alternative interpretation of the passage, my attention has been drawn to the statement at the end that asserts that Gödem Truchen is the "son" of Padmasambhava. It is difficult to imagine how this claim could be interpreted literally, especially since earlier in the text it has been established that both Padmasambhava and Gödem Truchen are emanations of Samantabhadra. Thus, it would be acceptable to understand both of the examined claims of the passage by way of analogy or metaphor. Just as Gödem Truchen is not the biological, but the spiritual son of Padmasambhava, he is not the literal reincarnation of Nanam Dorjé Dujom, but a being that embodies some essential element of his character. The similarities could manifest as physical or intellectual talents, just as a child often excels in the same skills as his or her parents. For example, I will argue in the next chapter that Nanam Dorjé Dujom eventually becomes the archetypal tantric personality of the Northern Treasure Tradition.

Alternatively, the similarity could also manifest through analogous socio-religious activities. It is, for example, tempting to interpret the passage above as suggesting that just as Nanam Dorjé Dujom was the religious minister for King Trisong Detsen, Gödem Truchen will be the religious minister for the Kings of Mangyül Gungtang. This interpretation does make sense, but Nyima Zangpo mentions neither Nanam Dorjé Dujom's role as a religious minister nor his role in the invitation of Guru Rinpoche to Tibet. This is an interesting omission as both facts would strengthen the rather obvious 
argument in the text that Gödem Truchen is destined to enter into a patron-priest relationship with the Kings of Mangyül Gungtang.

Regardless of how the birth prophecy above is interpreted, however, it cannot be overlooked that it appears toward the middle of the biography, which is hardly the place to insert a statement regarding someone's previous rebirth. It is doubtful that Gödem Truchen was considered to be a direct reincarnation of Nanam Dorjé Dujom or anyone else during his lifetime. Even if he was, however, his status as a reincarnation of an eighth century personality is not as important as his status as a magical emanation of Samantabhadra in this early biography.

\section{Section Conclusion: The Magical Emanation of The Ray of Sunlight}

When Nyima Zangpo's masterful biography is considered in its entirety, the interpretation of Gödem Truchen as a magical emanation is the most appropriate as it conforms to the Great Perfection inspired version of trikāya that dominates the landscape of the text. The entire theme of treasure revelation is set within this view of trikāya as Guru Rinpoche and the treasure revealers are identified as nirmāna-kāya expressions of the primordial Samantabhadra. Serial incarnation, while suggested in various passages, is not central to the authority structure of the text and it is doubtful that Gödem Truchen's authority was grounded in such claims during his lifetime. It is more likely that this status was attributed to him at a much later date as the tradition does not identify his reincarnation for over one hundred years. In fact, what is special about The Ray of Sunlight is that it does give us a view of Gödem Truchen as a magically emanated treasure revealer before he is recontextualized as a link—albeit a very important link-in a sequence of incarnations that are proceeding through cyclic existence. 
These conclusions are interesting because current tradition frequently asserts that a treasure revealer is by definition a reincarnation of one of Guru Rinpoche's innermost disciples during the reign of King Trisong Detsen. While acknowledging that the institution of treasure revelation has never been stagnant and even now continues to transform and adapt to new challenges, there are several well known cases of serial incarnation in the early treasure traditions. ${ }^{55}$ The early biographies of Nyang-rel $\left(12^{\text {th }} \mathrm{c}.\right)$, for example, are replete with references to his status as a nirmāṇa-kāya and are also clear regarding the fact that he was the fourteenth reincarnation of King Trisong Detsen. ${ }^{56}$ Rather than this constituting evidence of the early existence of the institution of rule by incarnation, however, it demonstrates that serial incarnation is an essential component of the treasure narrative that links Nyang-rel with imperial era. That is to say, the incarnational link to King Trisong Detsen does not mean that Nyang-rel is the rightful royal heir, but signifies that he is a legitimate treasure revealer. Despite the obvious differences between the logic of magical emanation that is used to legitimize Gödem Truchen and the logic of reincarnation that is used in the case of Nyang-rel, both of the strategies are mobilized to support the institution of treasure revelation.

55 In addition to Nyang-rel, Longchenpa is also identified as an emanation of Vimalamitra. For a further discussion of his exalted nature, see: Gyatso and Germano (2000), 239-265.

${ }^{56}$ Hirshberg (2012), 44. 
There are other similarities in the early biographies of Nyang-rel and Gödem Truchen that demonstrate that the institution of rule by incarnation had not yet been initiated in these traditions and that serial incarnation when employed was intended to authenticate treasure revealers. For example, according to these biographical sources neither of these treasure revealers were expected to continue the process of reincarnation. ${ }^{57}$ Metaphorically speaking, King Trisong Detsen and the revealer Nyangrel are like the bookends that together uphold their revealed scriptures. Serial incarnation served to link concealment and revelation. Once that two-part process was complete, continued reincarnation served no more purpose. That such a highly developed individual should exit the cycle of rebirth is not surprising when one considers the origins of the concept of nirmāna-kāya. One of the consequences of recontextualizing Śākyamuni within the framework of trikāya is that sentient beings are not abandoned after the final nirvana of the Buddha because the enlightened source of his existence is the eternal and responsive dharma-kaya. Sákyamuni himself is not, however, expected to return to human form.

Based on the findings of this limited investigation, it appears that while there were indeed treasure revealers that were already identified as reincarnations of imperial-era

${ }^{57}$ Regarding Nyang-rel, see: Hirshberg (2011), 35; In Gödem Truchen's biography, it is explicitly stated that he will enter the realm of the Enjoyment Bodies after his death, and there is no discussion of his return. See: Nyima Zangpo (nyi ma bzang po) $\left(14^{\text {th }}-15^{\text {th }}\right.$ c.), 145. 
personalities, such an equation had not yet developed into a mandatory requirement for the treasure traditions. If the practice of identifying these equations had in fact already become commonplace and expected, it would have been far too easy for Nyima Zangpo to include the relevant facts regarding Gödem Truchen in unequivocal language.

\section{Part II: The Steadfast Incarnation of The Wondrous Ocean}

In contrast to The Ray of Sunlight, all of the biographies that were written in or after the seventeenth century present the Lords of the northern Treasures as an incarnation lineage: a series of concatenated incarnations that reliably return to human form as the leading patriarchs of their religious institution. In the following pages, I will argue that in such contexts trikāya theory is subtly reshaped to support the institution of rule by incarnation and that therein nirmāna-kāya is best translated as "incarnation" or "steadfast incarnation" to convey the regularity with which they return to human form for the sake of sentient beings. The text that will be analyzed is the biography of Ngakgi Wangpo (1580-1639) called The Wondrous Ocean that was written by the Fifth Dalai Lama himself in the early seventeenth century. ${ }^{58}$ Before proceeding with this

58 The Fifth Dalai Lama, Ngakwang Lozang Gyatso (ngag dbang blo bzang rgya mtsho) (1617-1682), "byang pa rig 'dzin chen po ngag gi dbang po'i rnam par thar pa ngo mtshar bkod pa rgya mtsho," In bka' ma mdo dbang gi bla ma brgyud pa'i rnam thar. TBRC W21523. : 443 - 570 (Leh: S.W. Tashigangpa, 1972). Mentioned throughout as The Wondrous Ocean. 
investigation, it is necessary to reset the stage as much has changed for the treasure tradition over the preceding two hundred years.

\section{Historical Background}

The practice center that was established by Gödem Truchen and his uncles at Mount Trazang in the late fourteenth century continues to be guided by their descendants and the descendants of Gödem Truchen's primary disciples throughout the majority of the fifteenth century. ${ }^{59}$ The figureheads of the Northern Treasure Tradition during the sixteenth and early seventeenth century, however, were treasure revealers that were recognized as reincarnations of one of three of Guru Rinpoche's twenty-five innermost disciples. Despite the fact that some of these patriarchs did enjoy relations with the community of Mount Trazang, they were largely itinerant tantric practitioners. The kingdom of Mangyül Gungtang had been conquered by Tsang in 1620, and therefore their royal family was no longer an important source of patronage for the Northern Lords.

While there is evidence that some patriarchs of the Northern Treasure Tradition engaged the kings of Tsang during the early seventeenth century, Tsang suffer defeat at the hand of Gushri Khan and the Great Fifth Dalai Lama is established as the secular

\footnotetext{
59 The development of the Northern Treasure Tradition during these centuries will be discussed at length in the third and fourth chapters.
} 
ruler of central Tibet in $1642 .^{60}$ At the end of the sixteenth century (1599), Trashi Topgyel settles at Dorjé Drak in central Tibet, and this location gradually becomes the center of the Northern Treasure Tradition and eclipses the importance of the Trazang community. As fate would have it, the Fifth Dalai Lama develops a strong relationship with several masters of the Northern Treasure Tradition (Ngakgi Wangpo, Tenzin Norbu, Chöying Rangdröl, and Pema Trinlé) and becomes a lineage holder himself. While the nature of their relationship does appear to have been grounded is spiritual experience, it is also clear that there were political aspects of the relationship. ${ }^{61}$ It is certain, however, that the Fifth Dalai Lama supported the Northern Treasure Tradition, and his aid likely fostered the transformation of Dorjé Drak into one of the six "mother monasteries" of the Order of the Ancients.

\section{Trikāya \& The Wondrous Ocean}

The Wondrous Ocean is the earliest extant biography in which the Lords of the Northern Treasures are presented as an incarnation lineage. The Fifth Dalai Lama

${ }^{60}$ The relationship between the Fifth Dalai Lama and the Northern Treasure Traditions is discussed further in Chapter Four.

${ }^{61}$ For a good example of how the Fifth Dalai Lama employed Pema Trinlé, see: Jacob Dalton (2002) "The Uses of the Dgongs Pa 'Dus Pa'i Mdo in the Development of the Rnying-Ma School of Tibetan Buddhism" (Doctoral Dissertation, University of Michigan), 172-182. 
mentions that he employs sources that were written by Trashi Topgyel and Tenzin Norbu, who were both lineage holders of the tradition, but these texts are no longer in circulation. ${ }^{62}$ Although the text is known as a biography of Ngakgi Wangpo, it includes short biographies of his better known previous incarnations as well as a complete listing of preincarnations that connects the masters to the primordial source of enlightenment. Historically, this text is significant because it overtly demonstrates that the Fifth Dali

62 There is also a version of The Hundred Tertöns (gter ston brgya rtsa) that was written by Karma Migyur Wangyel (karma mi 'gyur dbang rgyal) (f. 1650), which was written in the form of a commentary of a prayer that was authored by Trashi Topgyel. The prayer itself gives very little information about the treasure revealers as each only receives one or two stanzas. That being said, the stanza dedicated to Pema Wangyel, which is Trashi Topgyel's preincarnation, does mention his incarnational heritage (p. 257-258). But, the section that is dedicated to Lekden Dorjé (p. 266-268), including the commentary, does not mention any relationship to Gödem Truchen. It does, however, confirm that Ngakgi Wangpo is the reincarnation of Lekden Dorjé. It is also interesting that the Lekden Dorjé section mainly discusses his activities and relationship with his brother and Drigung Rinpoche. That is to say, the passage leaves one with the impression that Lekden Dorjé was not very significant as he mostly stood in his elder brother's shadow. Karma Migyur Wangpo (karma mi 'gyur dbang rgyal) (b. 17th c.), gter bton gyi lo rgyus gter bton chos 'byung. TBRC W19709. (Darjeeling: Taklung Tsetrul Pema Wangyal, 1978), 257-258, 266-268. 
Lama supports the Lords as the rightful patriarchs of the Northern Treasure Tradition and the Dorjé Drak monastic institution.

In this text, however, we find Gödem Truchen to be a single link in a chain of thirty three personalities that are steadfast in their mission to support the enterprise of Buddhism, particularly in the Land of Snows. In the following investigation our focus will be directed to the alteration of trikāya theory that is present within this key passage of the text:

The regent of Padmasambhava, that great and glorious master from Oḍ̣ịāna, was the Vidyādhara and Cakravartin of the Minyak (mi nyag) named Ngakgi Wangpo. How is it that [this name] has been established on your ears like the sound of the drums of the four directions? Among the manifold of playful emanations within the ocean of buddha-fields, he was scooped out of the great ocean with a ladle. [Thus, I am quoting from] The Garland of Stainless Lotus Blossoms, which is a verse prayer addressed to the series of thirty three lives [of this incarnation lineage], by the Third Yölmopa Treasure Revealer:

[The garland of lives begins with] (1) ${ }^{63}$ the primordial Buddha, Samantabhadra, who abides in the Unsurpassable Pure Realm. Then, appearing like a rainbow appears in the sky is the full dawn of (2) Vajrasattva. From that in

\footnotetext{
${ }^{63}$ These numbers are not in the Tibetan text. They have been added here to enumerate the incarnations.
} 
sequence came (3) Prince Dorjé Nyingpo (rdo rje snying po), (4) Khyeuchung Shela Rokpo (khye'u chung she la rog po), (5) Prince Dewa Zangkyong (de ba bzang skyong), (6) Jangsem Yeshé Nyingpo (byang sems ye shes snying po), and (7) Kedüpo Namkhé Dokchen (bka'i sdud po nam mkha'i mdog can). Then there was (8) Queen Kyegü Dakmo (skye rgu'i bdag mo), who came before the child of Zetsang (zas gtsang), which was our teacher.

Then came the mother of Prahevajra (dga' rab rdo rje) ${ }^{64}$ named (9) Khandro Dedenma (mkha' 'gro bde ldan ma). After her came (10) Khandro Rikjé Dema (mkha' 'gro rig byed bde ma). Then, there was the student of master Manjusrimitra, ${ }^{65}$ named (11) Yijin Pel (yid byin dpal). Then there was the extremely learned religious minister of King Indrabhūti named (12) Lodrö Chok (blo gros mchog). Then there was the one that did the ritual bathing named (13) Jangsem Namkhé Nyingpo (byang sems nam mkha'i snying po), who was there at the time of the miraculous birth of the great master Sindha [on an island in the playful ocean]. Around the time that the great master assumed the throne of Oḍdiyāna, there was the one that practiced in secret named (14) Sempa Chenpo (sems dpa' chen po). Then, there was the one named (15) Dewé Dorjé (bde ba'i rdo rje), who was active at the time when the great master was performing

\footnotetext{
${ }^{64}$ Garab Dorjé is the first human (semi-mythical) recipient of the Great Perfection.

${ }^{65}$ This is the principal student of Garab Dorjé, the first human recipient of the Great Perfection.
} 
activities in the charnel grounds and turning the wheel of teachings. Then, around the time when the great master was residing among the main deities of the eight varieties, there was (16) Drakpo Tumpo (drag po gtum po). Around the time when the great master was [again] practicing in the charnel grounds, there was (17) Shakya Mitra (shAkya mi tra).

Then, there was (18) Gelong Zhiwé Nyingpo (dge slong zhi ba'i snying po) who was ordained along with the great master before Ananda. Then, there was the queen of the dākiṇī, Princess (19) Mandharava (mandha ra ba). Then came (20) Binasa (bi na sa), the beer maid who causes the generation of the wisdom of great blissfulness. After this he was incarnated as (21) Chölön Yeshé Sel (chos blon ye shes gsal), the religious minister of Tsuklak Dzin (gtsug lag 'dzin), the King of Zahor. Then, he was (23) ${ }^{66}$ Dewé Jungné (bde ba'i 'byung gnas), the compiler of [the Buddha's] teachings during the time when [the great master] governed the sixteen great regions of Oḍdiyāna. At the time when the great master annihilated the heretics at Bodhgaya with his lion's roar, there was the dākiṇi that made the offerings of chests of treasure named (24) Gargyi Wangchuk (gar gyi dbang phyug). Then, there was the second coming of (25) Lhamo Denjung (lha mo bde 'byung), the mother of Dechok Dünying (bde mchog dus snying), who lived during the time when [the great master] subdued Vishnu

\footnotetext{
${ }^{66}$ Notice that the $22^{\text {nd }}$ incarnation is missing from the Fifth Dalai Lama's list. It does appear in other locations.
} 
(khyab 'jug), the King of the Naga. Then, there was the one that was devoted to the activity of honoring [the great master] at the central location of Bodhgaya, the chief named (26) Kakha Dzin (ka kha 'dzin). Then, there was the Nepali messenger named (27) Dzinamitra (dzi na mi tra), who extracted the Vajrakīla Tantra from the Asura Cave (yang le shod), [which was visited by Padmakara]. This section above is about the series of births that arrived in India.

After that, when the great master Padmasambhava came to the Tibetan Land of Snows, he was among the inner circle of five attendants that performed pure activities; he was called $(28 / 1)^{67}$ Nanam Dorjé Dujom. In the essential commentary of The Seven Line Prayer by the Precious One from Oḍdiyāna, [that was written] for the great tantric yogin he says:

Listen, tantric yogin!

Those deeds of my life experiences, They cannot be spoken as they are inconceivable!

He is the only one among the twenty five disciples of the royal court that demonstrated each of the wondrous signs of realization and was the only one that was honored [through being addressed with the above triplet]. In The River of

${ }^{67}$ The note $(28 / 1)$ means that Nanam Dorjé Dujom is the $28^{\text {th }}$ incarnation in the series, but the first Tibetan incarnation. 
Ripening Prayers, Trashi Topgyel praises him saying, "Nanam Dorjé Dujom is unobstructed like the wind!"

Then, regarding the later spreading of the teachings, the same prayer says:

A great monk will be born to the Nup (gnubs) clan.

He will obtain a completely pure attainment in [the retreat cave of Padmasambhava near Marpa's home].

Mounted on a ray of light, he is the essence of the sky.

And then later:

The Wisdom of the Buddha will take birth in the lands of the Nup (gnubs) clan.

He will achieve the deity Yamāntaka.

With this power, he will be the one to insert his dagger into solid rock. Those are the praises of the one that comes to that land.

As far as his singular blood line is concerned, he was the son of the mantra-adept named Nakpo Rozen (nag po ro zan), and his name was the translator (29/2) Tropu Lotsawa. In this lifetime, he became a great translator for the new schools of tantra. Relying upon three Indian scholars, he translated many sacred teachings. He also constructed a [great] Meitreya statue that itself [bestowed] benefits [through] seeing, hearing, remembering, and touching. 
After that, he became the lord of the most profound treasure teachings, the great wisdom holder (30/3) Gödem Truchen. ${ }^{68}$

${ }^{68}$ The Fifth Dalai Lama, Ngakwang Lozang Gyatso (ngag dbang blo bzang rgya mtsho) (1617-1682), The Wondrous Ocean, 667-671. Transliteration: dpal ODDi yAna'i slob dpon chen po pad ma 'byung gnas kyi rgyal tshab rig sngags 'chang ba'i 'khor los sgyur ba mi nyag byang pa sngags 'chang ngag dbang rig 'dzin rdo rje chos rgyal bstan pa'i rgyal mtshan dpal bzang po zhes mtshan gyi rnga gsang 668 phyogs kyi rna rgyan du 'god pa gang de'i zhing khams rgya mtshor sprul pa'i rnam rol grangs med pa'i nang nas rgya mtso chen po las skyogs kyis bcus pa ltar skye rabs kyi phreng ba sum cu rtsa gsum gyi gsol 'debs tshigs su bcad pa dri med pad dkar bzhad pa'i phreng ba zhes bya ba/_grang so gter gsum pa rig 'dzin chen po yol mo ba bstan 'dzin nor bu'am sngags 'chang chen po stobs ldan dpa' bos mdzad pa las/_'og min dag pa'i zhing du thog ma'i mgon po dpal kun tu bzang po/_mkha' las 'ja' tshon byung ba ltar 'khor gyi rnam par shar pa dpal rdo rje sems dpa'/_de nas rim pa bzhin rgyal sras rdo rje snying po/_khye'u chung she la rog po/_rgyal sras de ba bzang skyong/_byang sems ye shes snying po/_bka'i sdud po nam mkha'i mdog can/_bdag cag gi ston pa zas gtsang gi sras po'i spyan sngar skye rgu'i bdag mo/_ dga' rab rdo rje'i 689 yum mkha' 'gro bde ldan ma/_mkha' 'gro rig byed bde ma/_slob dpon 'jam dpal bshes gnyen gyi slob ma yid byin dpal/_rgyal po indra bhU ti'i chos blon blo gros mchog/_slob dpon chen po sindha rgya mtsho rol pa'i mtsho gling du rdzus te sku bltams pa'i tshe sku khrus gsol ba po byang sems nam mkha'i snying po/_slob dpon chen pos u rgyan gyi rgyal srid bzung ba'i dus 'khor sbas pa'i brtul zhugs 
'dzin pa sems dpa' chen po/_slob dpon chen po dur khrod bsil ba'i tshal du brtul zhugs kyi spyod pa mdzad cing chos 'khor bskor ba'i tshe las byed bde ba'i rdo rje/_ri bo ma la yar slob dpon chen po sde brgyad kyi gtso bor bzhugs pa'i dus kyi 'khor drag po gtum po/_slob dpon chen po dur khrod brgyad du spyod pa mdzad pa'i dus kyi 'khor shAkya mi tra/_ de rjes slob dpon chen po pad ma 'byung gnas bod gangs can gyi ljongs 'dir phebs pa'i tshe las can dag pa'i 'khor lnga'i nang tshan zhang sna nam pa rdo rje bdud 'joms zhes sngags kyi rnal 'byor pa chen por u rgyan rin po ches le'u bdun ma'i stong thun du/_nyon cig sngags kyi rnal 'byor pa:_nga yi rnam thar mdzad tshul ni:_bsam gyis mi khyab brjod mi lang:_zhes gzengs bstod cing grub rtags mi 'dra ba ngo mtshar can re ston pa'i rje 'bangs nyi shu rtsa lnga'i ya gyal gcig yin pas chos rgyal dbang po'i sdes rje 'bangs nyi shu lnga'i gsol 'debs smin byed dbang gi chu rgyun du/_rdo rje bdud 'joms rlung ltar thogs med/_ces bsngags pa de'o/_ de nas bstan pa phyi dar gyi dus gsol 'debs de nyid las/_gnubs kyi rigs 'khrungs dge slong chen po/_lho brag mkhar chur yang dag grub rnyed/_nyi zer la chibs nam mkha'i 671 snying po/_zhes dang/_gnubs yul rong 'khrungs sangs rgyas ye shes/_bsgrags kyi yang rdzong gshin rje gshed 'grub/_mthu stobs brag la phur pa 'debs der/_zhes bsngags pa brjod pa'i yul du gyur pa de dag dang gdung rus gcig pa sngags 'chang nag po ro zan gyi sras khro phu lo tsA ba byams pa dpal zhes gsang sngags gsar ma'i lo tsA ba chen po de nyid du gyur pa'i tshe paN grub rnam pa gsum la brten nas dam pa'i chos mang du bsgyur cing/_rje btsun byams pa'i sku mthong thos dran 
Despite the fact that this presentation turns out to be drastically different than the previous formulation, it does conform to the dominant Indian model of trikāya in the beginning with respect to the Dharma and Enjoyment Bodies. The wellspring of the personality is still Samantabhadra, but here the primordial Buddha is unequivocally identified as the Dharma Body. This is in contrast with The Ray of Sunlight, which implies that Samantabhadra, as the primordial Buddha, is the ground from which even the Dharma Body manifestations like Amitābha arise.

The Enjoyment Body ascends from the Dharma Body, appearing magically like a rainbow appears in the sky without diminishing the heavens, in the form of the Celestial Bodhisattva Vajrasattva. While the trikāya structure of this relationship is not remarkable, it is interesting that Amitābha and Avalokiteśvara are no longer present in the cosmology. One may only wonder if this substitution was already present in his source material or if the Fifth Dalai Lama preferred to reserve this buddha-bodhisattva team for his own incarnational heritage. If we are to consider the fact that Amitābha and Avalokiteśvara are featured in the discussion of trikāya in The Copper Palace $\left(12^{\text {th }}\right.$ c.), The Ray of Sunlight $\left(15^{\text {th }}\right.$ c.), as well as Trashi Topgyel's biography of Guru Rinpoche (early-17 ${ }^{\text {th }}$ c.) a common theme is suggested. In all three of these texts, trikāya is first being employed in service of treasure revelation, rather than the institution of rule by incarnation. Trikāya

reg don ldan 'di nyid bzhengs par mdzod do/_de rjes zab gter chos kyi bdag por gyur pa ni rig 'dzin chen po dngos grub rgyal mtshan yin la/_ 
in The Wondrous Ocean (mid-1 $17^{\text {th }}$ c.), on the other hand, is more clearly employed to legitimize a steadfast incarnation lineage.

It will also be noted that Avalokiteśvara is decidedly peaceful and is replaced by a distinctly wrathful alternative. Vajrasattva is a complicated Enjoyment Body that is often interchangeable with one or another wrathful personalities such as Vajrapāṇi. According to Snellgrove, "The highest state of all, in which all Buddha-emanations ultimately dissolve and yet continually reemerge, is the Adamantine Being (Vajrasattva) and thus it [the state] is defined as Vajra, meaning diamond or thunderbolt." ${ }^{69}$ Snellgrove is referring to tantric deity yoga here with the terms dissolve and reemerge; they refer to the stages of the meditation when one lets the visualization of oneself as an Enjoyment Body dissolve and then begins to reconstruct the visualization.

The transformative moment in the passage begins with the discussion of the series of Manifestation Bodies that proceed from the Enjoyment Body of Vajrasattva. Instead of each Manifestation Body emerging anew from the Enjoyment Body, now a single Manifestation Body enters into cyclic existence and proceeds to reincarnate therein. As discussed above, this is a significant departure from the tradition of using trikāya to describe the nature of Śākyamuni. Therein, the focus is on the fact that the source of the nirmāṇa-kāya that appeared as the Buddha persists, but there is not exactly anything remaining that could return as a reincarnation of the sage of the Sākya clan. Two

69 David L. Snellgrove (2002), Indo-Tibetan Buddhism: Indian Buddhists and Their Tibetan Successors (Boston: Shambhala), 131. 
nirmāna-kāya expressions of buddhahood are no more related than two rainbows that appear in the same sky. In a very literal sense, the Manifestation Body was originally conceived as being in the world, but not of it.

In this new formulation of trikāya, however, the Manifestation Body is able to remain metaphysically and ethically pure, but intentionally rides the drifting waves of cyclic existence from one life to the next. While he or she may be able to control the nature and location of the birth, the Manifestation Body has become intertwined, but not bound, in the process of reincarnation. The table below is intended to mirror the implied change in the nature of the Manifestation Body. It is helpful because it shows that the Manifestation Body is not a "dead end," literally or metaphorically, but is instead capable of taking rebirth within cyclic existence.

The Three-Body Theory of The Wondrous Ocean (Outline Format)

1. The Dharma Body

2. The Enjoyment Body

3. The Manifestation Body 1
a. Manifestation Body $_{2}$ (Reincarnation)
b. Manifestation Body $_{3}$ (Reincarnation)

Most of the individuals that are sited as previous incarnations of the Lords are personalities found in the extensive biographies of Padmasambhava. I have been able to find references to most of them, or at least contextual evidence, that places them in the 
key episodes of Padmasambhava's life in India and Tibet as evinced in The Life and Liberation of Padmasambhava. $^{70}$

A few examples will suffice to prove my point. Several of the incarnations are involved with the reign of King Indrabhūti in Oḍḍiyāna and Padmasambhava's life and eventual reign in that territory. An incarnation is present when Padmasambhava receives ordination from Ananda, the cousin of Sākyamuni Buddha. Several of the incarnations live at the time when Padmasambhava is practicing in the great charnel grounds of India. Several incarnations are instrumental in the early dissemination of the Great Perfection teachings that are receive by Padmasambhava and brought to Tibet. Incarnations are present when Padmasambhava has his episodes in Zahor with the king and his princess. One of the incarnations is the beer maiden Vinasā that has a relationship with Padmasambhava. And, an incarnation is present at the time when Padmasambhava defeats and converts the heretics at Bodhgaya.

\section{Distinguishing Incarnations from Emanations}

In consideration of the above, I submit that when the term tulku is used to refer to an individual that has manifested from either the Dharma or Enjoyment Bodies and continues to reincarnate within cyclic existence, it should be translated as "incarnation" or

\footnotetext{
${ }^{70}$ Ye-śes-mtsho-rgyal $\left(8^{\text {th }}\right.$ c.). The Life and Liberation of Padmasambhava. Revealer. Orgyan-glin-pa (1323-1360). Ed. Tulku Tarthang. Trans. Ken Douglas and Gwendolyn Bays (Berkeley, CA: Dharma Pub., 1978).
} 
"incarnate lama" to distinguish the phenomena from "emanations" that are more magical in nature and do not proceed continuously through the cycle of life and death. In fact, this distinction between emanations and incarnations is already in use unsystematically by translators today. When we refer to someone or something that magically appears from the Dharma Body, we tend to translate tulku as emanation. On the other hand, when we are talking about individuals of divine origins that are reborn numerous times in human form, we alternatively translate tulku as incarnation.

As demonstrated in the figure below, the process of emanation and incarnation are both involved in this model of buddhahood. The Enjoyment Body and the first Emanation Body should still be described as magically emanating from their respective sources. From there, however, the process of incarnation begins as the Emanation Body reincarnates within cyclic existence. Also notice that a change in ontological status is signified by the downward movement from the Dharma Body; the emanations are not as pure as their respective sources. The horizontal movement of the Emanation Body, on the other hand, signifies that there is not a significant change in ontological status from one incarnation to the next. 


\section{The Three-Body Theory of The Wondrous Ocean (Flowchart Format)}

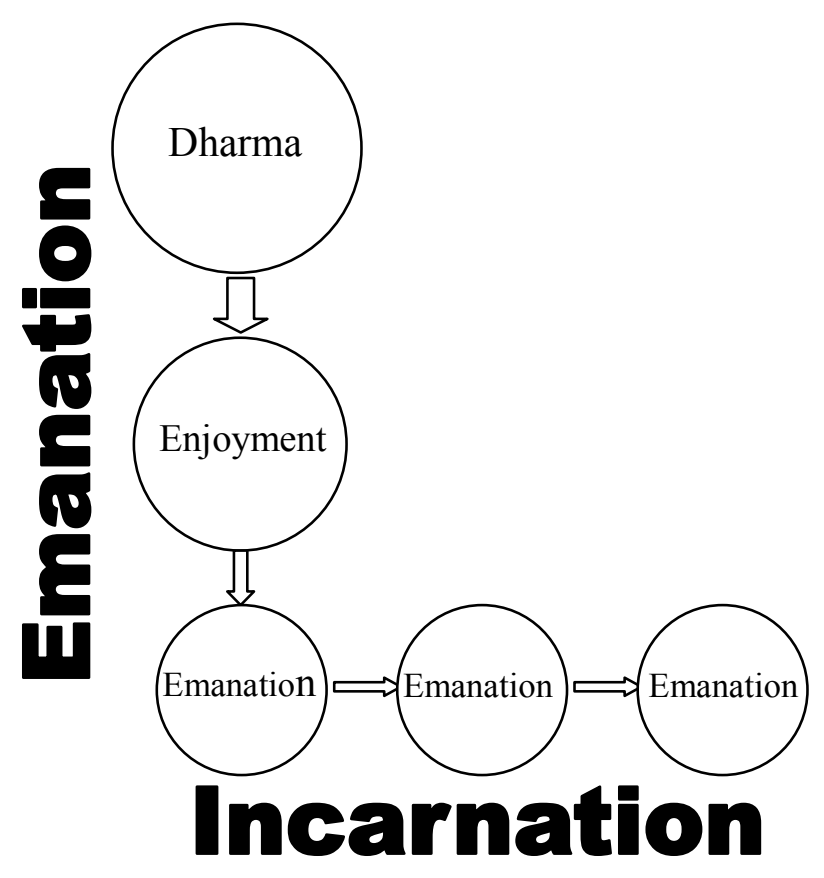

One obvious criticism of this linguistic separation of emanations and incarnations is that the latter term is used within the context of Hinduism to refer to the earthly manifestations of one of the supreme godheads. Krishna and Rama are both referred to as incarnations of Vishnu, for example, but their nature is more like what I am describing as an emanation because of their magical nature and the fact that they are not thought of as contained within cyclic existence. Nevertheless, while one could certainly find examples of Hindu personalities that returned to earth in order to maintain control of a social 
institution, this strategy for maintaining institutional integrity has not flourished in India to the same degree that it has in Tibet. ${ }^{71}$

A significant difference between the theories of buddhahood in the two sources, The Ray of Sunlight and The Wondrous Ocean, is that unlike the former, the latter supports the enterprise of tracking the past lives of an incarnation. On the one hand, the Fifth Dalai Lama traces the incarnations in a single-file line back to the primordial Samantabhadra, which supports the notion that there is a single personality moving from one incarnation to the next. There are no branches in this presentation, which can easily be cause by individuals that generate multiple nirmānạa-kāya expressions of themselves, that might confuse matters of institutional succession. On the other hand, however, the Lords have demonstrated that they are steadfastly dedicated to the Northern Treasure Tradition by returning to human form consistently.

It has been suggested that emanations reincarnate because the work that they have been sent to perform takes longer to complete than a single human lifespan. Thus, they return in order to continue whatever Buddhist enterprises they began in their previous lives. As it is not likely that the work will ever be done, we are in samsara after all, the Lords will always continue to incarnate so that they can be the stewards of the Northern Treasures. Thus, an incarnation lineage has become a very secure repository of material wealth and social authority.

\footnotetext{
${ }^{71}$ One notable modern example is the Indian guru named Sathya Sai Baba (1926-2011), who claimed to be a reincarnation of Sai Baba of Shirdi (d. 1918).
} 


\section{Chapter Conclusions: Incarnation: The Rationalized Emanation}

I have argued above that in the context of The Ray of Sunlight, which employs a version of trikāya that is inspired by the Great Perfection, the term tulku is best translated as "magical emanation" to reflect the dynamic nature of the enlightened state. I have also argued that the presentation in The Wondrous Ocean reflects a subtle but significant reformulation of the doctrine of trikāya that supports the institution of rule by incarnation. In such contexts, the term tulku can appropriately be translated as "steadfast incarnation." Instead of the earthly embodiments of buddhahood being understood as magical emanations, such as those miraculously created by the Buddha in Śāvasti, they are described as steadfast incarnations that can be relied upon to return to human form for the benefit of sentient beings. Not only does this reformulation support the enterprise of tracking incarnation lineages throughout history, it also offers a coherent explanation of the continued presence of buddhahood in the human realm and provides an implicit doctrinal foundation for the social institution of rule by incarnation.

When we compare the legitimization strategies of The Ray of Sunlight and The Wondrous Ocean side by side, we see first of all that they are similar when looking at the nature of Gödem Truchen. In both texts, he is presented synchronically as a manifestation of the transcendent Dharma Body Samantabhadra. Although this process may arguably be mitigated or perhaps facilitated by an Enjoyment Body, Avalokiteśvara or Vajrasattva, the texts do not prevaricate regarding Gödem Truchen's divine status. The Wondrous Ocean introduces a diachronic element to his legitimacy by demonstrating how the line of incarnations has been intimately involved with the development of Buddhism in India and Tibet. This legitimization strategy that supports the institution of rule by incarnation 
creates a historical sketch of the incarnation lineage that demonstrates that from its divine beginnings until the present, they have been acting to support the activities of Padmasambhava. The Incarnate Lords of the Northern Treasures are not a series of individuals that have been slowly accumulating merit over a countless series of births, as are regular sentient beings. They are not a series of incarnations that just happened to cross paths with Guru Rinpoche. It is an incarnation lineage that from its very conception has been working to further the efforts of the second Buddha, Padmasambhava. Thus, tulkus are authoritative synchronically because of their ontological relationship to the primordial source of buddhahood and diachronically because of their steadfast dedication to the proliferation of the Buddha's dharma in India and Tibet. They can, therefore, be relied upon to return to the earthly realm to continue the preservation and propagation of teachings and the institutions that act as their vessels. 


\section{Chapter 2: Preincarnations: The Narrative Appropriation of Authority}

\section{Introduction}

As discussed in the previous chapter, when the Fifth Dalai Lama authored The Wondrous Ocean, he effectively employed his own authority to confirm that the Lords of the Northern Treasures are indeed an authentic incarnation lineage. Despite the sacrosanct nature of the Dalai Lama's authority, however, there are significant hagiographic works that differ with respect to who should be included in the collective and how they should be represented. Furthermore, the earliest incarnations in this series are often not described as reincarnated lamas in their own biographies.

The contrasting historical perspectives are partially a result of the creative methodology that is embraced by the biographers. While at first it may appear that the authors are reformulating history ex nihilo, there is evidence to suggest that their creative license has certain limitations. Jacob Dalton's observations regarding texts that delineate teaching lineages are very relevant in the present context:

In most cases, they are woven together from numerous threads of teaching transmissions from the past. A lineage is simply one feasible line traced through 
this tangle of transmissions, starting at [one] point in the past and ending in the present. The line followed is usually a question of politics $[\ldots] .^{72}$

Hagiographies, as well as collections of hagiographies that trace incarnation lineages, appear to be created in a similar fashion. It is indeed likely that all of the biographical excerpts presented below are derivatives of other works. It would be surprising if all of the authors decided to highlight and suppress the same information; the differences in the biographies are to be expected.

Underlying this chapter is an assumption that hagiographers do not simply reveal facts about their subjects. I concur with the sentiments of Dalton in asserting that the details of a lineage are not just there to be discovered, but are better understood as being "retroactively constructed." ${ }^{73}$ The authoring of a biography is fundamentally a creative enterprise that is inherently concerned with notions of authority and legitimacy. While the significance of a biography cannot and should not be reduced to its function as a source of legitimization, much will be revealed about the history and the development of the Lords of the Northern Treasures through such an analysis below. A variety of

\footnotetext{
72 Jacob Dalton (2002), "The Uses of the Dgongs Pa 'Dus Pa'i Mdo in the Development of the Rnying-Ma School of Tibetan Buddhism" (Doctoral Dissertation, University of Michigan), 164.

73 Jacob Dalton (2002), 164.
} 
methodologies that biographers use to harness and redeploy the authority of the past will also be illuminated.

There are two sections of this chapter and each is dedicated to an early Tibetan incarnation of the Northern Lords. The rationale for grouping these individuals together is that they are the Tibetan preincarnations of Gödem Truchen. The first exploration concentrates on Nanam Dorjé Dujom $\left(8^{\text {th }}\right.$ c. $)$ and proceeds by way of examining a series of texts authored from the fourteenth through the twentieth century. While each of these sources is taken from a different time period, they can all be characterized as written from the Nyingmapa perspective. The analysis reveals a narrative about a young treasure tradition that is bound to the sacred geography of an ill-fated kingdom and eventually transcends this limitation. The meditations also provide the opportunity to consider the significance of Nanam Dorjé Dujom and the other figures from the court of King Trisong Detsen for the treasure traditions.

The second section is dedicated to a much more controversial figure named Tropu Lotsawa $\left(12^{\text {th }}-13^{\text {th }}\right.$ c.). Because this important personality is claimed by a variety of Tibetan Buddhist lineages, the biographical excerpts of this section were selected because of their wildly contrasting representations of Tropu Lotsawa. By examining these passages side-by-side, it becomes evident that each characterization of this important figure is correlated to a different legitimization strategy.

Throughout this chapter, I argue that biographers are able to harness the authority of the charismatic agents involved in important Buddhist foundational events through the use of hagiography. Moreover, their carefully crafted works demonstrate how the charisma of these seminal figures has been routinized through the process of reincarnation and continues to authenticate the lasting religious institutions. An obvious 
example of this alchemical manipulation of socio-religious authority can be viewed in the person of Guru Rinpoche $\left(8^{\text {th }} \mathrm{c}.\right)$. In the literature of the treasure traditions, this master is portrayed as a charismatic individual in that he possesses supernatural capabilities and is a leader even among kings. Moreover, Guru Rinpoche is represented as the most significant agent responsible for the successful establishment of a Buddhist world order in the Tibetan Land of Snows. The most prevalent legitimization strategy of the Nyingmapa treasure traditions is to demonstrate that there is an authentic and unbroken connection through which the authority of Guru Rinpoche and his empowered disciples can flow into the present.

The early incarnations of the Northern Lords that are examined in this chapter are similarly featured in narratives of foundational significance. It is, in fact, their participation in these game-changing events that distinguishs them as sources of authority. It is part of the hagiographer's craft to link his own religious community to these charismatic individuals, thereby appropriating sources of authority from the past for his own purposes. Dalton insightfully points out that, "Lineage [...] is the Buddhist mechanism for authority. The heir to a direct line of transmission, leading often back to the Buddha himself, is the legitimate holder of that lineage." ${ }^{74}$ So it is that the authoritative figures that are woven together to account for the previous lives of the Northern Lords are all charismatic personalities that were involved in events that directed the development of Buddhism in Tibet. Hagiographies of incarnation lineages are by their

\footnotetext{
${ }^{74}$ Jacob Dalton (2002), 161.
} 
very nature a series of narratives that prove that the authoritative charisma of the personalities that founded and directed the development of a particular tradition has been effectively routinized by the lineage. Incarnation lineages present a special case for the subject of the routinization of charisma because there is no need for the charismatic abilities to be passed from one person to another; the same charismatic person returns to human form to fulfill his or her social responsibilities in one life after another.

\section{Part I: Nanam Dorjé Dujom}

Nanam Dorjé Dujom $\left(8^{\text {th }}\right.$ c. $)$ is a personality that is perennially included in the narratives recounting the Early Propagation of Buddhism in Tibet. Because of his involvement in these events, Nanam Dorjé Dujom is a potent, potential source of authority for all of Tibet's many lineages of Buddhism. His importance for the Nyingmapa traditions is even more significant, however, as these traditions emphasize their link with the "older" (rnying) formulations of the dharma that were established during the Early Propagation.

The following examination of Nanam Dorjé Dujom is largely conducted through an analysis of four texts: The Ray of Sunlight, The Wondrous Ocean, The Guru Trashi, ${ }^{75}$

\footnotetext{
${ }^{75}$ Guru Trashi (gu ru bkra shis) (b. $18^{\text {th }}$ c.), gu bkra'i chos 'byung, TBRC W20916, (pe cin: krung go'i bod kyi shes rig dpe skrun khang, 1990). Mentioned throughout as The Guru Trashi.
} 
and The Nyingma. ${ }^{76}$ Each offers a unique presentation of this authoritative personality. The aim of the sections devoted to these texts is to identify the central legitimization strategies of the narratives and understand the role performed by Nanam Dorjé Dujom within each. The perspective that is generated through this analysis reveals a tension regarding Nanam Dorjé Dujom's status as an incarnation and a story about how a young treasure tradition that was originally tied to a sacred geographical location transcended these boundaries as it matured. Nanam Dorjé Dujom's role as a possible concealer of treasure will also be revisited in this chapter.

\section{The Ray of Sunlight. A Tradition Bound by Sacred Geography}

In the previous chapter, it was established that Nanam Dorjé Dujom is not unequivocally presented as the imperial-era preincarnation of Gödem Truchen in The Ray of Sunlight $\left(15^{\text {th }}\right.$ c.). Despite the fact that earlier treasure revealers grounded their authority in the process of serial incarnation to link themselves to the circumstances of concealment, this legitimization strategy is not employed in this early biography of Gödem Truchen. In the following investigation, The Ray of Sunlight is revisited with the intention of further revealing the significance of Nanam Dorjé Dujom therein. The

${ }^{76}$ Dudjom Rinpoche ('Jigs-bral ye-shes rdo-rje) (1991), The Nyingma School of Tibetan Buddhism. Trans. Rdor-rje 'Gyur-med and Matthew Kapstein (Boston: Wisdom Publications). Mentioned throughout as The Nyingma. 
following prophecy regarding the character of Gödem Truchen contains the first mention of Nanam Dorjé Dujom in the text:

As the heart-son (thugs kyi sras) of Dorjé Dujom (rdo rje bdud 'joms),

He will be adorned with the splendid attire of the wrathful ones.

He will be a religious saint or a king as prophesized.

He will show himself in that land. ${ }^{77}$

Given the fact that the later tradition maintains that Gödem Truchen is a reincarnation of Nanam Dorjé Dujom, it is surprising that the first passing mention of their relationship employs the term "heart son" (thugs kyi sras) rather than "incarnation" (sprul sku) or reincarnation "yang srid." In this context, it is clear that the term "son" is meant to convey that there is an important link between them other than blood relations. Interpreting this passage metaphorically, the latter is the former's "son" in that he possesses one of his "father's" virtues: wrathful tantric mastery. Within the alternative frame of reference in which Gödem Truchen is a magical emanation that issues forth from Nanam Dorjé Dujom, "thugs kyi sras" could be interpreted as "spiritual son" in the

${ }^{77}$ Nyima Zangpo (nyi ma bzang po) $\left(14^{\text {th }}-15^{\text {th }}\right.$ c.), 61. Transliteration: rdo rje bdud 'joms thugs kyi sras/_khro bo'i cha byad gzi brjid che/_grub thob rgyal po lung bstan can:_gnas der skye ba'i tshul bstan nas: 
sense that he was born directly from his "spiritual father's" heart. Regardless, the term does not convey the sense that the two are related through direct reincarnation.

The second scenario in which Nanam Dorjé Dujom is implicated involves the concealment of treasures at Mount Trazang. Although he is not mentioned explicitly in the following passage, one could reasonable deduce from later passages describing the contents of the treasures that he is one of the three faithful retainers:

In the passing of a moment, the master and his three faithful attendants arrived at the top of the Mount Trazang. ${ }^{78}$

The treasures that are concealed at Mount Trazang include Nanam Dorjé Dujom's ritual dagger as well as hair from his head. ${ }^{79}$ Although his presence is not explicitly stated, one could image that he is there in person to offer his hair and his ritual dagger to be placed in the time capsule. Nevertheless, if his significance had already been linked so firmly to his presence at the moment of concealment, one would expect for him to have been featured unambiguously in this scenario. The more obvious significance of Nanam

\footnotetext{
${ }^{78}$ Nyima Zangpo (nyi ma bzang po) $\left(14^{\text {th }}-15^{\text {th }}\right.$ c. $), 75$. Transliteration: se gol cig tog pa yud tsam la slob dpon dad pa can gyi 'khor gsum dang bcas pas ri bo bkra bzang zhes bya ba'i rtser byon no:

${ }^{79}$ Nyima Zangpo (nyi ma bzang po) $\left(14^{\text {th }}-15^{\text {th }}\right.$ c. $), 78$.
} 
Dorjé Dujom in this context is that the artifacts that were concealed at Mount Trazang provide a link to the wrathful ritual power of this figure.

The third appearance of Nanam Dorjé Dujom in The Ray of Sunlight, which has already been analyzed above, is within a prophecy that foretells the birth of Gödem Truchen. This passage is primarily important because of the important role of prophecy within the legitimization strategies of the treasure traditions. While the passage does convey that there is a special relationship between the two figures, it need not be translated as involving direct reincarnation.

The tantric master's last appearance in the biography is among King Mutri's entourage that gathers to bid farewell to Guru Rinpoche. The only significant importance of this passage is that Nanam Dorjé Dujom is one of the first three individuals present in the party, which supports the notion that he was also among those that accompanied Guru Rinpoche during the concealment narrative.

As will be demonstrated later in this chapter, tradition eventually clarifies the importance of Nanam Dorjé Dujom as the imperial-era preincarnation of Gödem Truchen that was actively involved in the process of concealment. The argument that Nanam Dorjé Dujom is not central to the process of concealment in The Ray of Sunlight is strengthened if one considers further the purpose of the treasures as presented therein. The second half of the biography describes how the Northern Treasures are the particular teachings that are matched to the particular needs of the Mangyül Gungtang Dynasty during the degenerate age. Through implicit analogy, the text argues that just as Guru Rinpoche was able to extend the life and reign of King Trisong Detsen by a total of thirteen years through his ritual activities, the wielders of the Northern Treasures will be able to extend the reign of the royal family of Mangyül Gungtang by offering their ritual 
services during the age of degradation. Within this context, it is not surprising that it is Prince Mutri that is featured prominently in the biography as he petitions Guru Rinpoche to conceal treasures for the sake of his ill-fated descendants in Mangyül Gungtang. ${ }^{80}$

This declaration of the importance of the Northern Treasures is not hidden at the periphery of the narrative, but is essential to The Ray of Sunlight that even features a copy of the royal edict through which the king of Mangyül Gungtang declares his faith in the patriarchs of the tradition. In this early text, the Northern Treasure Tradition is clearly represented as bound to the sacred geography of this rapidly dissolving kingdom and its ill-fated royal dynasty. When all of his appearances in the text are considered, Nanam Dorjé Dujom's significance is grounded in the promise that the Tibetan disciples of Guru Rinpoche can wield the ferocious tantric power that is necessary for ensuring the longevity of a royal dynasty.

\section{The Wondrous Ocean: Transcending Sacred Geography}

As discussed at length in the first chapter, The Wondrous Ocean $\left(17^{\text {th }}\right.$ c.) describes the continuous exploits of a steadfast series of incarnations throughout the history of Buddhism in India, Nepal and Tibet. Continuity is essential to the legitimization strategy of this biography that overtly supports the understanding of the Northern Lords as an incarnation lineage. In particular, an incarnation lineage of the seventeenth century often maintains real estate holdings and material possessions from

${ }^{80}$ Nyima Zangpo (nyi ma bzang po) $\left(14^{\text {th }}-15^{\text {th }}\right.$ c. $), 72-73$ 
one life to the next. There are also many religious responsibilities that are fulfilled by the incarnations in each of their lives that are important for the maintenance of their specific religious institution. In short, an incarnate lama is the head of a particular estate and a particular religious organization. While others may actually make all of the important decisions on behalf of the incarnate lama while he or she is a minor, the continual presence of the incarnate lama is necessary for the social institution to function. Due to their reliable nature, incarnations are very different than the messiahs of the biblical traditions; it would not be acceptable to wait indefinitely for the next incarnation. Within the Buddhist context, Meitreya could also be seen in this light as a nearly messianic incarnation for whom we wait indefinitely. An incarnate lama, quite to the contrary, can be depended upon to arrive in a timely fashion and return to fulfill his social responsibilities.

The list of previous incarnations, therefore, is a very important component of the legitimization strategy of The Wondrous Ocean. It demonstrates that the incarnations can be relied upon institutionally. The list is not a simple assemblage of unknown figures. Quite to the contrary, every single incarnation is its own source of authority. The consequence of stringing these individuals together into an incarnation lineage is that the resulting social institution inherits the authority of all of them in a manner that can be wielded in the present and the future. Each personality is like an invaluable pearl in itself, while also contributing to the grandeur of the necklace as a whole.

It is in this light that we turn our attention to Nanam Dorjé Dujom as presented in The Wondrous Ocean. First, the following passage is best understood as demonstrating that the Northern Lords took part in the Early Propagation. Although this fact is not as apparent when examining the excerpt on its own, it is obvious when its placement in the 
text is considered. The following represents the first activities of the Northern Lords in the Land of Snows.

After that, when the great master Padmasambhava came to the Tibetan Land of Snows, he was among the inner circle of five attendants that performed pure activities; he was called Nanam Dorjé Dujom. In the essential commentary of The Seven Line Prayer by the Precious One from Oḍdiyāna, [that was written] for the great tantric yogin he says:

Listen, tantric yogin!

Those deeds of my life experiences,

They cannot be spoken as they are inconceivable!

He is the only one among the twenty five disciples of the royal court that demonstrated each of the wondrous signs of realization and was the only one that was honored [through being addressed with the above triplet]. In The River of Ripening Prayers, Trashi Topgyel praises him saying, "Nanam Dorjé Dujom is unobstructed like the wind!" 81

${ }^{81}$ The Fifth Dalai Lama, Ngakwang Lozang Gyatso (ngag dbang blo bzang rgya mtsho) (1617-1682), The Wondrous Ocean, 670. Transliteration: de rjes slob dpon chen po pad ma 'byung gnas bod gangs can gyi ljongs 'dir phebs pa'i tshe las can dag pa'i 'khor lnga'i nang tshan zhang sna nam pa rdo rje bdud 'joms zhes sngags kyi rnal 'byor pa chen por u rgyan rin po ches le'u bdun ma'i stong thun du/_nyon cig sngags kyi rnal 'byor pa:_nga yi rnam thar mdzad tshul ni:_bsam gyis mi khyab brjod mi lang:_zhes gzengs bstod cing 
In this source from the seventeenth century, Nanam Dorjé Dujom is represented as the foremost of Guru Rinpoche's students. It is in his lifetime that the incarnation lineage graduates from fulfilling various minor roles, the highest of which is religious minister for various kings, and becomes a lineage of bona fide tantric masters. Whereas he is portrayed as an important disciple of Guru Rinpoche in The Ray of Sunlight, in the Wondrous Ocean he is a true master with miraculous abilities and represents the excellence of the Early Propagation.

More specifically, however, Nanam Dorjé Dujom is the archetypal personality for the patriarchs of the Northern Treasure Tradition. The human incarnations prior to Nanam Dorjé Dujom were primarily stewards of the great teachings, but not necessarily great tantric masters. As a direct disciple of Guru Rinpoche, Nanam Dorjé Dujom graduates from his role as religious minister and becomes a mature dagger-swinging tantric adept. From Nanam Dorjé Dujom on through to the present, this is the archetypal personality of the lineage and each successive incarnation appears to have been forged in his likeness.

grub rtags mi 'dra ba ngo mtshar can re ston pa'i rje 'bangs nyi shu rtsa lnga'i ya gyal gcig yin pas chos rgyal dbang po'i sdes rje 'bangs nyi shu lnga'i gsol 'debs smin byed dbang gi chu rgyun du/_rdo rje bdud 'joms rlung ltar thogs med/_ces bsngags pa de'o/_ 
It should be acknowledged that in neither The Ray of Sunlight nor The Wondrous Ocean is Nanam Dorjé Dujom explicitly involved with treasure revelation. $\mathrm{He}$ is obviously important within the narrative logic of the treasure traditions simply because of his relationship with Guru Rinpoche. But, his significance in both of these sources leans toward his status as a master of tantric ritual.

One of the consequences of recasting the Northern Lords as a series of steadfast incarnations is that the tradition transcends the boundaries of the sacred geography that were delineated in The Ray of Sunlight. By revealing that there were many previous incarnations in India and Nepal as well as incarnations that were born in various regions of Tibet, The Wondrous Ocean demonstrates that the sovereignty of the Northern Lords extends well beyond the confines of Jang and Mangyül Gungtang. The incarnation lineage is no longer portrayed as responding to only the specific needs of one particular geographical location, but is identified as being continuously present throughout the establishment of Buddhism in India and Tibet.

The consequence is that the legitimacy of the Northern Treasure Tradition is no longer tied through space and time to the kingdom of Mangyül Gungtang and its ruling dynasty. Truly, these boundaries had to be transcended as the Treasure Tradition continued to prosper long after the decline of the kingdom. The incarnations of this lineage are now free to wield the Northern Treasures for other patrons as they see fit. 


\section{The Guru Trashi: Mixed Messages}

There are many different legitimization strategies active within the pages of The

Guru Trashi (b. $18^{\text {th }}$ c.) as a result of its wide-ranging historical agendas. ${ }^{82}$ The passage below that features Nanam Dorjé Dujom appears within a section of the text that describes the events that lead to the establishment of Buddhism in Tibet during the Early Propagation. Within this larger narrative, there is a collection of biographies that describe the exploits of the 25 Tibetan disciples of Guru Rinpoche. Despite the fact that Nanam Dorjé Dujom appears toward the middle of this list, the biography does portray him as a fully realized practitioner, a dagger-swinging master par excellence:

Somewhere in the valleys of Tsang, Dorjé Dujom was born into the Nanam clan. ${ }^{83}$ When he was young, the Buddhist King Trisong Detsen appointed

${ }^{82}$ Guru Trashi (gu ru bkra shis) was a Nyingmapa historian of the eighteenth century. His history of Buddhism is referred to throughout as The Guru Trashi. This work has been invaluable because it includes not only biographies of each of the Northern Lords, but also a history of the Dorjé Drak Monastery through to the middle of the eighteenth century. Guru Trashi (gu ru bkra shis) (b. $18^{\text {th }}$ c.), The Guru Trashi (gu bkra'i chos 'byung). TBRC W20916. (pe cin: krung go'i bod kyi shes rig dpe skrun khang, 1990).

${ }^{83}$ The biography by Kongtrül Rinpoche is almost identical to the one written by Guru Trashi except for this first sentence. I included it here because it is a good introduction to the section. Jamgön Kongtrül Lodrö Tayé ('jam mgon kong sprul blo gros mtha' yas) (1813-1899), gter ston brgya rtsa'i mam thar. TBRC W20539. (Tezu, Arunachal Pradesh: 
him to the ministry of Buddhism. Through his connection with the great master [Guru Rinpoche], he later entered the path of the mantra(yana). Henceforth, be became a great mantr(yana) adept. In particular, he reached [a high level of] attainment practicing the Vajrakīla cycle. He indeed stabbed his dagger into a boulder at (has po) mountain, [and the dagger's scar] is still there until this today.

During the threefold consecration of Samyé by the abbot [Śāntarakṣita], the master [Guru Rinpoche], and the king [Trisong Detsen], Dorjé Dujom saw [that the event was taking place] through his clairvoyance and thrust his dagger into a boulder. Using his mastery over psychosomatic energies, he went directly to Samyé through the small crevice [in] the boulder without any impediments. The scar-like crevice is still discernible on that boulder today. He [also] performed many [other] amazing activities. For example, he had the supernatural power to instantaneously circumambulate the four continents, [flying] unhindered through the sky.

The meditation cave of this [master] is said to be either Drakmar Keutsang (brag dmar ke'u tshang), which is where the three [great] valleys come together, or Mount (ri mo can). In relation to this meditation cave, Shazhukpa (sha gzhugs

Tibetan Nyingmapa Monastery, 1973), 75.5. Transliteration: gtsang rong gi phyogs zhang byon sna nam gyi rigs su 'khrungs/_ 
pa ngag dbang bkra shis rnam rgyal) ${ }^{84}$ asserted that, "There is a widely known estate called Bumtang (bum thang) in the Drushül (gru shul) valley. And because of this, [I think] his homeland was indeed the Drushül (gru shul) valley." According to the biography of Dorjé Drak Pema Trinlé, ${ }^{85}$ the actual location of the valley known as Drakmar Keutsang is on the border between the great valleys of Tsang and Yardrok Pel (yar 'brog dpal). ${ }^{86}$

${ }^{84}$ Shazhukpa (TBRC: P5224) was a seventeenth century student of Ngakgi Wangpo and the author of a history that was used by both Guru Trashi and Jamgön Kongtrül Rinpoche.

${ }^{85}$ This is proof that Guru Trashi employed some version of Pema Trinlé's biography as a source of his own information.

${ }^{86}$ Guru Trashi (gu ru bkra shis) (b. $18^{\text {th }}$ c.), 171-172. Transliteration: sna nam rdo rje bdud 'joms ni/_rus sna nas ste gzhon dus/_chos rgyal khri srong gi chos blon mdzad/_phyis slob dpon chen po las sngags kyi sgor zhugs phyin chad nas sngags 'chang chen por bzhugs pa la/_rdo rje phur pa'i sgo nas grub pa brnyes pa zhig ste/_has po ri'i yang gong du brag la phur pa gt172 btab pa'i rjes da lta yang yod/_bsam yas mkhan slob chos gsum gyi rab gnas skabs su rdo rje bdud 'joms kyis ye shes kyis gzigs pa'i mgul phur brag la gzir/_rlung sems la dbang 'byor bas brag khong gseng chung ngu zhig nas zang thal gyis don te shar mar bsam yas su phebs shul brag khong gseng ni deng sang yang ngo 'phrod pa yod/_rdzu 'phrul gyis bar snang khams la thogs pa med par gling bzhi skad cig la bskor nus pa sogs ngo mtshar ba'i mdzad pa mtha' yas/_di'i sgrub gnas rong gsum 
The Nanam Dorjé Dujom characterized in the above passage is a completely realized master that is able to perform miraculous deeds at will. His expertise with the ritual dagger allows him to seemingly teleport between far off locations, and he is also able to fly. Furthermore, he is present at the event that consummated the wedding of Tibetan hearts with the Buddhism of India, the three-fold consecration of Samyé by Guru Rinpoche, King Trisong Detsen, and Śāntarakșita. Far from being a simple bystander, Nanam Dorjé Dujom employs his magical capabilities, symbolized in his ritual dagger, to transport himself through the earth itself to one of the most important locations of the Early Propagation: the temple complex at Samyé, which is the central landmark in the geomancy that was required to subdue the pre-Buddhist spirits of Tibet.

Nevertheless, the Guru Trashi is more in line with The Ray of Sunlight than it is with The Wondrous Ocean by the Fifth Dalai Lama. First of all, the Guru Trashi does not discuss any prior or later incarnations of Nanam Dorjé Dujom. He is mentioned later in the Guru Trashi while discussing Gödem Truchen, but the relationship is not one of direct

'dus pa'i brag dmar ke'u tshang ngam ri mo can du grags pa ni/_gru shul rong gi bum thang mkhar du grags pa 'di yin te/_des na 'khrungs yul yang gru shul ba shig go/_zhes sha gzugs pa ngag dbang bkra shis rnam rgyal gyis bzhed kyang/_rong gi brag dmar ke'u tshang zhes pa dngos ni gtsang rong chen dang yar 'brog dpal de'i mtshams su yod pa rdo brag pad phrin rnam thar snang ngo/_ 
incarnation. Like in The Ray of Sunlight, Nanam Dorjé Dujom is present during the concealment of the Northern Treasures. While there are only four individuals in attendance, he is not singled out as being of primary importance in the episode:

As for the profound treasures that were uncovered by this Gödem Truchen himself, when the great master [Guru Rinpoche] was on his departure path toward the land of the Rakshasa (srin po) in the southwest, the crown prince [of King Trisong Detsen] named Mutri Tsenpo (mu khri btsan po), the subject Nanam Dorjé Dujom, and the companion ḍākiṇ̄ Yeshé Tsogyel [came to meet him]. Together with his retinue of three fortunate beings, they ascended to the peak of Mount Trazang by means of the miraculous powers of the great master. Inside of trunks of stone, copper, and bronze, the three white whet stone pillars offered by the ḍakiṇī along with various manuscripts were concealed as treasures. ${ }^{87}$

${ }^{87}$ Guru Trashi (gu ru bkra shis) (b. $18^{\text {th }}$ c.), 484. Transliteration: 'di gt484 nyid kyis spyan drangs pa'i zab gter rnams ni o rgyan chen po lho nub srin po'i yul du gshegs pa'i yar lam gnod sbyin bu li'i gangs 'dabs nas rje lha sras mu khri btsan po/_'bangs sna nam rdo rje bdud 'joms pa/_grogs mkha' 'gro ye shes mtsho rgyal te las can gyi 'khor gsum dang bcas slob dpon chen po'i rdzu 'phrul gyis ri bo bkra bzang gi rtse mor phebs/_rdo/_zangs/_ khro'i ga'u kha sbyar gyi nang mkha' 'gro mas phul ba'i 'dzeng dkar gyi rdo ring gsum shog ser dang bcas gter du sbas/_ 
Furthermore, the Guru Trashi reconfirms the purpose of the Northern Treasures as intended for the Kings of Mangyül Gungtang:

When the three, the master, the profound treasure, and The King of Mangyül Gungtang come together, At that time, the Buddha's teachings in Tibet They will wield the 121 treasures. ${ }^{88}$

From this perspective, it appears that the Northern Treasures of Gödem Truchen are understood as being tied to the dominion of the dissolved kingdom of Mangyül Gungtang. Biographies of Gödem Truchen, however, appear in two sections of The Guru Trashi. The first is in the section of the text that recounts the life stories of the major treasure revealers. It is here that the presentation of Gödem Truchen aligns in many respects with his earlier biography in so much as he is represented first and foremost as a treasure revealer. Later in The Guru Trashi, there is another smaller section that discusses the abbatial succession of Dorjé Drak monastery and features Gödem Truchen. In this part of the text, Gödem Truchen is presented as the fountainhead for the incarnation lineage that holds dominion over this important Nyingmapa Monastery. The narrative

\footnotetext{
${ }^{88}$ Guru Trashi (gu ru bkra shis) (b. $18^{\text {th }}$ c.), 487. Transliteration: slob dpon dang ni zab mo'i gter:_gung thang rgyal po gsum 'dzoms na:_de dus bod kyi bstan pa ni:_brgya dang rtsa gcig gter des 'dzin/_
} 
that unfolds throughout this section of text tells the story of how a tradition that originated within the confines of the Mangyül Gungtang Empire came to be located in central Tibet. Thus, the scope of the tradition as represented by the Guru Trashi is wider than that of the Ray of Sunlight in that it lends legitimacy to the relocation of the tradition.

The only previous incarnation of Gödem Truchen listed in the Guru Trashi is unexpectedly Tropu Lotsawa. This figure, which will be discussed in detail below, is indeed present in the lineage as delineated by the Fifth Dalai Lama, but it is surprising that he is the only incarnation mentioned here. As will be shown below, many other sources leave Tropu Lotsawa out of the incarnation lineage of the Northern Treasures. Secondly, the Guru Trashi includes a direct reincarnation (yang srid) of Gödem Truchen named Jamyang Lama $\left(14^{\text {th }} \mathrm{c}\right.$.) that is not included in the Fifth Dalai Lama's presentation. At present it will suffice to say that it is very strange that this figure is not in the end counted as the second incarnation of Gödem Truchen.

\section{The Contemporary Characterization of Nanam Dorjé Dujom}

The portrayal of Nanam Dorjé Dujom in The Nyingma School of Tibetan Buddhism, which was authored by Dudjom Rinpoche in the mid-twentieth century, epitomizes the contemporary understanding of this personality. Because Dudjom Rinpoche's text has been translated into English and is readily available, the work is sure to become a foundation for understanding the history of the Nyingmapa for generations. The robust views regarding treasure revelation and serial incarnation that are expressed in this text also appear in The Hundred Tertöns, which was written by Jamgön Kongtrül Lodrö Tayé ('jam mgon kong sprul blo gros mtha' yas) (1813-1899), the champion of the 
non-sectarian movement of the nineteenth century. This work is also examined in the following investigation. As a result of exploring the development of this personality in a variety of texts above, however, it is evident that the presentation is not a timeless characterization.

In fact, the Nanam Dorjé Dujom of The Nyingma appears to be an aggregate of all the previous representations. His first appearance is among those that are sent by King Trisong Detsen to invite Guru Rinpoche to Tibet. ${ }^{89}$ This is one activity for which Nanam Dorjé Dujom is well known that is suspiciously absent from all of the biographical material presented above. These episodes were not simply created in the twentieth century, however, as they are present in a biography of Padmasambhava that was revealed in the fourteenth century. ${ }^{90}$ It is interesting that in this early text, the envoy meets with Padmasambhava in Mangyül Gungtang itself:

The king offered much gold to the preceptor and told him of the situation. Śāntarakșita replied, "The spirits of Tibet are displeased. I will go to Nepal for the time being. In order to subdue the savage spirits and demons of Tibet, there is a mantra adept named Padmasambhava, who is, at present, the most powerful in the

${ }^{89}$ Dudjom Rinpoche ('Jigs-bral ye-shes rdo-rje) (1991), 513.

90 Ye-śes-mtsho-rgyal $\left(8^{\text {th }}\right.$ c.), The Life and Liberation of Padmasambhava, Revealer. Orgyan-glini-pa (1323-1360). Ed. Tulku Tarthang. Trans. Ken Douglas and Gwendolyn Bays (Berkeley, CA: Dharma Pub., 1978), 364, 368. 
world. I will send him an invitation, and Your Majesty should do the same." So they sent messengers consecutively.

Master Padmasambhava, however, already knew that the delegation, which included Nanam Dorjé Dujom, was speeding on its way. In an instant he travelled to Mangyül Gungtang, where he met the group. He scattered their offering of gold in the direction of Ngari and said, "Everything I perceived is gold." In this way he turned Tibet into an abundant gold-producing land. ${ }^{91}$

In his capacity as one of the few individuals that delivered the invitation to Guru Rinpoche, Nanam Dorjé Dujom is in part personally responsible for the success of the Early Propagation. The episodes also demonstrate that he was a central actor in the foundational events that established a Buddhist world order in Tibet. Although these activities are not stressed in the sources that were examined earlier in this chapter, it will become evident below that his role as "inviter" was understood by some as an essential part of this archetypal personality. It may even be due to the fact that Nanam Dorjé Dujom was among the first Tibetans to have a relationship with Guru Rinpoche that he was able to reach such a high level of attainment. Thus, his second appearance in The Nyingma is as an honored and accomplished student of Guru Rinpoche that is able to perform miraculous actions. ${ }^{92}$ The text also maintains that essential transmissions of

\footnotetext{
${ }^{91}$ Dudjom Rinpoche ('Jigs-bral ye-shes rdo-rje) (1991), 513.

92 Dudjom Rinpoche ('Jigs-bra1 ye-shes rdo-rje) (1991), 535.
} 
Nyingmapa tantras, the Rongzompa lineage in particular, were given to Nanam Dorjé Dujom, which supports the notion that he was a trusted disciple of Guru Rinpoche. ${ }^{93}$

The Nyingma parts ways with The Guru Trashi by also confirming Nanam Dorjé Dujom's status as the first Tibetan incarnation in the lineage that includes Gödem Truchen, Lekden Dorjé, and Pema Trinlé. ${ }^{94}$ The text also explicitly asserts that he was among the inner circle of students that were charged with concealing scriptural treasures throughout the Tibetan landscape:

Moreover, the great pandita Vimalamitra, the generations of the religious kings, the great translator Vairocana, Nup Sangye Yeshe, Namkei Nyingpo, Nyak Jñānakumāra, Nanam Dorjé Düjom, and Nyangben Tingdzin Zangpo and others also concealed many profound treasures. They consecrated these so that later, when the time was ripe for disciples to be trained, the treasures would be practiced, and so benefit living beings. In accord with their prophecies and prayers, the king and his subjects have appeared as an ongoing, magical play of fortunate individuals and emanations, of varied social class and life-style, who have acted on behalf of the teachings and of living beings. ${ }^{95}$

\footnotetext{
93 Dudjom Rinpoche ('Jigs-bra1 ye-shes rdo-rje) (1991), 706.

${ }^{94}$ Dudjom Rinpoche ('Jigs-bral ye-shes rdo-rje) (1991), 719, 780.

${ }^{95}$ Dudjom Rinpoche ('Jigs-bral ye-shes rdo-rje) (1991), 747.
} 
This passage expresses a perspective that is also present in Kongtrül Rinpoche's The Hundred Tertöns. This passage appears at the beginning of the section that includes the biographies of the treasure revealers and is intended to describe the nature of the entire group:

Through the power of the prayers of King Trisong Detsen and his fortunate subjects, they [continue] to act for the benefit of the teachings and migratory beings by arriving in succession through the processes of birth and magical emanation in an inconceivable variety of families and exhibiting an equally inconceivable variety of lifestyles as each of the treasure revealers. ${ }^{96}$

On the surface, both of these sources appear to support the notion that a treasure revealer must be a reincarnation of one of Guru Rinpoche's disciples during the golden age of the Early Propagation. Upon closer inspection, however, both texts also seem to distinguish between those treasure revealers that are connected to these figures through serial incarnation and those that are connected through the process of magical emanation. This subtle distinction is also present in Kongtrül Rinpoche's biography of Nanam Dorjé

\footnotetext{
96 Jamgön Kongtrül Lodrö Tayé ('jam mgon kong sprul blo gros mtha' yas) (18131899/1890). gter ston brgya rtsa'i rnam thar. TBRC W20539. (Tezu, Arunachal Pradesh: Tibetan Nyingmapa Monastery, 1973), 99. Transliteration: so sos kyang smon lam thabs pa'i rje 'bangs skal ldan rnams kyi skye ba dang sprul pa'i sgyu 'phrul rigs dang spyod pa ma nges pa rim par byon nas bstan 'gro'i don mdzad pa las/_
} 
Dujom. Interestingly, the majority of the sketch of this figure is identical to the presentation in the Guru Trashi $\left(17^{\text {th }}\right.$ c.) except for this final paragraph:

His main emanations are the [chain of births] of the great Awareness Holders such as the Northern Treasure Tradition's Gödem Truchen, Jamyang Lama, and Lekden Dorjé. Besides [the chain of births of the Northern Treasure Traditions Awareness Holders], there have clearly been a few treasure revealers that have exposed concealed [treasures] up until this day, such as Belpo A-hum. ${ }^{97}$

This passage suggests that there is a distinction between those emanations of Nanam Dorjé Dujom that are connected to him through the process of serial incarnation and those that are connected to him through magical emanation. The distinction appears, at times implicitly and at others explicitly, throughout The Hundred Tertöns. For

97 Jamgön Kongtrül Lodrö Tayé ('jam mgon kong sprul blo gros mtha' yas) (18131899/1890). gter ston brgya rtsa'i rnam thar. TBRC W20539. (Tezu, Arunachal Pradesh: Tibetan Nyingmapa Monastery, 1973), 75-76. Transliteration: 75.5 gtsang rong gi phyogs zhang byon sna nam gyi rigs su 'khrungs/_[...]76.3 'di'i sgrub gnas brag dmar ke'u tshang zhes pa gtsang rong chen dang yar 'brog mtshams su rong gi brag dmar ke'u tshang zhes yongs grags su yod/_[...]76.4 rnams 'phrul gtso bo byang gter rig 'dzin rgod ldem/_'jam dbyangs bla ma/_rig 'dzin legs lden rje sogs rig 'dzin chen po rim byon dang/_gzhan yang bal po a hUM sogs da lta'i bar du sbas mngon gyi gter ston 'ga' zhig byon par gsal lo/_ 
example, when speaking about the relationship between the treasure revealer named Lhatsün Ngönmo and Prince Damzin, he employs the term "rnam 'phrul" that suggests magical emanation rather than serial incarnation. ${ }^{98}$ In a similar section regarding Nyangrel $\left(12^{\text {th }}\right.$ c.) and Guru Chöwang $\left(13^{\text {th }}\right.$ c.), Kongtrül Rinpoche refers to the latter as a speech-emanation (gsung gi rnam 'phrul) of the former. ${ }^{99}$ It is not possible for Guru Chöwang to be an actual reincarnation of Nyang-rel, because Nyang-rel achieved the fruition of the Buddhist path like Śākyamuni himself. Even though Nyang-rel is heralded as the thirteenth reincarnation of King Trisong Detsen, he is also known as the final rebirth and consummation of that sequence. This is clearly an example in which Kongtrül Rinpoche distinguishes between the two forms of exalted embodiment.

Despite the obvious significance of allowing for treasure revealers to be emanations or incarnations of important figures from King Trisong Detsen's court, the importance of the distinction should not be overstated. Regardless of the treasure

98 Jamgön Kongtrül Lodrö Tayé ('jam mgon kong sprul blo gros mtha' yas) (1813-1899) The Hundred Tertöns: A Garland of Beryl: A Brief Account of Profound Terma and the Siddha Who Have Revealed It. Trans. Yeshe Gyamtso (New York: KTD Pub., 2011), 160.

99 Jamgön Kongtrül Lodrö Tayé ('jam mgon kong sprul blo gros mtha' yas) (1813-1899) The Hundred Tertöns: A Garland of Beryl: A Brief Account of Profound Terma and the Siddha Who Have Revealed It. Trans. Yeshe Gyamtso (New York: KTD Pub., 2011), 141. 
revealer's status as an emanation or an incarnation, both can take human form-or can appear to take human form - through the processes of conception and birth. Moreover, as demonstrated in the case of Guru Chöwang, there is nothing to stop a "speech-emanation" from beginning anew the process of serial incarnation. ${ }^{100}$

\section{Section Conclusion: The Development of Treasure Authority}

In consideration of the analysis above, it is possible to establish three general manners in which Nanam Dorjé Dujom is important for the Northern Treasure Tradition. The first and arguably the earliest is that he is the archetypal personality that defines the character of the Northern Lords and the wrathful potency of their treasures. When considering the authority of the Northern Lords as an incarnation lineage, however, Nanam Dorjé Dujom is also significant as the collective's Earl Propagation representative that demonstrates the steadfast nature of the incarnations. Nevertheless, his significance is the greatest within the contemporary understanding of the treasure traditions that places him as an active participant at the time of concealment and also at the time of revelation as the revealer.

\footnotetext{
100 Nevertheless, if this distinction is not observed then one is forced to understand all "emanations" of an individual as "reincarnations." In the case of Nanam Dorjé Dujom that is presented above, that would lead one to erroneously conceive that Belpo A-hum should somehow be included as one of the Lords of the Northern Treasures.
} 


\section{Part II: Tropu Lotsawa}

The most provocative of all the incarnations of the Lords of the Northern Treasures is Tropu Lotsawa (1173-1225) (khro phu lo tsA ba). Even within the excerpts from the Nyingmapa texts translated below, his relevance is not uniformly expressed nor is his status as an incarnate lama unquestioned. As a charismatic authority figure of the Later Propagation, it is not surprising that both the Sakyapa and the Kagyupa, the two major schools that were established during this period, also seek to solidify their links to Tropu Lotsawa. The claims of the latter are the strongest as the Tropu lineage is generally understood as a sub-lineage of the Kagyupa, but this does not stop Sakyapa, Gelukpa, and Nyingmapa hagiographers from siphoning off a measure of his authority to use in their own recipes of legitimization.

In the excerpts below, which are presented in chronological order based on their dates of publication, it is evident that the charismatic authority of Tropu Lotsawa is derived from his agency in the events of the Later Propagation. This was a foundational period for these "new" traditions (gsar ma) that were founded in this nearly-mythic time when many Tibetan Buddhists reestablished their connections to India, the earthly source of Buddhism. In each of the biographies presented below, Tropu Lotsawa's authority is harnessed and transmitted to the present in a different way, and as a result the following is an effective introduction to the arts of (re)contextualization and appropriation of authority.

\section{Sakyapa - Ordination Lineage}

The following hagiography was extracted from an early collection of Sakyapa biographies. The reverential verses below were written during the thirteenth century and 
begin by praising Tropu Lotsawa's virtues as a teacher. The prose section at the end of the passage reveals that there was a reciprocal relationship between Tropu Lotsawa and the Sakyapa masters, which reflects the ecumenical tendencies of many scholars and practitioners before the rise of major sectarian rivalries. The second stanza that addresses his place in the ordination lineage of the Sakyapa, however, more directly identifies this personality's importance for the school.

[Next,] there are the teachings [attributed to] Tropu Lotsawa.

With the shining light of his insight, which is like a mandala of knowledge, He fostered the intelligence of his disciples [as a gardener fosters] a grove of lotuses.

And just like that, the deep darkness is cleared away. I prostrate to [this lamp that is like the voice of the Buddha].

For grasping externally, there is the remedy of abandonment. For grasping internally, there is the dependence on the heart-mind. All of the precepts of the [purest ordination lineage], they should be satisfied. This was transmitted to Tropu Lotsawa. 
In the aspirations and intentions [recorded by] the supreme refuge, master teacher, and eighteenth throne holder [of the Sakyapa], it is said that [Tropu Lotsawa] was very grateful for [the teachings] of the lineage of the glorious Sakyapa Family (sa skya 'khon). ${ }^{101}$

The importance of Tropu Lotsawa for the ordination lineage of the Sakyapa is in fact much greater than these verses can express. In Weberian terms, the Later Propagation can be classified as a "breakthrough" because the movement was in large part concerned with the reestablishment of monasticism in the Land of Snows. The ordination lineages that were established during the Early Propagation had dissolved. All that remained from the genesis of Tibetan Buddhism were the tantric ritual specialists

${ }^{101}$ Lodrö Gyeltsen (blo gros rgyal mtshan) (1235-1280) "kho phu lo tsA ba la bskur ba" In "'gro mgon 'phags pa blo gros rgyal mtshan gyi gsung rab" In sa skya bka' 'bum. TBRC W00EGS1017151. 15: 677-678. (Kathmandu: Sachen International, 2006).

Transliteration: khro phu lo tsA la gdams pa bzhugs/_ mkhyen pa'i dkyil 'khor legs bshad 'od zer gyis/_gdul bya'i blo gros pad tshal rgyas mdzad cing/_lta ba'i mun nag tshang tshing rnam sel ba/_sangs rgyas ske dgu'i sgron la phyag 'tshal lo/_ phyi yi dben pa spang bya'i gnyen po yin/_nang gi dben pa sems la rag las pa/_sdom bya tsa kor tshogs rnams tshim byed shog/_khro phu lo tsA ba la bskur ba'o/_/skyabs rje bco brgyad khri chen rdo rje 'chang gi dgongs bzhed thugs smon las/_dpal sa skya 'khon brgyud kyi bka' drin bsam bzhin du/_ 
who were lay practitioners that largely passed their teachings down through generations of their own descendants. The reestablishment of monasticism during the Later Propagation can be interpreted as a "moral" development because ordained monks are often thought to be more ethically pure than married, lay practitioners, even when they are performing the same public services.

The Sakyapa, which is a monastic school of Buddhism that was established during the Later Propagation, maintains two ordination lineages, both of which were received from the Kashmiri abbot named Śākyaśrỉbhadra. Tropu Lotsawa is the one that invited Śākyaśrībhadra to Tibet, and while the two travelled through the Land of Snows together, Tropu Lotsawa participated in the ordination ceremonies over which the Kashmiri presided. The authority of an ordination lineage is transmitted in a ritual ceremony from a group of monks that have already received ordination in the tradition to new monks wishing to take up their vows. While the transmission is not as esoteric as tantric initiation, much care is taken in the maintenance of the ordination lineage. Because Tropu Lotsawa had already received ordination from Śākyaśrībhadra and was familiar with the ritual procedures of the transmission, it is no wonder that he played an active role in the ordination ceremonies of traditions other than his own.

The charismatic authority of Śākyaśrỉbhadra and Tropu Lotsawa has been routinized within the ordination lineages themselves as a result of their ritual activities. It is through the ceremony of ordination that the authority of these two figures that participated in the events that helped define the Sakyapa is transmitted from the mythic past into the continuously unfolding present. When the current Sakyapa monks perform their ordination ceremonies, they are not only mimicking the activities of the Buddha and 
his monks, but they are also reenacting the narrative involving Śākyaśríbhadra and Tropu Lotsawa during the Later Propagation.

\section{Nyingmapa - Incarnation Lineage}

The primary significance of the version of Tropu Lotsawa that is found in the Fifth Dalai Lama's The Wondrous Ocean is that he is the incarnation of the Northern Lords that falls between Nanam Dorjé Dujom and Gödem Truchen. He is also the incarnation lineage's champion of the Later Propagation, which further demonstrates the steadfast nature of the Lords of the Northern Treasures regarding their responsibilities as stewards of the Buddha's dharma and dedication to the sentient beings of Tibet. Overall, the Fifth Dalai Lama's presentation is completely different than the Sakyapa excerpts above:

Then, regarding the Later Propagation of the teachings, that same prayer says:

A great monk will be born to the Nup (gnubs) clan.

He will obtain a completely pure attainment in [the retreat cave of Padmasambhava near Marpa's home].

Mounted on a ray of light, he is the essence of the sky.

And then later:

The Wisdom of the Buddha will take birth in the lands of the Nup clan.

He will achieve the deity Yamāntaka (gshin rje gshed).

With this power, he will be the one to insert his dagger into solid rock.

Those are the praises of the one that comes to that land. 
As far as his singular blood line is concerned, he was the son of the mantra-adept named Nakpo Rozen (nag po ro zan), and his name was the translator Tropu Lotsawa. In this lifetime, he became a great translator for the new schools of tantra. Relying upon three Indian scholars, he translated many sacred teachings. He also constructed a great Meitreya statue that itself [bestowed] benefits [through] seeing, hearing, remembering, and touching. ${ }^{102}$

The initial verses of the passage are interesting in that they emphasize that Tropu Lotsawa was born in the Nup clan, which is a Nyingmapa clan known for its successful preservation of the transmission of the tantric lineages that were established in the Early

102 The Fifth Dalai Lama, Ngakwang Lozang Gyatso (ngag dbang blo bzang rgya mtsho) (1617-1682), The Wondrous Ocean, 669-671. Transliteration: de nas bstan pa phyi dar gyi dus gsol 'debs de nyid las/_gnubs kyi rigs 'khrungs dge slong chen po/_lho brag mkhar chur yang dag grub rnyed/_nyi zer la chibs nam mkha'i snying po/_zhes dang/_gnubs lul rong 'khungs sangs rgyas ye shes/_bsgrags kyi yang rdzong gshin rje gshed 'grub/_mthu stobs brag la phur pa 'debs der/_zhes bsngags pa brjod pa'i yul du gyur ba de dag dang gdung rus gcig pa sngags 'chang nag po ro zan gyi sras khro phu lo tsA ba byams pa dpal zhes gsang sngags gsar ma'i lo tsA ba chen po de nyid du gyur pa'i tshe paN grub rnam pa gsum la brten nas dam pa'i chos mang du bsgyur cing/_rje btsun byams pa'i ska mthong thos dran reg don ldan 'di nyid bzheng bar mdzad do/_ 
Propagation. He is also described as a realized tantric master in his own rite, whose power is symbolized in the ritual dagger. This version of Tropu Lotsawa is cast as a Later Propagation of the Nyingmapa archetypal personality established in Nanam Dorjé Dujom. The subtle argument, therefore, is that the accomplishments of Tropu Lotsawa during the Later Propagation, a few of which are mentioned in the excerpt above, should be understood as being performed by an incarnation of a Nyingmapa incarnate lama. Therefore, there is a significant amount of the authority of the Later Propagation, which is generally understood as a narrative about the establishment of new monastic institutions, that rightful belongs to the Nyingmapa. It is through the efforts of one of the Northern Lords, after all, that many translations were completed for these developing traditions. This authority is transmitted through the Lords of the Northern Treasures to the present through the process of incarnation. Taken to the extreme, such a (re)contextualization of Tropu Lotsawa could imply that the social and religious holdings of the Tropu-Kagyupa rightfully belong to the Nyingmapa Lords of the Northern Treasures.

When one considers the characterization of Tropu Lotsawa in the Sakyapa excerpts alongside The Wondrous Ocean, a further set of analogies is suggested: Just as Nanam Dorjé Dujom participated in the mythic events of the Early Propagation by inviting Guru Rinpoche to Tibet in the eighth century, Tropu Lotsawa participated in the mythic events of the Later Propagation by inviting Sākyaśrībhadra to Tibet. Just as Nanam Dorjé Dujom was the most advanced Tibetan disciple of Guru Rinpoche, Tropu Lotsawa was the most advanced Tibetan disciple of Śākyaśrībhadra. While Guru Rinpoche is responsible for the establishment of the original and most potent tantric ritual traditions during the Early Propagation, Śākyaśrībhadra is responsible for the 
establishment of a quintessential ordination lineage of the Later Propagation. While the epithet is not as widely attributed to the latter of these individuals, Guru Rinpoche is widely known in Tibet as the Second Buddha, while Śākyaśrībhadra has been referred to as the Third Buddha. ${ }^{103}$ These analogies reflect the types of relationships that are maintained by pairs of incarnate lamas as they intentionally reincarnate in proximity to each other and maintain patterns of relational responsibility. Nevertheless, it is interesting that while the Fifth Dalai Lama mentions Tropu Lotsawa's relationship with Indian scholars in his capacity as a translator, he does not mention the subject of ordination lineages nor Śākyaśrībhadra by name. He has been completely recast as an incarnate lama, Nyingmapa in body and soul, participating in the foundation events of the Later Propagation.

\section{Nyingmapa - Rejection of an Incarnation}

As mentioned above, the Fifth Dalai Lama was extremely influential in the establishment of the Lords of the Northern Treasures. Not only did he write the authoritative biography of Ngakgi Wangpo that raised the incarnation lineage to undeniable status, he was also the primary steward of Pema Trinlé, the $33^{\text {rd }}$ incarnation in

\footnotetext{
${ }^{103}$ An example can be found in the following text: Kunga Drönchok (kun dga' grol mchog) (1507-1565), "shAkya mchog ldan gyi rnam thar zhib mo rnam par 'byed pa," In gsung 'bum/shAkya mchog ldan. TBRC W23200. 16: 11 - 244.( new delhi: nagwang topgyel, 1995), 283.
} 
the lineage and the reincarnation of the Fifth Dalai Lama's teacher Ngakgi Wangpo. The Fifth Dalai Lama also performed all three levels of ordination for Pema Trinlé and directed his education by arranging his tutors, which were the foremost scholars and saints of the seventeenth century. Throughout Pema Trinlé's massive autobiography, called The Clear White Mirror $\left(17^{\text {th }}\right.$ c.), he reveals the Fifth Dalai Lama as his personal guru and receives and follows his instructions well into his majority. It is thus very surprising that Pema Trinlé does not follow the Fifth Dalai Lama's lead when it comes to Tropu Lotsawa.

Tropu Lotsawa receives very little mention in the massive autobiography, which is frequently preoccupied with the lives of the previous incarnations. While reporting on the exploits of his twenties, Pema Trinlé mentions that he performed a few benedictions using the White Mañjuśrī Prayer of the Tropu lineage. He also mentions in passing that he saw a painting that depicted Tropu Lotsawa's father, who was a Nyingmapa master in his own right. It is not until the year 1690, however, when Pema Trinlé is fifty years of age, that he discusses Tropu Lotsawa as a possible previous incarnation. The following passage is a small excerpt from a larger section of the autobiography that is written as a travel log. At this point in his life, Pema Trinlé retires from his position as the patriarch of the Dorjé Drak Monastery and embarks upon a year-long pilgrimage to Jang Ngamring to visit the holy sites where he lived in an earlier life as Gödem Truchen. While a few more of the details of this journey will be discussed elsewhere in this dissertation, the relevant episode within the present context occurs when Pema Trinlé is on the return trip to central Tibet and visits the monastic seat of the Tropu-Kagyupa lineage: 
Then, I crossed over River Shap (shab chu) and had the midday meal in the grasslands in the lower part of the valley of Tropu. Not long after that, I arrived at [the monastic seat called] Tropu. Because this place was the seat of the translator Tropu Lotsawa, they were foolishly attached to the thought that the translator Tropu Lotsawa Jampa Pel (khro lo byams pa dpal) resided within the incarnation lineage of Lekden Dorjé. And, thus they wished for such things as to obtain a reading transmission of the biography of Trashi Topgyel that was written by the Drukpa [Kagyupa] named Drukpa Sangdorwa ('brug pa sang rdor ba).

[They] were setting up a commemoration service for [the great man of their lineage] named Tropuwa Namjé Pema Karpo (khro phu ba rnams rje pad ma dkar po). I rested a little in the Zhelré (zhal ras) temple and then went on pilgrimage [to the local sites] right away. I prayed and made the scarf offering to the resplendent field of merit, that amazing statue of Meitreya. Because [great things] were said about the statue, there was a great audience there. ${ }^{104}$

\footnotetext{
${ }^{104}$ Padma Trinlé (padma 'phrin las) (1641-1717), pad+ma 'phrin las kyi rang nyid kyi rtogs brjod rab dkar shel gyi me long. TBRC W23811 (Unpublished), 610-611.

Mentioned throughout as The Clear White Mirror. Transliteration: shab chu la rab brgal te khro phu'i mda' ne thang zhig tu gdugs t611 tshod byas/_de nas mi ring bar khro phu dga' ldan byams pa'i gling du 'byor/_gnas 'di khro phu lo tsa ba'i gdan pa yin pas khro lo byams pa dpal rig 'dzin rje'i skye brgyud du bzhugs pa'i rmongs zhen dang/_chos rgyal dbang po'i sde'i rnam thar 'brug pa sang rdor bas mdzad pa'i lung rgyun zhig kyang rnyed
} 
In the above passage, Pema Trinlé directly contradicts the notion that Tropu Lotsawa was in the same incarnation lineage as himself. This is extremely surprising given the close relationship between Pema Trinlé and the Fifth Dalai Lama. The fact that the people of the Tropu monastery knew of the connection to the Lords of the Northern Treasures suggests that the link was forged in generations prior to the Fifth Dalai Lama. Furthermore, the reference to the biography of Trashi Topgyel suggests that this might be the source of the connection between Tropu Lotsawa and the Northern Lords and could be the Fifth Dalai Lama's resource as well. Regardless, in the eyes of Pema Trinlé, his authority does not depend in any significant way upon the person of Tropu Lotsawa.

\section{Nyingmapa - Incarnate Lama \& Treasure Revealer}

In the eighteenth century Guru Trashi, Tropu Lotsawa is surprisingly the only individual identified as a previous incarnation of Gödem Truchen, which is interesting because this is the one incarnation that Pema Trinlé rebuffed. In the following passage

du re ba sogs yin/_khro phu ba rnams rje pad ma dkar po'i sku mchod kyi chog mangs tshugs pa dang 'grig/_zhal ras lha khang du cung zhig ngal gsos te de ma thag mchod mjal byas/_byams chen gyi sku ngo mtshar zhing byin rlabs kyi gzi 'od 'bar ba la snyan shal dang phyag mchod phul zhing smon lam btab/_ma+nya+ji dang ka To ra zangs dung brda tu sogs che tshad las brgal ba'i khyad 'phags yin zer ba mang po'i mjal kha byung/_ 
from the Guru Trashi-the final two sentences were added by Kongtrül in his nineteenth century The Hundred Tertöns - Tropu Lotsawa's status as an incarnate lama is not buttressed by identifying any of his previous incarnation. This biography is unique, however, because Tropu Lotsawa has been (re)contextualized as a treasure revealer.

As for the treasures of Tropu Lotsawa, they are the tantras related to the deity called Dungmarchen (mdung dmar can), and so we have [the hagiography of] Tropu Lotsawa. He was born as a son to a powerful tantric practitioner named Nganchang Rozen Nakpo (sngags 'chang ro zan nag po) of the Order of the Ancients. [His] religious system is a single [stream] known as [containing elements] of both the Pakdru-Kagyupa (phag gru bka' brgyud) and Zungzhi Troling (zung bzhi'i khro gling). He had the inconceivable qualities of both learning and accomplishment.

He [also] invited three [important figures to Tibet], they were Penchen Shakya Shri (paN chen shAkya shri), Buddha Pel (buddha dpal), and Mitra Dzoki Tepen Drup (mi tra dzo ki ste paN grub). He constructed a great Meitreya statue for liberation through seeing that was twenty eight measures tall.

As a learned and accomplished master of Tibet, this great person has left his mark through his teachings. This master of Sanskrit extracted and translated treasures, such as the seven-part Earth-Demon (gnod sbyin dbyug tho can gyi rgyud le'u bdun pa gnyags dznya na ku $\mathrm{mA}$ ras) [which was taken] from a 
vulture's hollow. The longevity prayer in the last chapter of that was edited by the great Penchen Bimala (paN chen bi ma la). ${ }^{105}$

This biography is clearly attempting to recast Tropu Lotsawa as an archetypal Nyingmapa hero-saint. In addition to stressing that he was the son of a powerful tantric ritual specialist, it also describes him as an important treasure revealer. As a master of Sanskrit, he was able to unearth Indian texts and translate them into Tibetan. According to the biography of Śākyaśrībhadra, it does appear that one of their preoccupations while

${ }^{105}$ Guru Trashi (gu ru bkra shis) (b. $18^{\text {th }}$ c.), 503. Transliteration: mdung dmar can 'di'i rgyud ni khro lo'i gter ma yin te/_khro phu lo tsa ba gnubs byams pa dpal ni/_sngags rnying ma'i sngags 'chang ro zan nag po zhes pa'i nus ldan zhig gi sras su 'khrungs/_chos lugs phag gru bka' brgyud/_zung bzhi'i khro gling gnyis su grags pa'i ya gyal yin/_mkhas pa dang grub pa'i yon tan bsam gyis mi khyab/_paN chen shAkya shri/_buddha dpal/_mi tra dzo ki ste paN grub gsum spyan drangs/_rgyab 'dom nyer brgyad yod pa'i byams sku mthong grol chen mo bzhengs/_ bod kyi mkhas grub gcig la bstan pa la phyag rjes 'di rang che/_lo chen 'dis bya rgod gshongs nas gnod sbyin dbyug tho can gyi rgyud le'u bdun pa gnyags dznya na ku mA ras bsgyur pa dang/_de'i le'u mtha' ma'i tshe sgrub gsal byed paN chen bi ma las mdzad pa sogs gter nas gdan 'dren par mdzad pa yin no/_kong 'og gi rnam sras kyi skor 'di dag sa lugs rnam sras bod du tshang bar bzhugs pa'i rgyun bdag gis kyang nos pa yin no/_ 
travelling together in Tibet was hunting down archived Sanskrit texts. ${ }^{106}$ The Guru Trashi suggests that these activities qualify him as a treasure revealer. Indeed, there are several treasure texts in the tantric cannon that are attributed to the revealer Tropu Lotsawa. According to Kongtrül, these teachings continued to be propagated in Sakyapa circles in the nineteenth century, and this is how he was able to receive their transmission.

From the current perspective, it is evident that the characterizations of Nanam Dorjé Dujom and Tropu Lotsawa enjoy parallel developmental trajectories. The trend is that over time these authority figures are more explicitly associated with the enterprise of treasure revelation and are also absorbed by incarnation lineages. ${ }^{107}$ In the end, these two socio-religious institutions come to define the personalities in this text, but it is clear that either Nanam Dorjé Dujom or Tropu Lotsawa were identified as incarnate lamas in their own times. Nor is it likely that their involvement with treasures truly defined their identity. Nevertheless, in the short biography above, the authority of Tropu Lotsawa is harnessed and brought from the past to the present through the process of incarnation to support a largely Nyingmapa legitimization strategy. Furthermore, it is also suggested that his translating accomplishments may also be understood as a part of the enterprise of

${ }^{106}$ David P. Jackson, ed. 1990. Two Biographies of Śākyaśrībhadra: the eulogy by khrophu lo-tsa-ba and its "commentary" by bsod-nams-dpal-bzang-po (Hamburg: The Institute for the Culture and History of India and Tibet at the University of Hamburg), 14. 107 Davidson talks about the reframing of renaissance figures as treasure revealers. Davidson (2005), 227. 
treasure revelation, which deemphasizes his connection with the New Schools that began during the Later Propagation.

\section{Kagyupa - Uncle-Nephew Lineage \& Sacred Geography}

This final biographical representation of Tropu Lotsawa's life is perhaps the most straight-forward of the five presented in this chapter. It is found within a recently published (2009) compendium of biographies of important Kagyupa patriarchs, but it is likely based upon much older but unmentioned sources. The irony of presenting this biography last is that it is likely the most natural view of the importance of this figure before he was (re)contextualized to suit the needs of other traditions. As would be expected, there is no mention of Tropu Lotsawa herein as an incarnate lama or a treasure revealer.

Tropu Lotsawa's biography constitutes the majority of an entry in the compendium that describes the genesis of the Tropu-Kagyupa lineage and the establishment of the Tropu monastery as a sacred geographical location within the Kagyupa worldview. As such, the biography begins with an account of the lives of Tropu Lotsawa's uncles, Gyeltsa Rinpoché (rgyal tsha rin po che) and Kunden Repa (kun ldan ras pa). Gyeltsa Rinpoché is the elder of the brothers, and he is the one who purchases the land that is to become the epicenter for the Tropu lineage. The younger brother, Kunden Repa, establishes the earliest temple on the property. In the section of the biography that has been omitted below, it is evident that the spiritual power of these two brothers has already transformed the Tropu property into sacred geography for the Kagyupa lineage before the birth of their nephew. 
Within the current context, however, the biography presented below is important because it employs another important version of lineage to connect the charismatic authority of Tropu Lotsawa to the present. The uncle-nephew system of maintaining institutional integrity is essentially a version of the father-son form of succession that has been adopted for the celibate lifestyle of monks.

The brothers, Gyeltsa Rinpoché (rgyal tsha rin po che) and Kunden Repa (kun ldan ras pa), were the uncles and the nephew was Tropu Lotsawa Jampa Pelam Tsültrim Sherap (khro phu lo tsA ba byams pa dpal lam tshul khrims shes rab). [Tropu Lotsawa] was born in 1173, the year of the Water-Monkey, to the father, Jopen (jo 'phan) of the Nub (gnubs) clan, and the mother, Sekmo Seljé (bsreg mo gsal byed).

Tropu Lotsawa learned to read and write from Gyeltsa [Rinpoche] and Kunden Repa through the uncle-nephew connection. He took his novice vows at age eight. At the age of eleven, he received such texts as Dharmakīrti's book of logic at the feet of a pure and reliable friend. From this untainted individual, he received many texts, such as Meitreya's Middle Way. He was victorious in debates through his use of logic.

When he was seventeen years of age, from the teacher named Tsetön Kunzang (rtse ston kun bzang), he received the quintessential instructions [that enabled him to complete the performance of] the five types of mandala offerings hundreds of times for [cycles] such as the Dorying (rdor dbying). He performed extensive enlightened activities such as those for producing wealth for those who were poor through his practices related to Namsé (rnam sras), the god of wealth. 
Having learned the art of translation from his virtuous uncles, he became an expert. At the age of nineteen, having taken full ordination in the middle of the entire monastic assembly of the faithful, which included the abbot Gyeltsa Rinpoche and others, he was adorned with the name Jampa Pel. Through his uncle-nephew link with Gyeltsa, he received everything, such as the 136 different teachings (gdams ngag) and the thirteen special transmissions (bka' babs). When he was twenty four and Gyeltsa was reaching the end of his life, he brought the transmission of teachings to completion.

Later, he travelled to Nepal. While there he became a disciple of Penchen Buddha Shri (paN chen buddha shrI) and Mitra Joki (mi tra jo ki) and ended up inviting them to Tibet. [Everyone] received many teachings and in the Tibetan realm there was much thankfulness. Having done inconceivable beneficial deeds for [Tropu Lotsawa's] disciples in the region of Tsang, they departed for Five Peak Mountain in China.

When he was thirty two years of age, he went before the Lord of the Drigung Kagyupa in central Tibet and received the complete transmission and initiation into the [tantric] tradition of the Kagyu.

When he was thirty three years of age (1207 CE), he met the sixty five year old Khaché Penchen (kha che paN chen) on the road to Dromo (gro mo) and invited him [to stay with his monastic community]. [Through this master, he became a holder] of a very pure ordination lineage [that is traced back to ancient India] and which remains unbroken until this day. He [established] the great temple of Tropu and he constructed an eighty cubit high Meitreya statue. 
The brother of Khaché Penchen, named Sangyé Dawa (sangs rgyas zla ba), heard that there was an arhat that was actually living in Sri Lanka (sing ga la), and thus he went there and he met [the arhat]. Having stayed there for three months, he participated in the celebration at the end of the summer retreat. There was a stupa there where relics of the Buddha resided and if you were to place the five types of flowers in the basket [there], they become consecrated and never age and perished. [Sangyé Dawa] was given them for the purpose of offering them to Penchen Shakya Shri (paN chen shAkya shrI), [the great Drigung Kagyupa and] reincarnation of Nāgārjuna named Kyopa Jikten Gönpo (skyobs pa 'jig rten mgon po), and the Great Meitreya statue [being constructed by] Tropu Lotsawa. And, the flowers were offered to the head of the Great Meitreya statue.

In accordance with the prophecies of his lama, when he arrived in places like the great mountains of Kham (khams), many disciples would assemble. And thus, he disseminated far and wide the purest quintessential teachings and texts of the precious teacher in $\ddot{U}$ (dbus), Tsang (gtsang), Nyel (gnyal), Yor (yor), and the three regions of Ngari (mnga' ris).

In the year of the Earth-Rabbit, when he had reached the age of forty eight, he [performed his practices] at a Tropu family estate called Khardrak Sengé Dzong (mkhar gyi brag seng ge rdzong). He brought countless students, [including famous students and students from major clans], to maturation through his teachings (gdams ngag) of initiation. Because he gathered together the quintessential teachings of three [non-Tibetan teachers] and the Kagyupa tradition, [he was able to give] hundreds of such teachings. He even made many translations [of those works]. In the year 1225, he passed beyond earthly sorrows. 
Then there came many people who were learned and accomplished such as the throne holder [of the lineage], the great bodhisattva Sönam Sengé (bsod nams seng ge), his student Yang Tsewa Rinchen Sengé (yang rtse ba rin chen seng ge), and his student, the precious saint Butön Rinpoché (bu ston rin po che) (1290-1364). Later, there would be a request for the omniscient Butön to come to Zhelu (zhal lu). There he was made the eleventh in the abbatial succession of Zhelu. Through the three gateways of teaching, debating and writing, he lived a full life there. He gave the highest praise to Gyelten Rinpoché (rgyal bstan rin po che). Through his great and extensive enlightened activities, the lineage came to be known as "Zhelu."

Other than that, Gyeltsa had [another] uncle-nephew student named Chegom (lce sgom). And that person's student was Michik Rema (mi cig re ma). In brief, that student together with their pupils came to be pervasive in this [particular] lineage of teachings. And it is in this group, that there is what we call the Tropu-Kagyu. ${ }^{108}$

\footnotetext{
${ }^{108}$ Sönam Gyatso (bsod nams rgya mtsho) (2009), "khro phu lo tsA ba'i rnam thar/ 21," In bka' brgyud chos 'byung nor bu'i phreng ba. TBRC W1KG4232. 1: 87 - 90. [s.1.]: [s.n.], [n.d.]. http://tbrc.org/link?RID=O2CN370|O2CN3702CN3932CN14662CN1553\$W1KG4232.
} Transliteration: rgyal tsha rin chen mgon dang dbon kun ldan ras chung dang khro phu lo tsA rnams kyi rnam thar/_kyang de lta bu zhig bya snyam pa'i dam bca' mdzad/_chos gra 
der 'gro mgon phag gru las gdam ngag rnams rdzogs par gsan nas bsgom pas spangs rtogs la mnga' brnyes shing grub thob chen po gyur/_bla ma'i gdan sa phag grur gtsug lag khang brtsegs pa sogs bsod nams kyi zhing dam pa brtan par mdzad/_nam zhig mu ge byung ba'i tshe khro phu'i mchod khang gi sgo la phyag mkhar gtug gtug mdzad nas/_rnal 'byor ma rnams/_de ring rnal 'byor pas bsod snyoms shig zhu'o gsungs pas/_mchod khang gi sgo 'phar nas 'bru zhag lnga'i bar du ma zad pa'i grub rtags bstan nas yul gyi mu ge zhi ba byas pa sogs 'dul bya rnams gang la gang 'dul gyi smin grol gyi sa la bkod nas mthar dgung grangs bdun cu pa me glang lor (1217) la shar phyogs bya phug tu sku gshegs/_rgyal tsha rin po che dang/_kun ldan ras pa sku mched kyi dbon po/_khro phu lo tsA ba byams pa dpal lam tshul khrims shes rab ni/_yab gnubs jo 'phan dang/_yum bsreg mo gsal byed gnyis kyi sras su chu sprel lor sku 'khrungs (1173) rgyal tsha dang kun ldan ras pa khu dbon las 'bri klog dang/_dgung lo brgyad par dge tshul bsgrubs/_bcu gcig par dge bshes gtsang ba'i mdun nas tshad ma rnam nges sogs gsan/_gtsang dkar pa las dbu ma byams chos sogs mdo sngags kyi gzhung mang po gsan/_rgol ba mang po rigs pas tshar bcad/_bcu bdun par rtse ston kun bzang las/_rdor dbyings sogs dkyil 'khor lnga brgya lhag gi phyag len man ngag bcas gsan sgrub rdzogs par gnang/_rnam sras kyi rjes 'dzin gyis longs spyod kyi mi phongs pa sogs phrin las rgyas/_zhang dge ba las lo tsA bslabs nas mkhas par gyur/_bcu dgu par mkhan po rgyal tsha rin po che sogs dad pa'i dge 'dun grangs tshang dbus su bsnyen par rdzogs nas mtshan byams pa dpal du gsol/_rgyal tsha khu dbon las gdams ngag mi 'dra ba brgya dang sum cu rtsa drug dang/_bka' babs 
bcu gsum sogs mtha' dag gsan/_nyer bzhi par rgyal tsha sku gshegs khar gdams ngag rnams rdzogs par gnang/_de nas bal yul du byon/_paN chen buddha shrI dang/_mi tra jo ki bsten nas bod du gdan drangs/_gdams ngag mang du gsan zhing bod yul la dka' drin che ba byung/_gtsang phyogs su gdul bya'i don bsam gyi mi khyab pa mdzad nas ri bo rtse lngar bzhud/_dgung lo so gnyis la dbus su rje 'bri gung pa'i spyan sngar bka' brgyud pa'i lugs kyi dbang khrid gdams pa thams cad rdzogs pa gsan/_dgung lo gsum cu rtsa gsum la kha che paN chen dgung lo drug cu re lnga pa (1207) la gro mo'i lam la byon nas spyan drangs/_gzhi thams cad yod par smra ba'i mkhan brgyud las sdom rgyun rnam par dag pa dri ma med pa da lta'i bar du ma chad par byung/_khro phu dga' ldan gtsug lag khang chen po btab/_byams chen khru brgyad bcu pa bzhengs/_paN chen gyi mched zla sangs rgyas zla bas/_sing ga la gling du dgra bcom pa dngos su bzhugs pa gsan nas der byon nas mjal/_zla ba gsum bzhugs nas dgag dbye thob nas/_sangs rgyas kyi ring bsrel bzhugs pa'i mchod rten zhig dang me tog lnga za ma tog tu bcug nas rnying pa dang stor ba mi 'byung ba byin gyis rlabs nas/_paN chen shAkya shrI dang/_klu sgrub kyi sprul pa skyobs pa 'jig rten mgon po/_khro phu lo tsA ba byams pa dpal gyi byams chen rnams la 'bul ched bskur ba/_me tog byams chen gyi dbu la phul/_bla ma'i lung bstan ltar khams ri bo cher sogs su byon nas gdul bya mang du 'dus/_de bzhin/_dbus gtsang/_gnyal/_yor/_mnga' ris skor gsum la bstan pa rin po che'i gzhung man ngag dri ma med pa rnams dar zhing rgyas par mdzad/_dgung lo zhe brgyad sa mo yos bu'i lor khro phu gnyen mkhar gyi brag seng ge rdzong du sgrub pa mdzad/_bla chen bsod nams 
The transmission of authority as represented in this passage is phrased in terms of the uncle-nephew link. It was the bond between uncles and nephew that nurtured Tropu Lotsawa and allowed him to become the learned man with the potential to perform great deeds. And, it was through the link to other nephews that the Tropu Lotsawa lineage itself was maintained after the early generations of the tradition. The strategy of passing authority through one's nephew is not limited to the Kagyupa persuasion, but is rather a more widespread byproduct of the celibate institution of monasticism. Perhaps the most

dbang phyug/_mkhan chen byang chub dpal/_gnyos lo/_rong pa rga lo sogs slob grangs las 'das pa la dbang khrid kyi gdams ngag gis smin par mdzad/_paN grub gsum dang bka' brgyud kyi man ngag du bsdud nas man ngag brgya rtsa sogs mdzad/_'gyur yang du ma mdzad nas lo (1225) de nyid la mya ngan las 'das so/_gdan 'dzin byang sems chen po bsod nams seng ge/_de'i slob ma yang rtse ba rin chen seng ge/_de'i slob ma bu ston rin po che rin chen grub sogs mkhas grub kyi skyes bu du ma byon/_phyis su kun mkhyen bu ston zhal lur gdan 'dren zhus nas/_zhal lu'i mkhan rabs bcu gcig pa gnang nas/_sku tshe hril por 'chad rtsod rtsom gsum gyi sgo nas rgyal bstan rin po che la srid zhu bla med mdzad/_phrin las shin tu rgyas pas zhal lu'i lugs zhes grags pa byung ngo/_gzhan yang/_rgyal tsha khu dbon gyi slob ma lce sgom dang/_de'i slob ma ma cig re me yin te mdor na/_slob ma/_yang slob dang bcas pa'i chos brgyud dar khyab byung ba 'di la khro phu bka' brgyud ces grags so/_ 
natural form of succession is though one's own male heirs. The idea, which is not absent in Tibet, is that at least some measure of the charisma of the parent is passed to the children through the blood or bones. As celibate monks, the abbot of a monastery should not have any natural heirs of his own, so the next best thing would be the son of his brother.

This Kagyupa biography is also unique in that it emphasizes Tropu Lotsawa's involvement with non-tantric Mahayana learning. This link is apparent in his mastery over the logic of Dharmakīrti and his prowess in debate. Furthermore, the preoccupation with Meitreya and the works attributed to him by Asanga demonstrates how dedicated he was to this form of Buddhism. The culmination of this devotion is fully apparent in his creation of the incredibly large Meitreya statue that put his monastery on the map for pilgrims for hundreds of years to come. This biography goes to great efforts to support the claim that the statue was indirectly blessed by Śākyamuni Buddha himself as flowers blessed by his relics in Sri Lanka were carried to Tibet and offered to the head of the statue. This Meitreya statue that was in effect consecrated with the blessings of the Buddha further transforms Tropu into a sacred geographical location, a center-point of orientation for religious pilgrims for generations.

In sum, the primary legitimization strategy that is employed in the biography above is the claim that authority best flows from uncles to nephews. This is how the tradition was formed, and it was how it was transmitted to later generations. After taking time to demonstrate how the teacher-student relationship among individuals that are not related can be traced through to Butön and the Zhalu lineage, the author returns to the uncle-nephew lineage that forms that Tropu Kagyupa tradition itself. All of the authority generated through the wonder and amazement of his foundational activities, like his 
invitation of the Indian scholars, his hand in the revitalization of monastic ordination, the building of the Meitreya statue, his translation of many works for Tibetan, is brought from the past to the present through an unbroken sequence of uncles and nephews.

\section{Chapter Conclusion: The Art of (Re)contextualization \& Appropriation}

Tropu Lotsawa is a profoundly interesting incarnation of the Lords of the Northern Treasures in that he has been claimed by so many traditions. Each author uses the art of hagiography to repackage him in a manner that suits the needs of his own tradition. The similarities in the presentations suggest that the authors consulted preexisting source material as part of their own creative processes. The differences are shaped by the authors' choices regarding which "facts" to prioritize and which to ignore. All of the biographies, excluding Pema Trinlé's, can be interpreted as attempting to harness the charismatic authority of Tropu Lotsawa as an agent of the Later Propagation and explain how that authority has been routinized and transported from the past to the present. Dalton eloquently epitomizes the subject of authority asserting that, "Lineagethe tracks of a teaching, a text, or a person backward in time to its point of origin - is the Buddhist mechanism for authority." ${ }^{109}$ In the passages above, however, we have been presented with a series of examples of how lineage can be variously conceived. Metaphorically, a lineage is a conduit for connecting a source of authority to a social institution favored by the author that requires the buttressing of historical precedence.

\footnotetext{
${ }^{109}$ Jacob Dalton (2002), 161.
} 
Each of the sources demonstrates a different manner of transcending the gulf of time. The Sakyapa source emphasizes the ordination lineage, and thus charismatic authority is conceived of as passing from one individual to the next through the ritual initiation that is fundamental to monasticism. The Nyingmapa sources variously prioritize Tropu Lotsawa's role as an incarnate lama and as a treasure revealer. In theory, there is no need for the routinization of charisma for incarnate lamas as it is the same charismatic person that returns to the earthly plane of existence time and time again. In practice, as will be discussed later in this dissertation, there are procedures for the identification, enthronement, and training of incarnate lamas that can be understood as essential components in the transfer of authority from one incarnation to the next. Finally, the Kagyupa source places emphasis on the social institution of passing authority from uncles to nephews and also stresses that the valley of Tropu itself is a sacred geographical location capable of passing its charismatic blessings to those who grace its confines.

Of the two incarnations examined above, Nanam Dorjé Dujom is obviously more significant for the Lords of the Northern Treasures. Even if his status as an incarnate lama did not develop until the sixteenth or seventeenth century, his status as a wrathful tantric master is essential to the personality of the Northern Lords. Equally clear is the fact that Nanam Dorjé Dujom's importance expands exponentially as he is eventually recast as an active participant in concealment that returns as a series of treasure revealers. 


\section{Chapter 3: Stages in the Development of an Incarnation Lineage \& A Treasure Tradition}

\section{Introduction}

The charismatic individual who founds a new social order is the root source of authority for that institution, because that individual's endowment of charisma- both as a supernatural gift and as a personality trait that aids one's ability to lead - is what made the creation of the new community possible and gave it its distinctive character. The founder's charisma must then be routinized into the institutional workings of the religious community if there is to be any sense of continuity after his or her passing. Thus, at its core, an investigation of the routinization of charisma begins with examining the methods and rationale used to determine the succession of leadership during the early history of a new religious tradition. Institutionalization is by its very nature an innovative process that stabilizes a tradition while attempting to preserve its defining charismatic foundations. In the Tibetan Buddhist context, the incarnation lineage clearly develops into a reusable paradigm for retaining the creative inspiration of a religious tradition.

In the Fifth Dalai Lama's The Wondrous Ocean $\left(17^{\text {th }}\right.$ c. $)$, we find the first clear evidence that the charisma of both Nanam Dorjé Dujom $\left(8^{\text {th }}\right.$ c. $)$ and Gödem Truchen $\left(14^{\text {th }}\right.$ c.) that is at the heart of the Northern Treasure Tradition has been preserved in the incarnation lineage of the Northern Lords. It has been established above, however, that this traditional understanding of the Northern Treasure Tradition is not clearly present in The Ray of Sunlight, the earliest biographical source for the tradition. The aim of this chapter is to examine the circumstances involving the passage of the authority of the 
Northern Treasure Tradition from Gödem Truchen through to the first of the Northern Lords to be recognized as a young child, Ngakgi Wangpo (1580-1639).

The following investigation has been divided in four parts. The first involves the transmission of authority through the fifteenth century in the hands of the clansmen of Gödem Truchen and his immediate disciples. The second part describes the transmission of the Northern Treasure Tradition from Śākya Zangpo $\left(15^{\text {th }}-16^{\text {th }}\right.$ c. $)$ to Lekden Dorjé (1512-1625), who is recognized as the reincarnation of Gödem Truchen in the midsixteenth century. The third narrates the passage of authority from Lekden Dorjé to Trashi Topgyel, who is a reincarnation of Lekden Dorjé's brother, in the late sixteenth century. Finally, the fourth section describes the identification and training of Ngakgi Wangpo at the end of the sixteenth century and early seventeenth century. As is demonstrated through the following investigation, the Northern Treasure Tradition gradually adopted the institution of rule by incarnation through a series of innovations, each representing the further routinization of the charisma of the Northern Lords.

This chapter also offers insight into the relationship between the institution of rule by incarnation and the hereditary Nyingmapa traditions of the sixteenth century. Throughout this chapter, we witness the slow transformation of the Northern Treasure Tradition, which was a family-based tradition following the succession customs of the Order of the Ancients that formed during Tibet's period of fragmentation, into a Nyingmapa monastic institution at Dorjé Drak that was headed by a series of incarnated patriarchs. As part of this organizational transformation of the Northern Treasure Tradition, one series of patriarchs is elevated in status to be the supreme source of leadership for the tradition. The significance of the elevated ontological status of these patriarchs changes and picks up a variety of meanings throughout this time period. It is 
through this organizational change that the tradition fully embraces the social institution of rule by incarnation.

\section{Historical Context}

While the kingdom of Mangyül Gungtang persisted throughout the fifteenth and sixteenth centuries, the most salient political developments were taking place closer to Central Tibet. Politics were dominated in the early-fifteenth century by the Pakmodrupa, a line of Kagyupa patriarchs who ruled from Nedong, which is about sixty miles southeast of Lhasa. ${ }^{110}$ The Pakmodrupa decline throughout the course of the century as the Rinpungpa clan and the princes of Tsang gradually accumulate power. While the Kagyupa Order enjoyed the greatest political success during this time period, the newly established Gelukpa Order proliferated throughout the century as well.

During the sixteenth century, the Tsangpa, the Pakmodrupa, and the Rinpungpa patriarchs were all active participants in the political sphere. Meanwhile, Sönam Gyatso (1543-1588), the Third Dalai Lama of the Gelukpa Order, established relations with the Tümed chieftain named Altan Khan and also received the patronage of the Pakmodrupa, who awarded them the Ganden Podrang estate near Drepung Monastery. These events set

110 The historical facts in this section have largely been drawn from Kapstein (2006), 116-135. 
the stage for the faceoff between the Tsangpa-Kagyupa and the Gelukpa influences in the seventeenth century.

\section{Sources}

During the second half of the seventeenth century, Pema Trinlé (1641-1717) authors an extensive compilation of the Gongpa Düpé Dowang (dgongs pa 'dus pa'i mdo dbang) scriptures, which is a kama tradition that has been maintained by the Order of the Ancients since the Early Propagation, upon the request of the Fifth Dalai Lama (16171682). ${ }^{111}$ At this time, he also authored a collection of biographies of the Gongpa Düpé Dowang lineage holders that features biographies of several important figures of the Northern Treasures, including Lekden Dorjé and Trashi Topgyel. Many of the passages that are employed in this chapter have been drawn from this late-seventeenth century source as there does not appear to be any significantly earlier biographies of Lekden Dorjé, who tradition maintains passed away in $1625 .^{112}$ This chapter also relies upon the Guru Trashi, which was introduced in Chapter Two. This text is very helpful as it includes an entire section that describes the faithful passage of the authority of Gödem Truchen through time and space to the Lords of the Northern Treasures at Dorjé Drak Monastery.

${ }^{111}$ For example of how Pema Trinlé performs such feats, see: Dalton (2002), 172-182.

${ }^{112}$ Later in this chapter, I suggest that a better estimate for the date of his death is 1580 . 


\section{Transmission of Scriptural and Institutional Authority: From Gödem Truchen to Śàkya Zangpo (15 $5^{\text {th }}$ c.}

During the lifetime of Gödem Truchen, he and his uncles established a practice center at Mount Trazang that was the epicenter of the Northern Treasure Tradition. After his passing (c. 1409), the scriptural transmission and the institutional leadership of the young tradition was maintained by Gödem Truchen's clansmen and closest disciples. This form of succession, which developed among the Nyingmapa traditions that survived through Tibet's period of fragmentation, continued to be observed at Mount Trazang through at least the middle of the sixteenth century. The final patriarch of this 150 year period was the treasure revealer named Śakya Zangpo $\left(15^{\text {th }}-16^{\text {th }}\right.$ c. $)$, who was recognized as a reincarnation of Gö Pema Gungtsen $\left(8^{\text {th }}\right.$ c.), a minister of King Trisong Detsen. One of the reasons that Śākya Zangpo is so important for this tradition is that he passes the Northern Treasures to Lekden Dorjé, the reincarnation of Gödem Truchen. This section, however, will focus on the lineage holders and patriarchs that maintained the tradition between Gödem Truchen and Śākya Zangpo.

Since the ultimate goal of this dissertation is to analyze the development of the Northern Lords as an incarnation lineage, the patriarchs between Gödem Truchen and Lekden Dorjé that were not incarnate lamas might at first seem irrelevant. One might presume that the authority of one incarnation is automatically passed to the next through the process of rebirth. As Chögyam Trungpa Rinpoche points out, however, the training 
of an incarnate lama is very important. ${ }^{113}$ There must be an authentic transmission of the defining teachings of a tradition from one incarnation to the next. Thus, the incarnate lama is an authoritative figure ontologically-speaking as a reincarnation of a charismatic figure from the past, but is also a source of authority as a recipient and holder of the quintessential teachings of the tradition. From this perspective, the importance of the patriarchs between Gödem Truchen and Lekden Dorjé is quite clear. They are responsible for a major component of the treasure tradition's authenticity and authority. They are the vessels that preserved the nectar of the ḍākiṇi and kept it warm for future generations.

The transmission of the Northern Treasure Tradition is commonly understood to have been passed down from Gödem Truchen through three separate lineages: one that descends through his disciples, one that descends through his son, and another that descends through his mother. ${ }^{114}$ Eventually, these strains of the lineage are reunited in the person of Pema Trinlé who receives all three transmissions and synthesizes them into one lineage. The present concern, however, is to establish a continuity of scriptural transmission from Gödem Truchen to Śākya Zangpo. These figures were likely connected through a web of intertwined relationships; one particular delineation, however, can be

113 Chögyam Trungpa (2009), The Mishap Lineage: Transforming Confusion into Wisdom (Boston: Shambhala).

${ }^{114}$ Martin J. Boord (1993), Cult of the Deity Vajrakila: According to the Texts of the Northern Treasures of Tibet (Byam-gter Phur-ba) (Tring: Institute of Buddhist Studies), 30. 
extracted from the record of the teachings received by the Fifth Dalai Lama. Much more than a simple list of teachings, this text also delineates the lineage of previous holders for each set of transmitted teachings that he received. The information in the following table was extracted from the Fifth Dalai Lama's record of the reading transmission of one particular set of ritual arrangements of the Northern Treasure Tradition.

\section{An Example of a Transmission Lineage Connecting Gödem Truchen to Śākya Zangpo ${ }^{115}$}

1. Gödem Truchen (1337-1409)

2. Namgyel Gönpo (rnam rgyal mgon po) (The Son of Gödem Truchen) (b. $14^{\text {th }}$ c.)

3. Jampa Shényen (byams pa bshes gnyen) (b. $14^{\text {th }}$ c.)

4. Sangyé Pelzang (sangs rgyas dpal bzang) (b. $15^{\text {th }}$ c.)

5. Namkha Gyeltsen (nam mkha' rgyal mtshan) (b. $15^{\text {th }}$ c.)

6. Śākya Zangpo (First Yölmopa Lama, Teacher of Lekden Dorjé) (b. 15 $5^{\text {th }}$ c.)

Of the three lineages that were transmitted by Gödem Truchen, it is the one passed on to his son that is important here. From this blood relation of Gödem Truchen, the transmission is then passed along three times from master to initiate before reaching Sákya Zangpo. Notice that it is important to identify all of the holders of the lineage; one may not skip through the incarnate lamas to shorten the list of transmissions.

115 The Fifth Dalai Lama, Ngakwang Lozang Gyatso (ngag dbang blo bzang rgya mtsho) (1617-1682), The Current, 263-264. 
It should be observed, however, that the patriarchs of the above list are connected through the process of textual transmission. The information for the following table, on the other hand, has been drawn from the section of The Guru Trashi, which is precisely occupied with the task of delineating the heritage of the Dorjé Drak abbacy.

The Lineage of Patriarchs Connecting Gödem Truchen and Sākya Zangpo According to The Guru Trashi ${ }^{116}$

1. Gödem Truchen ${ }^{117}$ (1337-1409)

2. Nganchang Chenpo Dorjé Pelba (sngags 'chang chen po rdo rje dpal ba) (b. $14^{\text {th }}$ c.)

3. Rinchen Drak (rin chen grags) (b. $14^{\text {th }}$ c.)

4. Dorjé Gönpo (rdo rje mgon po) (b. $14^{\text {th }}$ c.)

5. Jampa Shényen (b. $14^{\text {th }}$ c.)

6. Tsenden Ngakwang Drakpa (mtshan ldan ngag dbang grags pa)

7. Sangyé Pelzang (b. $15^{\text {th }}$ c.)

116 The Guru Trashi is a very helpful source as the author has arranged the biographical information regarding the early patriarchs of the Northern Treasure Tradition in order to narrate the origins of the Dorjé Drak abbacy. Guru Trashi (gu ru bkra shis) (b. $18^{\text {th }}$ c.). $g u$ bkra'i chos 'byung. TBRC W20916. (pe cin: krung go'i bod kyi shes rig dpe skrun khang, 1990), 668-674.

${ }^{117}$ The names listed in bold in this list are those that also appear in the list generated from The Current. 
8. Nganchang Chögyel Sönam (sngags 'chang chos rgyal bsod rnams) (b. $15^{\text {th }}$ c.)

\section{Namkha Gyeltsen (b. $15^{\text {th }}$ c.)}

\section{Sākya Zangpo (First Yölmopa Lama, Teacher of Lekden Dorjé) (b. $15^{\text {th }}$ c.)}

The Guru Trashi portrays the monastic tradition that is eventually established at Dorjé Drak as beginning with Gödem Truchen and identifies a continuous series of patriarchs of the community that was founded by this charismatic treasure revealer. Most of the individuals in these lists are either descendants of Gödem Truchen or descendants of Dorjé Gonpo, who is one of his primary disciples. For example, Dorjé Pelba received scriptural transmission directly from his uncle, Gödem Truchen, and was also the second patriarch of the tradition. Rinchen Drak and Dorjé Gönpo were brothers, and the latter was one of the innermost disciples of Gödem Truchen. The sixth patriarch, Ngakwang Drakpa, was the son of Rinchen Drak. ${ }^{118}$ This pattern of succession continues until Śākya Zangpo who receives both scriptural and institutional authority from Namkha Gyeltsen, who was the son of the fifth patriarch, Jampa Shényen. It is clear, therefore, that succession was determined in the early Northern Treasure Tradition following the customs of the Order of the Ancients. Among these early patriarchs, Namkha Gyeltsen

\footnotetext{
${ }^{118}$ For more information regarding the family connections between these early figures, see: Jurgen Wilhelm Herweg (1994), The Hagiography of Rig 'dzin Rgod kyi ldem 'phru can and Three Historical Questions Emerging from It (M.A. thesis, University of Washington), 40.
} 
stands out as a recognized treasure revealer, and Dorjé Pelba is identified as the son of parents that were both treasure revealers. ${ }^{119}$ Namgyel Gönpo is described as an emanation of the Buddhas of the three times, while Namkha Gyeltsen is said to embody all three aspects of trikāya. ${ }^{120}$ Serial incarnation, however, does not appear to be a factor is determining succession.

Through the investigation of these early patriarchs of the Northern Treasure Tradition, two important facts have emerged. The first is that one's status as an incarnate

119 The relevant information for Namkha Gyeltsen was drawn from: "thugs sras nam mkha' rgyal mtshan gyi rnam thar mthong ba don lden ma rig mun sel." (circa late- $\left.15^{\text {th }} \mathrm{c}.\right)$ In byang gter lugs kyi rnam thar dang mang 'ongs lung bstan. TBRC W27866. 1 vols. (Gangtok, Sikkim: Sherab Gyaltsen and Lama Dawa, 1983), 208, 233. The relevant information for Dorjé Pelba was drawn from: "bla ma rnams kyi rnam thar 'od kyi 'phreng ba" (circa late-15 $5^{\text {th }}$ c.), In byang gter lugs kyi rnam thar dang mang 'ongs lung bstan. TBRC W27866. 1 vols. (Gangtok, Sikkim: Sherab Gyaltsen and Lama Dawa, 1983), 181-182. Note: While the authorship of this text is unclear, it appears to have been written by Sangyé Pelzang (b. 15th c.), whose biography is the last to appear in the collection.

${ }^{120}$ For further information regarding the life of Namgyel Gönpo, Gödem Truchen's son, see: "bla ma rnams kyi rnam thar 'od kyi 'phreng ba" (circa late-15 ${ }^{\text {th }}$ c.), In byang gter lugs kyi mam thar dang mang 'ongs lung bstan. TBRC W27866. 1 vols. (Gangtok, Sikkim: Sherab Gyaltsen and Lama Dawa, 1983), 173. 
lama does not exempt one from requiring scriptural transmission. An incarnate lama must even receive transmission for the texts that were revealed by his previous incarnation. This subject of training is very important within the context of rule by incarnation and will receive additional attention below. The second fact is that in the case of the Northern Treasure Tradition, institutional leadership was also transmitted through a series of nonincarnational patriarchs before being placed in the hands of Lekden Dorjé. These facts reveal a muti-dimensional depth to the authority that is invested in an incarnate lama of a robust incarnation lineage.

\section{Recognition of Adults, Karmic Relationships \& Memory: From Sākya Zangpo to the Ngari Brother: Pema Wangyel \& Lekden Dorjé (Mid-16 ${ }^{\text {th }}$ c.)}

This section analyzes the passage of the Northern Treasure Tradition from Śākya Zangpo $\left(15^{\text {th }}-16^{\text {th }}\right)$ to the Ngari Brothers and the eventual identification of the younger of these brothers, Lekden Dorjé (1512-1625), as the reincarnation of Gödem Truchen. While the system of rule by incarnation has not been fully embraced by the Northern Treasure Tradition at this time, there are several elements of this institution that are present. Lekden Dorjé's identification occurs later in his life when he is already a fully matured master, and this status is consummated through his own visionary power. This investigation also offers an opportunity to question the nature of the Northern Treasure Tradition and its leadership during the sixteenth century.

\section{Consenting Adults: Initial Contact with the Northern Treasure Tradition}

The excerpts presented below have been selected to demonstrate the gradual manner in which Lekden Dorjé and Pema Wangyel are introduced to the Northern 
Treasure Tradition. It should be noted, however, that throughout their formative years, the Ngari brothers receive a wealth of teachings from their father. Well into his majority, Lekden Dorjé continues to receive instructions from his father and his brother, which demonstrates the family nature of their clan-based tradition. That being said, the brothers also become devout students of Śākya Zangpo.

Then, Pema Wangyel arrived at the capital. There he met with the master of mantras, Śākya Zangpo. When he later returned [home], he went before his younger brother and said: "Something important has happened. I met with a man from Drangso (drang so) named Śākya Zangpo. [We need] to wield the dharma like this [man]. I saw him brandish the power of the Mahākaruṇā (thugs rje chen po) and the Awareness-Holder (rig 'dzin gdung sgrub) cycles [of the Northern Treasure Tradition]. His body, speech, and heart-mind [all bore the marks of great experience]. I must go to meet him!" [...] They sent a written request asking for a reading transmission and received word that they should come. After eleven days had passed, he arrived together with his brother and they were granted an audience. Just by seeing his body, [Lekden Dorjé] experienced bliss-emptiness. They received the Mahākarunāa and the Awareness-Holder cycles [of the Northern Treasure Tradition], the root empowerment for the Assemblage of Sugatas (bde 'dus rtsa dbang) cycle, the longevity practice from the Radiant Longevity Benediction (tshe sgrub 'od zer dra pa), the Hayagrīva (rta mgrin nyang lugs lcags ral can) cycle of the Nyang (nyang) Treasure Tradition, Sākya Zangpo's own autobiography, prophecies, and treasure practices revealed at the Red Stupa [at Samyé] as well as other teachings. Lekden Dorjé wanted to go as a ritual 
attendant for Śākya Zangpo to help with the renovations at the stupa in Nepal, but he wasn't able, so he returned home. ${ }^{121}[\ldots]$

[Soon after that, Lekden Dorjé] entered into a silent familiarization retreat for the Mahākaruṇā (thugs rje chen po 'gro ba kun grol) cycle. He engaged in

${ }^{121}$ Pema Trinlé (padma 'phrin las) (1641-1717), "rig 'dzin mnga' ris pa chen po legs ldan bdud 'joms rdo rje'i rnam thar," In bka' ma mdo dbang gi bla ma brgyud pa'i mam thar. TBRC W21523. : 351 - 392 (335-376). (Leh: S.W. Tashigangpa, 1972), 347-348. Mentioned throughout as the The Biography of Rindzen Lekden Dorjé. Transliteration: de nas 348 paN chen rin po che rgyal sar byon te/_sngags 'chang shAkya bzang po dang mjal te phyir byon nas gcung legs ldan zhabs la/_da res byin pa la don byung/_khrungs yul drang so ba mtshan shAkya bzang po zer ba dang mjal/_chos 'di 'dra bsnams 'dug gsungs/_thugs rje chen po dang rig 'dzin gdung sgrub skor bsnams 'dug pa gzigs pas/_sku la 'dar chung dang/_gsung la brjod med/_thugs la rtog med kyi bde nyams dpag sgyed 'khrungs te bdag mjal bar phyin e chog zhus pas/_khyod rang shog bu thul nas dpe bris/_bris tshar ba dang dbang lung zhu ba dang sgrags te 'gro gsungs/_de nas zhag gcu gcig song ba dang sku mched lhan du byon nas mjal/_sku gzigs pa tsam gyis bde stong gi nyams su song/_thugs rje chen po/_rig 'dzin gdung sgrub/_bde 'dus rtsa dbang/tshe sgrub 'od zer dra pa/_rta mgrin nyang lugs lcags ral can/_kho rang gi rnam thar lung bstan mchod rten dmar po'i gter ma/_gsol 'debs le'u bdun sogs gsan/_rje drang so ba bal yum du mchod rten bya rung kha shor gyi shig gsos la byon pa'i zhabs phyir 'byon bzhed kyang ma nus par phyir byon/_ 
virtuous practice for the entirety of the fifteenth night. At dawn, a humongous image of the kind and magnificent incarnation of the lama Śākya Zangpo sat in the sky before him composed of the five colored lights. And, he gave him instructions. As the vision was about to disappear, it changed into the Mahākarunā. The vision passed, and he sang a song about what just happened. Having completed even the fire ritual [for mending any shortcomings of the practice], he came out of the retreat and went before Pema Wangyel, to receive teachings. $^{122}[\ldots]$

The younger brother, Lekden Dorjé, and his master went to Nepal. Although the elder brother, [Pema Wangyel], initially stayed behind in Kyidrong (skyid grong), he changes his mind and also came to Nepal. The siblings then engaged in many pilgrimage activities together.

122 Pema Trinlé (padma 'phrin las) (1641-1717), The Biography of Rindzen Lekden Dorjé, 350. Transliteration: thugs rje chen po 'gro ba kun grol gyi bsnyen pa ngag mtshams la bzhugs/_tshes bco lnga'i nub mo mtshan thog thag gi dge sbyor mdzad pas/_tho rengs drin can drang so sprul sku chen po'i sku mtho tshad tsam 'od zer 'phro ba zhig mdun gyi nam mkhar 'od lnga'i klong na bzhugs te zhal gdams 'ga' gsungs te yal khar thugs rje chen po'i rnam bar lam gyur te song ba byung mgur bzhes shing/_kha skong sbyin sreg kyang grub nas mtshams grol te paN chen drung du byon nas chos gsan/_ 
It was there that he met with the prophecies about the coming of the true rebirth of Gödem Truchen to Nepal. In the cave [that was graced by Padmasambhava] called Yang Leshö (yang le shod) he was blessed with innumerable pleasant visions. He saw the [good] fortune of the treasures of Gödem Truchen. He saw himself asking for blessings and praying. He saw himself travelling [to various locations in India] and saw the region signs of those places. $^{123}[\ldots]$

On the way back to Kyidrong, [Lekden Dorjé] acted as Śākya Zangpo's assistant at Riwo Pembar (ri bo dpal 'bar). Both the master and the disciple stayed in retreat there for one year. His familiarity with the Yidams increased and many

123 Pema Trinlé (padma 'phrin las) (1641-1717), The Biography of Rindzen Lekden Dorjé, 356. Transliteration: gcung legs ldan rje dpon slob gnyis kyis bal por byon/_gcen paN chen dpon slob skyid grong du bzhugs kyang phyis thugs 'gyur te bal por byon/_sku mched lhan du gnas rten rnams zhib mjal mdzad/_rigs 'dzin rgod ldem can gyi skye ba dngos bal por yong ba lung bstan pa de dang mjal/_yang le shod du rgod ldem rje'i gter skal 'dug pa gzigs te byin rlabs zhus shing smon lam mdzad/_a su ra dang rgya'i gong kha dkar chung tshun du phebs te yul ltas gnas gzigs byin rlabs dag snang spro dga' dpag med byung/_gar phebs kyi sar paN chen rin po cher chos zhu mang du byung ba thams cad legs par gsan/_ 
pure visions manifested. After [Lekden Dorjé] was released from the year-retreat and had departed for Lobo (glo bo), [Śākya Zangpo] departed. ${ }^{124}$

The connection that is forged between Śākya Zangpo and the Ngari brothers is clearly transformative from the very beginning. The brothers are particularly drawn to Sákya Zangpo as the charismatic patriarch of the Northern Treasures. They thus immediately seek an audience with Śākya Zangpo and begin to receive a host of transmissions from their new teacher. The younger of the brothers, Lekden Dorjé, is in his early twenties when he begins to receive the Northern Treasures. In sharp contrast to all of his subsequent incarnations that are identified and introduced to the Northern Treasures as children, Lekden Dorjé is well into adulthood before he even encounters the scriptures that eventually define his personality. As discussed below, his consummation as an incarnate lama does not occur until after he becomes a master of the Northern Treasures.

Despite the strength of their first encounters with one another, it is interesting that the nature of the karmic relationship between the Śākya Zangpo, Pema Wangyel, and

124 Pema Trinlé (padma 'phrin las) (1641-1717), The Biography of Rindzen Lekden Dorjé, 356-357. Transliteration: skyid grong brgyud/_ri bo dpal 'bar du rje shAkya 357 bzang po'i zhabs phyir byon te dpon slob gnyis kas lo mtshams la bzhugs/_thugs dam 'phel zhing dag snang mang po shar/_lo mtshams grol bstun glo bor phebs pas yul zhing du phebs 'dug par brten/_ 
Lekden Dorjé is not immediately identified. In fact, Lekden Dorjé must first be initiated into several cycles of the Northern Treasure teachings and achieve a degree of mastery over these cycles before he receives his first visionary experiences that reveal that his destiny is intimately intertwined that of Śākya Zangpo and the Northern Treasure. But, these early visionary experiences do not identify Lekden Dorjé as a reincarnation of Gödem Truchen.

\section{A Master of the Northern Treasures}

In the following passage, Lekden Dorjé follows his new master to the religious center at Mount Trazang in Jang Ngamring. While there, he steeps himself more thoroughly in the heritage of the Northern Treasures. Through a complete study of the literature of the Northern Treasure Tradition that was housed at Mount Trazang and through a series of extensive retreats that stretched out over ten years, Lekden Dorjé becomes a legitimate master of the treasure tradition.

Then, that winter, they went to Dedröl (bde grol) in Jang Ngamring before his master's heart-son, and Śākya Zangpo received the Zangtel (zang thal) [teachings of the Great Perfection]. Having arrived as his master's attendant, Lekden Dorjé also received the cycle of teachings. While he was there, he received teachings by day and wrote manuscripts by night. Every morning and evening he practiced the liturgical rites (bskang gso). He stayed there for six months performing these and other activities.

Then, while receiving the elaborate vase-empowerment, he made the following promise: "I, from this day forward for three years will stay and serve 
you as your attendant." During that time, he received the reading transmission for every last verse of the treasure teachings of the system associated with those of Mount Trazang. He requested the nurturing loving kindness of the ritual details (phyag len), the direct instructions (dmar khrid), and the essential teachings (gnad gsang). Then, he cultivated [all that he had learned during this period] for ten years at Riwo Pembar (ri bo dpal 'bar). ${ }^{125}$ During this [retreat], the signs of progress, such as the four visions, came to completion, and he prayed for the protection of the compassionate one. He offered everything that he possessed except for his worn out cushion to his lama. ${ }^{126}$

${ }^{125}$ A retreat center associated with Milarepa.

126 Pema Trinlé (padma 'phrin las) (1641-1717), The Biography of Rindzen Lekden Dorjé, 358-359. Transliteration: de nas dgun byang ngam ring bde grol du thugs sras rin po cher rje drang so ba zang thal gsan pa'i phyag phyir byon nas zang thal skor gsan/_der nyin mo bka' chos gsan/_nub mo phyag dpe bris/_snga dgongs bskang gso mdzad pa sogs zla ba drag gi bar du mdzad/_359 de nas zang thal gyi spros bcas bum dbang skabs dam bca' 'di ltar mdzad de/_bdag deng nas lo gsum gyi bar zhabs phyir 'brangs te sdod/_de bar du ri bo bkra bzang pa'i lugs kyi gter chos shlo ka gcig kyang ma lus pa'i dbang lung/_phyag len dmar khrid gnad gsang brtse bas skyong 'tshal/_de nas ri bo dpal 'bar du lo bcu sgom pa lags/_tshe 'di la snang bzhi'i lam rtags rdzogs par byed pas thugs rje can gyis bskyang du gsol zhus te/_bem gdan zhig ma gtogs thams cad bla ma'i drung du phul $10 /$ 
While these events are not astonishing on their own, when they are examined as an example of how an incarnate lama receives training, they are profoundly significant. In the case of Lekden Dorjé, he becomes a master of the scriptural tradition that defines him as an incarnate lama before his incarnational identity is consummated. These events are also significant because they suggest that he received all of the scriptural authority that was available to him at the very source of the Northern Treasure Tradition. His connection to Śākya Zangpo is obviously essential, but it is also significant that he trained at Mount Trazang. Although the sources remain silent regarding the other students and teachers at the center, there is no reason to doubt that there were others involved in his training that were at least intimately involved with the Northern Treasure Tradition if not the descendent of Gödem Truchen and his original disciples.

The power of the sacred geography of Mount Trazang should also not be underestimated. Not only is this where he becomes a master of the tradition, but it is also here in the heart of the dominion of the Northern Treasures that Lekden Dorjé will eventually realize his identity as Gödem Truchen. The enchanting power of the founder continues to bless the ground where his feet passed so many times. These blessings are particularly meaningful and transformative for those who had a karmic connection with the master. But, the significance of the blessings for those who are actually his reincarnations is hard to understate. Pema Trinlé, the seventeenth century incarnation of the lineage, will also go on a great pilgrimage to these lands in order to reestablish his connection with the sacred geography and blessings of his tradition. 


\section{$\underline{\text { Recognition \& Karmic Relationships between Treasure Revealers }}$}

In the following excerpt, we witness the initial recognition of Lekden Dorjé and Pema Wangyel as incarnations of important figures from Tibet's mythic past. It is interesting that it is not Śākya Zangpo who recognizes their true identities, but another of their masters, Kongchen Rinpoche (kong chen rin po). In Zhung (gzhung), the Ngari Brothers meet with this master who endows them with the treasure teachings of Padma Lingpa. While residing there, the elder master becomes ill and in his dying days reveals important information about the true identity of the Ngari brothers.

The incarnations will work for the benefit of sentient beings. This older lama, [Pema Wangyel], is the rebirth of the sovereign, an emanation of the qualities of King Trisong Detsen. [He] lived in the south a long time ago and benefitted migratory beings as he nourished the teachings of [the Lord]. You, [Lekden Dorjé], are the emanation of the speech of Nanam Dorjé Dujom. ${ }^{127}$

127 Pema Trinlé (padma 'phrin las) (1641-1717), The Biography of Rindzen Lekden Dorjé, 361. Transliteration: de nas sprul pas 'gro don byed pa yin/_bla ma rgan pa 'di khri srong lde btsan gyi yon tan gyi sprul pa mnga' bdag gi skye ba yin/_'gro don lho phyogs su lo snga yod mnga' bdag gi bstan pa gso/_khyed rdo rje bdud 'joms kyi gsung gi sprul pa yin/_ 
The language that is used to discuss the relationship between Lekden Dorjé and Nanam Dorjé Dujom in this passage mirrors the language employed in The Ray of Sunlight to describe the relationship between Gödem Truchen and Nanam Dorjé Dujom. In both cases, the Northern Lords are describes as speech-emanations (gsung gi sprul pa). One of the most informative aspects of this passage, however, is that Lekden Dorjé is first recognized as an emanation of Nanam Dorjé Dujom, not Gödem Truchen. This is surprising in light of the fact that it is now common for the process of recognition to focus more specifically on confirming that there is a connection between the candidate and the previous incarnation. ${ }^{128}$ In this context, identifying the Ngari brothers as emanations of imperial-era figures signifies that the logic of exalted embodiment is being employed to legitimize their roles as treasure revealers.

This passage also reveals that this is not the first time that Pema Wangyel, Lekden Dorjé, and Śākya Zangpo worked together for the benefit of the Buddha's teachings. As an emanation of King Trisong Detsen, Pema Wangyel turns out to be the central figure of the group as his brother and master are emanations of King Trisong Detsen's minister and advisor, Nanam Dorjé Dujom and Gö Pema Gungtsen ('gos pad ma gung btsan) respectively. The relationship between these three patriarchs continues as they each return as stewards of the Northern Treasure Tradition. In the following passage, it is

\footnotetext{
${ }^{128}$ In particular, candidates are routinely instructed to identify items that belonged to them in their previous life. See: Melvyn C. Goldstein (1973), "The Circulation of Estates in Tibet: Reincarnation: Land and Politics.” Journal of Asian Studies 32, no. 3: 445-455.
} 
revealed that Lekden Dorjé was consciously aware that the karmic relationships of his life will continue in the future:

At that time, in his pure vision he saw clearly a prophecy showing how Pema Wangyel, the precious Drigung Rinchen Püntsok, and others [including himself], will be connected through many series of lives. Then, he went to make offerings to [his brother] at Samyé [where he was enthroned]. ${ }^{129}$

Within the context of the overarching analysis of this dissertation that is focused on incarnation lineages, the passage above is important in that it gives us a glimpse into the nature of Lekden Dorjé's relationship with Drigung Rinchen Püntsok ('bri gung rin cen phun tshogs). For most of his life, Lekden Dorjé was near to his brother's side, but after his death, Drigung Rinchen Püntsok fulfills this partnership role. The two of them travel together to Samyé, for example, to reveal additional treasure information related to the cycle that the Ngari brothers had previously uncovered. What is interesting is the statement that Drigung Rinchen Püntsok and Lekden Dorjé will now be connected

129 Pema Trinlé (padma 'phrin las) (1641-1717), The Biography of Rindzen Lekden Dorjé, 364. Transliteration: de dus dag snang du paN chen rin po che dang 'bri gung rin cen phun tshogs sogs skye brgyud du mar 'brel tshul gyi lung bstan gsal ba dang/_bsam yas bar khang na zab gter yod tshul byung/_de nas bsam yas su paN chen rin po cher gdan bzhugs 'bul bar phebs/_ 
through a series of rebirths. While such a statement is surely in part a reflection of the deep connection that was forged between the two masters, it also signifies a major development in the religious imagination regarding high lamas. By this time, everyone that is important in his life is destined to reincarnate and meet again in future lives. The Ngari Brothers have previously been incarnated together as King Trisong Detsen and Nanam Dorjé Dujom during the time of Guru Rinpoche. The future incarnations of Lekden Dorjé would continue to be entwined with the incarnations of his brother, Pema Wangyel, his root lama, Śākya Zangpo, and his vajra friend, Drigung Rinchen Püntsok.

At this point in the investigation, a fair amount of circumstantial evidence has been presented that together forces one to reconsider the nature of this mid-sixteenth century tradition. The Ngari Brothers inherited a strong repertoire of tantric lineages as they learned the family trade from their father. Although they certainly established a strong connection with Śākya Zangpo and the Northern Treasures, one wonders if these new acquisitions came to define their tradition during their lifetime or if their centrality was retrospectively orchestrated by their future biographers. Also, the addition of the Northern Treasures to their repertoire did not disrupt the hereditary, clan-based nature of their tradition. Thus, there is reason to believe that as the elder brother, Pema Wangyel, was being groomed for a leadership position. The superiority of his role in the family practice and his centrality in the relationship with Śākya Zangpo may be reflected in his identification as an emanation of King Trisong Detsen. This perspective is strengthened below as Pema Wangyel's reincarnation is even more clearly presented as a patriarch of the tradition. Nevertheless, tradition maintains that the most important link is that which is forged between Śākya Zangpo and Lekden Dorjé. It is through this connection that the 
scriptural authority of the Northern Treasure Tradition finally returns to the Lords of the Northern Treasures.

\section{Remembering Past Lives}

The final development in the identity of Lekden Dorjé occurs when he once again returns to the natal land of Gödem Truchen and visits Mount Trazang. One of the signs that this is still the epicenter for the Northern Treasure Traditions at this time is that it houses an extensive collection of written materials that draw Lekden Dorjé's attention during his visit. This is also the location where Lekden Dorjé previously pledged himself in service of Śākya Zangpo and where he received reading transmissions for every last verse of the tradition. Furthermore, it is the teachings from this hub of the Northern Treasures that he took into a ten-year meditation retreat that consummated his status as a realized master of the lineage. Now, he returns and consummates his identity as a reincarnation of Gödem Truchen.

Then, he went to Mount Trazang. He resided at the temple called Namjom (rnam 'joms) for several days and pure-visions appeared. He received from the treasury an auxiliary text (cha lag) of the Self-Arising Eight Pronouncements (bka' brgyad rang shar) Cycle [of the Northern Treasures]. It contained a record of teachings given to the sovereign [of the tradition] at the end. Then, he remembered his former lives as Gödem Truchen. Later, he performed such 
activities as moving the treasury [to a better place] and restoring its contents and so forth. ${ }^{130}$

This passage narrates perhaps the most significant events in the life of Lekden Dorjé from the perspective of the future tradition. Not only does he confirm his own status as the reincarnation of Gödem Truchen by recovering the memories of his previous life, he has taken over the stewardship of the collection of scriptures at the epicenter of the Northern Treasure Tradition. This act reflects his status as a recipient of both the scriptural and institutional authority of the tradition that he founded in his previous life.

The manner in which his identity as an incarnate lama is confirmed offers us a unique perspective on the process. As mentioned above, the practice within a robust incarnation lineage is to recognize new incarnations while they are young. The candidates are often required to identify their possessions among a group of items as proof of their true identity. The implicit logic is that one's latent memories can somehow guide the child toward the correct items. In the case of Lekden Dorjé, his latent memories are awakened while reading a text that was reporting upon the activities of his previous life.

${ }^{130}$ Pema Trinlé (padma 'phrin las) (1641-1717), The Biography of Rindzen Lekden Dorjé, 370. Transliteration: bkra bzang du phebs te rnam 'joms lha khang du dag snang shar zhag shas bzhugs/_bka' brgyad rang shar gyi cha lag zhig gter nas bzhes/_di phyis zhabs drung bdag por gnang ba gsan yig tu yod/_rigs 'dzin rgod ldem can gyi sngon gnas gsal bar dran te gter gnas spo ba dang/_gter kha gso dgos sogs mdzad/_ 
In both cases, the consummation of incarnational identity requires a prompt from or about a past life and a feat of memory.

The distinctive element regarding Lekden Dorjé's status as a reincarnation of Gödem Truchen is that he actually recovers the memories of his previous life, which is not a requirement within the current institution of rule by incarnation. This distinction may be grounded in the fact that Lekden Dorjé was already an accomplished master with a long history of visionary experience. When we consider his specific set of skills, the feats of memory that are involved in consummating one's status as an incarnate lama are revealed as strikingly similar to the feats of memory that are involved in treasure revelation, especially when an incarnational or emanational relationship to imperial-era personalities is understood as essential to the process. In both contexts, a relatively small memory - the ownership of a particular item or the location of concealed treasures - has profound implications.

\section{Reunited Sibling: Lekden Dorjé to Trashi Topgyel (Late-16 ${ }^{\text {th }}$ c.)}

In this section, we witness the passage of the authority of the Northern Treasure Tradition from Lekden Dorjé into the hands of Trashi Topgyel (1550-1603). In the following two sections, we examine Trashi Topgyel as the first individual to act as a de facto regent for the emerging incarnation lineage, as he is the lineage holder that links Lekden Dorjé and his reincarnation, Ngakgi Wangpo. Trashi Topgyel performs many important functions for the Northern Treasure Tradition, however, that are also discussed at length in the following sections. In this passage, we witness Trashi Topgyel's rapid success at the feet of Lekden Dorjé. 
Then, when Lekden Dorjé was nearing 100 years of age, the reincarnation of he who was previously Pema Wangyel Lama arrived. [Trashi Topgyel] was born in the Jangpa (byang pa) family of the Yeru (g.yas ru) region [of Tsang]. [Lekden Dorjé first] saw him when it had come time for [the reincarnation of his brother] to seek religious teachings. He was traveling from Mount Chuwo (chu bo) in the direction of Latö (la stod).

As for the manner in which Trashi Topgyel from Jang (byang) remembered his former lives, the holy one activated his latent memories himself. He was invited [to be interviewed by someone in the tradition], and they determined that he was suitable because of his strong connection [with the tradition]. As they were on their way to Jang Ngamring, they met face to face. The master nearly filled [Trashi Topgyel] to the brim with instructions regarding the early translations, the kama, and the terma lineages. Lekden Dorjé appointed Trashi Topgyel as the Lord of the Teachings. ${ }^{131}[\ldots]$

${ }^{131}$ Pema Trinlé (padma 'phrin las) (1641-1717), The Biography of Rindzen Lekden Dorjé, 374-375. Transliteration: de nas dgung lo brgya phrag tsam du nye ba na sngon paN chen rin po che'i sprul sku 'byon par bka' stsal pa de nyid g.yas ru byang ba'i rigs su 'khrungs shing chos bka' btsal ba'i dus la bab par gzigs te chu bo ri nas la stod phyogs su phebs pa 375 dang/_byang nas chos rgyal bkra shis stobs rgyal yang sngon gnas rjes dran gyi tshul du bag chags sad de dam pa 'di nyid spyan 'dren par btang ba rten 'brel shugs kyis 'grig 
Lekden Dorjé indeed gave Trashi Topgyel many prophecies about the future. The northern lord (chos rgyal byang pa) was residing within an expansive dharma assembly that was practicing the early tantras (snga 'gyur rdo rje theg pa) at a place called the Secret Mountain, when Lekden Dorjé raised him to the level of preceptor (mkhan po) and he fulfilled the wishes of all of his disciples and whoever needed taming. When he reached the age of 113 , for a moment he completely knew his disciple of this domain. ${ }^{132}$

The narrative above suggests that Lekden Dorjé did not simply "select" Trashi Topgyel to be his successor; he first recognizes Trashi Topgyel as the reincarnation of his brother, Pema Wangyel. He then subjects him to rigorous and thorough training that not only empowers him as a full lineage holder and patriarch of the tradition, but also

ste byang ngam ring gi phyogs su phebs te zhal mjal zhing/_snga 'gyur bka' gter gyi gdams ngag phal che ba bum pa gang byo'i tshul du mdzad de chos kyi bdag por bskos/_

${ }^{132}$ Pema Trinlé (padma 'phrin las) (1641-1717), The Biography of Rindzen Lekden Dorjé, 375. Transliteration: ma 'ongs lung bstan yang mang du gnang/_chos rgyal byang pas gsang ri zhes par snga 'gyur rdo rje theg pa'i chos gra rgya cher btsugs pa'i mkhan po mdzad cing gang 'dul gdul bya'i re ba bkang nas dgung lo brgya dang bcu gsum du phebs pa'i tshe re zhig zhing 'di'i gdul bya rdzogs par mkhyen nas/_ 
awakens his latent memories of his life as Pema Wangyel. While this passage leaves little doubt that Trashi Topgyel is the legitimate successor of Lekden Dorjé, it says nothing about the relationship between the tradition that is transported to Central Tibet and the tradition that remains at Mount Trazang. Nevertheless, it does confirm that the "tradition" that was inherited by Trashi Topgyel contained a combination of kama and terma lineages. Still, it would be interesting to know how central the Northern Treasures actually were within that tradition.

The question of the importance of the Northern Treasures, with respect to the other kama and terma transmissions that were bound together in this tradition, is further complicated if one considers all of the patriarchs of the tradition rather than just the Northern Lords. In fact, Śākya Zangpo, Lekden Dorjé, and Trashi Topgyel were all lineage masters of a variety of tradition including the Northern Treasures, were all recognized as incarnations of previous figures from Tibetan history, and were all accomplished treasure revealers. And, as I argued above, there is at least circumstantial evidence to suggest the Pema Wangyel was also a patriarch of the tradition, and he possessed all of these same qualities. Moreover, there is nothing to indicate that Śākya Zangpo or Trashi Topgyel were to be temporary authority figures like regents. This suggests that these three categories were consciously linked to matters of succession in this sixteenth century Nyingmapa tradition. One could argue that throughout this stretch of time, the eldest living incarnation among the three lineages took on the leadership responsibilities of the lineage. These shared qualifications confirm the centrality of treasure scriptures in the tradition, but the diversity involved in the incarnational identities of the patriarchs may also reflect the shared importance of various treasure 
cycles within this tradition. At this point, there is little evidence to suggest that the Northern Lords or their treasures were actually the supreme focal point of the tradition.

With respect to the developing incarnation lineage, however, it is also very significant that neither Śākya Zangpo nor Lekden Dorjé passed the lineage on to their clansmen. While this was not unheard of in the Order of the Ancients, both Sāaya Zangpo and Lekden Dorjé were from strong families of tantric entrepreneurs, and thus one may speculate regarding the nature of this fact. As discussed in more detail below, this trend is not observed when Trashi Topgyel selects his own successor.

Another significant characteristic that Lekden Dorjé and Trashi Topgyel share is that they were not simply recognized as reincarnations; both managed to activate their latent memories and were thus capable of remembering their past lives. Future research may reveal if this was a trend in the sixteenth century or simply a coincidence. But, in the case of these two figures, their recovered memories could be potentially linked to a number of shared characteristics: adult recognition, experience, and treasure activities.

\section{The Brother-Father Regent \& the Incarnate Son: From Trashi Topgyel to Ngakgi Wangpo (Early-17 ${ }^{\text {th }}$ c.)}

In this section, we analyze how Ngakgi Wangpo was identified as a reincarnation of Lekden Dorjé and the profound changes that occur after the tradition is relocated to central Tibet. This first excerpt from The Guru Trashi has been selected as it demonstrates that not only did Lekden Dorjé select his own successor, Trashi Topgyel, he is also credited with predicting who will be his father in his next life. 
Once, while Trashi Topgyel was uttering the oral lineage of the five intermediate states according to the Kunzang Gongpa Zangtel (kun bzang dgongs pa zangs thal), which is one of the many profound spiritual teachings received from Lekden Dorjé at a Jang Monastery (byang theg mchog gling). Lekden Dorjé expressed his desire to demonstrate [life's] final deed. It seems that no sooner than he had said that, he went into [the meditative state called] Direct Transcendence (thod rgal). Then, Trashi Topgyel stood up in the middle of the religious assembly and joined his palms together [beseechingly] and verbally supplicated [the superior lama] by saying: "Please do not abide in that final state beyond all suffering. If you do wish to transmigrate to the pure realms, [know] that we need for the supreme incarnation to arrive quickly!" On account of Lekden Dorjé's unchanging adamantine pronouncement, which was: "I am not able to remain [long in this body]. Since you are held in such high regard, the sovereign will be born as your own son." ${ }^{133}$

133 Guru Trashi (gu ru bkra shis) (b. $18^{\text {th }}$ c.), 674-675. Transliteration: rig 'dzin ngag gi dbang po ni/_sngar chos rgyal bkra shis stobs rgyal gyis byang theg mchog gling du rig 'dzin mnga' ris pa chen po la zab chos mang du gsan pa'i kun bzang dgongs pa zangs thal gyi bar do lnga'i snyan brgyud gsung ba'i skabs mdzad pa tha ma ston par bzhed pa'i gsung gya ma do 'dra ba thod rgal du byon pas/_chos rgyal dbang po'i sdes chos gral gyi dbus su bzhengs te thal mo sbyar nas/_rab tu mya ngan las mi 'da' bar bzhugs pa dang /_gal srid zhing khams 'pho bar bzhed gt675 na mchog gi sprul sku myur du phebs dgos 
The link between Trashi Topgyel and Ngakgi Wangpo is an interesting moment in the development of the incarnation lineage of the Northern Lords. Retrospectively, because there is only one patriarch between the incarnations of Lekden Dorjé and Ngakgi Wangpo, Trashi Topgyel acts as a de facto regent that safeguards the authenticity and potency of the tradition between incarnations. Even though Trashi Topgyel was not a regent, but a full lineage patriarch, his actions represent a significant step in the development toward a robust example of rule by incarnation that often employs regents between incarnations.

zhes zhal gyis gsol ba btab pas/_ nga da res bsdad pas yong ba med/_khyed de tsam gyis gtsigs che na bdag po rang gi bur skye ba len no zhes pa'i rdo rje'i gsung 'gyur ba med par brten/_yab rig 'dzin chen dbang po sde'i nyid dang /_yum 'phyong rgyas za hor gyi gdung las lcam yid 'dzin dbang mo legs sbyar gyi skad du man+d+har red+drAr 'bod pa de'o/_sku 'khrungs pa'i yul ni zhang yul du ngo tshas skye mi rung ba'i thugs dogs kyis gangs can gyi ljongs 'dir chos rgyal mes dbon rnam gsum gyi dus/_dbus gtsang ru bzhir grags pa las g.yon ru'i sa'i cha grwa phyi ma'i phu chos lding dgon par 'phags pa'i yul du bI ra zhes pa rnam gnon du grags shing /_bod yul 'dir rgya nag gi gtsug lag ltar lcags pho 'brug gi lo la ngo mtshar ba'i ltas dang bcas te sku bltams/_na tshod phra mo'i dus nas thugs sgam zhing dkyel che ba byis pa tha mal gyi rol rtsed ye mi mdzad cing /_ 
In so far as incarnation lineages are akin to kingships and concerned with temporal dominion and sovereignty, a regent is of paramount importance. In the normal rules for the passage of kingship from one person to another, it is entirely possible that a regent would be unnecessary. There are various scenarios for kingship that could result in an heir that is in his or her majority, whether that person is a son, daughter, brother, sister, etc. If, however, the rightful heir to the throne is too young, then a regent of some sort usually rules in that persons stead. The reason is training. There are matters of state that need to be decided that are not to be left to the opinions of children. Furthermore, within a dynasty there is a transmission, of sorts, of knowledge about how the kingdom, whatever its size, should be ruled. What are the reoccurring problems of the realm and how shall they be addressed. Thus, there is a lineage of knowledge that must be maintained from one generation through to the next. Furthermore, the realm must function. Important decision cannot be put off until the king or queen is mature enough to deal with the situation.

Incarnation lineages face similar problems. There is, of course, concern with the rightful identification of the new lord. This will be important later in the tradition, but not for the father-regent himself. Because he is the reigning master of the Northern Treasures Tradition, no other authority then his own is required to confirm his son as the reincarnated lord. Unlike the transition between Gödem Truchen and Lekden Dorjé, there is only one individual to act as regent between Lekden Dorjé and Ngakgi Wangpo. According to the latter's biography, Ngakgi Wangpo's training started at a very young age and the father and son had a relationship that lasted for many years. This relationship would have allowed for the proper transmission of empowerments from father to son. 
The role performed by Trashi Topgyel is interesting in that on the one hand it marks a clear movement toward a robust incarnation lineage, while on the other hand it relies on the traditional Nyingmapa family-practice style of transmission. Because the next incarnation of Nanam Dorjé Dujom happens to be his own son, the transition of power represents a not too subtle combination of emerging power structures and the ancient traditions of the Nyingmapa religious entrepreneurs that passed the secrets of their craft to their children. One might even consider the recognition of his own son as a choice fostered by its convenience, if it were not for the dramatic scene in which Lekden Dorjé predicts his own birth as the child of Trashi Topgyel. One fact that is resoundingly clear is that serial incarnation is not employed by Trashi Topgyel to thwart clan-based power. In fact, by recognizing his own son as an incarnation of his master, he effectively consolidates power in his family.

\section{Contradictions \& Consequences}

Unfortunately, there is reason to doubt both that Lekden Dorjé appointed Trashi Topgyel as his successor and that Lekden Dorjé predicted that he would be reborn as Trashi Topgyel's son. Tradition maintains that both Lekden Dorjé and his father, who was an accomplished tantric master, lived to the ripe old age of 113. If this is maintained as fact, then Lekden Dorjé was born in 1512 and did not pass away until the year 1625 . We would therefore expect that it was around 1612 when Lekden Dorjé first recognized Trashi Topgyel as a reincarnation of his brother and began grooming him as his successor because the biographical sources say these events began when Lekden Dorjé was approaching his centennial birthday. It would also be expected that it was in the year 
1625 when Trashi Topgyel witnessed the death of his master Lekden Dorjé and received the prognostication that his master would return to earth quickly as his own son.

Trashi Topgyel himself is held to have lived for 53 years from 1550 until 1603. If these dates are maintained as accurate, then Trashi Topgyel died before Lekden Dorjé reached his one hundredth year and could not have been appointed at that time as his successor. He also could not have been present at the death of Lekden Dorjé and received his predictions because he had already passed from human form two decades prior to this event. To further complicate the situation, Ngakgi Wangpo is thought to have lived for 59 years from 1580 until 1639. Thus, it would appear that there were 45 years during which time the Lord of the Northern Treasures occupied two bodies at once: Lekden Dorjé and Ngakgi Wangpo. The following table is intended to show the impossibility of maintaining that all of the dates and events narrated in the biographical sources are accurate.

\section{The Traditional View of the Lifespan of Lekden Dorjé}

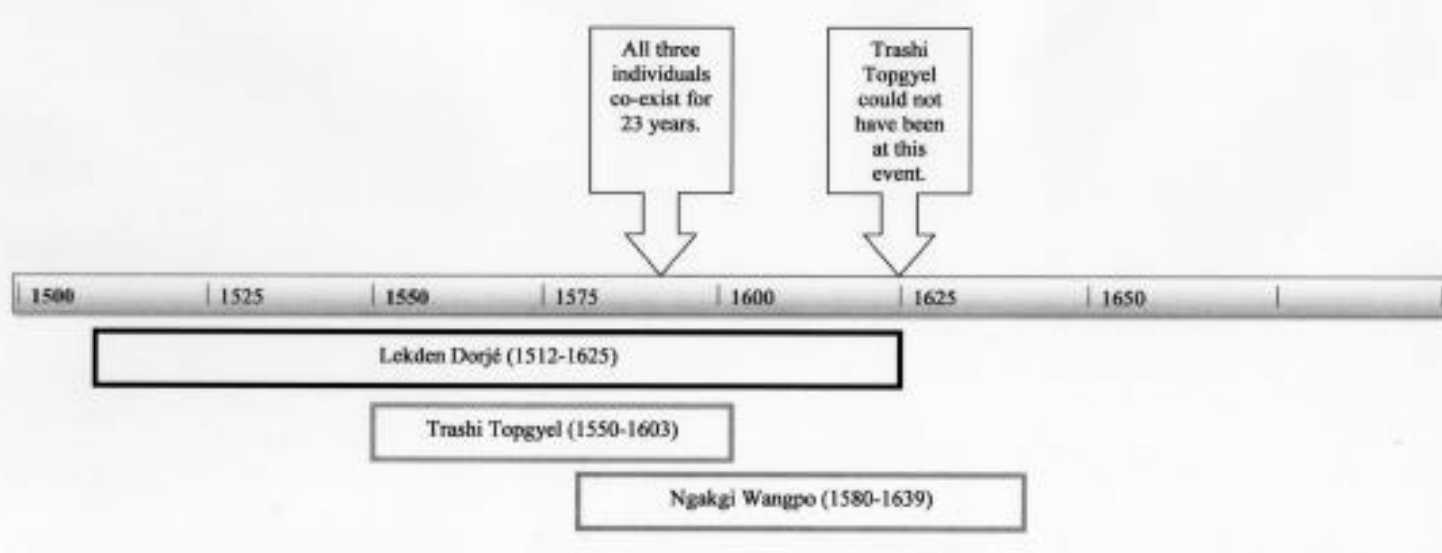


These contradictions leave us with two interpretive choices relevant to the current discussion: Either the lifespan of Lekden Dorjé has been grossly exaggerated or the veracity of the key events that link the Northern Treasure Tradition to Trashi Topgyel and Ngakgi Wangpo must be called into question. I would not normally feel that it is necessary to doubt that someone lived to be 113 years of age. Although it is an extremely long time to live, perhaps double the lifespan of his contemporaries, it is still possible. Within the present context, maintaining those dates would call into question the continuity linking the religious tradition headed by Śākya Zangpo and Lekden Dorjé in Jang Ngamring and the religious institution that is established by Trashi Topgyel and continued by Ngakgi Wangpo in Central Tibet. Admittedly, it was my initial intuition when I first began analyzing this tradition years ago that all of the incarnational linkages backward in time from Trashi Topgyel were all fabricated retroactively. After reading volumes of biographical accounts of the incarnations of this tradition, however, I have been sufficiently convinced that Lekden Dorjé understood himself as an incarnate lama that was intimately involved with the leadership of the Northern Treasure Tradition. I have therefore decided to experiment with changing the date of Lekden Dorjé's passing in order to render the events connecting the two traditions possible. The most obvious time to truncate Lekden Dorjé's lifespan is in the year 1580, which is the year of the birth of his reincarnation. The following table shows the alternative dates. 


\section{Alternative View of the Lifespan of Lekden Dorjé}

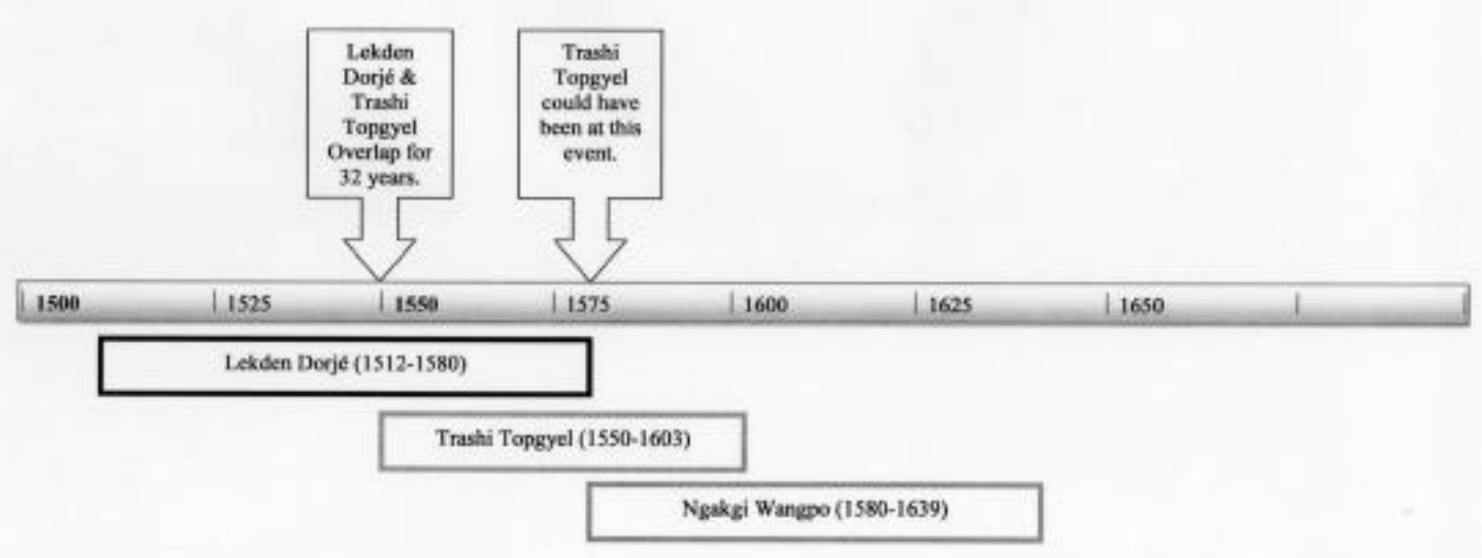

These proposed dates allow for a 32 year overlap of the lives of Lekden Dorjé and Trashi Topgyel, which is a sufficient amount of time for the key events that narrate the transfer of power from the former to the latter. It would also mean that Trashi Topgyel was 30 years of age when Lekden Dorjé made his prognostication regarding his own rebirth and passed away. The only thing sacrificed is the traditional belief that Lekden Dorjé lived to be 113 years of age like his father before him. I suspect that the significance of living 113 years is probably a remnant of an older legitimization strategy within the Order of the Ancients. In the end this is a small sacrifice that secures the legitimacy and continuity of the Northern Treasure Tradition of Central Tibet.

\section{Recognition and Training of the Incarnation}

Ngakgi Wangpo is the first of the Northern Lords to be recognized as a reincarnation while still a child. The following passage from the Guru Trashi describes the process of by which his incarnational identity is confirmed. Although he must still 
perform small feats of memory to prove himself, Ngakgi Wangpo is not expected to lucidly remember his past live.

[His] father was Trashi Topgyel himself and the mother was from a lineage of Chongyé Zahor ('phyong rgyas za hor). Her name was Cham Yidzin Wangmo (lcam yid 'dzin dbang mo), which in Sanskrit is pronounced Mandharedrā $(\operatorname{man}+d+$ har $\operatorname{red}+d r A)$. Regarding the [sovereign's] birth place, although there was doubt regarding the suitability of [his] humble origins in (zhang yul), it has been known since the time when the three ancestral religious kings were here in the land of snow that [someone] named Bīra (bI ra) [would be born] in a noble land in a monastery called Drachi Mepu Chöding (grwa phyi ma'i phu chos lding), someplace in the left horn among what are known as the four horns of Central Tibet in the year of the Iron Dragon. And, [the sovereign] was born together with miraculous signs in the year Iron Dragon in what appears to be a Chinese temple in the land of Tibet. From the time [he] was in the early stages of life, he was reserved and spacious, not ever playing like normal children.

Once he was able to speak and demonstrate actions that implied that he had awakened the mental imprint of [his former life as] Lekden Dorjé, his father, Trashi Topgyel, understood [his son] as the one to be cherished as "my lama's rebirth" and the son's name was then known as the Blessed Lama (zhabs drung bla 
ma). He recognized many associates, material possessions and statues [that belonged to Lekden Dorjé]. ${ }^{134}$

One of the benefits of being recognized at a young age and after such a short period of time is that training can begin quickly with tutors that had direct contact with the previous incarnation. In addition, the early training of an incarnate lama helps to ensure that he or she will be able to receive the encyclopedic volume of reading

${ }^{134}$ Guru Trashi (gu ru bkra shis) (b. $18^{\text {th }}$ c.), 675. Transliteration: nga da res bsdad pas yong ba med/_khyed de tsam gyis gtsigs che na bdag po rang gi bur skye ba len no zhes pa'i rdo rje'i gsung 'gyur ba med par brten/_yab rig 'dzin chen dbang po sde'i nyid dang /_yum 'phyong rgyas za hor gyi gdung las lcam yid 'dzin dbang mo legs sbyar gyi skad du man $+\mathrm{d}+$ har red+drAr 'bod pa de'o/_/sku 'khrungs pa'i yul ni zhang yul du ngo tshas skye mi rung ba'i thugs dogs kyis gangs can gyi ljongs 'dir chos rgyal mes dbon rnam gsum gyi dus/_dbus gtsang ru bzhir grags pa las g.yon ru'i sa'i cha grwa phyi ma'i phu chos lding dgon par 'phags pa'i yul du bI ra zhes pa rnam gnon du grags shing / bod yul 'dir rgya nag gi gtsug lag ltar lcags pho 'brug gi lo la ngo mtshar ba'i ltas dang bcas te sku bltams/_na tshod phra mo'i dus nas thugs sgam zhing dkyel che ba byis pa tha mal gyi rol rtsed ye mi mdzad cing / _rig 'dzin legs ldan rdo rje'i bag chags sad pa'i mdzad pa ston pa dang gsung 'byon pa la brten/_yab dbang po'i sdes nga'i bla ma'i sku skye zhes gces par bzung pas mtshan zhabs drung bla mar grags/_phyag rdzas dang sku dang 'khor mang po la ngos 'dzin mdzad/_ 
transmissions and empowerments that are often maintained by lamas in charge of large scale religious institutions. The following passage offers some details regarding Ngakgi Wangpo's early training.

The hair cutting ceremony was done in the presence of the glorious Drigung Chögyel Püntsok and [the boy] came to bear the name Ngakwang Rindzin Dorjé Chögyel Tenpé Gyeltsen Pel Zangpo (ngag dbang rig 'dzin rdo rje chos rgyal bstan pa'i rgyal mtshan dpal bzang po). He took his bodhisattva vows and was initiated (dbang bskur) at the rank of supreme spiritual heir (rgyal sras sems dpa' mchog).

Since he had maintained the vows of renunciation in his past life as Lekden Dorjé, his father, Trashi Topgyel, relying upon innumerable tutors, provided for him as if filling a vase to the brim with profound religious teachings that present the difficult points of the meaning of religious facts. Thus, in this lifetime, as he was in alignment with many lamas, he couldn't help but obtain a repository of wealth. Usually, the items were accepted by the father. ${ }^{135}$

${ }^{135}$ Guru Trashi (gu ru bkra shis) (b. $18^{\text {th }}$ c.), 675. Transliteration: dpal 'bri gung pa chos rgyal phun tshogs la gtsug phud phul bas mtshan ngag dbang rig 'dzin rdo rje chos rgyal bstan pa'i rgyal mtshan dpal bzang por gsol/_byang chub sems dpa'i sdom pa gnang ste rgyal sras sems dpa' mchog gi go sar dbang bskur/_sku tshe sngon ma legs ldan rje'i dus su bya bral gyi brtul zhugs bzung ste yongs 'dzin grangs med pa bsten nas chos phyir dka' 
As for the treasure teachings that were invited [into this world] by those that are known as the one hundred and eight great treasure revealers, he received some of them thoroughly, while some others he received in just the appropriate level of specificity. Yet, everything that he heard he not only listened and thought about, but also ardently engaged through the gates of contemplation and meditation.

Then, he did many visualization retreats that lasted five or six months [each] in many pilgrimage sites for religious practice, such as Yarlung Sheldrak (yar lung shel brag), and other locations above and below Chongyé ('phyong rgyas), such as Namkha Dzö (nam mkha' mdzod). Thus, he was bestowed many gifts of voices and visions of many [different] tutelary deities and protectors. No matter what type of possession by harmful spirits that are difficult to subdue, as soon as [Ngakgi Wangpo] would bless them, the spirits would be liberated. ${ }^{136}$

ba mdzad pa'i zab chos rnams yab dbang po'i sdes bum pa gang byo'i tshul du gnang ba la brten/_sku tshe 'dir bla ma mang po la bltos ma dgos par nor gyi bcol po len pa ltar chos rnams phal cher yab la gsan pas/_

${ }^{136}$ Guru Trashi (gu ru bkra shis) (b. $18^{\text {th }}$ c.), 675. Transliteration: gter ston chen po brgya rtsa brgyad du grags pa de rnams kyis spyan drangs pa'i gter chos las la la'i gter chos yongs rdzogs dang /_'ga' zhig gi gter chos bye brag ci rigs gsan zhing /_gsan pa kun kyang thos blo tsam min par bsam pa dang sgom pa'i sgo nas nan tan du mdzad/_yar lung 
In light of his early recognition and training that included the Northern Treasures, Ngakgi Wangpo was likely aware of his identity as a reincarnation of Lekden Dorjé for the majority of his life. ${ }^{137}$ Therefore, his own experience of being an incarnate lama was fundamentally different than his predecessor's. Lekden Dorjé did not encounter the Northern Treasures until he was in his majority. Thus, any sense he had of being a reincarnation of anyone in particular developed later in life. For Ngakgi Wangpo, however, his status as a reincarnation of Gödem Truchen and Lekden Dorjé was a fundamental part of his identity.

Conversely, Ngakgi Wangpo is the first patriarch of the tradition since Săkya Zangpo that does not appear to be an active treasure revealer. While there are no treasures that are attributed to this figure, in The Hundred Tertöns, Kongtrül Rinpoche describes him as what appears to be an honorary treasure revealer:

shel brag sogs sgrub pa'i gnas chen mang po dang /_'phyong rgyas yar rgyab nam mkha' mdzod sogs su zla ba lnga drug sbrel ba'i bsnyen sgrub lan mang du mdzad pas/_yi dam chos skyong du ma'i zhal gzigs pa dang gsung gi gnang ba du ma bstsal zhing /_gang gis kyang thul bar dka' ba'i gdon gyis btab pa'i rigs la byin rlabs mdzad pa tsam gyis rang grol du 'gyur/_

${ }^{137}$ For a discussion of how one's self perception is affected by being an incarnate lama, see: Janet Gyatso (1998), Apparitions of a Self: The Secret Autobiography of a Tibetan Visionary(Princeton: Princeton University Press), 211-242. 
Although it is certain that Ngakgi Wangpo was a chakravartin of profound terma, in Shazukpa Tashi Namgyal's History of Terma it is written:

Although Ngakgi Wangpo did discover a few profound termas, he never revealed them because of his great appreciation for earlier termas.

Similarly, from the Testament of Padma:

Sometimes they will not reveal them, but keep the dharma of old termas.

That is what Ngakgi Wangpo did. In his upholding, keeping, and dissemination of the old termas, he was peerless. ${ }^{138}$

Ngakgi Wangpo's reincarnation, Pema Trinlé, is also not a treasure revealer, but for whatever reason, he does not earn an honorary passage in The Hundred Tertöns. Further research is required to determine if this pattern is repeated by other incarnation lineages that have roots in the treasure traditions. The Northern Lords may be a special case, since they eventually become the patriarchs of a Nyingmapa monastic institution.

${ }^{138}$ Jamgön Kongtrül Lodrö Tayé ('jam mgon kong sprul blo gros mtha' yas) (1813-1899), The Hundred Tertöns: A Garland of Beryl: A Brief Account of Profound Terma and the Siddha Who Have Revealed It. Trans. Yeshe Gyamtso (New York: KTD Pub., 2011), 246-247. 


\section{The Foundation of the Community and the Estate}

From the perspective of the Northern Treasure Tradition, Trashi Topgyel is credited with having relocated the seat of the tradition from Mount Trazang in Jang to Dorjé Drak in Central Tibet near the end of the sixteenth century. This is not a small accomplishment considering the fact that Dorjé Drak develops into one of the six "mother monasteries" of the Order of the Ancients in the mid-seventeenth century. ${ }^{139}$ While respected as a powerful tantric specialist capable of securing wealthy patronage, he achieved a degree of infamy for releasing his deadly wrath upon a political foe. Tradition maintains that his malfeasance was the impetus that forced Trashi Topgyel into the itinerant lifestyle that eventually transported the Northern Treasures to their destiny in Central Tibet.

For the sake of public appearance, [Trashi Topgyel] was disgraced by [the regional leader and his own confession] and forced to move to Central [Tibet]. Although this is how it looked publicly, the real purpose of the move was to open the way for his enlightened activity in the central region [of Tibet]. The intention was for there to be a meaningful link that would bring about the expansion of his religious lineage and teachings. He resided wherever was suitable around Chongyé until he came to Gyaha Kaling Tseyen in Domé (mdo smad rgya ha ka ling rtse yan). In those days he maintained [a group] of non-sectarian disciples

${ }^{139}$ This subject is discussed in more detail in Chapter Four. 
and established a rather pure religious encampment. The community bore the name Guru Pema Ewam Chokgar (gu ru pad+ma'i e waM lcog sgar).

All of the specific religious activities [that were practiced in his community] became the principle [methods] of the Northern Treasure Tradition. Because he established this continuity of teachings and practices, [the encampment] flourished. [This encampment] was the seed [that blossomed into] the Tupten Dorjé Drak (thub bstan rdo rje brag chos sde) monastic center.

In that [community], Lekden Dorjé himself intentionally arrived to be born as a son of Trashi Topgyel and Zahor Lacham Yidzin Wangmo (za hor lha lcam yid 'dzin dbang mo) as soon as he passed from his body. His name was Ngakgi Wangpo, the one who established Tupten Dorjé Drak. ${ }^{140}$

${ }^{140}$ Guru Trashi (gu ru bkra shis) (b. $18^{\text {th }}$ c.), 674. Transliteration: rig 'dzin chen po dbang po'i sde ni/_g.yas ru byang gi char mi nyag stong khun gyi rgyal brgyud du 'khrungs/_phrin las rnam pa bzhi la dbang bsgyur ba dang /_rang skal zab mo'i gter la spyod tshul sogs gong du smos pa ltar lags shing /_gzhan gyi snang ngor sde pa zhing bshags pa sogs kyis zhabs 'dren zhus pa la brten dbus su phebs gnang lta bu la/_don du dbus phyogs su 'phrin las kyi sgo bye bas chos brgyud dang bstan pa 'phel rgyas 'byung ba'i rten 'brel la dgongs nas 'phyong rgyas yar rgyab rnams su ci rigs bzhugs shing mdo smad rgya ha ka ling rtse yan la phebs nas phyogs bral gyi gdul bya skyong ba'i dus su chos sgar dngos gtsang zhig mdzad nas gu ru pad+ma'i e waM lcog sgar du mtshan gsol te bskyed rdzogs sgrub 'phrin phyag bzhes mtha' dag byang gter gtso bor gyur ba'i bshad 
When analyzing these events from the perspective of its incarnation lineage, the establishment of the religious community in Central Tibet is of great importance. There is evidence that from the time of Śākya Zangpo through to Ngakgi Wangpo, the patriarchs of the Northern Treasure Tradition were largely itinerant practitioners travelling throughout the Tibetan Buddhist realm in search of patronage. The establishment of the estate is a major development because the future incarnations are not only the principal lineage holders of the Northern Treasure Tradition, but also the abbots of the Dorjé Drak Monastery. In fact, the primary title of the incarnation lineage, the Wisdom-Holders of Dorjé Drak, reflects the fact that their seat eventually becomes an essential part of their identity.

The relocation of the epicenter of the Northern Treasure Tradition from Jang Ngamring to Central Tibet leads the historians of the tradition to emphasize the continuity of the religious community. The characterization that is developed in The Guru Trashi portrays Trashi Topgyel as a Moses-like figure leading a wandering practice-

sgrub kyi rgyun btsugs pas dar rgyas su byung ba ni thub bstan rdo rje brag gi chos sde'i sa bon lta bu yin no/_der bdag chen rin po che dbang po'i sde dang za hor lha lcam yid 'dzin dbang mo gnyis kyi sras su rig 'dzin legs ldan rje nyid sku 'phos ma thag pa'i skye bar bsam bzhin du byon pa ni rig 'dzin ngag gi dbang po yin te thub bstan rdo rje brag gi chos sde thog mar 'debs po ni 'di nyid yin no/_ 
based community through the Tibetan Landscape before settling for good in Central Tibet at Dorjé Drak. Ngakgi Wangpo is considered the first abbot of the monastic community that forms there. While this narrative is not grossly inaccurate, it oversimplifies the situation while also overemphasizing the continuity of the religious community.

Our understanding of the development of Dorjé Drak is greatly enriched by recognizing it as the Central Tibetan base of operations for Trashi Topgyel and his extended family. Based on the excerpts below, we can deduce that after a lifetime of itinerant wandering, Trashi Topgyel resided at Dorjé Drak surrounded by his family.

In Rama Gang (ra ma sgang), [Ngakgi Wangpo's] younger brother, Rindzin Trinlé Namgyel Pönlop (rig 'dzin 'phrin las rnam rgyal dpon slob), came to welcome him. He met his relative, and then they assembled and gave him an extensive feast at Dorjé Drak. As for the lineage of past saints, however, he thought that his nephew Wön Rinpoché (dbon rin po che) had not been a great custodian [of the estate in his absence]. And thus, there had been a slight violation because of this and other offences. ${ }^{141}[\ldots]$

\footnotetext{
${ }^{141}$ Guru Trashi (gu ru bkra shis) (b. $18^{\text {th }}$ c.), 678. Transliteration: ra ma sgang du gcung rig 'dzin 'phrin las rnam rgyal dpon slob kyis bsu ba la phebs sku mched mjal 'dzom gnang nas rdo rje brag tu gzhi len dang shang len rgyas par mdzad/_'on kyang rje gong ma'i gdung la dbon rin po ches do dam che ba ma byung dgongs pa sogs kyi re 'khang la brten pa'i 'gal 'dzol cung zad byung /_
} 
Then he went to stay together with his relatives. The minister Depa Topgyelwa (sde pa thob rgyal ba) from Tsang diminished in health. So, Rindzin Trinlé Namgyel's (rig 'dzin 'phrin las rnam rgyal) insistent invitation arrived, and the master departed. [The master] reversed his health without fail. But as soon as he started on the path, [the sick person] transmigrated to the Buddha-field. The lord himself sat and gathered himself at the Drakha (brag kha). Even though he was not able to meet him face to face, he performed the liturgy that was desired.

[The master] made renovations at the golden tomb of the glorious Trashi Topgyel and did the spell-scroll consecration. Just after having done that, he decided to reside at his own Dorjé Drak. Then, Yölmopa Tenzin Norbu and Zurchen Chöying Rangdröl and other students indeed arrived. All of the important people of the main Tibetan areas, such as Sakya, Drigung, and Nédong (sne gdong) paid him the highest honors. ${ }^{142}$

${ }^{142}$ Guru Trashi (gu ru bkra shis) (b. $18^{\text {th }}$ c.), 679-680. Transliteration: de nas sku mched lhan cig tu bzhugs/_gtsang nas gt680 sde pa thob rgyal ba bsnyung par/_rig 'dzin 'phrin las rnam rgyal gdan 'dren nan cher byung ste phebs pas/_rong gi chab tshan ma 'phrod par sku khams log ste 'phrang 'gor phebs tsam la zhing khams 'phos/_rje nyid brag khar bzhugs pa dang 'grig nas ngos kyis zhal mjal ma thub kyang dgongs pa rdzogs thabs rgya cher mdzad/_dpal bkra shis stobs rgyal gyi gser gdung la zhig gso dang gzungs bzhugs rab gnas mdzad de/_di tsam nas rdo rje brag rang du bzhugs gtan chags/_yol mo sprul sku bstan 'dzin nor bu dang zur chen chos dbyings rang grol sogs slob ma rnams kyang 
In the above passages, it is evident that Ngakgi Wangpo's family is residing at Dorjé Drak. He meets his brother there, and his cousin is responsible for the affairs of the institution, whatever they may have been. As the practitioners of this generation were lay specialists following many customs of the ancient Nyingmapa, we would expect for other family members to be present as well (e.g., mothers, wives, daughters), but none others are mentioned. Although he expresses disapproval regarding the manner in which his cousin has managed the estate, Ngakgi Wangpo does not take control of the property until after his father dies. This suggests that the community at Dorjé Drak at this time was still under the general authority of Trashi Topgyel's clansmen. There is no clear indication that there is any sort of permanent community of practitioners residing there other than the members of the family. This, of course, does not mean that there wasn't a larger religious community there at the time, but it is likely that any followers that were there must have been few enough to escape mention.

byon/_sa skya/_bri gung /_sne gdong sogs kyis gtsos pa'i bod yul gyi mi chen che dgu thams cad kyis ma btud pa med de kun gyis gtsug tu bkur/_yang khams phyogs su ma phebs gong gi snga thog cig rong bde skyong pas gdan drangs/_chibs las babs pa dang mnyam du rdo la zhabs rjes gsal bar byung zhing /_rdo rje brag gi ltag sgo'i rdo la zhabs rjes gsal bar bzhag pas sku 'khor 'dras 'di ltar snang zhes zhus pas/_ 
Ngakgi Wangpo continues his itinerant lifestyle until the death of Trashi Topgyel. At this time, he returns to Dorjé Drak and presumably takes control from his cousin. At this point, he reestablishes his connection with Tenzin Norbu, the third incarnation of Sákya Zangpo's lineage, and grooms him to act as a regent after his death. This decision is significant because there were already relatives at hand who could have been selected to take control of the real estate holdings. By naming Yölmopa Tenzin Norbu as the regent, however, Ngakgi Wangpo not only called upon the precedent for leadership set by Sankya Zangpo, but also ensured that the property would become a possession of the incarnation lineage rather than an estate belonging to a Nyingmapa family of lay practitioners. Thus, he effectively transferred the holdings from his blood relatives to the incarnation lineage.

Like that, over the preceding two or three years, Ngakgi Wangpo himself entrusted [key items of authority] to the Yölmopa incarnation. [...] On the tenth day of the third month of the Earth Rabbit year, from a state of having an unseen illness he himself planted that night a repentance that he had not previously done and much advice for the present and the future in a collection of excerpted chapters. Then, he did such things as dedicate [himself] to complete and virtuous enlightenment. Then, having gone to his private chambers, he laid out his form body (gzugs sku) and then he temporarily gathered himself in the expanse of dharma. Thus, there were many amazing signs and at the time of the cremation, there were such occurrences as a spiraling rainbow and white flowers that were the size of a crane's eggs, rained down from the heavens. 
Then, the Yölmopa incarnation took on the responsibilities [of the lineage]. [He] completed a great memorial service and constructed a golden statue of the great sage as an external support. He also performed various tasks, such as a consecration by means of three practice cycles (sgrub skor gsum). And having completed what needs to be done after [a great one] departs like that, Yölmopa Tenzin Norbu himself resided in the monastic seat [as head lama] and fulfilled the wishes [of the master's] disciples without bias. In this way, Ngakgi Wangpo initially established Tupten Dorjé Drak and was the first in the succession of abbots. I have narrated in detail only a small part of this history. ${ }^{143}$

143 Guru Trashi (gu ru bkra shis) (b. $18^{\text {th }}$ c.), 680-681. Transliteration: de ltar rig 'dzin ngag gi dbang po 'di nyid kyis lo gnyis gsum tsam gyi sngon nas/_yol mo sprul pa'i skur gter rdzas bka' rgya rnams rtsis len dgos tshul dang / [... _sa yos nag pa zla ba'i tshes bcu'i nyin snyun mngon gyur med pa'i ngang nas 'phral yun gyi slob ston mang po dang /_sngar mi mdzad pa'i bshags rgyud le'u khol phyung tshogs su de nub rang btsugs nas dge ba rdzogs byang du bsngo ba sogs mdzad/_gzims chung du phebs nas gzugs sku'i bkod pa gt681 re zhig chos kyi dbyings su bsdu bar mdzad pas ngo mtshar ba'i ltas du ma dang /_gdung bzhi ba'i dus 'ja' 'od 'khyil ba dang me tog dkar po khrung khrung gi sgo nga tsam gyi char babs pa sogs byung /_ de nas rig 'dzin yol mo sprul pa'i skus thugs khur bzhes te dgongs rdzogs rgya cher bsgrubs shing phyi rten du thub chen gyi gser sku bzhengs/_sgrub skor gsum gyi sgo nas rab tu gnas pa sogs mdzad/_de ltar gshegs rjes kyi bsgrub dgos rnams grub nas yol mo sprul sku bstan 'dzin nor bu stobs ldan shug 'gro rtsal 
Perhaps because of the long history between the Yölmopa incarnations and the Lords of the Northern Treasures, Tenzin Norbu was an excellent selection for the regency. Not only was he a high level student of Ngakgi Wangpo, but it was the first incarnation of Yölmopa, Śākya Zangpo, that introduced the Northern Treasures to the Ngari Brothers. In short, he had been a steward of the tradition before and could be trusted to fulfill those obligations again. Things were, however, very different this time around. To begin with, the incarnation lineages of both Ngakgi Wangpo and Tenzin Norbu had blossomed into stable, though still developing, social institutions. In addition, this time the Yölmopa Incarnation would not only pass along the reigns to the Northern Treasure Tradition, but also the stewardship of Dorjé Drak.

Another important development concerns the appointment of someone outside the family as the regent of the tradition in his absence. Ngakgi Wangpo's nephew acted as the steward of Dorjé Drak until the death of Trashi Topgyel, at which time Ngakgi Wangpo takes the reigns. The fact that neither the nephew nor any other descendent of Trashi Topgyel are named as the regent of the lineage is very significant. Yölmopa was an incarnate lama himself in a lineage that already had a storied relationship with the lords

nyid gdan sar bzhugs te phyogs bral gyi gdul bya'i re ba skong bar mdzad do//_de ltar rig 'dzin ngag gi dbang po 'di ni thub bstan rdo rje brag gi chos sde thog mar btab pa dang gdan rabs dang po yin pas lo rgyus cung zad rgyas par smos pa yin no//_ 
of the Northern Treasures, and he was selected to identify the reincarnation of Ngakgi Wangpo and enthrone him at Dorjé Drak. These events are discussed at length in the following chapter.

\section{Chapter Conclusion: The Development of an Incarnation Lineage}

It has been established above that the incarnation lineage that comes to be the primary source of authority for the Northern Treasure Tradition is not birthed in complete form but develops over time. This chapter has drawn attention to the fact that incarnate lamas, despite their ontological authority as reincarnations of imperial-era figures, must still be trained in order to receive the quintessential teachings as well as the institutional authority of their traditions. It has thus become very important to consider all of the patriarchs between the Northern Lords in order to analyze the development of the incarnation lineage in the sixteenth century. We have found that for two of these patriarchs that were recognized as adults, Lekden Dorjé and Trashi Topgyel, confirmation of their status as incarnations involved the recovery of the memories of their past lives.

The investigations of this chapter have also led us to a more critical understanding of the nature of the Northern Treasure Tradition in the sixteenth century. I have concluded that it is not entirely clear that the Northern Treasures dominated the identity of this traditional Nyingmapa lineage that connected Sākya Zangpo, Pema Wangyel, Lekden Dorjé, Trashi Topgyel, and Ngakgi Wangpo. Moreover, incarnations of several imperial-era figures act as legitimate patriarchs of the tradition rather than temporary regents, which also suggests that more than one set of treasure scriptures constituted the identity of this tradition. 
Lastly, while the system of rule by incarnation is in the end employed as a means of removing the control of Dorjé Drak from the clansmen of Trashi Topgyel, the institutions may also complement one another. Trashi Topgyel can be interpreted as having consolidated the power of the Northern Treasure Tradition in his family by identifying his own son as the next incarnation of the Northern Lords. Historically speaking, the potential for harmony is overshadowed by the fact that the system of rule by incarnation is an important factor in the transformation of the hereditary Northern Treasure Tradition into the monastic institution of Dorjé Drak. This development is discussed in more detail in the next chapter. 


\section{Chapter 4: Recognition, Enthronement \& the Web of Karmic Relationships in the Life of Pema Trinlé}

\section{Introduction}

The incarnation lineage of the Lords of the Northern Treasures develops into a robust socio-religious institution during the lifetime of Pema Trinlé (1641-1717). In this chapter, we examine several features of the institution of rule by incarnation that are adopted by this tradition for the first time. These include: the practice of empowering regents between incarnations, the formal processes of location and recognition of the incarnate lama as a child, and enthronement. In the case of the Northern Treasure Tradition, the adoption of these formal processes coincides with the final transformation of a family-based tradition into a Nyingmapa monastic tradition that is guided by the incarnation lineage of Gödem Truchen.

The second half of this chapter focuses on Pema Trinlé's web of relationships with other incarnate lamas through an examination Tenzin Norbu (1589-1644), the Fifth Dalai Lama (1617-1682), and Chöying Rangdröl (1604-1669) as they appear in The Clear White Mirror. An examination of these associations will not only deepen our understanding of Pema Trinlé, but will also shed light on the social institution of rule by incarnation in the seventeenth century.

\section{Historical Context: The Seventeenth Century}

There were many developments in the early seventeenth century that set the stage for the life and accomplishments of Pema Trinlé. When the century begins, the kingdom of Mangyül Gungtang with its royal dynasty that traces its heritage back to the early Tibetan kings persisted in the south-west region of Tibet. The influence and control of the 
Tsangpa kings, however, continued to grow throughout Central Tibet (Ü and Tsang) and the neighboring regions to the west. They conquered, for example, the area of Latö (la stod), which included Jang and the homeland of Gödem Truchen, in $1612 .{ }^{144}$ Later, the royal dynasty of Mangyül Gungtang finally meets with its demise at the hands of Tsangpa forces in $1620 .{ }^{145}$ At this moment in history, the lion's share of Tibet's political power had been consolidated in the aristocratic family of the Tsangpa dynasty.

Their dominance of the political situation was short-lived, however, as Mongol forces under the leadership of Güshri Khan (1582-1655) dispose Tsangpa rule in 1642 and transfer political authority to Lozang Gyatso (blo bzang rgya mtsho) (1617-1682), the Fifth Dalai Lama. ${ }^{146}$ Thus begins the reign of the Dalai Lamas as the secular and spiritual leaders of Central Tibet. As a result, the Dalai Lama's Gelukpa sect experienced great fortune and proliferated throughout Tibet. The rule of the Fifth Dalai Lama is also significant, for it marks an important moment in the gradual shift of political authority from powerful aristocratic families toward monastic institutions. ${ }^{147}$ This trend was to

\footnotetext{
${ }^{144}$ Bogin (2005), $x$.

${ }^{145}$ For an account of the Mangyül Gungtang dynasty, see Sørensen (2007).

${ }^{146}$ Matthew Kapstein (2006), The Tibetans (Malden, MA: Blackwell Pub., 2006), 188-
} 189.

${ }^{147}$ For a complete analysis, see: Melvyn C. Goldstein (1973), “The Circulation of Estates in Tibet: Reincarnation: Land and Politics," In Journal of Asian Studies 32, no. 3 (1973): $445-455$. 
continue for the next three centuries as landed estates were appropriated to support the propagation of monasticism.

Although the Fifth Dalai Lama was a patriarch of the Gelukpa tradition, his affiliation with the Nyingmapa is well documented. ${ }^{148}$ Thus, the period of continuous Gelukpa dominance in Central Tibet that began in 1642 and ended with its temporary disruption in 1717 was an age of great development for the Order of the Ancient. In particular, it was during this period that four of the six so-called "mother monasteries" of the Nyingmapa were established. ${ }^{149}$ One of those monasteries, Dorjé Drak, becomes the seat of the Northern Treasure Tradition and the Northern Lords.

\section{A Brief Account of the Life of Pema Trinle (1641-1717)}

The life of Pema Trinlé is nearly coterminous with this golden age of Nyingmapa development, and thus it is not surprising that his autobiography contains many details

${ }^{148}$ For a recent discussion of their relationship, see: Rindzin Dorje (rig 'dzin rdo rje) (Martin Boord). trans. (2010), A Roll of Thunder from the Void: Vajrakila texts of the Northern Treasures Tradition: Volume Two (Berlin: Wendel Verlag), xvii-xxvi.

149 For a general description of the rise of these four monasteries in the seventeenth century, see: Gene Smith (2011), 17-20. For a detailed study of Katok Monastery, which all proliferated at this time, see: Jann Ronis (2009), Celibacy, revelations, and reincarnated lamas: Contestation and synthesis in the growth of monasticism at katok monastery from the 17th through 19th centuries (Ph.D. diss., University of Virginia). 
regarding the transformation of Dorjé Drak. As a young adult, Pema Trinlé converts the estate that he inherited from his previous incarnation and his clansmen into a first-class Nyingmapa monastery that is fully capable of ordaining and training its own monks. An endowed estate (bla brang) within the monastic complex was also erected at Dorjé Drak by Pema Trinlé to be the permanent residence of the Northern Lords from one lifetime to the next.

Pema Trinlé's training begins at the age of five, but he continues to voraciously receive scriptural and ritual transmission throughout the entirety of his life. As he is vocally non-sectarian in his appreciation of Buddhist wisdom, he encyclopedically collects transmissions from all of the major schools of Tibetan Buddhism. Pema Trinlé was also a prolific author, well known for his ability to collect large quantities of tantric ritual materials and systematically arrange them. ${ }^{150}$ Many of his arrangements are still used by the Northern Treasure Tradition today. As will be discussed in greater detail below, Pema Trinlé also enjoyed a close relationship with the Fifth Dalai Lama who directly supported his training from the age of five (1646) and dispatched him all over central Tibet to perform ritual services. In this capacity, Pema Trinlé demonstrates that he is not only an accomplished scholar, but also a state-level tantric master. Pema Trinlé met with an untimely end at the hands of the Dzungars clansmen in 1717.

The details of all of these accomplishments and many more are included within the pages of the voluminous autobiography of Pema Trinlé called The Clear White

\footnotetext{
${ }^{150}$ For example of how Pema Trinlé performs such feats, see: Dalton (2002), 172-182.
} 
Mirror the begins with the regency of Tenzin Norbu and continues until 1701, when Pema Trinlé is 61 years of age, sixteen years before his death. ${ }^{151}$ Within the present context, however, the examination of this great incarnate lama will be largely limited to the first ten year of his life. ${ }^{152}$ Through an examination of these early years, we are able to observe and analyze the key events that involve his status as an incarnate lama, which is the focus of the present study.

\section{The Regent \& the Ascension of an Incarnation Lineage}

The regency of Tenzin Norbu is a significant milestone of development for the incarnation lineage of the Northern Lords. ${ }^{153}$ In the previous chapter, I demonstrated that most if not all of the individuals that maintained the Northern Treasure Tradition between the incarnations of Gödem Truchen were patriarchs in their own right; they were not temporary regents. Despite the fact that Tenzin Norbu is an incarnation of Śākya Zangpo, he is not thought of as the successor of Ngakgi Wangpo. He is not expected to reside at

151 Padma Trinlé (padma 'phrin las) (1641-1717), pad+ma 'phrin las kyi rang nyid kyi rtogs brjod rab dkar shel gyi me long. TBRC W23811 (Unpublished). This text is referred to throughout as The Clear White Mirror.

152 A translation of the first ten years of Pema Trinlé's autobiography is included in Appendix I.

${ }^{153}$ For a translation of Tenzin Norbu's autobiography and an analysis of his life, see: Bogin (2005). 
Dorjé Drak for the rest of his life managing the affairs of the estate and the religious community until his own decline forces him to pass on the leadership responsibilities to a senior student. Quite to the contrary, he is given the responsibilities of identifying the next incarnation of Ngakgi Wangpo, officially recognizing him, and enthroning the child at Dorjé Drak. Thus, the patriarchal lineage of the tradition passes for the first time from one incarnation of Nanam Dorjé Dujom to another with the help of a regent, Tenzin Norbu. The Northern Treasure Tradition of the seventeenth century, therefore, supplies us with an interesting perspective from which to consider the various stages in the development of the institution of rule by incarnation.

Tradition maintains that during his life as Śākya Zangpo, Tenzin Norbu was the patriarch of the Northern Treasure Tradition. Not only did he fulfill the leadership role at that time, he also initiated the Ngari Brothers, Pema Wangyel and Lekden Dorjé, into the cult of the Northern Treasures and groomed them to be the next stewards of the transmission lineage. With this history in mind and the apparent absence of an incarnation of Pema Wangyel, Tenzin Norbu is the obvious choice for regent to shepherd the tradition between the incarnations of Ngakgi Wangpo and Pema Trinlé. Aside from the karmic connections and the historical precedence of this relationship, however, Tenzin Norbu is also uniquely qualified for the job.

While the honor of being named regent is great, the burden of the accompanying responsibility is still greater. Within the context of a secular kingdom, a regent is charged first and foremost with maintaining the stability of the realm until a successor can reach his or her majority. The task is significantly complicated for a regent of an incarnation lineage because the identity of the successor may not be evident for several years. Moreover, the discovery of a newly born incarnate lama often requires the involvement 
of an individual with the capacity for "pure vision" (dag snang). ${ }^{154}$ While everyone, for example, dreams from time to time, the information in the dream is distorted by our mental impurities. The dreams of more highly developed individuals, on the other hand, are "pure" in the sense that the prophetic content is received in an undistorted, although still cryptic, form. As a senior student of Ngakgi Wangpo and an incarnate lama himself, Tenzin Norbu possessed the capacity for pure vision that is fundamental to the process of identifying a possible incarnate lama.

It is not surprising when all things are considered that incarnate lamas themselves are thought to be good regents or at the very least important consultants regarding the whereabouts of newly born incarnations. ${ }^{155}$ Part of the mystique of an incarnate lama is that the status suggests a mastery over the normal cyclic processes of life and death. Whether an incarnate lama is viewed as an emanation body of a Buddha or as a highlevel bodhisattva, the individual is not thought of as being bound by the same fetters of mortality as everyone else. Additionally, while all sentient beings reincarnate, an incarnate lama's level of attainment is generally thought to be elevated due to the number

${ }^{154}$ For examples, see: Tulku Thondup (2011), 62; and, Melvyn C. Goldstein (1973), “The Circulation of Estates in Tibet: Reincarnation: Land and Politics." Journal of Asian Studies 32, no. 3 (1973): 445-455.

${ }^{155}$ Tulku Thondup asserts that the majority of incarnate lamas are identified with the help of high lamas that employ their visionary expertise in the process. Most of his examples of high lamas are incarnate lamas. Tulku Thondup (2011), 62-71. 
of lifetimes he or she has already spent as a Buddhist practitioner and master. There is also a sound logic in the privileging of the visions beheld by those with strong karmic connections with the incarnate lama being sought. Perhaps because the two have met each other in many different bodies throughout the ages, it is easier to recognize one another in the new setting. Whichever perspective one adopts, incarnate lamas have a unique set of credentials that qualify them as potential regents.

The first section of The Clear White Mirror narrates the exploits of Tenzin Norbu as he attempts to identify, recognize, and enthrone the reincarnation of Ngakgi Wangpo. Instead of recounting these events from his own perspective, which would be difficult because some of them occurred while he was between incarnations and the others while he was still very young, Pema Trinlé includes a lengthy passage from an autobiography of Tenzin Norbu's that was available to him when composing his own autobiography. He also quotes from a few letters and other official documents that were written by Tenzin Norbu and are still in his possession.

In the introduction of Pema Trinlé's autobiography, he offers a detailed description of the castle of Mönkhar (mon mkhar), the surrounding lands of Namsé Ling (rnam se ling) in south-central Tibet, and his birth parents. Immediately following, he presents the excerpt from Tenzin Norbu's autobiography that involves the prophetic dream (1639) that allows the regent to discover the region where the incarnate lama will be born. The following excerpt is the first paragraph of the prophetic dream that describes an important geographical location.

I had the following dream during the first night of the eleventh month. The main part of the valley was behind me in the south and the lower part of the valley 
was [in front of me] in the north. A great river flowed to the East. There were various [clearly defined] meadows and barren swaths of land. Nestled within the rugged red rocks on the right side there was a monastery, and along the left side, where the mountain and the plains met, there was a grove of bamboo that seemed to extend far across the middle. The tributaries were like playful maidens bringing melodies as they passed. And before this yogin, the billowing image made the sound of jingling bangles. As they went winding past, [the sounds] gave me pleasure. That is how [the vision] of the land came [to me]. ${ }^{156}[\ldots]$

In The Clear White Mirror, the fact that Pema Trinlé's actual place of birth conforms to Tenzin Norbu's prophecy is proof of the Northern Lord's legitimacy. This combination of prophecy and biographical fact reflects the same logic of authentication employed in the biographies of the treasure revealers, such as The Ray of Sunlight discussed at length above. The visions, however, are not immediately understood, and there is a somewhat drawn out exchange that occurs between the master Tenzin Norbu and his senior disciple Zurchen Chöying Rangdröl. The former understands the dream from the beginning as relating to the coming reincarnation of his beloved teacher and where he will be born, but Chöying Rangdröl interprets the vision as also indicating the coming death of Yölmopa himself.

${ }^{156}$ Padma Trinlé (padma 'phrin las) (1641-1717), The Clear White Mirror, 7-8. 
The prophetic vision is an essential component of the legitimacy of Pema Trinlé as the true reincarnation of Ngakgi Wangpo. By supplying the reader with the words of the regent himself, Pema Trinlé demonstrates that he was not simply selected at random as a child. Tenzin Norbu, who himself was an incarnate lama and a companion through many lives, had a prophetic dream in which he clearly saw the region of Namsé Ling where Pema Trinlé was to be born. While the legitimacy of a treasure revealer also often involves prophecies, for them a few cryptic verses in a revealed scripture somewhere is sufficient, even if it is not discovered until long after the birth of the revealer. For Tenzin Norbu, however, he follows his own prophetic dream to locate an incarnate lama. The significance of the vision is obviously profound for Pema Trinle himself as he refers to it sporadically throughout his autobiography and often links important events, like the birth of his brother, to the details of Tenzin Norbu's vision.

\section{The Speedy Rebirth Prayer}

Another significant element of the institution of rule by incarnation that is displayed through Tenzin Norbu's regency is the "speedy rebirth prayer." These heart-felt prayers are the expression of one's desire that the teacher will not enter into final nirvana nor remain in a celestial realm, but will quickly return to human form. The appearance of this classification of literature is a natural result of the close relationship between masters and disciples in Tibetan Buddhism - students are often presented as pinning away for their beloved lamas — and the equally unique Tibetan institution of incarnate lamas. 
In the traditional accounts of the life of Sākyamuni, his death is often linked to the failings of his cousin, Ananda. ${ }^{157}$ The argument is that the historical Buddha could have continued living, if Ananda had realized that he needed to make the request. While this episode might easily be interpreted as an explanation of the Buddha's mortality, blaming it on the faults of others, the scenario offers insight into the Tibetan tradition of speedy rebirth prayer: if you do not request for your lama to continue the process of serial incarnation, he or she may not reincarnate.

The process of serial incarnation of realized or semi-realized beings is not driven by a fear of death or a desire to return to human form simply to continue living. Quite to the contrary, continued incarnation is described as occurring in response to the karmic needs of sentient beings. It is best if the needs of the master's disciples are not simply assumed, but explicitly expressed in the liturgical form of a speedy rebirth prayer and recited. It is not uncommon for such prayers to be recited routinely by religious communities that are awaiting the arrival of the reincarnation of their teachers. This tradition already existed in the seventeenth century according to The Clear White Mirror. Therein we find that Tenzin Norbu established the practice at Dorjé Drak based on the prayer that he authored.

The specific prayer that is composed by Tenzin Norbu is illuminating because it refers to Pema Trinlé's prior incarnations as Nanam Dorjé Dujom, Gödem Truchen, and Lekden Dorjé. His adoration of his recently deceased master, Ngakgi Wangpo, is

${ }^{157}$ Strong (2001), 132. 
magnified by his knowledge of his intimate involvement with the Lords of the Northern Treasures through a series of lives. He even calls upon his own powers as a reincarnation of Śākya Zangpo with the hope that this karmic connection will help fulfill his aspiration.

In the sky of the dharma-kāya, was the moon of your form body [harkening] a new day.

From then, [may time] pass quickly and [my lord] himself appear.

Like the vision of the bright light, may your entrance into the womb be unhindered, and

May the compassionate one dispel the darkness in the mind of this migratory being!

May the engendering of the son of the victorious one be well done, and Through my pure prayers, may his mother and father be blessed!

Remember your pure children for whom you have done so much. Please quickly cause the appearance of your incarnation.

Created by his family, [his body] will be a mandala with hundreds of major and minor marks.

The face of the incarnation is written in my mind, so beautiful and young. Until that time that I obtain that delightful feeling [of actually seeing you], May you be victorious over the battles and obstacles to our meeting!

Oh, Dorjé Dujom! Oh, Gödem Truchen! 
Oh, Lekden Dorjé! You are in their [incarnation] lineage!

I follow you continually in my training, studying, meditation, accomplishments, and prayers.

With your blessings, may I continue to progress without corruption!

You are the mentor with whom I have connected through innumerable births!

With these true words I pray that your compassion is quickly aroused.

By the truth of the exalted mind of the Knowledge Mantra Bearer, Sākya Zangpo, May it be just so! ${ }^{158}$

While Yölmopa does not say that these are all of the previous incarnations of Ngakgi Wangpo, it is interesting that he does not include Tropu Lotsawa. ${ }^{159}$ There are a number of possible explanations for the omission, the simplest being that Tenzin Norbu was not attempting to offer a complete list. It is entirely possible, however, that the connection does not appear in writing until the Fifth Dalai Lama's Wondrous Ocean, which delineates "all" of the previous lives of Ngakgi Wangpo. ${ }^{160}$

\footnotetext{
${ }^{158}$ This is only the second half of the prayer, the entirety of which appears in Appendix I. Padma Trinlé (padma 'phrin las) (1641-1717), The Clear White Mirror, 7-8.

${ }^{159}$ The controversial nature of Tropu Lotsawa is discussed at length in Chapter Two. ${ }^{160}$ For a complete listing, see Chapter One.
} 
In the excerpts from the Guru Trashi that were presented in the previous chapter, it was noted that Trashi Topgyel beseeched his master, Lekden Dorjé, to stave off death just before his passing. There is an interesting parallel between those events and this speedy rebirth prayer here. In both cases, they are essential to the process of reincarnation.

\section{The Family of an Incarnate Lama: Benefits \& Developments}

Padma Trinlé is born in 1641 at Mönkhar Namsé Ling to Depa Püntsok (father) and Rindzin Butri (mother). While Tenzin Norbu was doing his part to interpret the visions that were appearing to him in dreams and find the location where his master would be reborn, Pema Trinlé's mother was also receiving indications that her child was destined for greatness. ${ }^{161}$ After realizing that she was with child, she went on a pilgrimage to the Jowo statue in Lhasa to receive a prognostication regarding the destiny of her child. On the way there by boat, she experienced emotional discontentment and a desire for renunciation when her eyes caught sight of Dorjé Drak. She also reports that she could hear what sounded like the recitation of the Buddhist monastic scriptures and other prayers from within her own womb. All of these were signs of the greatness of her coming child.

Pema Trinlé's family was wealthy and active in the political as well as the religious arenas. Today, Mönkhar Namsé Ling is a large seven-story manor in Dranang

\footnotetext{
${ }^{161}$ Padma Trinlé (padma 'phrin las) (1641-1717), The Clear White Mirror, 17.
} 
(gra nang) County, which is directly south of Lhasa and the county where Mindröling is eventually established. ${ }^{162}$ This would later become the seat of the Namsé Zhamar (rnam sras zhwa mar) incarnations of the Karma Kagyupa (karma bka' brgyud pa) Order, but further research will be required in order to uncover the connections between Pema Trinlé's family and this later tradition.

It is not difficult to fathom why it was beneficial to recognize the incarnation of Ngakgi Wangpo in this powerful family. The original epicenter of the Northern Treasure Tradition was in Jang Ngamring, two large counties to the west of Zhikatsé. The new location in Gongkar (gong dkar), which is a long way to the east of Zhikatsé, is on the other side of the river and a little to the west from Mönkhar Namsé Ling. From Pema Trinlé's autobiography, it is clear that his parents were generous patrons of various high lamas from a range of different traditions. ${ }^{163}$ By naming the son of this wealthy family as the reincarnation of the incarnate lama of the Dorjé Drak monastery, the patronage of Namsé Ling is ensured.

A major development for the Northern Lords that comes to pass in the person of Pema Trinle is that he is the first incarnation to thoroughly embrace the monastic methodology. His decision to take ordination and to transform Dorjé Drak into a fully operational monastery is not surprising retrospectively as it was during the seventeenth

${ }^{162}$ Gyurme Dorje (2005), Footprint: Tibet. $3^{\text {rd }}$ Edition (Bath: Footprint), 178.

${ }^{163}$ For examples, see: Padma Trinlé (padma 'phrin las) (1641-1717), The Clear White Mirror, 39, 46, 48. 
century that the six mother monasteries of the Order of the Ancients began to flourish. Nevertheless, Pema Trinlé's autobiography does not offer much insight into what was driving this general movement within the Nyingmapa. In the case of Pema Trinlé himself, however, it is possible that his decision to remain a monk for the entirety of his life was inspired by his relationship with the Fifth Dalai Lama, who was his preceptor for every level of ordination. ${ }^{164}$

Another change for the lords of the Northern Treasures is that this is the first incarnation to be identified within a family that did not practice tantric ritualism as a hereditary trade. They were avid lay patrons, but they were not religious specialists themselves. Pema Trinlé extols his parents as non-sectarian patrons who, while maintaining a monastery on their estate, also host a large number of Nyingmapa masters as they travel back and forth through central Tibet. Whether or not it was intentional, the identification of Pema Trinlé as a child in this aristocratic family eventually displaces Trashi Topgyel's clansmen as patriarchs at Dorjé Drak. ${ }^{165}$ This subject will be discussed further below during the investigation of Pema Trinlé's enthronement.

\footnotetext{
${ }^{164}$ Pema Trinlé's relationship with the Fifth Dalai Lama is discussed in more detail later in this chapter.

${ }^{165}$ Often refer to Dorjé Drak as being in the hands of "Trashi Topgyel's clansmen" before the enthronement of Pema Trinlé. The intention is to reflect the nature of what I understand as being a classic Nyingmapa hereditary tradition before that time. Trashi
} 


\section{Approaching the Family of an Incarnate Lama}

According to The Clear White Mirror, the first indirect interaction between Tenzin Norbu and Pema Trinlé's mother, Rindzin Butri, was on the evening that Pema

Trinlé was born (1641). ${ }^{166}$ He divined that it was indeed the night of delivery even though the mother herself did not believe it would come to pass that evening. Tenzin Norbu came to Namsé Ling with an entourage and summoned a nurse. He gave her a few items that may have been intended to ease child birth as well as a small ornamental ritual dagger that Pema Trinlé would later wear hanging from a necklace as a symbol of his connection with Tenzin Norbu. That night his mother was suddenly oppressed with labor pains and a healthy male child was born. The regent celebrated the event by performing the juniper burning ceremony (lha bzangs), an event punctuated by exclamatory expressions of victory.

This reverent account of the early relations between Tenzin Norbu and the inhabitants of Namsé Ling leaves one wondering if there were any other interactions between them prior to this encounter. Did Tenzin Norbu arrive at Namsé Ling unannounced and involve himself with the intimate family business of childbirth? Were Pema Trinlé's parents aware of Tenzin Norbu and his mission to identify a child as the

Topgyel is the family patriarch that originally established Dorjé Drak and, as discussed in the previous chapter, there is evidence that his extended family resided there as well. ${ }^{166}$ Padma Trinlé (padma 'phrin las) (1641-1717), The Clear White Mirror, 17. 
reincarnation of the Lord of the new Nyingmapa monastic center thirty miles from their home? Were there third parties involved, such as the Dalai Lama or other power brokers in the region? While the precise answers to most of these questions are likely to remain unknown, it is safe to surmise that Tenzin Norbu's interest in the arriving child was no secret. Whether or not political considerations or even negotiations significantly influenced the process of identification will remain a mystery; Pema Trinlé's autobiography would have us believe that the process was guided only by visionary intuition.

\section{Informal Recognition \& Vetting the Candidate}

Soon after the child was born, a messenger was sent to Tenzin Norbu to request a name. He responds in writing (1641), blessing him with the name Karma Tsewang Püntsok (kar ma tshe dbang phun thogs) and informs the parents that there are indications that the child is a rebirth of a great person. He does not yet identify him as the reincarnation of Ngakgi Wangpo, but he does instruct the parents to take good care of the child. Tenzin Norbu then visits the newly born child and mother personally and performs a longevity blessing and other benedictions for the benefit of the pair. But, it is not until after this visit that Tenzin Norbu writes a letter to Rindzin Butri informing her that the young child is in fact the reincarnation of Ngakgi Wangpo. This information, he admonishes, is to be kept secret for several years.

With respect to Lady Rindzin,

The reason for sending [this letter] is that that son [of yours] has been prophesized by Avalokiteśvara as being the emanation of my lama. Preserve the 
connection between this boy and his cleanliness with secrecy and hiding from other people. I request that even that spike you keep in your mind. I am presenting you with cardinal details. The gift is in this basket, which [contains] a treasure of pearls. ${ }^{167}$

The above events constitute an informal recognition of an incarnate lama, but the matter is far from decided. The official recognition of Pema Trinlé will not occur until he is nearly five years of age. The delay in the process is likely a precautionary method that helps avoid the recognition of a physically or mentally limited individual as an incarnate lama. Actually, Pema Trinlé even remarks in his own autobiography that his official recognition takes places when he matured enough to make it obvious that he had no mental defects. ${ }^{168}$ Without modern medical screening methods at their disposal, the only way to test for such a condition was to allow the child time to live in the care of the birth parents until it became clear the child was suitable. At the same time, the unofficial recognition is important so that the parents are aware of the likely destiny of their child.

During the intervening years between his birth and official recognition, Pema Trinlé is permitted to live at home and develop like a normal child of his station. Tenzin Norbu does return to offer a battery of empowerments and teachings at Namsé Ling, and despite his young age, Pema Trinlé remembers the impressive figure of Tenzin Norbu

\footnotetext{
${ }^{167}$ Padma Trinlé (padma 'phrin las) (1641-1717), The Clear White Mirror, 18.

${ }^{168}$ Padma Trinlé (padma 'phrin las) (1641-1717), The Clear White Mirror, 24.
} 
with his dreadlocks and earrings from this visit. ${ }^{169}$ It is enough for Pema Trinlé to feel that he has a strong connection with Tenzin Norbu, and he later repays this kindness to the next incarnation of Yölmopa. It is evident in The Clear White Mirror that even later in life he still felt much gratitude for the master that identified him as an incarnate lama.

\section{Testing, Memory \& Official Recognition}

The formal recognition of Pema Trinlé as the reincarnation of Ngakgi Wangpo is hastened by Tenzin Norbu's decline in health when the child was but four years old (1644). ${ }^{170}$ It is interesting that the pure vision of the regent alone is not enough to settle the issue of the child's identity. Tenzin Norbu sends the materials required for the official testing procedures to Namsé Ling with other individuals who were close to Ngakgi Wangpo. At the same time, the regent began to publically and extensively declare that Pema Trinlé was in fact the reincarnation of Ngakgi Wangpo.

The tests that were administered to determine the identity of the Pema Trinle reflect the procedures that have come to be the customary form. ${ }^{171}$ As discussed in the previous chapter, the child is presented with a series of items and is expected to identify those that belonged to him or her in the previous life. Nevertheless, in the biographical accounts of testing and recognition, it is not uncommon for the children to do or say

\footnotetext{
${ }^{169}$ Padma Trinlé (padma 'phrin las) (1641-1717), The Clear White Mirror, 19.

${ }^{170}$ Padma Trinlé (padma 'phrin las) (1641-1717), The Clear White Mirror, 22.

${ }^{171}$ Goldstein (1973), 446-447.
} 
something that adds to the convictions of the proctors or the parents. ${ }^{172}$ One such performance by Pema Trinlé involved the vague recollection of an individual from his previous life upon sight. ${ }^{173}$ The child asked the man a question that revealed knowledge of a personal exchange between them during Pema Trinlé's previous life. While occurrences like these are not required, they are likely just as convincing for those involved. Tenzin Norbu's last action as regent was to send an official letter of recognition to Pema Trinlé's family along with a request for his enthronement at Dorjé Drak (1644). ${ }^{174}$ Unfortunately, he does not live long enough to see him installed as the throne holder of the newly established monastery.

${ }^{172}$ See the section entitled "The Brother-Father Regent \& the Incarnate Son: From Trashi Topgyel to Ngakgi Wangpo" in Chapter Three for an account of extraordinary ways that Ngakgi Wangpo unwittingly convinced his father of his true identity.

173 Padma Trinlé (padma 'phrin las) (1641-1717), The Clear White Mirror, 23. This section of the autobiography reveals the fact that one of Ngakgi Wangpo's nephews is among those that test the young Pema Trinlé. His presence in that party suggest that one takes caution in over-dramatizing the antagonistic relationship between Trashi Topgyel's clansmen and the development toward monasticism.

${ }^{174}$ Padma Trinlé (padma 'phrin las) (1641-1717), The Clear White Mirror, 23-24. 


\section{Enthronement, Symbolic Passage \& Departure from the Family}

This first enthronement is another noteworthy milestone that marks the maturation of the incarnation lineage of the Northern Lords. The event is transformative because it represents the official binding of the incarnation lineage to the leadership of the Dorje Drak Monastery. While Ngakgi Wangpo is traditionally referred to as the first throne holder of the monastic institution, he did not take on this responsibility until later in life when his father passed away. It is also not clear to what extent Dorjé Drak was a monastery rather than a classical Nyingmapa homestead. For Pema Trinlé, on the other hand, his identity as an incarnate lama is inextricably connected to his destiny as the abbot of Dorjé Drak. This is a responsibility that is shared by all of Pema Trinlé's future incarnations.

In contrast to the secretive process of recognition, which is largely a private affair, Pema Trinlé's departure from Namsé Ling, journey to Dorjé Drak, and enthronement were profoundly communal events. In many ways, the enthronement can be viewed as the public consummation of his status as an incarnate lama. After extensive preparations were complete, several dignitaries arrived to publically escort the young child of six to his new home in 1646 , two years after his recognition. ${ }^{175}$ Pema Trinlé mentions three of the escorts by name, and the presence of each in the entourage is significant.

The first was Rinpoche Amjak (rin po che aM ljags), who was a direct student of both Trashi Topgyel and Ngakgi Wangpo. This individual took command at Dorjé Drak

\footnotetext{
${ }^{175}$ Padma Trinlé (padma 'phrin las) (1641-1717), The Clear White Mirror, 28-29.
} 
after the passing of Tenzin Norbu, and it was now his duty to escort the young incarnate lama to his throne. We can surmise that had Tenzin Norbu survived, it would have been his honor to perform this task. As it turns out, Rinpoche Amjak is a very colorful master that has a fondness for women and alcohol, and this proclivity results in his expulsion from Dorjé Drak after the enthronement. ${ }^{176}$ Nevertheless, Pema Trinlé expresses his deep appreciation for the blessings that he received from this figure, because of all the masters that he encountered at this time, Rinpoche Amjak had the strongest connection to both Trashi Topgyel and Ngakgi Wangpo.

The second member of the escort was Rinpoche Draklha Puwa (rin po che brag lha phu ba). While there is little information available on this figure, he appears a few times in Pema Trinlé's autobiography. Rinpoche Draklha Puwa is first mentioned as one of Tenzin Norbu's confidants who offers him encouragement in the difficult process of extracting useful information about the coming incarnation from his visions. Besides accompanying Pema Trinlé in the entourage that travels together from Namsé Ling to Dorjé Drak, he also walks before the young incarnate lama swinging a censer during the actual enthronement ceremony. ${ }^{177}$

The marginally controversial figure of Lama Tropuwa (bla ma khro phu ba) is the third and final member of the escort party to be named. It is not entirely clear why he is included in these proceedings; perhaps his status as a patriarch of a well-known monastic

\footnotetext{
${ }^{176}$ Padma Trinlé (padma 'phrin las) (1641-1717), The Clear White Mirror, 27-28.

${ }^{177}$ Padma Trinlé (padma 'phrin las) (1641-1717), The Clear White Mirror, 29-30.
} 
institution alone qualified him for the honor. There aren't any significant details regarding their relationship in the autobiography, but Pema Trinlé does stop at the Tropu monastery a few times while on journeys to other locations.

These three members of the escort are significant because their presence alone expresses their consent in the passage of power at Dorjé Drak to Pema Trinlé. As the temporary throne holder of the monastery and a direct disciple of Trashi Topgyel and Ngakgi Wangpo, Rinpoche Amjak in particular is a very significant factor in the passage of authority and lineage authenticity to the young incarnate lama. In this case, one could also interpret Rinpoche Amjak's presence as proof that control of Dorjé Drak has legitimately been removed from the hands of Trashi Topgyel's clansmen and given to Pema Trinlé.

The day after the official enthronement ceremony, Pema Trinlé was offered gifts by a large procession of lamas, which was a common way to honor highly regarded individuals. ${ }^{178}$ In addition, the lay villagers arrived before his throne to bid him good tidings and present him with gifts. Later in life, Pema Trinlé is routinely involved in ritual

${ }^{178}$ Padma Trinlé (padma 'phrin las) (1641-1717), The Clear White Mirror, 29-30. To read about a Tibetan ceremony that is based on this custom, see: Hugh Edward Richardson, Ceremonies of the Lhasa Year (London: Serindia Publ., 1993), 83-84. 
activities on behalf of the villagers, particularly around the New Year. ${ }^{179}$ From the short account in the autobiography, it is evident that the festive atmosphere is akin to an oathpledging ceremony and public festival in celebration of the coronation of a king.

Upon further inspection, however, it also appears that the acquisition of an estate and lands is a key development that fostered the transformation of a decentralized religious community into a centralized religious institution with significant wealth and political influence. While it is acceptable for the leadership of the former to bounce between successors of disparate origins, it is more appropriate for the riches and political power of the emerging Dorjé Drak monastery to be passed more carefully through a single line of incarnational heirs. The preexisting cultural traditions of inheritance appear to have influenced the development of the robust forms of incarnation lineages once land, wealth, and political power were added to the equation. All of these factors led to the ascension of Nanam Dorjé Dujom's incarnation lineage as the root source of authority in the Northern Treasure Tradition.

While the ceremonial departure from his home does represent a major change in the relationship between Pema Trinlé and his family, he continues to interact with them extensively throughout his life. Particularly in the years when he is still young, his relatives take turns living with him at the monastery.

\footnotetext{
179 Padma Trinlé (padma 'phrin las) (1641-1717), The Clear White Mirror, 325-326. This passage in the autobiography also mentions the retreat that is also a part of his routine in the first month of most years.
} 
Because I was young during those [times], the monastery and Namsé Ling were like the warp and weft of the fabric [of my life]. When I stayed in the monastery, my grandfather was usually in residence [to ease my emotions]. Sometimes, my grandmother was sent as a substitute to stay with me. ${ }^{180}$

Pema Trinlé also frequently returns to his parent's estate for visits of various lengths. In his youth, the visits are intended to give the family time together, while later in life he primarily returns to perform religious services. His relationship with his family does change over the years as Pema Trinlé becomes a fully ordained monk and tantric master, but he is never forced to sever ties with them. They, in fact, appear to be life-long patrons of their special child.

Another important family relationship is maintained with his younger brother, Penchen Könchok Chödrak (pan chen dkon mchog chos grags), who was born in the year before his departure for Dorjé Drak (1645). ${ }^{181}$ His brother comes to be known as the Namsé Panchen and is renowned for his literary capacities. The siblings have a life-long master-disciple relationship and spend a considerable amount of time with one another. Later in life, they often meet either at Dorjé Drak or at Namsé Ling so that he can give his brother whatever teachings he requires. In The Clear White Mirror, Pema Trinlé

\footnotetext{
${ }^{180}$ Padma Trinlé (padma 'phrin las) (1641-1717), The Clear White Mirror, 34.

${ }^{181}$ Padma Trinlé (padma 'phrin las) (1641-1717), The Clear White Mirror, 28.
} 
asserts that he and his brother were represented as the large and small sections of the victory banner that was featured in the pure vision of Tenzin Norbu. Pema Trinlé never comes right out and says it, but what he implies is that his younger brother is a reincarnation of the Ngari Panchen Lama, who was also reincarnated as Trashi Topgyel, the father of Ngakgi Wangpo. As far as I know, his brother was never recognized as an incarnate lama, but it does appear that Pema Trinlé is intimating that the relationship between himself and his brother is parallel to the relationship between the Ngari Brothers, Lekden Dorjé and Pema Wangyel.

\section{Training the Incarnate Lama}

Pema Trinlé began his training at a very young age and continued to fervently collect empowerments for new cycles of teachings throughout his life. Even when the discussion is limited to the first ten years of his life, the volume of transmissions that he received is impressive. When one considers the number of teachings that he received in his entire life, however, it is difficult not to view Pema Trinlé as an extraordinary scholar and complete master of the accompanying ritual forms. It is easy to be impressed by Pema Trinlé's accomplishments, but it is infinitely more difficult to understand the full significance of his training and his later scholarly accomplishments. A major thread of his work appears to have been focused on the transformation of haphazard ritual systems that were maintained for generations by family lineages into first-class ritual programs fit for large-scale monasteries. If we consider his accomplishments by way of an analogy to sheet music, he collected random chord charts from folk musicians and transformed them into a score for a world-class symphony. 
As far as his status as an incarnate lord of the Northern Treasures is concerned, however, it is not surprising that he began to receive the relevant transmissions for the various cycles included in the tradition at a young age. The relevant studies began in 1645 , which was after his recognition, but before his enthronement. ${ }^{182}$ His primary link to the Northern Treasure Tradition was Chöying Rangdröl, who was a disciple of both Ngakgi Wangpo and Tenzin Norbu. Thus, the primary scriptural authority that defines the Northern Lords only passed through one individual between incarnations.

Pema Trinlé carefully presents himself as a staunch non-sectarian. In fact, the record of his tenth year in the autobiography concludes with a three-quatrain poetic declaration of the superiority of the non-sectarian perspective. He also expresses disappointment in his handlers who let their sectarian biases stop him from receiving teachings from several luminaries of the day. He particularly laments not making a connection with the third incarnation of Pema Lingpa (pad gling gsum pa gsung sprul rje tshul khrims rdo rje) (1598-1669), Kongyon Heruka (kong smyon he ru ka lha btsun nam mkha' 'jigs med) (b. 1597), and the Dradingpoché Incarnation (grwa sding po che'i sprul sku) (1617-1688). The last of these is a Drukpa Kagyupa lama, so one could imagine that Pema Trinlé's handlers might have been trying to avoid tension with the powers ruling in Lhasa. Surprisingly, his handlers even snub the Fifth Dalai Lama:

But that is not all, when [we] received the news that the Fifth Dalai Lama was going to give the Dorjé Trengwa (rdo rje phreng ba) empowerment at

${ }^{182}$ Padma Trinlé (padma 'phrin las) (1641-1717), The Clear White Mirror, 26. 
Drepung Monastery, my parents [thought] that it would be appropriate for me to [attend] because the initiation for the Dorjé Trengwa empowerment is important, the one giving the empowerment is unparalleled, and indeed lamas of all tenet systems would gather [there]. [So, they were] insistent [about] sending me. [But], Nganchang Ngakpün (sngags 'chang ngag phun) decided that there was no necessity for the Dorjé Trengwa empowerment for the [adherents] of the Order of the Ancients. My caretakers thought of the costs [of going] and upheld [the decision]. Because they were cut off [from their] good senses, I went home and until this day I have not obtained the Dorjé Trengwa empowerment. ${ }^{183}$

Once Pema Trinlé reached his majority, he stays true to his intentions and receives transmissions from every major school of Tibetan Buddhism. His passion for acquiring more and more knowledge of scriptural and ritual traditions other than his own appears to be driven in part by his desire to assimilate their strengths as he modernizes the ritual program of his own monastery. One of the results of his omnivorous appetite for education, coupled with his political access, is that his autobiography often reads as a "who's who" list of seventeenth century Tibet. A complete study of all of the transmissions that were received by Pema Trinlé is beyond the scope of this study, but it would surely allow us to more fully appreciate his colossal achievements.

\footnotetext{
${ }^{183}$ Padma Trinlé (padma 'phrin las) (1641-1717), The Clear White Mirror, 51.
} 


\section{Karmic Relationships}

The proliferation of incarnation lineages in the sixteenth and seventeenth centuries led to the creation of an elite class of religious patriarchs. The resulting web of karmic relationships acted metaphorically as an adhesive that helped hold the system together and allowed it to grow. By lending their authority to the recognition of other incarnate lamas, they ensure the continuation of their own lineage as well. The remainder of this chapter is dedicated to the description and analysis of three of Pema Trinlés most important multi-life relationships that were reestablished in his youth. Each profile further illuminates elements of the institution of rule by incarnation in the seventeenth century.

\section{Yölmopa Tenzin Norbu}

As discussed in detail above, Tenzin Norbu (1589-1644) performed the essential duties of the regency that ensured the enthronement of the reincarnation of Ngakgi Wangpo at Dorjé Drak. ${ }^{184}$ The interpretations of his visions are what led to the identification and recognition of Pema Trinlé as the next incarnation of the Northern Lords and ensured the authentic transmission of the tradition from one generation to the next. Tenzin Norbu's involvement in the process grew out of his close relationship with Ngakgi Wangpo who not only transmitted the Northern Treasures to him, but also

\footnotetext{
${ }^{184}$ As stated above, for a translation of Tenzin Norbu's autobiography and an analysis of his life, see: Bogin (2005).
} 
encouraged him to give up his monastic vows and embrace the lifestyle of a Nyingmapa tantric specialist. ${ }^{185}$ It is not uncommon for the closest disciples of a deceased master to be involved in the location and identification of his reincarnation. Because Tenzin Norbu passed away while Pema Trinlé was so young, however, he was not able to transmit the Northern Treasures directly to the young incarnate lama; this responsibility would be assumed by another disciple of Ngakgi Wangpo. Nevertheless, Tenzin Norbu had performed this essential duty in the past in the form of Sākya Zangpo. He then passed the Northern Treasures to Lekden Dorjé. The paths of the two incarnation lineages are entangled, however, as far back as the eighth century when both were embodied as ministers of King Trisong Detsen and disciples of Guru Rinpoche.

There are additional encounters between these two incarnation lineages recorded within the pages of The Clear White Mirror. Unfortunately, Pema Trinlé is only six years of age when Tenzin Norbu reincarnates in 1647 . This is coincidently the same year that Pema Trinlé is enthroned at Dorjé Drak. Twelve years pass before they are finally able to meet face to face in Nakartsé (sna dkar rtse) in $1659 .{ }^{186}$ The highlight of their meeting is

${ }^{185}$ Bogin (2005), 51-57.

${ }^{186}$ Padma Trinlé (padma 'phrin las) (1641-1717), The Clear White Mirror, 123. Note that Pema Trinlé was too young to aid in the identification of Tenzin Norbu's reincarnation. These circumstances involving the relationship between only two incarnation lineages demonstrates why more lineages must be included if there is always going to be an incarnate lama that is mature enough and willing to aid in the process of recognition. 
the naming ceremony. Pema Trinlé points out that it is hardly necessary considering the fact that this fourth incarnation of Yölmopa has already received the name Zilnön Wangyel Dorjé (zil gnon dbang rgyal rdo rje) from the Fifth Dalai Lama and the name Nganchang Tutop (sngags 'chang mthu stobs) from the Sakyapa. Nevertheless, Pema Trinlé obliges the request by giving him the lengthy name Rindzin Pema Tekchok Tenpé Gyeltsen Jikdrel Tutop Wangchuk (rig 'dzin pad+ma theg mchog bstan pa'i rgyal mtshan 'jigs bral mthu stobs dbang phyug). Pema Trinlé mentions beforehand that it would have accorded with Tenzin Norbu's aspirations for his reincarnation to be trained at Dorjé Drak, but there is no evidence that this happens.

Other pairs of incarnation lineages, however, have developed that from their very conception are intended to work together in order to maintain institutional continuity and scriptural authenticity. ${ }^{187}$ The incarnations of Dzogchen Rinpoche and Dzogchen Ponlop Rinpoche, for example, have worked together since the establishment of the Dzogchen Monastery in the seventeenth century in order to maintain the abbacy of the institution as well as the purity and potency of the Dzogchen Khandro Nyingtik teachings. They are also routinely involved in the recognition of each other's reincarnations after one of them

187 As an example of how multiple incarnation lineages work together to maintain institutional continuity, see Goldstein's discussion of the Dalai Lamas and the five regent lineages. He points out that more than two incarnation lineages are required to guarantee that there will always be an adult regent available when needed. Goldstein (1973), 447448. 
passes. Analyzed from the perspective of the routinization of charisma, this is in fact a very strong method for maintaining the defining authority of the tradition. The Northern Treasure Tradition itself eventually includes several different incarnation lineages; the Taklung Tsetrul Rinpoche is currently the most senior lineage holder of the Northern Treasure Tradition and abbot of the Dorjé Drak Monastery that has been recreated in India. Further research is required in order to shed light upon how the relationship between the two incarnations worked together in order to maintain the authority of their traditions throughout the centuries.

\section{The Great Fifth Dalai Lama}

There is a tendency to examine historical figures such as the Lozang Gyatso (blo bzang rgya mtsho) (1617-1682), the Fifth Dalai Lama, from a purely political perspective. This somewhat skeptical, though not entirely unwarranted, interpretive platform leads one to understand the Fifth Dalai Lama's stewardship of Pema Trinlé and support of the Dorjé Drak Monastery as an attempt to expand his own Gelukpa-based religious and political authority to include Nyingmapa sources as well. Another of the natural conclusions of this line of reasoning is that there was a lack of sincerity in the relations between the Fifth Dalai Lama and Pema Trinlé and that the former viewed the latter as a political pawn rather than a beloved disciple and ally. 
Conversely, there is much evidence in The Clear White Mirror to support the notion that relations between the two parties were sincere. ${ }^{188}$ The Fifth Dalai Lama's general proclivity toward things Nyingmapa was likely due in part to the religious affiliations of his parents, who allowed Ngakgi Wangpo to bless their child in the year of his birth (1617). The relationship with the Northern Treasures that began when he was a child continued throughout his life. Although his root teacher for the Northern Treasure Tradition was Zurchen Chöying Rangdröl, the Fifth Dalai Lama received empowerments directly from Lekden Dorjé, Trashi Topgyel, and Ngakgi Wangpo in visions later in

${ }^{188}$ For an English translation of the Fifth Dalai Lama's hagiographic details, see: Zahiruddin Ahmad, Tr., Sanis-rGyas rGya-mTSHo: Life of the Fifth Dalai Lama Volume IV, Part I. New Delhi: International Academy of Indian Culture and Aditya Prakashan, 1999). Other important sources for the Dalai Lamas are: Martin Brauen, ed. (2005), The Dalai Lamas: A Visual History (Chicago, Serindia Pub.), Aris, Michael Aris (1989), Hidden Treasures and Secret Lives (London and New York: Kegan Paul International); Kurtis R. Schaeffer (2006), "Ritual, Festival and Authority under the Fifth Dalai Lama." In Power, Politics, and the Reinvention of Tradition: Tibet in the Seventeenth and Eighteenth Century Tibet: Proceedings of the International Association for Tibetan Studies, Xth Seminar, Oxford University, 2003. Kurtis R. Schaeffer and Bryan J. Cuevas, Editors. (Leiden: Brill Pub.), 187-202. 
life. ${ }^{189}$ There are also countless details throughout The Clear White Mirror in which he expresses his devotion to the Fifth Dalai Lama as the "supreme lord" (rgyal dbang mchog). ${ }^{190}$

The relationship between the Fifth Dalai Lama and Pema Trinlé begins soon after the latter's installment as the throne-holder of the Dorjé Drak Monastery (1646). ${ }^{191}$ Even though he is still in his minority and largely controlled by his handlers, the enthronement transformed Pema Trinlé from a potential to an actual broker of religious and political authority in central Tibet. As the top political figure of the time period and an ardent practitioner of the Northern Treasures, it is not surprising that the Fifth Dalai Lama wanted to have this meeting so soon after the enthronement. It should be noted that there are no indications in the autobiography that the Dalai Lama was involved in the recognition of Pema Trinlé as the reincarnation of Ngakgi Wangpo. Notwithstanding the lack of evidence, it is difficult to imagine that there weren't any relations between Namsé Ling and the political powers in Lhasa.

189 Zahiruddin Ahmad, Tr., Sanis-rGyas rGya-mTSHo: Life of the Fifth Dalai Lama Volume IV, Part I. New Delhi: International Academy of Indian Culture and Aditya Prakashan, 1999), 174.

${ }^{190}$ Padma Trinlé (padma 'phrin las) (1641-1717), The Clear White Mirror, 33, 46.

${ }^{191}$ Padma Trinlé (padma 'phrin las) (1641-1717), The Clear White Mirror, 30-31. 
As Pema Trinlé approaches Drepung to meet the Dalai Lama for the first time (1646), he is greeted on horseback by the current regent, Sönam Chöpel (1595-1657). ${ }^{192}$ This begins a series of relationships between Pema Trinlé and the various regents of the Fifth Dalai Lama. It should be point out that the duties of the regents of the central government were much more akin to those of a chief minister or "hand" that is active while the legitimate sovereign is in his or her majority. Nevertheless, the Dalai Lama's fifth regent, Sangyé Gyatso (1653-1705), with whom Pema Trinlé is to become closely acquainted, does notoriously facilitate the transition between the Fifth and Sixth Dalai Lamas.

The tonsure ceremony with the Fifth Dalai Lama is Pema Trinlé's first symbolic step on the path of ordination. The offering of the crown of one's head in the ceremony generally symbolizes one's renunciation of secular concerns and acceptance of the Buddha, the Buddhist teachings, and the Buddhist community as one's sole refuges. Additionally, the exchange with the Dalai Lama includes a naming ceremony. Although he had already received a name from Tenzin Norbu, his request from the Karmapa was denied. ${ }^{193}$ It is the name that he receives from the Fifth Dalai Lama, however, that comes to define him: Lozang Pema Trinlé Tekchok Wang-gi Gyelpo Yong Düdé (blo bzang pad+ma 'phrin las theg mchog dbang gi rgyal po yongs 'du'i sde).

\footnotetext{
192 Padma Trinlé (padma 'phrin las) (1641-1717), The Clear White Mirror, 30-32.

${ }^{193}$ Padma Trinlé (padma 'phrin las) (1641-1717), The Clear White Mirror, 18-19.
} 
The relationship between the two incarnate lamas appears to be founded on the principles of monasticism as the Dalai Lama is also Pema Trinlé's preceptor for his novice vows at age twelve (1652) and his full ordination at age nineteen (1659). ${ }^{194}$ As discussed above, Pema Trinlé is significantly the first incarnation of the lineage to adopt the monastic lifestyle and it is not entirely clear, therefore, in what way the estate of Dorjé Drak was "monastic" before his stewardship.

After the tonsure and naming ceremonies, Pema Trinlé was invited to attend the practice session that followed before returning to Dorjé Drak. It is at this time that he receives his first instructions from the Dalai Lama in the form of an introduction to the seven-line prayer of Guru Rinpoche. ${ }^{195}$ At some point after Pema Trinlé and his entourage return home, his tutors begin to make requests to receive important empowerments for the Northern Treasure Tradition from the Fifth Dalai Lama. He dispatches a preceptor from his own court to Dorjé Drak as a long term tutor for Pema Trinlé. In the meantime, he uses a strategy that he employs several times throughout his reign in order to satisfy the demands of many disciples at once, the large-scale empowerment ceremony. Instead of granting the same overlapping set of empowerments over and over again at different times to different people, he invites everyone who he

194 Padma Trinlé (padma 'phrin las) (1641-1717), The Clear White Mirror, 69-70; 123124.

${ }^{195}$ Padma Trinlé (padma 'phrin las) (1641-1717), The Clear White Mirror, 32-33. 
wishes to receive the transmission to his monastic seat for a large-scale empowerment ceremony.

In the year 1649, the Dalai Lama invited a group of about seventy lamas for an empowerment ceremony in commemoration of Trashi Topgyel at the Potala. While there were other monastic heads in attendance at the event along with their own entourages, the proceedings of the event were likely arranged for the benefit of the nine-year-old Pema Trinlé:

On the twenty first day of the second month, [we] commemorated [the life of] Trashi Topgyel at the Potala, that second harbor [of Avalokiteśvara], in the presence of the Fifth Dalai Lama. In the past, [we] prayed [to the Supreme King of the Victors] expressing how [we] needed a great number of teachings from our own Nyingmapa tradition, [and he chose this day to fulfill our prayers]. Zhapdrung Rinpoche (zhabs drung rin po che) from Nenying (gnas snying), [several other] venerable [lamas] together with the essential monks of [their] monastic communities, and I [were all there, totaling] about seventy people [in all that were] there to receive teachings.

[We] obtained the great empowerment of the Awareness-Holder (rig 'dzin gdung sgrub) of the Northern Treasure Tradition, using the painted cloth mandala in the "Three Realms" chamber and the extensive empowerment of the heart practice of the Wrathful Body (drag po rtsal) and the related Eight Great Practices (sgrub sde brgyad). We entered into the definitive bliss of a version of the Mañjuśrī Yamāntaka that was a union of the revealed Gyazhang (rgya zhang) version, which was a resplendent flower like the seal of samsara and nirvana, and the stream of empowerments that came through the Nub (gnubs) clan. We also 
received an extensive transmission of the verbal preliminary teachings (kha bka' ba'i slob ma sta gon) and the empowerments for the Complete Liberation of the Three Realms (khams gsum yongs sgrol), the weapon's rites (zor), stūpa rites (mchod rten), and tantric master rites (rdo rje slob dpon) in accordance with the traditional method of Trashi Topgyel.

During the weapon's empowerment, [he] performed [with] great kindness and very elaborately; he even wore special clothing and things like that. Because I was [still] young at that time, I did not [yet] possess such things as the [weapons and clothing that are donned by students], and thus Nenying Zhapdrung (gnas snying zhabs drung) assisted [me] during the weapon's empowerment.

Other than that, [the Supreme Lord] even kindly issued the thoroughly complete empowerment and reading transmission for the Prayer that Fulfills all Aspirations Treasure Cycle (bsam pa lhun grub ma'i sgrub skor gu ru yon tan gter mdzod) from the Profound Treasure of the Awareness-Holder (zab gter rig 'dzin yongs 'dus) of the Ngari Panchen (mnga' ris paN chen) [i.e., Pema Wangyel] and the long-life empowerment of the Immortal Vaiśravaṇa ('chi med dpal ster). Six [other] masters and I obtained with delightful friendliness the initiation of the Profound Treasure of Vishnu's Razor (khyab 'jug dug gi spu gri), a closed teaching of great profundity, to form a karmic connection [between us]. The Supreme King of the Victors even kindly issued to us individually the extensive lay vows (yongs rdzogs dge bsnyen), and in the end we [all received] auspicious 
gifts of various types. As we had become rich with the glory of both religion and [worldly] wealth, we all returned to our own abodes. ${ }^{196}$

Pema Trinlé participates in several of these large-scale empowerment ceremonies in his life. In this first experience, he was only a recipient of the featured transmissions, but over time he also participates as a master as well. This form of mass initiation likely predates the Fifth Dalai Lama, but as the head of growing monastic empire with unlimited resources it is equally likely that he is responsibility for the flowering of the ritual form. This particular ceremony is noteworthy for the Northern Lords because it demonstrates the Fifth Dalai Lama's reverence and support of the tradition.

Another noteworthy way in which the Fifth Dalai Lama benefited the Northern Lords is through his authorship of the biography of Ngakgi Wangpo, The Wondrous Ocean, which has been discussed above. The text has already been identified as an important contribution to our understanding of the incarnation lineages of the seventeenth century because it is not simply a biography of one of Ngakgi Wangpo's lives, but all of them since his emergence from the primordial buddha. Not only does the work solidify the authority of the Northern Lords as a genuine incarnation lineage, it also illuminates the Fifth Dalai Lama's understanding of incarnation lineages and the legitimization strategies with which they are invested.

${ }^{196}$ Padma Trinlé (padma 'phrin las) (1641-1717), The Clear White Mirror, 39-40. 
In many ways, it is the three-year retreat in his early twenties (1660-1662) that marks Pema Trinlé's passage from a childhood to adulthood. Shortly after this event, the Fifth Dalai Lama and his regent begin to dispatch Pema Trinlé all over central Tibet to perform ritual services on their behalf. ${ }^{197}$ Some of the responsibilities that he receives from the Fifth Dalai Lama are routine matters regarding the welfare of Tibet, such as the ritual ceremonies at Samyé. ${ }^{198}$ For many years Pema Trinlé makes regular visits to this important temple complex in order to renew the consecration of the site. One of the consequences of performing all of these services at Samyé and elsewhere is that he receives the patronage that could have gone directly to Lhasa. ${ }^{199}$

Pema Trinlé is the master of ceremonies for several high-profile events that are conducted on behalf of the Fifth Dalai Lama. Perhaps the most controversial of which features the wrathful destruction of a certain gnome-spirit (dam srid). ${ }^{200}$ This event places

\footnotetext{
${ }^{197}$ Padma Trinlé (padma 'phrin las) (1641-1717), The Clear White Mirror, 180-181.

${ }^{198}$ Padma Trinlé (padma 'phrin las) (1641-1717), The Clear White Mirror, 164-165.

${ }^{199}$ Padma Trinlé (padma 'phrin las) (1641-1717), The Clear White Mirror, 290-291.

${ }^{200}$ There are those who claim that Pema Trinlé's exorcism was clearly ineffectual since the affair was hardly settled after his performance in the $17^{\text {th }}$ century. Without intending to take sides in the matter in any way, I would like to point out that exorcisms of the sort are quite often performed on a regular basis. Even though a ritual practice may claim to banish, burn, bite, or otherwise destroy a particular entity (usually more than one method
} 
Pema Trinlé at the heart of what is today commonly referred to as the "Shugden Affair." ${ }^{201}$ I do not wish to make a study of this controversial issue here, and so I will leave the details of the situation to be explained elsewhere. What is significant within the present context is that the Fifth Dalai Lama, perhaps the individual with the greatest resources, selects the 35 year-old Pema Trinlé and master of the Northern Treasure Tradition to perform this important exorcism (1675). ${ }^{202}$ His selection for this task speaks volumes about the Fifth Dalai Lama's high regard for this incarnate lama and his tradition.

Another sign of their closeness is that Pema Trinlé was among those who knew that the Fifth Dalai Lama had died in 1682. Some accounts mention that Pema Trinlé had a premonition that the Supreme Lords was about to die and informed the regent Sangyé Gyatso (1653-1705) about this eleven days prior to his actual passing. ${ }^{203}$ The order of events is somewhat shrouded in Pema Trinlé's autobiography because from 1682 until

is used in a single practice), it is still quite possible that the same ritual will need to be performed the following year.

${ }^{201}$ For more on this subject, see: Georges Dreyfus (1998), “The Shud-den Affair: History and Nature of a Quarrel." Journal of the International Association of Buddhist Studies 21. no. 2 (1998): 227-270.

${ }^{202}$ Padma Trinlé (padma 'phrin las) (1641-1717), The Clear White Mirror, 307-308. ${ }^{203}$ Rindzin Dorje (rig 'dzin rdo rje) (Martin Boord) (2010), xxvi. 
1696 he authors his running record of his life as if the Dalai Lama were still alive. Several times he expresses heartfelt longing for his master, but he never comes right out and says that he knows the Fifth Dalai Lama has died. When his narrative reaches 1697 , roughly about the time when Sangyé Gyatso reveals the news about the Dalai Lama, Pema Trinlé abruptly deems "part one" of the autobiography complete. He then begins the second installment of his autobiography back around the year 1682, when the Fifth Dalai Lama actually passed away. At this point, he illuminates many of the details of his life in those intervening fifteen years that he clearly felt he could not mention without revealing the secret of his master's demise. It is only after 15 folios (or 30 sides) that he completes his recap of the missing events of these days and continues with his autobiography in the year 1698 .

One must wonder what would have happened if Pema Trinlé died before the regent allowed for the Dalai Lama's death to be known publically. Would his autobiography have portrayed him as someone who did not know about it? Had he been recording his covert operations in a secret autobiography that he merged with the exoteric version once it was safe? Either way, Pema Trinlé's dedication to the Dalai Lama incarnation lineage is intimately ingrained into the very structure of his autobiography. 


\section{Structure of Pema Trinlé's Autobiography, The White Crystal Mirror}

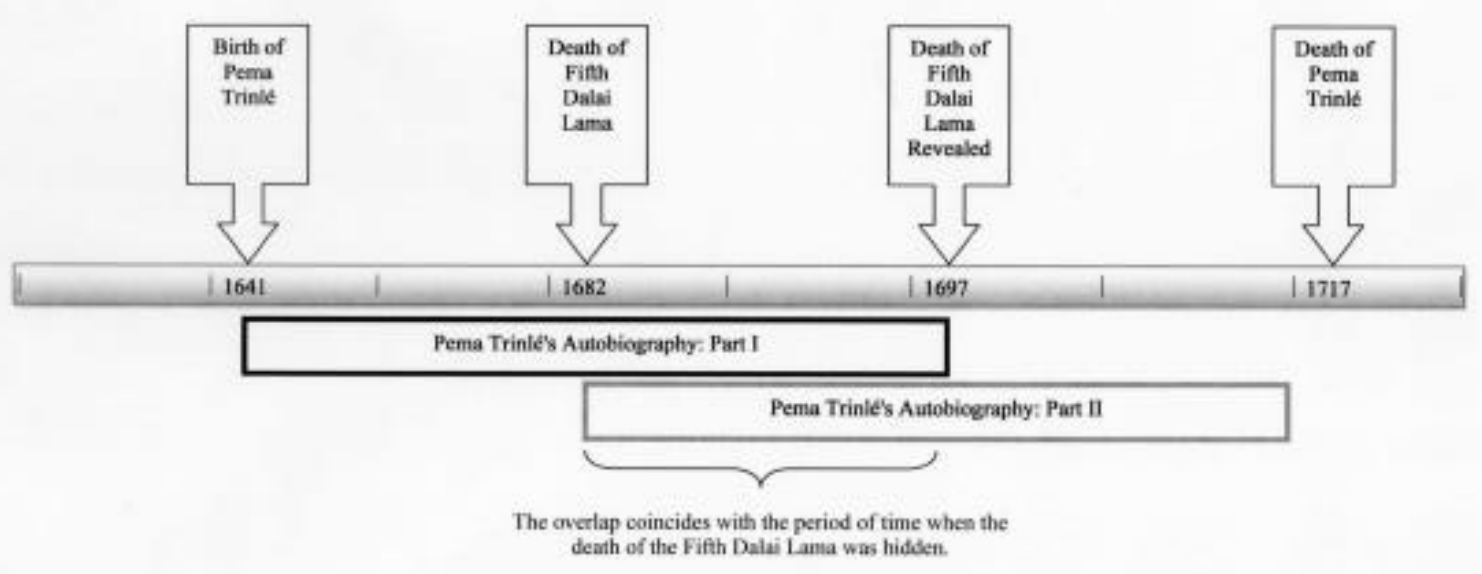

One of Pema Trinlé's more widely known accomplishments of the secret fifteen years is that he was intimately involved with the consecration of the various components of the Potala that were associated with the Fifth Dalai Lama and his remains. ${ }^{204} \mathrm{He}$ also is known to have commissioned some of the latter construction of the palace in the Dalai

204 Tupten Gyeltsen (thub bstan rgyal mtshan) (1992), "Abridged Biography of the Author [Padma Trinlé]" (mdzad pa po'i lo rgyus mdor bsdus). in The [Potala] Catalog of the Collected Works of Nyingma Authors (rnying ma'i gsung 'bum dkar chag). (Lhasa: S.N.), 271-273. 
Lama's absence. ${ }^{205}$ Most significant for the present study, however, was Pema Trinlé's involvement with the Sixth Dalai Lama. ${ }^{206}$ Pema Trinlé and Terdak Lingpa (1646 - 1714) from Mindröling were dispatched as a team to Nakartsé by Sangyé Gyatso to take part in the official recognition of the Sixth Dalai Lama (1697). They perform many blessings for the child and give their consent in the recognition process. Pema Trinlé has several visions involving the Sixth Dalai Lama and reports frequently on his growing devotion to the reincarnation of his preceptor.

\section{Zurchen Chöying Rangdröl}

The third and final incarnate lama to be discussed is Zurchen Chöying Rangdröl (zur chen chos dbyings rang grol) (1604-1669). His title signifies that he is a scion of the prestigious Zur clan that received transmission of a series of tantric cycles in the eleventh century and maintained them in a family practice lineage. Six hundred years later, these teachings were inherited by Chöying Rangdröl. Pema Trinlé's autobiography allows us to examine this representative of the Zur family at a crucial moment in the rise of succession by incarnate lamas.

Although a disciple from the age of nine (1613), Chöying Rangdröl is among those close students that Ngakgi Wangpo gathers with him at Dorjé Drak after his father,

205 Tupten Gyeltsen (thub bstan rgyal mtshan) (1992), "Abridged Biography of the Author [Padma Trinlé]," 271-273.

${ }^{206}$ Padma Trinlé (padma 'phrin las) (1641-1717), The Clear White Mirror, 1016-1017. 
Trashi Topgyel, passes away and he takes command of the family estate. After the passing of Ngakgi Wangpo, Tenzin Norbu becomes his main teacher and we find evidence of their relationship in the various episodes involving the interpretation of the visions that eventually lead to the discovery of Pema Trinlé. Around this same time period, Chöying Rangdröl transmits the Northern Treasures that he received from Ngakgi Wangpo and Tenzin Norbu to his own illustrious student, the Fifth Dalai Lama. It is not until after Pema Trinlé is officially recognized, enthroned at Dorjé Drak, and tonsured by the Fifth Dalai Lama that Chöying Rangdröl establishes relations with the young incarnate lama and begins to transmit the Northern Treasures to him (1648).

Chöying Rangdröl is obviously an important connection for Pema Trinlé because he is a direct link to the Northern Treasure transmissions that define Pema Trinlé's incarnation lineage. Their relationship, however, was not merely of a practical manner. The pair met frequently during those early years in various locations, including Pema Trinlé's seat at Dorjé Drak, his parents' estate at Namsé Ling, or Chöying Rangdröl's seat at Gungtang. ${ }^{207}$ While the tonsure ceremony with the Fifth Dalai Lama was Pema Trinlé's first symbolic step on the path of renunciation, it is through his intimate relationship with Chöying Rangdröl that he takes the first actual step on that path.

\footnotetext{
207 This is a monastic institution south of Lhasa in Central Tibet, not to be confused with Mangyül Gungtang.
} 
In the year of the Earth-Mouse (1648), when I was eight years of age, the great Zurchen Chöying Rangdröl came from Gungtang to our monastery, and we requested a few empowerments and blessings. In particular, [Chöying Rangdröl] said to me, "I will now open the door of our initial religious connection." He then gave me the ritual and liturgical instructions for the longevity benediction of the Iron-Tree cycle, and I received them [myself]. Then, he gave me drawings for the emanation body of Iron-Tree and the enjoyment body of Amitāyus (tshe dpag med) and [told me] to think of them as connected [to each other].

One day when the stars were aligned, all the necessary preparations were made in the shrine room of Dorjé Drak. As soon as I had completed the empowerment practice there, I performed the preliminary practices such as the bestowment of the donations for the initiation gift and physical blessing [to be given by] the lord lama. Then, he bestowed the empowerment for the Iron-Tree cycle on a few older monk and my parents who came from Namsé Ling. After that, I performed the reading transmission of The Seven-Line Prayer along with the entire monastic assembly. That was the beginning of the journey [through] the deception of this life. ${ }^{208}$

Chöying Rangdröl was Pema Trinlé's first significant teacher in that their connection was not maintained primarily for the purpose of transmitting empowerments,

${ }^{208}$ Padma Trinlé (padma 'phrin las), The Clear White Mirror(1641-1717), 35-36. 
but involved a close relationship over a long period of time that allowed them to grow closer together. One of the episodes that binds them was the death of Pema Trinlé's grandmother (1648). ${ }^{209}$ They are together when the news reaches the young lama, and Chöying Rangdröl is commissioned to perform the funerary rites. As his disciple, Pema Trinlé plays an active role in these proceedings and even acts as the master of ceremonies for the concluding event of the ritual sequence. There is also a series of statues that are constructed in relationship to the funerary rites, and Chöying Rangdröl consecrates them when they are installed at the newly renovated Dorjé Drak monastery. Over the years, Chöying Rangdröl imparts a wealth of transmissions to Pema Trinlé and takes an active part in his training by allowing him to act as a ritual attendant on several occasions.

When Chöying Rangdröl passes away in 1669, however, their intimate relationship was far from over. Pema Trinlé is invited to come recognize his next incarnation at the Potala in $1679 .^{210} \mathrm{He}$ is, of course, simply returning the favor as Chöying Rangdröl was intimately involved with the recognition of Pema Trinlé. ${ }^{211}$ It should be noted that Chöying Rangdröl himself was a recognized incarnation of Drungpa

\footnotetext{
${ }^{209}$ Padma Trinlé (padma 'phrin las), The Clear White Mirror(1641-1717), 36-37.

${ }^{210}$ Padma Trinlé (padma 'phrin las), The Clear White Mirror(1641-1717), 343.

${ }^{211}$ The view expressed in The Nyingma is that Chöying Rangdröl was a primary agent is the recognition, enthronement, and training of Pema Trinlé. Dudjom Rinpoche ('Jigs-bra1 ye-shes rdo-rje), The Nyingma School of Tibetan Buddhism. Trans. Rdor-rje 'Gyur-med and Matthew Kapstein (Boston: Wisdom Publications, 1991), 683.
} 
Könchok Rinchen (drung pa dkon mchog rin chen), and his father was an incarnation of Kumārādza (1266-1343), who was an important lineage holder of the Great Perfection. ${ }^{212}$ Thus, the Zur patriarchs, who possessed status and authority because of their clan's long history with the kama traditions, were already employing serial incarnation. At least through Chöying Rangdröl, however, succession was still hereditary, and serial incarnation, therefore, strengthened rather than weakend their clan power. It would be interesting to know whether or not his reincarnation was selected from the Zur clan, but there is no record of this in The Clear White Mirror and there is an apparent lack of biographical material available on this figure.

In 1684, the Chöying Rangdröl incarnation, Ngakwang Künga Sönam (ngag dbang kun dga' bsod nams), arrives at Dorjé Drak for tonsure and to begin training under the tutelage of Pema Trinlé. ${ }^{213}$ Their relationship blossoms quickly and two years later Pema Trinlé is already referring to Ngakwang Künga Sönam as his chief disciple. ${ }^{214}$ By the year 1688, the two have begun to work together as master of ceremonies and ritual assistant. In 1690, when Pema Trinlé is nearly fifty years of age, he steps down as the active abbot and places his treasurer is charge of the day-to-day affairs of Dorjé Drak. After nearly 45 years of toil for the benefit of his monastery and students, he leaves central Tibet on a pilgrimage to Jang Ngamring, the original epicenter of the Northern

\footnotetext{
212 The Nyingma (1991), 679.

${ }^{213}$ Padma Trinlé (padma 'phrin las), The Clear White Mirror(1641-1717), 408-409.

${ }^{214}$ Padma Trinlé (padma 'phrin las), The Clear White Mirror(1641-1717), 421.
} 
Treasure Tradition. The record of his exploits during this year-long journey fills nearly 100 folios (200 sides) of the autobiography. ${ }^{215}$ While his treasurer is in charge of the monastery in his absence, it is Ngakwang Künga Sönam that is called upon from this time forward for any high-profile appearances that cannot be attended by Pema Trinlé himself.

The later years of Pema Trinlé's autobiography are, in fact, peppered with accounts of the activities performed by Ngakwang Künga Sönam. Even after his return to Dorjé Drak as abbot emeritus, he tends to dispatch the young incarnate lama more and more as he increases in age. A highpoint of his career occurred in 1699 when he was commissioned to be the master of ceremonies for a large-scale ritual performance including one hundred monks that was intended to stave off military attacks. ${ }^{216}$ Although many of the details of Ngakwang Künga Sönam's life can be gleamed through The Clear White Mirror, a biography of his own has not yet surfaced.

\section{Chapter Conclusion: The Robust Incarnation Lineage}

In this chapter, we have witnessed the maturation of the incarnation lineage of the Lords of the Northern Treasure Tradition. The staggering differences between the sixteenth and seventeenth century versions of the tradition are enough to make anyone skeptical about the continuity of the incarnation lineage throughout those centuries. The skepticism is not warranted, however, because we can now more fully appreciate that the

\footnotetext{
${ }^{215}$ Padma Trinlé (padma 'phrin las), The Clear White Mirror(1641-1717), 491-687.

${ }^{216}$ Padma Trinlé (padma 'phrin las), The Clear White Mirror(1641-1717), 1103-1104.
} 
social institution of rule by incarnation was slowly adopted over several generations Moreover, it would be a mistake to employ the standards of the robust form in order to judge the authenticity of the developing forms.

The existence of a regent as a temporary steward has proven to be of great importance in this evolution. Whether a single person acts as a regent or a group of people ensure that the duties of a regent are performed, it is essential to have a powerful agent to oversee the identification, recognition, and enthronement of the new incarnate lama. A regent is also very important due to the temporary nature of the individual's position of leadership. Because the regent is not instated as a successor and rules only in the absence or minority of the true sovereign, it is less likely that the tradition will revert back to other forms of succession. ${ }^{217}$

There is also a stark contrast between Pema Trinlé and his predecessors when family relationships are concerned. On the one hand, because the main source of information for Pema Trinlé employed above is his extensive autobiography, we are able to fully appreciate the extent of his family relationships that persisted throughout his life despite that fact that he was an incarnate lama and a fully ordained monk. On the other hand, it is also very significant that Pema Trinlé's parents are the first of the incarnation lineage to not be religious specialists themselves; they are important because of their secular power in central Tibet rather than their religious heritage.

217 Goldstein observes that in the case of the Dalai Lamas, regents have often had extended reigns and used the position for personal gain. See: Goldstein (1973), 450-455. 
Additionally, Pema Trinle is the first of the incarnations to go through the processes of identification (i.e., informal recognition), formal recognition, enthronement, and training in the manner that becomes normative for incarnation traditions in future generations. The recognition of his predecessor, Ngakgi Wangpo, is an example of an alternative version of identification and recognition because he was identified by his own father. Moreover, it does not appear that Ngakgi Wangpo takes control of the estate at Dorjé Drak until after the passing of his father. Both of these facts are indications that the incarnation lineage was still in the developmental stage as it still demonstrated many aspects of the traditional inheritance system of the Order of the Ancients.

Retrospectively, it is not surprising that the greatest continuity with the tradition of his forbearers is the importance of karmic relationships that persist from one life to the next. The web of interrelations between various incarnation lineages begins to flower for the Northern Treasure Tradition in the sixteenth century. As a Nyingmapa treasure tradition, the links to the eighth century figures of King Trisong Detsen and Guru Rinpoche are of paramount importance, and these connections are obviously maintained through narratives that include successive incarnation. The legendary nature of these past relationships underscores the importance of biography and autobiography in the authority structure of the system. In the seventeenth century, Pema Trinlé finds himself at center stage strengthening old relationships and forging new ones with some of the most powerful figures in Tibetan history. 


\section{General Conclusion}

\section{Magical Emanations, Steadfast Incarnations \& Rule by Incarnation}

One of the most salient arguments of this dissertation is that trikāya theory as well as the notion of serial incarnation can be employed by traditions and their biographers for a number of purposes. Both of these tropes, for example, can be employed to argue for the exalted nature of a lineage's saints. Trikāya theory at its core, however, need not imply serial incarnation, for Śākyamuni-the nirmāṇa-kāya manifestation that established Buddhism in our world and the Buddha for whom trikāya theory was designed to describe - is not expected to return to human form. Through an analysis and comparison of biographical accounts of the Northern Lords that were written before and after the Northern Treasure Tradition unambiguously adopted the institution of rule by incarnation, it was possible to sort out the differences in the usage of the term tulku. In the earlier source, it was more appropriate to understand the term to mean "magical emanation" as it could refer to any of the manifold manifestations of buddhahood in human, animal, floral, or mineral form. Their comings and goings are similar to those of the sudden-appearing and sudden-vanishing rainbow and are correspondingly unpredictable. Even if a rainbow were to appear twice in the same quarter of the heavenly sky, it would be difficult to imagine how the two might be related or when, if ever, a third might arise. Equally apparent is the fact that these magical emanations are thought to arise in response to the specific needs of a specific time.

In the later sources, the term tulku is used to refer to "steadfast incarnations" that have been preserving and propagating the Buddha's teachings over hundreds if not thousands of years in both India and Tibet. While their initial appearance in earthly form may have manifested in the same magical manner as an emanation, the steadfast 
incarnation does not simply fade into the azure of the clear sky like a rainbow and effectively disappear. The steadfast incarnation intentionally stays within cyclic existence and therefore returns regularly to human form. Thus, it is possible to track the exploits of the previous incarnations, just as it is reasonable to expect that additional incarnations will appear in the future. Tulku are not trapped in the riptide of the samsaric ocean like the innumerable sentient beings that they seek to liberate, but are instead the masters of the ocean's currents and are thus able to surf the waves of cyclic existence from one life to the next.

The change in the doctrine of trikāya thus fosters an analysis of the authority of an incarnate lama to include both a synchronic and a diachronic dimension. A synchronic analysis directs our attention to the buddhalogically divine status of the tulku. They are earthly manifestations of enlightenment and are, therefore, ontological siblings of the most well-known of all the tulku, the historical Buddha. Diachronically, the development reflects the change in the understanding of a tulku from an entity that appears for only a limited amount of time before dissolving back into emptiness to a conception of an entity capable of serial incarnation. As such, they are now a suitable source of leadership that can be depended upon to maintain the stability of important Buddhist institutions. This change represents a significant innovation in the process of the routinization of charismatic authority in Tibet. A diachronic investigation also reveals the importance of transmission and training. Despite the elevated ontological nature of the tulku and the fact that he or she may have received the quintessential teachings of the tradition in many past lives, the new incarnate lama must also receive these same scriptural transmissions. Thus, the authority of the incarnate lama flows simultaneously through the incarnation lineage that dips in and out of human form, while also flowing through the transmission of 
teachings through the hearts and minds of living human vessels. Similarly, the ritual potency and authority of the incarnate lama must also constantly be refreshed in each life by receiving teachings and achieving mastery through extensive retreat practices.

Trikāya theory and the notion of serial incarnation are also employed in the narrative literature of the treasure traditions to support the authority of their treasure revealers. While such a strategy may involve the exalted ontological nature of a tradition's saints, the connection to imperial-era personalities and the circumstances of concealment are central within the context of the Northern Treasure Tradition. There are, however, a variety of possible methods for establishing this connection. Thus, while the most prominent argument in The Ray of Sunlight is that both Guru Rinpoche and Gödem Truchen are magical emanations that issued forth directly from Samantabhadra, Gödem Truchen is also represented as an emanation of Nanam Dorjé Dujom and in later sources as his reincarnation.

It has also become evident through this study that there is a group of practices or customs that generally accompany a robust example of the institution of rule by incarnation. There may be a regent to manage the affairs of the tradition between incarnations. Faithful disciples may pray for the speedy return of their masters. Visionary experiences may lead to the identification and recognition of new incarnate lamas. Candidates may be subjected to various memory-oriented tests that confirm one's status as a legitimate reincarnation. Recognized incarnations may be enthroned as the patriarch of a tradition and may be charged with maintaining the day-to-day affairs of an estate. The incarnate lama may also function as the most important lineage holder for an essential set of scriptures and practices. He or she may enjoy karmic relationships that have been maintained for many lifetimes. Each of these incarnate lamas may be involved 
in ensuring the continuity of the other lineages by acting as regents or through employing their visionary prowess in the process of recognition.

It should be acknowledged, however, that none of these strategies are unique to the institution of rule by incarnation and that not all of them need to be present for the institution to function. Many of the practices (e.g., regency and enthronement) that are a part of the system of rule by incarnation are clearly transpositions of succession customs related to the rule of royal dynasties. Some of the practices (e.g., the use of visionary experience and the importance of extraordinary feats of memory) appear to correlate to processes that are involved in treasure revelation. Others (e.g., scriptural transmission and prayer) are ubiquitous elements of the Tibetan religious environment. In the context of what is known as the institution of rule by incarnation, however, one finds that many of these strategies have been organized by the guiding principle of reincarnation for the purposes of maintaining institutional stability. ${ }^{218}$

218 This perspective has obviously been inspired by Davidson's excellent study of the origins of tantric Buddhism in India. See: Ronald M. Davidson (2002), Indian Esoteric Buddhism: A Social History of the Tantric Movement (New York: Columbia UP), 118144. 


\section{The Development of the Northern Treasure Tradition \& Methods of $(\mathrm{Re})$ Contextualization and $(\mathrm{Re})$ Appropriation}

The meditations of the previous chapters have resulted in a critical perspective regarding the development of the Northern Treasure Tradition. For more than two centuries after the death of Gödem Truchen, the tradition was maintained largely following the family-based customs of the Order of the Ancients. Throughout this period of development $\left(15^{\text {th }}-16^{\text {th }}\right.$ c.), the tradition maintained a variety of kama and terma transmissions and many of the patriarchs were treasure revealers that were recognized reincarnations of imperial-era figures. Through the efforts of a group of individuals, which includes Ngakgi Wangpo, Tenzin Norbu, the Fifth Dalai Lama, and Pema Trinlé, this family practice was removed from clan control and established as the Dorjé Drak Monastery, one of the six mother monasteries of the Nyingmapa Order. In conjunction with this transformation, the Lords of the Northern Treasures were recontextualized as the Wisdom-Holders of Dorjé Drak, and thus serial incarnation came to be central to matters of succession.

The methods that have been employed by hagiographers to recontextualize and re-appropriate the authority of Nanam Dorjé Dujom and Tropu Lotsawa took center stage in the second chapter. Because of their legitimizing potency, hagiographers of a multitude of loyalties employ various "lineage methods" to connect themselves with these important historical figures and thus establish a means to access the charismatic authority that is wielded by these figures during two of the most important foundational periods for Buddhism in Tibetan history. In each of the biographical sketches of these two figures, it is apparent that the hagiographers are employing the perceived sources of authority to 
legitimize the authenticity and purity of the teachings of their own tradition. In the case of the Northern Lords in particular, the authority of these past figures also lends legitimacy to their role as institutional leaders within the tradition. Moreover, the incarnation lineage as a strategy for the routinization of charisma represents a significant advancement over other forms of lineage because power ultimately passes through the ages in a single mind stream.

\section{Future Directions for the Analysis of Rule by Incarnation}

As stated in the introduction, this dissertation is intended to be a case study of one particular incarnation lineage to support additional studies of the institution. The following table consists of a series of analytical questions that are intended to guide the future analysis of other incarnation lineages and create a foundation for comparative analysis. The fact that the answers for each question are broken into three categories is intended to reflect the stages in the development of the Northern Treasure Tradition. While it may be the case that other traditions have not gone through the same stages of development, it is not uncommon for there to be a group of "preincarnations" that appear to have been retroactively appropriated by the tradition, a foundational or primary incarnation, and the later "post-incarnations" that continue the tradition. ${ }^{219}$

\footnotetext{
${ }^{219}$ Daniel A. Hirshberg (2012) employs this terminology in his excellent dissertation, Delivering the lotus-born: Historiography in the tibetan renaissance. (Ph.D. diss., Harvard University).
} 


\section{Guiding Questions for Analytical Inquiry and Comparative Analysis}

\begin{tabular}{|c|c|c|c|}
\hline & $\begin{array}{l}\text { (APPARENTLY) } \\
\text { RETROACTIVELY } \\
\text { CONSTRUCTED } \\
\text { STAGE }\end{array}$ & $\begin{array}{l}\text { DEVELOPMENTAL } \\
\text { STAGE }\end{array}$ & RobUSt StaGE \\
\hline $\begin{array}{lr}\text { WHEN IS } & \text { THE } \\
\text { INDIVIDUAL } & \text { FIRST } \\
\text { CONCEIVED AS } & \text { AN } \\
\text { INCARNATION } & \text { WITHIN } \\
\text { THE LINEAGE? } & \\
\end{array}$ & $\begin{array}{l}\text { Retroactively } \\
\text { claimed by } \\
\text { hagiographers }\end{array}$ & Enters as an adult & Enters as a child \\
\hline $\begin{array}{lr}\text { ARE } & \text { THERE } \\
\text { PREREQUISITES } & \text { FOR } \\
\text { CANDIDACY? } & \\
\end{array}$ & N/A & $\begin{array}{l}\text { Is an initiate or } \\
\text { master of the } \\
\text { transmission lineage }\end{array}$ & $\begin{array}{l}\text { Shows signs of normal } \\
\text { mental and physical } \\
\text { development }\end{array}$ \\
\hline \begin{tabular}{ll}
\multicolumn{3}{l}{ WHEN IN THE LIFE OF } \\
THE INDIVIDUAL IS HE \\
OR SHE & FIRST \\
(UNOFFICIALLY) & \\
IDENTIFIED? &
\end{tabular} & $\mathrm{N} / \mathrm{A}$ & Identified as an adult & $\begin{array}{l}\text { Identified as an infant } \\
\text { or a child }\end{array}$ \\
\hline $\begin{array}{l}\text { WHEN IN THE LIFE OF } \\
\text { THE INDIVIDUAL IS HE } \\
\text { OR SHE OFFICIALLY } \\
\text { RECOGNIZED? }\end{array}$ & N/A & $\begin{array}{l}\text { Recognized as an } \\
\text { adult }\end{array}$ & Recognized as a child \\
\hline $\begin{array}{l}\text { HOW IS } \\
\text { INCARNATION'S } \\
\text { STATUS PRIVATELY } \\
\text { CONSUMMATED? }\end{array}$ & N/A & $\begin{array}{l}\text { Recovery } \\
\text { memories of past } \\
\text { lives }\end{array}$ & $\begin{array}{l}\text { Successful completion } \\
\text { of a series of tests that } \\
\text { involve } \\
\text { memories }\end{array}$ \\
\hline $\begin{array}{l}\text { HOW IS } \\
\text { INCARNATION'S THE } \\
\text { STATUS SOCIALLY } \\
\text { CONSUMMATED? }\end{array}$ & $\mathrm{N} / \mathrm{A}$ & $\begin{array}{l}\text { Recovery of } \\
\text { memories is the } \\
\text { consummation of } \\
\text { incarnation status }\end{array}$ & $\begin{array}{l}\text { Enthronement is the } \\
\text { consummation of the } \\
\text { incarnations status }\end{array}$ \\
\hline $\begin{array}{l}\text { WHEN ARE } \\
\text { ESSENTIAL TEACHINGS } \\
\text { TRANSMITTED TO THE } \\
\text { INCARNATION? }\end{array}$ & $\begin{array}{l}\text { It is possible that } \\
\text { the individual did } \\
\text { not receive the } \\
\text { transmission. }\end{array}$ & $\begin{array}{lr}\text { Incarnations become } \\
\text { masters of the } \\
\text { essential scriptures } \\
\text { before } & \text { being } \\
\text { recognized } & \text { as } \\
\text { incarnations } & \end{array}$ & $\begin{array}{lr}\text { Incarnations } & \text { are } \\
\text { unofficially } & \text { identified } \\
\text { and/or } & \text { officially } \\
\text { recognized } & \text { before } \\
\text { receiving transmission } \\
\text { of the r essential } \\
\text { scriptures }\end{array}$ \\
\hline
\end{tabular}




\begin{tabular}{|c|c|c|c|}
\hline $\begin{array}{ll}\text { WHAT IS } & \text { THE } \\
\text { RELATIONSHIP } & \\
\text { BETWEEN THE } & \text { FAMILY } \\
\text { OF THE PROSPECTIVE } \\
\text { INCARNATION AND THE } \\
\text { EXISTING } & \text { SOCIAL } \\
\text { INSTITUTION? } & \\
\end{array}$ & N/A & $\begin{array}{l}\text { Incarnations are } \\
\text { selected from among } \\
\text { close disciples or kin }\end{array}$ & $\begin{array}{l}\text { Incarnations } r \text { are } \\
\text { identified within other } \\
\text { families, possibly } \\
\text { aristocratic lay } \\
\text { families, and perhaps } \\
\text { for political purposes }\end{array}$ \\
\hline $\begin{array}{l}\text { WHAT IS THE ROLE OF } \\
\text { REMEMBERING PAST } \\
\text { LIVES? }\end{array}$ & N/A & $\begin{array}{l}\text { Memories of past } \\
\text { lives are awakened as } \\
\text { adults }\end{array}$ & $\begin{array}{l}\text { Memories of past lives } \\
\text { need not be lucidly } \\
\text { recalled }\end{array}$ \\
\hline $\begin{array}{l}\text { HOW MUCH TIME IS } \\
\text { THERE } \\
\text { INCARNATIONS? }\end{array}$ & $\begin{array}{l}\text { Large time gaps } \\
\text { between } \\
\text { incarnations }\end{array}$ & $\begin{array}{l}\text { Time gaps of various } \\
\text { lengths }\end{array}$ & $\begin{array}{l}\text { Short gaps between } \\
\text { incarnations }\end{array}$ \\
\hline $\begin{array}{l}\text { WHAT IS THE NATURE } \\
\text { OF THE INCARNATION } \\
\text { LINEAGE'S } \\
\text { STRONGHOLD? }\end{array}$ & N/A & $\begin{array}{l}\text { No clear seat. There } \\
\text { is a monastery } \\
\text { associated with the } \\
\text { incarnation, but it } \\
\text { does not rely upon } \\
\text { them for leadership. } \\
\text { The incarnations } \\
\text { appear to travel in } \\
\text { pursuit of patronage } \\
\text { opportunities. }\end{array}$ & $\begin{array}{l}\text { Existence of an } \\
\text { endowed estate as the } \\
\text { permanent residence } \\
\text { of the incarnation }\end{array}$ \\
\hline $\begin{array}{l}\text { WHAT IS THE } \\
\text { RELATIONSHIP } \\
\text { BETWEEN VARIOUS } \\
\text { INCARNATION } \\
\text { LINEAGES? }\end{array}$ & $\begin{array}{lr}\text { A group } & \text { of } \\
\text { imperial-era } & \\
\text { incarnations are } \\
\text { involved in } \\
\text { concealment } \\
\text { treasures }\end{array}$ & $\begin{array}{l}\text { A group of different } \\
\text { incarnation lineages } \\
\text { succeed one another } \\
\text { as independently } \\
\text { sovereign patriarchs } \\
\text { of the tradition }\end{array}$ & $\begin{array}{l}\text { One incarnation } \\
\text { emerges as the } \\
\text { ultimate source of the } \\
\text { patriarchy }\end{array}$ \\
\hline $\begin{array}{lrr}\text { WHO MANAGES } & \text { THE } \\
\text { AFFAIRS OF } & \text { THE } \\
\text { INSTITUTION IN } & \text { THE } \\
\text { ABSENCE OF } & \text { AN } \\
\text { INCARNATION? } & \end{array}$ & N/A & $\begin{array}{l}\text { The eldest patriarch } \\
\text { of the tradition or the } \\
\text { most experienced } \\
\text { student of the } \\
\text { previous incarnation }\end{array}$ & $\begin{array}{l}\text { A regent that only } \\
\text { temporarily retains } \\
\text { power and is involved } \\
\text { in the recognition and } \\
\text { enthronement of the } \\
\text { next incarnation }\end{array}$ \\
\hline
\end{tabular}

Many of the observations listed above are rather straightforward. For example, the existence of an endowed estate that serves as the permanent residence of the incarnations of the lineage is a strong characteristic of a robust social institution. It reflects the acceptance of the incarnation lineage as a legitimate social entity capable of owning property and lands in a manner that transcends the normal limitations of the human 
lifespan. In this respect, the establishment of an endowed estate is akin to the process of incorporating, transforming a multitude of interchangeable parts into a greater whole.

A related observation concerns the length of the gaps between incarnations. In the foundational stage, or perhaps in its retroactively revealed stage, the existence of large time gaps between incarnations is not a subject of concern. When an incarnation lineage is in its robust form, however, large time gaps are problematic because the presence of the incarnate lama is an essential component of the power structure of the social institution that is built up around the lineage. In fact, the fear of ensuing institutional disorder as a result of the absence of important incarnate lamas is a very real and continuing concern. This type of anxiety was likely one of the primary reasons that the Fifth Dalai Lama's death was hidden for fifteen years. There have also been many instances when the succeeding incarnate lama is identified prior to the passing of the previous incarnation. Despite the obvious ontological and philosophical problems that are suggested by having two incarnations present at the same time, it is an acceptable alternative to the possibility of having none at all.

One discovery that continues to fascinate me is that several of the incarnate lamas that lived during the developmental stage of the lineage were identified not as children, but as adults. These individuals reached their majority prior to encountering the Northern Treasure Tradition. After making contact, however, they were initiated into the transmission lineage and became masters themselves prior to being singled out as incarnations of the founders of the tradition. I initially thought that this implied that those individuals were only understood as incarnations retroactively. While this may certainly be the case, it is more likely that the incarnation model of leadership was beginning to influence the tradition at this time, and thus the patriarchs may have been identified as 
incarnations in their own lifetimes but only after becoming the patriarchs of the tradition based on their own merits.

Furthermore, although the awakening of latent memories from past lives does not turn out to be a necessary condition for the consummation of one's status as an incarnate lama, it is still implicitly exalted as the ultimate form of validation. Many incarnate lamas throughout history have struggled with issues concerning their own personal identity. Once an incarnate lama is publically consummated by way of the enthronement ceremony, there are few that would question his or her legitimacy. Nevertheless, such outward forms of verification may not settle the issue within the incarnation's own mind. It is the recovery of latent memories of past lives alone that can remove all doubt once and for all. Pema Trinlé, for example, is aware that Lekden Dorjé was able to awaken his own memories as a result of intensive practice at the original epicenter of the Northern Treasure Tradition. As soon as he retires as the acting head of the Dorjé Drak monastery at age fifty, Pema Trinlé's first action—quite possibly his first completely self-interested life decision - is to undertake the arduous year-long journey to the lands where his previous incarnations revealed and propagated the Northern Treasures. It is likely, that he too sought to confirm his own identity as an incarnate lama by recovering the memories of his life as Lekden Dorjé, Gödem Truchen, or even Nanam Dorjé Dujom.

Ultimately, serial incarnation is profoundly fascinating not only because it is a transformative doctrinal and social development within the context of Tibetan Buddhism, but also because it uniquely addresses the ultimate human mystery of life after death. Despite Buddhism's emphasis on the absence of a true and eternal self for both ontological and soteriological reasons, it does appear that there are some individuals who are able to maintain at least some part of their personality from one life to the next. 
Moreover, the ultimate proof of life after death is the recovery of past-life memories. And, while it still may be true that you can't take it with you, it seems that some can leave it here and come back for it later. 


\section{Appendix I: Translation \\ The Clear White Mirror: The Autobiography of Pema Trinlé}

\section{The Destination and the Family}

I was to be born in the castle called Namsé Ling in the region of Mönkhar, which is on the southern bank of the gently flowing Rohita River. It is within the greater region of Central Tibet and it is to the west of both the great Samyé Monastery and the Tradruk (khra 'brug) Temple. It is said that long ago, there was a lineage of religious kings that had been exiled in the land of Mön. Later, they came to reside in this area. [T6] ${ }^{220}$

Everywhere the land was marvelously pleasant. There were connected swaths of pleasure groves and forests, peppered with many fruit bearing trees. There were medical plants, ponds, and smaller pools. There were barley fields and rings of small villages. There was game and so many people that there were pleasant sounds [like] those of [melodious birds]. [Nestled] between the wall of the mountain and the meadows below, where the sounds of the river can be heard, was the famous castle of Namsé Ling. There was a great archway and a great opening for light, and it was encircled by a ring of high battlements. Many great masters had scattered the flowers of benediction there hundreds of times, and thus the castle was endowed with auspiciousness.

\footnotetext{
${ }^{220}$ This translation begins on the fifth page of the manuscript that was scanned in 2003 by the Tibetan Buddhist Resource Center, which I refer to as the T manuscript. I have elected to omit the introductory verses that appear on page $\mathrm{T} 4$.
} 
My clan was essentially a part of the Lha (lha) clan, but more specifically the paternal blood line of my father, Lord Karma Püntsok, was said to include religious kings and the maternal blood line of my mother, known as Lady Rindzin Butri, passed through the sons of the mad saint Druknyön Künlek ('brug smyon kun legs). [Perhaps it was because] my parents revered all religious systems without bias that they tended toward virtuous activities, and were of strong and marvelous faith. Some understood [their blessedness] primarily as a fruit of the causes and conditions of the past activities of each of them.

\section{The Regency of Yölmopa Tenzin Norbu}

Then, after Ngakgi Wangpo himself departed into another realm on the eleventh day of the second month of the Earth-Rabbit Year (1639), the great religious sovereign named Yölmopa Tenzin Norbu himself become the regent of the monastic community of Tupten Dorjé Drak. [T7] And as he sat upon the lion's throne on the first day of the eleventh month of that year, that holy lama himself wrote the following words:

\section{Excerpt from the Autobiography of Yölmopa Tenzin Norbu}

[His] form body [that] tames migrators is like the sun,

And although at the moment it is setting in the reality body of the sky,

[His] compassion is perfectly complete, like the [full] moon,

And it manifests to purify the sentient beings of the six realms.

\section{The Prophetic Vision}

I had the following dream during the first night of the eleventh month. The main part of the valley was behind me in the south and the lower part of the valley was [in front of me] in the north. A great river flowed to the East. There were various [clearly 
defined] meadows and barren swaths of land. Nestled within the rugged red rocks on the right side there was a monastery, and along the left side, where the mountain and the plains met, there was a grove of bamboo that seemed to extend far across the middle. The tributaries were like playful maidens bringing melodies as they passed. And before this yogin, the billowing image made the sound of jingling bangles. As they went winding past, [the sounds] gave me pleasure. That is how [the vision] of the land came [to me].

Then, the entire sky turned white because of an immense light, [and I remember] pondering about what was happening. Appearing close to me in the center of the sky was the sphere of the moon. [It was like] a pool twice encircled by the five-colored lights. From the left hand side, the length of a luminous beam made of the five lights was drawn out and its extremity pierced the circumference of the moon and the base pierced the front of me. [T8] On the left, there was a great victory banner with a little blue on the top and red below. From both [parts of the victory banner] there were fringes of the fivecolored lights. Then I had the thought that I had never seen anything as auspicious as this before.

Then, my lama was sitting on top of the moon disc and I was thinking of how great it was. The pale-white light was so great that I was all but unable to see. Still, I looked insistently. The peaceful land was displayed as if it was carefully drawn with ink [before me] and it was an immense experience. Within that land there was a house that looked like it had a Chinese style roof. My lama himself, Ngakgi Wangpo, was [outside near the house] adorned with the snow-melt monk's robes. In one hand he held a golden 
vajra and in the other he held a ritual vase for the Great Guru Treasure. ${ }^{221}$ Because his image was mingled with the pale-white light, it was as if it came down even to color his complexion, clothing, and the rest. The pale-white light was intense and [it was within him]. It was as if our great unbearable misery and his happiness competed with one another. From this state I arose at once and pressed my palms together and bowed to him. I said, "Rindzin Ngakgi Wangpo, look upon me with your compassion!" [My lama] gave a fervent roar, and while [listening to the bellowing], I awoke from sleep.

I prayed thus:

In the beautiful sky, which is the stainless faith of my lama, [T9]

Was the moon of compassion, which was like a vast mirror.

I think this means that I will meet my lama again.

If I were to establish a real connection [again], how great this would be!

Oh, pure vision of the Yölmopa incarnation!

Although guised as a beer-drinking woman

If I am faithful, then it will happen as [predicted].

Oh, the compassion of my absent lama!

${ }^{221}$ A treasure revealed by Trashi Topgyel. 
But still I wondered how you would come. I immediately wrote down the dream in my own hand and understood that [the dream] meant that the Lama Rindzin Ngakgi Wangpo himself would be reborn in a land just like the one in the dream. At dawn on the seventeenth day of that [eleventh] month, [I] wrote a rough draft of the following prayer for the speedy return of the Victorious Rindzin's rebirth entitled The Crown of the Crescent Moon (zla tshes gsar pa'i cod pan):

\section{Speedy Rebirth Prayer}

Your dance is an emanation that subdues and dominates all men, You manifest peacefully or wrathfully as you will, How you will manifest as the lama and hold dominion, I praise the song of Ngakgi Wangpo!

Always but following after the sentient beings of the six realms, Manifesting in a physical form that [embodies] measureless compassion.

You are like a refuge and protector for beings without respite. You are like our deliverer.

Cross over the river of birth, old age, sickness, and death again! Thou! Through your powers enter the world.

If I could meet your worldly deed, whatever teachings you give, Just a little bit of your life, Lord Rindzin!

[Hear our] harsh and tormented sounds of deep despair, 
Although it is an unworthy song, [T10]

I have seen in the peaceful expanse of my dream, the assemblage of your physical form.

We zealously pray [that it happens thus]!

Victor of the Universe! One father! Primordial Protector!

Manifest as a son of the victorious ones even now!

Train this community of stubborn and impure sentient beings!

Express your kindness in the form of the extensive teachings of the supreme vehicle!

In the sky of the dharmakāya was the moon of your form body [harkening] a new day.

From then, [may time] pass quickly and [my lord] himself appear.

Like the vision of the bright light, may your entrance into the womb be unhindered, and

May the compassionate one dispel the darkness in the mind of this migratory being!

May the engendering of the son of the victorious one be well done, and Through my pure prayers, may his mother and father be blessed! Remember your pure children for whom you have done so much. Please quickly cause the appearance of your incarnation. 
Created by his family, [his body] will be a mandala with hundreds of major and minor marks.

The face of the incarnation is written in my mind, so beautiful and young. Until that time that I obtain that delightful feeling [of actually seeing you], May you be victorious over the battles and obstacles to our meeting!

Oh, Dorjé Dujom! Oh, Gödem Truchen!

Oh, Lekden Dorjé! You are in their [incarnation] lineage!

I follow you continually in my training, studying, meditation, accomplishments, and prayers.

With your blessings, may I continue to progress without corruption!

You are the mentor with whom I have connected through innumerable births!

With these true words I pray that your compassion is quickly aroused.

By the truth of the exalted mind of the Knowledge Mantra Bearer, Sākya Zangpo, May it be just so! [T11]

Although I thought to write it just like that, I did not have the time [to finish it and so it] remained [like that] for a while. In the meantime, I was encouraged [to complete the prayer] by my ardent vajra brothers.

\section{The Struggle to Interpret the Signs of Prophecy and Dream}

I had had a dream in which the Victorious Rindzin showed me the prophecy through signs and he had also previously said, "Because you are very knowledgeable, my protégé, the Yölmopa incarnation, you will author [the speedy rebirth prayer] near dawn 
on the seventeenth day within the lama's chambers." Then, having established the recitation of these verses by the assembly, the Rindzin Yölmopa recited the longevity statements himself. Like that, he acted in accordance with the pith meaning that had arisen in the form of his pure vision of the circle of the moon and supplicated [the master] in the manner of the liberation story of Rindzin Ngakgi Wangpo entitled The Wondrous Ocean. ${ }^{222}$ In that it says:

In the vast sky of the virtuous and faithful vision, and Within the rings of the five colored lights, In the center of the expansive mandala of the moon, You will pray to be clearly shown my own face.

I set down on paper what happened in those pure visions. I then gave instructions to Lama Zurchen Chöying Rangdröl himself, who was the principle disciple of both myself and my master, for a painted scroll to be created. [T12] As for the way things went, although when he analyzed with his heart he understood [the vision] to mean that the rebirth of the Rindzin Ngakgi Wangpo will come quickly, [he was troubled by] the tip [of the bow and arrow that possessed] the five colors of the rainbow and pierced the front

${ }^{222}$ This is the biography that was authored by the Fifth Dalai Lama. It is here called: Inam grol chos dbyings. 
of the Wisdom-Holder Yölmopa. He feared that it meant that the Wisdom-Holder Yölmopa himself as well would quickly pass.

\section{A Letter Expressing Zurchen Chöying Rangdröl's Interpretation}

[Thus], in so many words as follows, the Lord Zurchen sent him a letter praying for [Yölmopa] to release the essential meaning of the pure vision:

The wind and the rain is the call of the coming spring

That carries the burden of the most subtle dust.

But this one follows after ghosts that are composite images, Which will not lead to faculties that produce clear sight.

If you do not release [your interpretation] of the meaning of these sign, then there will be sadness within your happiness. In my own mind, however, I think that perhaps if the power of the good deeds of sentient beings were to increase [like the light increased in your dream], the Victorious Rindzin will be seen sitting there [and we will see him come] from the moon disc and reside here in the taming field. The region corresponds to [the surrounding area].

The image was in the likeness of the supreme lord regent, which was the moon of the enlightened mind. As for [the land] with its tributaries, it was the river, which made the sounds like bangles. The bow made of the five-colored lights shining in between the mandala of the son was like [empty attachment]. And it meant that the five-fold wisdom of the Victorious Rindzin entered into a physical body. [T13] 
As for the connection [made by the pillar in the dream], it was a sign that the pair of incarnations, as father and son, will do the work of spreading the teachings of sutra and mantra. [This was also shown by the] appearance of the small and large victory banners of light. The ocean of reeds symbolized that he will live in accordance with the songs of liberation and grasp the meaning of the essence-less-ness of cyclic existence. It is a weak minded thought that the omen for entering into retreat [could be interpreted as meaning], "[Yölmopa] must enter into the state of primordial awareness." I have a weak understanding [of this prophetic dream].

\section{A Letter Expressing Yölmopa's Response to his Disciple}

[Yölmopa] replied that [Zurchen Chöying Rangdröl] should have courage and not [despair]. Because he did not possess understanding or vision by means of the two types of understanding, he considered [how] to unravel the signs. The Rindzin Yölmopa later wrote this [letter for] releasing the meaning of the pure vision [that had come to be known as] Heruké Tsamdrö (he ru ka'i 'tshams 'gros):

Just as the faithful farmer plants this and that in the fertile earth, And this results in all varieties of fruits and vegetables, All that actually attains existence comes from the ground.

Although this is the case, [you] didn't think [it through with enough belief and virtue].

Just so, the deluded person [intends] to destroy delusion, but 
Usually the deluded person just engenders [more] delusion.

It is the holy path, with its amazing blessings,

That indeed [brought about] the deluded visions of the dream.

[Then, Yölmopa made the following] promise: "Although it is difficult to give an exact interpretation of my vision of the victorious Rindzin, which [I call] Moon-Mandala, since you have nevertheless asked me what I think about this [dream], you have produced in me [the excessive] bravery [required for me] to express [the meaning for you].

As for the mountain of pride of this greatly learned, righteous, and accomplished [master], [T14]

I have made it perfectly clear that to the throne that he himself established, The Dorjé Rindzin, through his peaceful resolve, will pay homage.

I am possessed with unshakable pride in my lama.

By the little bit of him that I saw and heard, I remember my lama.

He had the ability to gloriously maintain renunciation, realization, wisdom, and compassion.

Though it was a bad time period with a proliferation of people who were full of pride and envy, You, the supreme Rindzin were untouched.

Although I have not had the fortune to actually commune with you for some time, [I know that] the master of bliss and all the rest abides in the realm of azure. 
In just those expressions of the realm of form that are pleasant and unpleasant, The fantastic vision was seen by the power of the pure mandala of the moon.

And then dawned [the visions of] the nurturing lands, the boulders, and the monastery

The [water] going down the winding tributaries and the ocean of reeds, and Then the mighty river and the rest of the wondrous omens. I wonder if I can decode these signs.

It is known that the word "moon" in the end means penis [or something masculine].

Likewise, it is known that [the word] "reed" is feminine.

In there is something to be connected with the letters of these names, There is certainly something that will come out of this wise method [of investigation].

Appearing within this expansive moon, there was the shape of a pleasant village, This is the actual village of the moon-prince.

I wonder if I have seen anything like [it].

It did not come to mind [whether] it was India, Nepal, or China.

The white sky was the dharmakāya, the protector of the night, And the two rainbow-[rings] that were with it were the saṃbhogakāya. The completely clear vision of the body of the victorious Rindzin 
Logically appears to signify the compassion of the incarnation. [T15]

As for the beautiful scenery and the river and tributaries,

That were flowing by, they were just so beautiful.

I think it means that [my lama] will arrive in an area

That is concordant with that place or somewhere similar.

It is known by both enemies and champions [of the Dharma],

That the untainted elixir of the beautiful doe descends to the tip of her utter.

[Just so,] many filled vessels are poured in to overflow the cavity of

A suitable copper or silver cauldron. What of those things

can misguide [the river]?

Through skillful means and skill in interpreting signs,

Both categories of investigation are used to determine where the sprouts of all the victorious ones will arise.

In terms of our investigations, you and I are the same in our conclusions

Regarding the wondrous abode [where my lama will be born].

As for the bow, it is the supreme bow carried by Indra, And this subject of it piercing the front of me, my friend, Although you are a little fearsome, if we are to examine this correctly, It has a situational and an ultimate [meaning]. 
The five wisdoms were actually [represented] by the marvelous character of the five lights.

It was an example of how [wisdom] lassos the heart of Vajrasattva.

The piercing through the front of me [represents] the situation of loving attachment to us.

Indeed, this is [a sign] that [he is] our protector.

By this body of light he was cleansing the impure world.

The four visions of attainment [signified] that I had not yet reached the end.

That which looks like a great shield and a singular sword clearing and remediating And Vishnu's sagely pride of one hundred thousand.

At this time, these heavy remains are like a snake skin [T16]

When it is time to cast it away, there will be all kinds of visions of fear and dread. And when my little bit of flesh has been torn apart, [I'll hear]

The sound of the vulture, "Pam! Phat! Ha! Ha! Hi! Hi!"

The dharma-body of [the old master] had transcended dualistic reality.

The emanation-body of [the old master] could indeed be seen in the youthful body.

The enjoyment-body of [the old master] [was in his posture], and It appears to me that there signs have been interpreted [correctly] without a doubt. 
The moon was like the old man residing in the house

It was like a mudra signifying an effigy of life

The light of compassion extended far and entered me

And it doesn't appear that I have the zeal to continue on the path.

As soon as that happens, I will enter into the fifth state.

[This is what] the signs show me. Either way,

Possessed of faith, one's like you, will perform small enlightened actions.

[While I] rest in sleep in the central channel in the state of bliss and emptiness.

Although I had attained an indestructible belief, there was such a burden those days that I had become a white old goat within a flock of sheep. Having been exhorted by my religious friend, [Lord Zurchen], I sent [this letter] in order to reveal the meaning of my sacred vision.

\section{Conclusion of the Excerpts from Yölmopa's Autobiography}

These quotations I have written here as I saw them actually written as a way of introducing [this autobiography].

\section{Prophecy \& the Karmic Relationships}

During his previous lives, the Sovereign of the Accomplished Ones, the Great Treasure Revealer, the Third Yölmopa Emanation, Tenzin Norbu himself, [served] before Guru Padmasambhava as the one known as Pema Gungtsen, the religious minister of [King Trisong Detsen]. In many garlands of the stories of a succession of lives, [Tenzin Norbu] was connected like that as master and disciple to the Wisdom-Holder Ngakgi 
Wangpo and [Nanam] Dorjé Dujom. [T17] In particular, the master of mantras Śākya Zangpo and Lekden Dorjé were interrelated in that they arose as master and student.

This last time around, Rindzin Ngakgi Wangpo and Rindzin Yölmopa arose as master and disciple. They were held together through treasure prophecies, [just as in] the uncountable amazing liberation stories of [many] individuals. This is especially clear in the liberation story of the accomplished one, Rindzin Yölmopa, [and] many other inner and outer liberation stories.

Due to [his] possession of the sight of the wisdom of the three times that cannot become obscured, how could we have any delusions regarding the making of the prophecy of the reincarnation of the Rindzin Ngakgi Wangpo?

\section{The Importance of the Autobiography}

However, as for the thought that even the deeds of this life are senseless and that sentient beings possess all kinds of fetters, there is no need to doubt. Although this is clear to all, [we often] compress things thinly into the garlands of the stories of the successions of lives. And thus there may be [inadvertent] insults of gods and higher beings. However, despite my proportion of permanent restraints, as I am without aspiration and devoid of the qualities of renunciation, I myself am the successor who teaches and protects the lion throne of [the Tupten Dorjé Drak]. Without a doubt there are scattered in my own continuum a few seeds of enlightened activity.

\section{The Pregnant Mother}

In this next section, [I will discuss] the establishment of the Kong district [as] what manifested just so in the pure vision. It simply corresponded very clearly with the mountains and valleys of Mön Castle, the monastery [there], the [bamboo] grove, and so 
forth. In that [region], I entered my mother's womb. [B21] $]^{223}$ Then, when my mother, Lady Rindzin Butri, became endowed with a sentient being [in her] womb, that matron herself came to Lhasa with the intention of communing with the Jowo Sākya [statue]. When [she was on her way], as soon as she saw the monastery and holy places of Dorjé Drak from the wharf at the tip of the southern side of the Drichu River, a strong [feeling of] remorse [and] the [desire for] renunciation were born [in her]. As her outward behavior was such that she experienced the arising of occasional inexplicable crying, she seemed to experience all kinds of emotions disruptions. With respect to her behavior, the male servants had certainly become suspicious.

Although that matron herself composed a manuscript, the few parts [recounting her real-world experience] are [nearly] incomprehensible. There are indeed many amazing dreams [recorded in it], such as the occasion when she went into a rainbow and others such as when she penetrated into a dome of light. All that remains, however, I have not understood and cannot find separation between the truths and falsehoods. When I was in the womb, I was composed from internal [factors of] that sentient being's past. [B22] In my mother's mind, there arose conceptual impressions as if I were explaining the reading transmission of the Vinaya and so forth.

${ }^{223}$ There is a missing page in the T-manuscript between the seventeenth and eighteenth pages. Thus, the following section is based upon the B-manuscript, and I have, therefore, listed the page numbers from that manuscript for this section. 


\section{The Night before the Return of the Lord}

When the moon of the $O$ [dbo] constellation (i.e., the eleventh month) appeared in the year [1641], I had completed the [required] number of months in the womb and the time was ripe for being born. At that time, through the power of our previous aspirations and merit, the great Rindzin Yölmopa, [Tenzin Norbu], came to Namsé Ling along with an assembly of monks from Ewam Chokgar. On the second day of the eleventh month, [my mother] was appropriately [seated] and abided comfortably without any discomforts of child birth.

[Tenzin Norbu] summoned before him the one called Yangchen (dbyangs can), who would later by my nanny, and she heard him say: "Take this blessed butter and also this protector [amulet] that has been put together in a manner appropriate [for the situation] because the physical form of my master will probably be reborn just this evening. [For] the splitting of the cervix [i.e., the actual moment of birth], which will occur due to the collected [past] actions of my perfectly complete Rindzin Lama, bestow [to the child and mother] a few blessed butter [figurines] made into the shape of small fish and this iron spike." [B23]

At that time, the matron [mother] wondered [with skepticism] in her heart-mind, "As I am now without any [physical difficulties associated with immanent childbirth], how could [the baby] be born so suddenly?" Indeed, she felt only disregard for the lama [at the end of the day]. 


\section{1 - Year of the Iron-Snake - Eleventh Month $-3^{\text {rd }}$ Day The Birth of the Lord}

That evening, she was oppressed suddenly with birth pains. On the third day of the convergence of that constellation, which was a Thursday, I was born. At the same time, they heard thunder, which was a sign.

It [also] occurred on the third of the month that the Rindzin Yölmopa [ordered] the arrangement of [a ritual performance] in accordance with the Lhagyel (lha rgyal), which is the performance of a juniper burning rite (lha bsangs) [involving] the three exclamations of "Lhagyel! Lhagyel! Lhagyel!"

\section{Corresponding with the Regent Yölmopa}

Just after I was born like that, there was the reporting [to Yölmopa] of the way [the birth occurred] and the setting into motion of the [official] name request. One called A-bar Trinlé was sent before [Yölmopa], where he was given a [special type of] offering scarf. [T18] [Yölmopa] asked, "What is your name?" [The messenger] replied "Trinlé." [Yölmopa] was heard saying there at the head of his assembly of monks: "[Your name is] an auspicious connection [meaning] that the rebirth of my lama will come to have great enlightened activity." The following was expressed in a naming letter:

[The name shall be]: Karma Tsewang Püntsok

Since we have discovered that [there were] auspicious signs, such as the consensus [according to those near the birth of this child] that the first thunder of 
the year [was heard at least] three times, I am rather sure that [the child] is a great person. [You] need to make him as ritually pure as possible."

He actually composed this letter that I now hold in my hand as a relic.

Then, not long after I was born, [Yölmopa came and] issued a few empowerments and teachings such as a longevity blessing and the Guru Drakting (gu ru drag mthing) to the mother and child together. Not long after the holy lama suddenly returned to his own abode. Then, he issued a letter of official decree to my mother in these words:

With respect to Lady Rindzin,

The reason for sending [this letter] is that that son [of yours] has been prophesized by Avalokiteśvara as being the emanation of my lama. Preserve the connection between this boy and his cleanliness with secrecy and hiding from other people. I request that even that spike you keep in your mind. I am presenting you with cardinal details. The gift is this basket, which [contains] a treasure of pearls.

I have written this here [copying] from the actual letter.

\section{The Obstinate Karmapa}

Because at that time the Victorious Karmapa, Chöying Dorjé, was residing in Yardrok Karmo Ling, [someone] was sent to request a name for me. [T19] He sent an official decree that said, "Now is not [the right time to clarify] the child's name." A story 
also appeared, which [irritated my mind], that said: "Although he is one who knows [all] clearly, [he] [couldn't] send even a name to [this] child."

\section{Encounters with the Regent Yölmopa}

After a long time, Yölmopa himself came to Namsé Ling. Several [people], such as our shrine master, say that he first fulfilled the wishes for empowerments, teachings, protection, and exorcisms of the head monks. Then Yölmopa gave empowerments for many different cycles and types of practices, which were transmitted especially for me. Although I am not certain about which empowerments [were given], I remember these days. He was sitting near to a row of three windows looking east of the [highest room] of the estate while the lama himself was looking north. He had a great measure of dreadlocks and wore earrings on his long earlobes. He rolled a [large-beaded] rosary of sandalwood in his left hand. I remember clearly his face and so forth as he was giving the empowerment. It has come up [again and again as] a way of speaking — [from mouths of] my mother and others - that I climbed into his lap and did things like touched [his bell].

Then, while this master of the cremation of [Ngakgi Wangpo] was doing [these empowerments], he rolled some pills [made from Ngakgi Wangpo's skullcap] into the eastern door of the crematorium, and [Yölmopa] said: "[This] old man [Yölmopa] will return quickly [and] although [I] will place this vase on top of [your] head, I don't know how long this old person will remain [on this earth?]." [T20] Not long afterwards, we gathered together [all] the images of his physical form. Although for us [we had] the good fortune of obtaining [the nectar of his speech] from just those [experiences retold above], the mentor that I met at the beginning of the [specific] path in this life was [nothing but benevolent]. I even said this: 
My previous actions [were like] seeds in my parent's good field.

By the blessings of accomplished one, [which is like] the supreme moisture of rain, and

His compassion, [which is like] the heat of light rays, [the seeds] have matured, And thus the freedom and leisure [appropriate for a high lama] have sprouted [like] new shoots of bamboo.

The teachings of the victorious one included monastic discipline, learning, and studying,

Explaining, listening, meditating, and detailed sādhanā practice.

Having become aware of the actuality of the gods, the positive forces of accomplishment,

The victory drum's beat of summer responded three times.

From the magically manifested army of discordant demons, Emerged an exalted deity embodying all of the manifestations of Indra, An actual manifestation of the Great and Glorious Vajrakumāra Like the refuge of a constructed statue that frightens away disease and negativity from children.

Rindzin Yölmopa, while wearing his ritual headdress, Drew from the pure continuum of the river of ripening empowerment And planted the seeds of the four bodies of the Vajrayana 
In my mind stream and I was completely purified of the defilements of the womb.

O protector! Grow like the village sugarcane of a Sri Lankan village, May you rapidly ascend the glorious mountain on the southern continent! Although you set off while I was a child, through the power of this prayer I make this aspiration that we are united in the future! [T21]

\section{$1642 \& 1643$ - Years of the Water-Horse \& Water Sheep Early Childhood: Ages 2 and 3}

Having generally behaved in the manner of a [normal] child, there was no reason [to believe that this] good and wondrous liberation story could have occurred [in my previous life]. However, I was well protected by both my mother and father, and although I did not have a wet nurse, I had a nanny named Yangchen who always held me on her lap. Other than them, my own older sister named Gögö and others were my immediate nurturers, together with an elderly monk who was our maid servant. Between the ages of two and three, I passed the time enjoying myself as all children do. Having gradually become [more mature], there was a maid servant monk called Künga Namgyel (kun dga' rnam rgyal) who knew such things as how to sing and dance in the highest of ways. In order to learn, I imitated what he did in that manner, and I [then] passed my time doing such things as dancing, sporting, scattering and casting [as is done in religious ceremonies]. 


\section{Early Non-Sectarian Training: Dechen Chökhor \& Kongpo Nyipuba}

Indeed, [my] head discipline monk [was endowed with] very pure vision, [and] as [we had] a tradition of following lamas without sectarian biases, I was given such things as empowerment by those [lamas from other traditions]. In my spare time, I would listen to religious teachings, and I received a great many longevity benedictions from the reincarnated lama named Master Dechen Chökhor Rinpoche (bde chen chos 'khor gyi yongs 'dzin sprul sku rin po che). I also obtained many longevity benedictions and the empowerments for the Wrathful Dagger (drag po kI la ya) and other teachings. [These facts] are recorded in the hagiography of that lama himself, and he even punished me in a manner appropriate for a child, and acted affectionately [toward me]. Similarly, I remember obtaining some longevity benedictions [from] the incarnate lama named Dradingpoché (grwa sdings po che) and having an audience with the holy objects [of his monastery].

On my way back from the southern Mön region, going to the estate, I especially [remember] meeting Lord Rindzin Kongpo Nyipuba (kong po snyi phu ba rig 'dzin dbang po), the stainless descendent of the treasure revealer Sangyé Lingpa (sangs rgyas gling pa). [T22] Although my own age was minute, I was elated. That lama sustained [the truth of his family's] liberation story with uncontrived ease. I especially remember [how he would] wrathfully [admonish] his attendants with very fierce compassion. I myself, my head discipline monk, and everyone obtained the very expansive and pure longevity benediction and the Guru Drakpo (gu ru drag po) empowerments of Sangyé Lingpa. During the empowerment, the lama [dressed in] white robes wore a ritual headdress [and other ritual regalia]. His hair was pushed down the back with a headdress accompanying 
on top. He was looking south [while] sitting on a throne in a chamber room of Trashi Möngar (bkra shis smon dgar), and I and my discipline monk sat before him. After the empowerment, [he] stood [dressed in sacred regalia] with a 101-beaded glass rosary, and with his own hand, he gave them to me. I remember clearly him saying to me many times, "This is a [connection] so that you accomplish the four wondrous activities." $\mathrm{He}$ even gave me a great many sacrificial pills such as the black medicine of Sangyé Lingpa. Because these Nyingma Lamas are authentic beyond dispute, it was certainly beneficial to meet them.

\section{Yölmopa Initiates the Official Recognition Process}

By that time, the steward Pema had been arranged to be my assistant. In those days, the Yölmopa [Regent] pretended to be sick while residing in a thatched hut in the Crystalline-Pearl Forest. [T23] Accordingly, he sent me the materials required for the recognition [process] (e.g., the small painted scroll of the moon-mandala pure vision and a ceremonial canopy) along with instructions. As he did this, he asserted my recognition publicly and extensively.

My previous [incarnation's] ill-reputed nephew, his shrine room assistant, and [close disciples] arrived for the purpose of testing me. [The thing that] I recognized was there at the top of the row, and I handed over a key for the box. As they examined me, they were even moved to tears because of my confidence. I went through the implements inside [the room] saying what was mine and put a few of the keys that I picked up in their hands.

The treasurer of the previous saint, Lord Kudün Künzang (sku mdun kun bzang) also [became a believer] as follows: Because he wished to [be a part of the] identification 
[process], he was coming to meet [me]. [But], as soon as he arrived inside the door, I said, hitting the mark: "Kudün, I remember someone like you. Have you done something wrong?" Again, they held back their tears and with an intense sigh, I alleviated them.

\section{4 - Year of the Wood-Monkey - Fifth Month - Age 4 The Official Letter of Recognition \& Enthronement Request}

Then, when I was four years old, on the day of the religious festival of the tenth day of the [first or second] month of summer (i.e., the fifth month of the wood-monkey year), [Tenzin Norbu] sent the official letters of recognition along with the enthronement request. The essential meaning of the official letter sent even to my mother and father was: "It is certain an auspicious entrance into a karmic connection [to put forward this fact of] the recognition of the supreme emanation of the victorious Wisdom-Holder on this special religious festival day of Guru Rinpoche. I request that [he] actually be dispatched [to the Dorjé Drak Monastery] in accordance with this [recognition]." And, [Tenzin Norbu] was still thinking at that time that it was unlikely for any type of unforeseen defect, like mental illness, to arise in the person of Padma Trinlé. Or perhaps he was still worried as he thought about the possibility, and thus he also says, "I request that [you] are as careful as possible [regarding the specifics] of raising his form." [T24] [The letter that] said such things as well as some [other] instructions was dispatched by Rinpoche Peldrakpa (rin po che dpal grags pa). There was also a prayer attached [to the letter] for the quick returning of whatever rebirths and even some sentences written by the pervasive lord (rigs kun khyab bdag) that I [understood as] a longevity [liturgy]. [There were] other things such as the fact that he would protect us with love forever. 


\section{The Passing of the Regent Yölmopa \& the Recognition Process}

Prior to that day of the tenth, on the fifth, [we received word that] the supreme bull, that accomplished Wisdom-Holder himself who had [taken care of his trainees] that [were so numerous that they] sprouted like bamboo, had entered and remained in a state of peace. Having kept that [information] a secret temporarily like that, Rinpoche Peldrakpa arrived with an assembly [to give us this news and to test me]. When he delivered the official letter and [other items], I bowed in reverence and said twice: "My Yölmopa emanation has died! No!" Others doubted it and my father [was upset].

They concealed [something in] the padding of a small drum of the previous saint, and they gave it to me. Because I inquired, "The padding of this [instrument] was [here] like this. Where did it go?" Those present there [became] believers, and after they put the padding in my hand, they revered that [musical instrument] with the [spirit] of children, and they sat there playing the instrument without regard for the passing of time.

Having been overcome with unerring faith by [this] small act of recognition [mentioned above], the prophecies [from] various religious protector gods—particularly, the one produced at the Jowo Rinpoche oracle, and the earlier and latter prophecies of Yölmopa, the recognizers returned [to their homes]. [T25] I [then] started learning such things as reading block print intermixed with [behaving] and playing in religious manners as I did before.

\section{5 - Year of the Wood-Bird - Age 5}

\section{Transmissions from Kongnyön Heruka Lhatsün Namkha Jikmé}

Around when I was five years old, an emanation of Vimalamitra, Kongnyön Heruka Lhatsün Namkha Jikmé (kong smyon he ru ka lha btsun nam mkha' 'jigs med) 
was on his way at a prophesized time to open the realms of Bhutan and Sikkim. He stayed in a tent that was pitched on a field in the pleasure gardens of the estate of our neighbor named Dekyi Rapten (bde skyid rab brtan).

At that time, Lord Kongnyön would not come out to the [exit] of his dwelling, and even the elaborate things that he did have, such as his mule, were not great. Thus, when he started out on the path, he probably [packed] the normal accoutrements of a renunciate, such as the Heruka implements and so forth. He had only the few things of a realized one; even his attendants were [limit to] his nephew named Pelri (dpal ri).

To me, my head discipline monk, and everyone, [empowerments for] the Wrathful Guru of the Essence of the Jewels (dkon mchog spyi 'dus gur drag) along with the Lion-Face (seng gdong) Cycles were given extensively in the tent. The master of ceremonies, his nephew Pelri, took care of things. He wore a [special kind of] cotton shawl of a realized person and a meditation belt. I saw [him] play music with his left hand and hold ritual implements in his right. [He performed] together with two or three drummers and [attendants chanting mantras]. Indeed it was most beautiful and [jolly]. Although the details of the recognition do not occur to me, I obtained a connection with the kama tradition from this great empowerment, and it was thus very good. [T26]

\section{Transmission from Rinpoche Amjak Chakdor Trashi}

Otherwise, although he was a direct student of both the father and the son, Chögyel Wangpö Dé (chos rgyal dbang po'i sde) [i.e., Trashi Topgyel] [and Ngakgi Wangpo], [who were lay practitioners], the one from Kham known as Rinpoche Amjak Chakdor Trashi (rin po che am ljag phyag rdor bkra shis) was a monk of pure vows. He simultaneously maintaining the yoga with signs and without signs and his commitments 
to his two lamas, the father and the son, were unpolluted by even the smallest stain. [Nevertheless], this was the one who had been the master at Ewam Chokgar, but was dismissed by Rindzin Ngakgi Wangpo.

By this time, he was again acting as a lama of the monastic assembly [of Ewam Chokgar], and we invited him to Namsé Ling. Although he was on his way back to the monastic assembly, the precious teacher stayed a few days and acted as a protector (bsrung zlog). Particularly for us at that time, he was a perfect lama from our own tradition [of the Northern Treasures]. As an accomplished master, the Rinpoche himself was an appropriate lama for me.

[We] first requested the one hundred effigy longevity benediction of the Iron-Tree (lcags sdong ma) Cycle [of the Northern Treasure Tradition]. Then, we requested a few more each day. The Life-Vase [artifact] of Maratika (ma ra ti ka), which is one of the Nyang treasures, was essential to his ritual activities. However, Rinpoche was very deficient in self-confidence. Because of his difficulty with the written words, when they came out [of his mouth], his heart was distracted. He ended up touching the brim of the Life-Vase to my forehead very emphatically, and because I was still a child, it made me very upset. Then in accordance with the good traditions associated with drawing forth one's life-force, Lama Draklha and others danced and played music. Distracted, I was happy again. [T27]

Indeed, I had the good fortune to have heard the teaching from this lama in a manner that filled the vase [of my heart] to the brim. It turned out to be a very good thing as there wasn't a more authentic teacher [at the time] within this lineage of higher fathers and sons. Because this Rinpoche did not know the religion of men and was very concerned with women and beer, he pursued unclean enjoyments to the end. His mind 
was probably involuntarily distracted by desire as it was swept [discordantly] by slander [resulting from] his dismissal.

As soon as I settled on my throne, we performed the rites for dismissing him. $\mathrm{He}$ went to live and practice in such places as Lhodrak Kharchu (lho brag mkhar chu) and Tselam Pelri (tshe lam dpal ri). In the end, he passed peacefully in the hidden land of Sikkim. Thus, the intentions of the spiritual friend turned out to be in accordance with the dharma. That I came to be deprived of teachings, such as his rare reading transmissions and empowerments, [resulted from] what appeared as a magical emanation of maliciousness that had settled in his heart.

\section{Mystical Experience near the River}

As I behaved as all children did at that time, I played water sports as I would go into the [river]. While doing that I would investigate the soft surfaces of the river rocks and the hand-span lengthy sharp corners of [other] stones. The shards of rock [caused] a few unclear [arrays] of pictures of the bodily form of Lady of Zahor in Oḍdiyāna (o rgyan za hor ma) inside of the ever so clear halos of light on the surfaces of the soft rocks. [T28] In the cracks in the rocks, it looked like a nine-headed Vishnu that had a raven head and a snake tail below.

I pointed them out to everyone. But they did not believe these words coming from the mouth of a child. While I sat there [looking at it], there were only those who were playing along saying, "There it is! There it is!" But, really there wasn't anyone there who was actually trying to see anything. Nevertheless, I performed my accumulation practice there while holding the uncontrived image of the Lady Oḍdiyāna. Then, I had an artist draw that heavenly body and it was a great likeness. My companions said that it was an 
evil sign [when they saw the drawing]. Someone snatched the image of that heavenly body from me, and I heard that they burned it. One of my companions flung the ashes away outside. Whatever bad thing was to happen, it didn't.

\section{The Birth of the Younger Brother: Penchen Könchok Chödrak}

Indeed, in that year of the Wood-Bird, my brother, Penchen Könchok Chödrak (paN chen dkon mchog chos grags) was newly born. [We] manifested just like the big and small victory banners of the Moon-Mandala vision of the Rindzin Yölmopa. From among the seven siblings that I have, the two of us were as if close in private and later both of us would obtain [renunciation]. And, we would even come to do a few activities for the sake of the teachings of the Victor; these [deeds] were [done openly for all].

\section{6 - Year of the Fire-Dog - Sixth Month Age 6}

\section{Departure \& Enthronement at Dorjé Drak}

Then, in the sixth month of the year of the Fire-Dog when I was six years of age, preparations were under way for my [official] reception at the monastic seat. At that time, the steward who shouldered the responsibility [of the monastic compound] was called Rinpoche Peldrakpa. Generally, as the seasons were changing, a great and continuous effort was being made to prepare [for my departure]. [T29] The lamas and their disciples continuously expressed their thoughts regarding what needed to be done by others around them. Even those [that were not able to do great things] prepared the god-cakes (lha bshos).

When the time came, lamas such as Rinpoche Amjak, Lama Draklha, and Lama Tropuwa (bla ma khro phu ba) together with many other important people arrived to be 
my escorts. On an auspicious day of the sixth month, we ascended from my parent's estate to Luding (klu sdings). Preparations of all kinds had been made, and even my grandfather came along as a caretaker (tshe 'dzin). Eventually, we set off on our journey. At the harbor where we were to continue by boat, the one named Drakdalak Künden (sgrags mda' lags kun ldan), [a future patron], approached and honored me for the first time.

Then, early in the morning of the tenth day, [we arrived] at Dorjé Drak. Monastic groups from home and abroad assembled to form an abundant procession of lamas. The people from the surrounding estates came and there was a fair complete with singing and dancing. Then, I finally arrived in my private chambers for the first time, and I rested for a little while. When I went to the assembly, they were performing the [Guru Rinpoche practices that are celebrated] on the tenth day [of every month]. They stopped when they were bringing down the blessings during the ceremony and [honored me with] a procession of lamas and other activities. Later, when the congregation had settled, they recited the litany of holy names before I settled on top of my throne. Lama Draklha went before me with the burning incense. Just as we arrived at the door, they raised the victory banner of the Buddha's teachings. [T30] Because it was appropriate for [Lama Draklha] to speak, he said, "This has good karmic meaning!" This was but one of the good omens.

Then, I settled on my throne and there were many representatives that were from the primary government to give the tea-session gifts. They were sent to stay in the village. The heads of those groups came one at a time to display presents such as money for my schooling. The assembled people came together after the gifts arrived. We ended with the appropriate liturgies and then enjoyed a religious celebratory banquet. For days I received such things as tribute and feasts, one after another. Then those who were 
dwelling up [the mountain] from the monastic estate were invited for a feast and they convincingly paid their respects and we recorded all of the smallest details.

\section{Journey to Lhasa to be Tonsured by the Fifth Dalai Lama}

Sometime after the enthronement, I set off on a journey for Drepung to offer my hair in tonsure. We set off gradually on the boat for Denbak (dan bag) in secret and went through Trengpo ('phreng po) and Sheldrong (shel grong). Folks were coming from near and far to the great palace of the Potala. When we were on the plains [near there], [the regent] Sönam Chöpel came out by horse to escort me to Drepung. We prepared for his arrival by getting off of our horses giving way [in deference]. Representatives that stayed in the village arrived and prostrated [as he] arrived. His lordship, the regent, was greatly trusted. Then we went to Lhasa with the regent.

As soon as we arrived in Lhasa that night, there was a night watchman from Chongyé ('phyong rgyas) who blocked our way. [T31] The next day I received my instructions to permit me to go to Drepung to offer my tonsure. In accordance with the orders, we got up early the next day and departed. As we went in the direction of the monastic college itself it was as if it were humming with bees with the sound of thousands of dedicated spiritual friends reading, debating, and studying in the great temple of the glorious Drepung; it was like a non-dual example of the pleasure grove [of the time of the Buddha] and the crown jewel of all the monastic assemblies of the Land of the Snow. We rode on our mounts as long as we could. Then, we got off and advanced gradually by foot. Then, we were sent to the dwelling houses near the college of philosophy. 
At that time, I arrived in the presence of the Supreme Lord, Lozang Gyatso (blo bzang rgya mtsho), the incomparable and omniscient protector of both gods and other migratory beings. Soon the interview began. It was the nineteenth day of the sixth month. We performed the supporting ceremonies together with the prostrations. Then I offered my head in tonsure. Then, he gave me the name Lozang Pema Trinlé Tekchok Wang-gi Gyelpo Yong Düdé (blo bzang pad+ma 'phrin las theg mchog dbang gi rgyal po yongs 'du'i sde). Then, he gave my chamber attendant the name Lozang Döndrup (blo bzang don grub). After that, we had lunch in the guest house and the exalted one encouraged us to stay for the morning prayer session. [We went,] and I listened to the recitations. [T32]

Not long after that, he sent word for me to come before him. I went along with my chamber attendant who aided me as a companion. First we did the seven-lined prayer, and when that was finished we did the visualizations from my own tradition. We did the major and the minor lineage supplications together with the fire amendment called the Urgyen Jenjukma (u rgyan rjes 'jug ma). We also did the prayer for Guru Rinpoche and his twenty five disciples, and he issued a reading transmission regarding the stages of practice in [the vehicle of the] mantras. He also gave the ripening empowerment for the Iron-Tree Longevity Benediction. This is how I began to receive his kindness. At that time, he even issued such prayers as The Sun Lord's Transformative Display (sprul pa'i zlos gar bsgyur ba'i nyin byed dbang) from Gyurmé Küntu Zangpo's ('gyur med kun tu bzang po) Expansive Sky (mkha' dbyings). And then he even caused us to be abundant with auspicious gifts of various sorts, such as canopies, fabrics, and horses.

In the vast field of a sublime pleasure grove, Although all my actions were that of a child, indeed the spiritual life [began]. 
The karmic propensities resulting from my training in previous lives were strengthened,

And all at once there was such a display of compassion, teaching, enlightened activity, and accomplishment.

$\mathrm{O}$, spiritual friends who uphold the traditional tenets for yourselves and others, You adhere [to the teachings] well and are pure [toward outward] appearances without biases.

With your great many rivers of powerful blessings,

Let this vessel be filled with the ripening and liberating teachings of wholeness.

The head of the monastic community of Ewam Chokgar, The one who is the supreme Wisdom Holder on the lion throne, [T33] That congregation of vajra holders of many kinds Scattered one hundred times the flowers of auspicious consecration.

In a palace [filled with] both the religious attainment and the happiness of the Ganden monastic college, which was like that of Drepung, I approached the feet of the omniscient Lozang Gyatso, Who was like the regent of the sovereign, Mipam Gön (mi pham mgon).

I came forth from my home and had my hair shaven.

In these days I became a student of the omniscient lama.

He nurtured me with friendly love that was unafraid of anything 
And with religious teachings, such as the empowerment of immortality.

After I offered my hair in tonsure at Drepung, I went to see [the surrounding] religious sites. Then, I circled back to Lhasa. Then, I went to see an aristocratic patron (rgyal po mchod yon) at the estate of Ganden Khangsar (dga' ldan khang gsar). The patron gave us the greatest gifts [for our services]. I then went to visit the temples of Lhasa, such as the Trülpé Tsuklak Khang (sprul pa'i gtsug lag khang) and Ramoché (ra mo che).

\section{Training in Etiquette and Literacy \& the Family of a Young Incarnate Lama}

Not long after that, I received some empowerments at my own abode that initiated the start of my studies of etiquette. Lama Peldrakpa instructed me regarding how I should conduct myself if I were to enter a lower court. Since it would enrich my education, I was instructed regarding how to conduct myself if required to reside in a higher court - that of my superiors from the regent (sde srid sku zhabs) [on down]-regardless of the fact that I was [still] young in those days [and would not require the skills until later in life]. He taught me how it was inappropriate [to be concerned with my petty needs] while receiving instructions from the Supreme Lord [i.e., the Dalai Lama] or before a tantric lama. Such things did not come easy to me. I depended then and in the future upon Lama Peldrakpa for his great understanding of what is helpful and what is harmful.

At some point, I came to revere the mantra holder Ngakwang Püntsok (ngag dbang phun tshogs) as my master of monastic discipline. [T34] It was the beginning of a long [affair] of practicing ethical conduct and rituals that were very important and 
memorizing [a few] shorter blessings and empowerments in accordance with how [this lama] thought about things.

My constant attendants included relatives like my deaf nephew named Namtrül (rnam sprul), Lama Garap (dga' rab), and my [personal] attendant named Pema (pad ma). Once, while they were serving me, we went to an exhibition in the library above the estate house (bla brang). On the back side of an old text [about] the iconography of the Dowang (mdo dbang) cycle, there were words written in an informal script (dbu med) by pen. Because I could read only a few of them, my attendants told me that it had been understood [since the days of old] that if you can read nothing other than what comes to you in printed letters (dbu chen) it would not guide you well. But, as soon as you are able to read semi-formal scripts (shur ma), you will be able to understand and things will be clear. They told me the story of the one named Drigung Peldzin ('bri gung dpal 'dzin) who didn't have any other good qualities except for his singular ability of reading. This is how I became self-conscious about this [skill of] reading from an early are.

Because I was young during those [times], the monastery and Namsé Ling were like the warp and weft of the fabric [of my life]. When I stayed in the monastery, my grandfather was usually in residence [to ease my emotions]. Sometimes, my grandmother was sent as a substitute to stay with me. Once, when I was staying at Namsé Ling, I obtained such things as the longevity benediction when Pönlop Gamnyön Trülku Chakdor Norbu (dpon slob sgam smyon sprul sku phyag rdor nor bu) visited.

There was an iron dagger that had previously been given to me [for protection] by Yölmopa [Tenzin Norbu], which was intended for wrathful exhortations. At that time, my treasurer [named] Kardrakpa (kar grags pa) removed [that iron dagger] from my neck. Having received the news of that theft, I prayed. And as a result of the connection [with 
the object of my prayers], that dagger was after a time returned to my hand. [T35] I [still] have it today.

\section{7 - Year of the Fire-Cow - First Month - Age 7 Karmic Connections with Lord Zurchen Chöying Rangdröl \& Others}

Periodically throughout that year, my teacher over many lifetimes, the great Zurchen Dorjé Chang Chöying Rangdröl, came to visit with me. He gave me extravagant gifts and I requested my initial instructions, [which were tasks like learning] the longevity benediction of the Hri Chikma (hri: gcig ma) cycle of the Zingpa (zings pa) tradition. In the first month of the year of the Fire-Pig when I was seven years of age, I went to Gungtang (gung thang) and requested [initiations] for cycles like the Mahākaruṇā (thugs rje chen po) and the Awareness-Holder (rig 'dzin gdung sgrub) of the Northern Treasure Tradition.

In the third month of that year, I travelled to Namsé Ling together with my monastic assembly. They stayed for one month, but I stayed for a longer time. Lama Chöying Rangdröl had been appointed as the [principal] lama at the Katok Monastery (ka thog) in Kongpo (kong po). So, [I simply worked] on skills like ceremonially scattering flowers, [because my teacher was not in residence].

A lama named Samten (bsam gtan) arrived from Kham (khams), and I gave him extensive gifts [for his services], and he satiated my hopes by meeting with me face-toface and so forth. He performed a few tonsure ceremonies for the nephews of the aristocracy and others and gave them [spiritual] names.

[The lama named] Lhatsün Künzang Namgyel (lha btsun kun bzang rnam rgyal) [came] from the hidden lands of Bhutan and Sikkim. He performed a longevity 
benediction for me as well as for both of my parents. He had some sacred artifacts and treasures in his possession [that he intended to entrust to me]. So, he composed some verses [regarding the trust] and gave them to my monastic assembly before he departed.

\section{8 - Year of the Earth-Mouse - Age 8}

\section{Strengthening the Relationship with Lord Zurchen \& a Death in the Family}

In the year of the Earth-Mouse, when I was eight years of age, the great Zurchen Chöying Rangdröl came from Gungtang to our monastery, and we requested a few empowerments and blessings. In particular, [Chöying Rangdröl] said to me, "I will now open the door of our initial religious connection." [T36] He then gave me the ritual and liturgical instructions for the longevity benediction of the Iron-Tree cycle, and I received them [myself]. Then, he gave me drawings for the emanation body of Iron-Tree and the enjoyment body of Amitāyus (tshe dpag med) and [told me] to think of them as connected [to each other].

One day when the stars were aligned, all the necessary preparations were made in the shrine room of Dorjé Drak. As soon as I had completed the empowerment practice there, I performed the preliminary practices such as the bestowment of the donations for the initiation gift and physical blessing [to be given by] the lord lama. Then, he bestowed the empowerment for the Iron-Tree cycle on a few older monk and my parents who came from Namsé Ling. After that, I performed the reading transmission of The Seven-Line Prayer along with the entire monastic assembly. That was the beginning of the journey [through] the deception of this life.

Later, my lord lama and I travelled as master and disciple to Namsé Ling together. We were on the road when we were entangled by fog and settled to the west of our 
destination. A messenger showed up during the night and told us that my grandmother had a water-borne illness and that she had died that night. Then, the holy lama turned the mouth of his horse [toward his destination], and at about the first crow of the rooster, he arrived at [my family's] estate. He performed such things as the transference of consciousness [rites] and the reminding-instruction [for the recently deceased].

In dependence upon the mandala of the circle of light that is for the benefit of others [who are with] the peaceful and wrathful deities, he compassionately indicated a clear path [for the deceased]. Because of the fruits of the deceased's actions in this life, such as his wholesome disposition and having completed a million recitations of the sixsyllable mantra, she will be born as a boy in the new house of Dekyi (bde skyid), a noble family in service to [the house of] Mönkhar (mon mkhar) itself. As he will be inclined toward discipline and spiritual practice, [he will be known as] the fully ordained monk Tsültrim Lekpa (tshul khrim legs pa). [T37]

[Later,] the holy lama was going to receive the profound teachings of the wondrous variety at the feet of the pervasive lord Kagyurwa (bka' 'gyur ba) at the abbey of Trashi Tsé (bkra shis rtse) in the land of Yarlung (yar klungs). On the way, he came to Namsé Ling. He performed such things as the ceremony of the knife, the exorcism of Pema Lingpa's Wrathful Guru Cycle (pad gling gur drag gi gtor zlog), and the longevity blessings for my monastic proctors. Above my chambers, he extensively bestowed a ripening empowerment for a painted cloth mandala of the Mahākaruṇā of the Northern Treasures (byang gter thugs rje chen po) for me and my mother.

At that time, I stayed at the estate. As it was the twelfth month, which had been determined [through astrology] in the schedule for the Dorjé Drak Monastery and its associated monastic community to perform the extensive effigy exorcism and the 
accompanying dancing ceremony, they completed the preparation of such things as the costumes. It was not, however, a good time for my grandfather [because of the situation regarding the death of my grandmother]; they departed for Namsé Ling. As soon as the party arrived from Dorjé Drak, they performed the purification of obscurations rites for the deceased at the arrival of each weekly interval, such as the ritual from the Mahākaruṇā Cycle, and continuously accumulated hundreds of thousands of repetitions of the longevity spell (tshe gzungs). They stayed there performing such activities for about twenty days.

Then, it was the day of the great monastic gathering to signify the release of the [monastic assembly from] the ritual ceremony of the relics. My own monastic community [gathered together with] the Gelukpa monastic communities of Chongyé Trashi Dechen ('phyong rgyas bkra shis sde chen) and Jing Samten Tsé (bying bsam gtan rtse) to the right and left of the small monastery. I acted as the master of ceremonies over the great monastic gathering and gave the departure blessing. It was the first time that I acted as the master of ceremonies. After that, I stayed at the estate.

\section{Renovations and Consecration at Dorjé Drak}

While my monastic community was on the way to Nyemo (snye mo), [we stopped in] the great assembly hall of Dorjé Drak (rdo rje brag), which had previously been the reception hall for the dignitaries of Trengpo ('phreng po). [T38] Because [the assembly hall] had not been [maintained], our caretaker took on the responsibilities, [and the building was stripped and stained]. There were two tall pillars [reaching up into] the highest part of the ceiling accompanied by twelve varnished pillars all around. In a shrine room, there was a copper and gilded gold statue of Śākyamuni Buddha that was 
constructed by Rindzin Yölmopa for the memorial services of Rindzin Ngakgi Wangpo. To the left and the right of [where the gathering] clouds of monks [would sit], there were statues constructed from molten copper in the form of the eight close disciples of the Buddha, the Supreme Pair of Disciples, and their two wrathful [incarnations].

That year we celebrated the completion [of the additions to the hall]. I performed the consecration rites along with my monastic assembly. At that time, I did little more than sit in the assembly. Because of my ignorance regarding a great number of things such as [the details for this] ritual, I merely scattered the flowers [during the rites]. In observance of the memorial service for my grandmother, newly constructed statues of the eight spirits were made. These were [later] invited from Namsé Ling to my monastery.

After the older monks completed such activities as making the spell-scroll offerings [for inside the statues], the omniscient Zurchen Chöying Rangdröl arrived at Dorjé Drak. On the second day of the preparations of the mandala of the Eight Pronouncements of the Union of the Blissful Ones (bka' brgyad bde gshegs 'dus pa), [the lord] performed the extensive consecration, and now [the statues of] the eight spirits reside in my shrine room.

At that time, the eight-year-old listened to shorter sermons, such as the reading transmission for teachings that passed through Kelden Gyatso (skal ldan rgya mtsho), the ritual arrangements [written by] Rindzin Trinlé Namgyel (rig 'dzin 'phrin las rnam rgyal), and the longevity benediction and the root tantra for the Magical Emanation Cycle (sgyu 'phrul). [T39] 


\section{9 - Year of the Earth-Ox - First Month - Age 9 Empowerments from the Great Fifth Dalai Lama at the Potala}

In the first month of the Earth-Ox year, when I was nine years of age, my parents arrived from Namsé Ling with whatever we needed for a journey. We travelled together and did things such as meeting important folks at their estates, receiving touch-blessings, and visiting the sacred sites of Lhasa. Once they had paid their respects according [to custom], my father and my monastic proctors returned to [Namsé Ling]. I stayed [in Lhasa] after [they departed].

On the twenty first day of the second month, [we] commemorated [the life of] Trashi Topgyel at the Potala, that second harbor [of Avalokiteśvara], in the presence of the Fifth Dalai Lama. In the past, [we] prayed [to the Supreme King of the Victors] expressing how [we] needed a great number of teachings from our own Nyingma tradition, [and he chose this day to fulfill our prayers]. Zhapdrung Rinpoche (zhabs drung rin po che) from Nenying (gnas snying), [several other] venerable [lamas] together with the essential monks of [their] monastic communities, and I [were all there, totaling] about seventy people [in all that were] there to receive teachings.

[We] obtained the great empowerment of the Awareness-Holder (rig 'dzin gdung sgrub) of the Northern Treasure Tradition, using the painted cloth mandala in the "Three Realms" chamber and the extensive empowerment of the heart practice of the Wrathful Body (drag po rtsal) and the related Eight Great Practices (sgrub sde brgyad). We entered into the definitive bliss of a version of the Mañjuśrī Yamāntaka that was a union of the

revealed Gyazhang (rgya zhang) version, which was a resplendent flower like the seal of samsara and nirvana, and the stream of empowerments that came through the Nub 
(gnubs) clan. We also received an extensive transmission of the verbal preliminary teachings (kha bka' ba'i slob ma sta gon) and the empowerments for the Complete Liberation of the Three Realms (khams gsum yongs sgrol), the weapon's rites (zor), stūpa rites (mchod rten), and tantric master rites (rdo rje slob dpon) in accordance with the traditional method of Trashi Topgyel.

During the weapon's empowerment, [he] performed [with] great kindness and very elaborately-he even wore special clothing and things like that. [T40] Because I was [still] young at that time, I did not [yet] possess such things as the [weapons and clothing that are donned by students], and thus Nenying Zhapdrung (gnas snying zhabs drung) assisted [me] during the weapon's empowerment.

Other than that, [the Supreme Lord] even kindly issued the thoroughly complete empowerment and reading transmission for the Prayer that Fulfills all Aspirations Treasure Cycle (bsam pa lhun grub ma'i sgrub skor gu ru yon tan gter mdzod) from the Profound Treasure of the Awareness-Holder (zab gter rig 'dzin yongs 'dus) of the Ngari Panchen (mnga' ris paN chen) [i.e., Pema Wangyel] and the long-life empowerment of the Immortal Vaiśravaṇa ('chi med dpal ster). Six [other] masters and I obtained with delightful friendliness the initiation of the Profound Treasure of Vishnu's Razor (khyab 'jug dug gi spu gri), a closed teaching of great profundity, to form a karmic connection [between us]. The Supreme King of the Victors even kindly issued to us individually the extensive lay vows (yongs rdzogs dge bsnyen), and in the end we [all received] auspicious gifts of various types. As we had become rich with the glory of both religion and [worldly] wealth, we all returned to our own abodes. 
At some point either before or after this, a lama from Kham named Garwang Gyatso (gar dbang rgya mtsho) showed up. I gave him the minor reading transmissions and empowerments that [he] requested. Then he departed for Sikkim.

\section{Karmic Connection with Kagyurwa Jamgön Sönam Chokden}

In the fourth month of the year, I went for a short while to Namsé Ling from the Potala. The Great Pervasive Lord Kagyurwa, named Jamgön Sönam Chokden ('jam mgon bsod nams mchog ldan), together with his monastic assembly, had been invited from Trashi Tsé (bkra shis rtse). [T41] As soon as I meet with this lama, great faith was born [in me for him].

Indeed, the holy lama began by opening the dharma gate with the famous Wish Fulfilling Wheel of White Tara (sgrol dkar yid bzhin 'khor lo) in conjunction with the Six Rays of Light ('od zer drug). [He] kindly bestowed [a large group of] authorization empowerments together with the [100-effigy long life empowerment]. I received through [his] kindness the authorizations (rjes gnang) for the three principle deities of the Sage of Bodhgaya (thub pa rdo rje gdan), the Six Syllable Mantra of the Noble Mahākaruṇā, ('phags pa thugs rje chen po yi ge drug pa), the Hero Mañjuśrī Practice ('jam dpal dpa' bo grub pa), the Two Armed White Sārasvatī (dbyangs can dkar mo phyag gnyis ma), the Amitāyus Practice (tshe dpag med grub rgyal lugs lha gcig bum gcig), the Yidam Deity Practice of Hayagrīva (rta mgrin dpa' bo gcig pa grub rgyal lugs), The Spirit Tamer Vajrapāni Practice (phyag na rdo rje 'byung po 'dul byed), and lastly the one-hundred effigy long-life empowerment in the tradition of the Great Saint of Tangtong Gyelpo (thang stong rgyal po). 
I had an intimate connection with this holy one as a result of meeting with [him many times] starting from when I was young, and I try to emulate him. These days, whenever an undisciplined person but comes around, I think fondly of the compassion of this [lama].

\section{The Patronage Journey to Nyemo}

It was in that year itself that it became apparent that I would be going to Nyemo County together with my monastic assembly. For a week or two before this [journey], I recited tantric prayers, such as the longevity benedictions for the Iron-Tree (lcags sdong ma) and the Enjoyment Body (nang longs spyod rdzogs skur bsgrub pa tshe sgrub longs sku ma) cycles, to dispel the obstacles [that might bring misfortune to my travels]. I also routinely prayed to Guru Rinpoche during each of the six parts of the day as if I were obsessed. At night, [I worked with] a heart-practice text called the Practice of Tantric Activities (thugs sgrub sngags kyi 'phrin las) and performed the appropriate [number] or recitations before my tutelary deities. I also offered treasures to the protector deities. After that, seemingly without a pause, I [did what was needed] to prepare whatever companions I was to have by [reciting] the Heart Sutra and the Blazing Wheel ('khor lo 'bar ba) and even performing general reversals (bzlog) [of obstructing energies]. [T42] We even humbly performed the songs and ritual dances of our tradition.

During the fourth moon of the year, it [came to the time when] we were to depart in the direction of Nyemo county, when a direct disciple of the king in the north [arrived]. [He performed] a treasure [ceremony] (gter g.yog), which [included the] revealed treasures [known as] the Lhang Lhang (lhang lhang) and the Apricot (kham bu). Long ago, [the treasure revealer] named Guru Chöwang (gu ru chos dbang) extracted a treasure 
from [that person's] land. At that time, two Bonpos were called upon to perform services [by] the treasure lord. [The father of my previous incarnation] named [Trashi Topgyel] Wangpö Dé (dbang po'i sde) recognized the rebirths of those Bonpos. The foremost of them is the one that came from their monastery, a grandfatherly man named Pekar Lhejin (pad dkar lhas sbyin). He is seen as the one who opened the gates for the enlightened activity [of the journey]. He was like a messenger on a deliberate mission to call me and the monks [to action]. And so, we departed from the monastery at that auspicious time.

The evening that we arrived in the blissful land of Kyishong (skyid gshongs), my parents arrived to accompany me [for the rest of the journey] as was [previously] arranged. The next day, we [began our] travels together. We got off of our mounts in front of the Gongkar Monastery (gong dkar). After performing prostrations, we stayed in the Gonkar village. Someone came from the upper courtyard of the fortress and met with me. The next day, my parents were escorted beyond [this region of] Gongkar, and they made their return trip [home].

My entourage [took] a boat from Chuwo Mount (chu bo ri), and got off at the monastery called Tropu (khro phu). In those days, [people in my entourage or people we meet] were stricken from time to time with a serious illness of the flesh, but there was no way to hold off death.

Then, we eventually made the customary stop [for a night] in the lower part of the valley. The next day, the highest chieftain of the region met us at the monastery of Nyemo Trashi Ling (snye mo bkra shis gling) with a catered escort. Eventually, we were pleased to arrive at the fortress of Bönra Lhünpo Pembar (bon ra lhun po dpal 'bar), which is where this chieftain resided. [T43] 
I suddenly became exhausted, and we rested there. The chieftain paid me a great honor by happily going [to travel with] all of the masters and disciples that followed behind me [as we travelled].

It was [necessary] for us to procure what we needed for up to a month [of living there]. We [achieved this] primarily by constructing an elaborate colored-sand mandala of the Awareness-Holder (rig 'dzin gdung sgrub) cycle for use in the consecration of statues of the Eight Spirits (mtshan brgyad), which was a support of faith that was constructed by the chieftain himself. All together, we performed the two-day version of the consecration including the preliminaries and the actual ceremony.

I did not perform the recitations and so forth perfectly. [When] the text said, "Refrain from engaging in the activities of the mandala," I [mistakenly] applied the white pigment. As I stated above, I [did not perform] the detailed activities of the longevity recitations or the wrathful recitations [properly]. [Despite] performing the beginning of the consecration carelessly, the lay patron's true faith was not impeded.

In a similar [ceremony], the vajra master inside of the practice hall performed the seven-day effigy exorcism of the Lord of Life (tshe bdag) cycle as a service for the chieftain. Meanwhile, I was outside [of that hall] where the mantra holder named Ngakpün (sngags 'chang ngag phun) was performing the weapon casting [rites]. I bestowed the longevity benediction of the Iron-Tree (lcags sdong ma) cycle ten times every day for the chieftain, his parents, and his two daughters. From [the activities] of those days, I amassed one hundred [recitations].

At that time, that chieftain was strong as a result of the power of his faith. Because I was young [the following activities were performed to foster] the knowledge and experience of my monks. [The chieftain] commissioned an extensive feast ceremony 
and a worship service for all [manner of things] like the calendric effigy rites (dus gtor) [for] the commemoration of the previous masters, the three juniper offerings, and the [eleventh-hour] effigy rites during the waxing moon. [T44] It was customary for me to go to the gatherings for all of the calendric effigy rites, not simply for the [rites marking] the eight stages of life and regular gatherings.

One day during a juniper burning ceremony, I arranged a ceramic chalice on the table before my throne. I was to set the example at the front [of the assembly]. I hesitated because the chalice began to tremble, then all at once it fell to a hard surface with a clink. Because the chieftain was very close to me, he jumped up and looked [to see what had happened]. Although the whiteness of the ceramic chalice had faded, it had not even cracked in the slightest bit. As soon as he got up, with his hair streaming down behind him to the earth, he prostrated to me. He picked up the ceramic chalice with his left hand and clinked it with his right index finger. He showed the monks [that the chalice was not broken], and told them that it was a sign of [the my] attainment. Although in my [heart] there was the desire for some sort of sign of attainment, I understood it as luck as well as an indication of the purity of his commitment [to me].

Long ago, both of the [Ngari] brothers ${ }^{224}$ visited this land of Nyemo. In particular, Rindzin [Lekden Dorjé] resided at Delek Ling (bde legs gling) for a long time. His son

224 The Ngari brothers are the Ngari Panchen Lama, also known as Pema Wangyel, and Lekden Dorjé, one of Pema Trinlé's previous incarnations. 
named Pema Chögyel (pad ma chos rgyal) ${ }^{225}$ was even born in Nyemo itself and resided there for a long time. Similarly, [my previous incarnation] and his father named Chögyel Wangpö Dé (chos rgyal dbang po'i sde), [i.e., Trashi Topgyel], came here again and again. As a result of their visits, the land absorbed their blessings and compassion, and it was my experience that up until now, [this is why this region] is so greatly venerated.

At that time, even the lama from Draklha (brag lha) came to recognize me [as a reincarnation of those masters]. By day, the [visitors] formed separate rows [before me]. During the banquet for a feasting ceremony and the like, Lama Peldrakpa (dpal grags pa) and [the another lama from Draklha] would speak to those [gathered] in the form of narrative discourses. [T45] Now and again, people would pay their respects and give us sublime gifts that were required [for our journey]. And thus a month passed while we were at the Bongra (bong ra) fortress. I enjoyed the possessions that I obtained at the fortress in Nyemo for some time.

Until then, the chieftain from Nyemo would summon us together with our monks to my parent's estate Mönkhar (smon mkhar), because I was so young. I would stay for two or three days. There were great gifts, like special vajras and bells. I even performed some blessings. Similarly, I would go to Dokhar (mdo mkhar) to give some blessings. Along the way, I [would act] as a religious painter and a master of blessings and the like. I was also called for day trips to the estate called Luding (klu sding) that belonged to

225 This appears to be TBRC (P2657). 
Zhapdrung Jetsün Drung (zhabs drung rje btsun drung). I would go and say whatever was appropriate to the station [of those in need of my services].

Then, when it came close to the time to return, the chieftain again came [with us] from the monastery to Trashi Ling (bkra shis gling) with a catered escort. The chieftain was old, and [in times like these] he would give me a lot of advice. [On this occasion], I could see that he was crying while he prayed, and I burst into tears. Because of that moment of intimate connection, [I knew that we] would not meet [again].

We came out again on the high road, gradually stopping at places like Yölchö (yol chos) and Trüpu (khrus phu) along the way. Since coming out [onto the high road], I had fallen ill. Having become very sick at Trüpu, I sent my monks out ahead of me. I needed to stay behind. In the meantime, the lamas at Trüpu attended me and offered me entertainments such as sacred dancing. [T46] Their monastic dean was the old abbot who now lived in the pleasure groves [around the monastery]. He even performed a cleansing ablution for me. Gradually, my constitution improved [and I departed] by boat. I met my elder sister at the harbor.

That night we arrived in Jangtang (byang thang). Although there was an expansive skyline, [it seemed for some reason] to be obscured. Then, I and scant few monks followed along the south bank of the Tsangpo River. We went to my parent's estate at Namsé Ling without delay. The young and the old came back to the monastery. I went to Namsé Ling and right away my mother asked about my illness [as it seemed to have gotten a little worse]. My monks stayed for around twenty days, but I stayed a while longer. That was when the great Jamgön Kagyurwa ('jam mgon bka' 'gyur ba) was invited from Trashi Tsé (bkra shis rtse) to my parents' estate, Namsé Ling, and I got to meet him 
[personally]. I requested a longevity benediction and other rites. From there, I returned [to Dorjé Drak].

\section{0 - Year of the Iron-Tiger - Third Month - Age 10 Receiving Transmission from the Fifth Dalai Lama in Lhasa}

In the third month of the year of the Iron-Tiger (i.e., when I was ten years old), I went to Drepung, I and served at the feet of the Supreme Lord (i.e., The Great Fifth Dalai Lama). The Supreme Lord himself taught the cycle containing the root text of the Red Wrath of Nyang (nyang gi drag dmar) and the Yama ('chi bdag) repulsions of the Northern Treasure tradition together with their ritual arrangement manuals. He issued several reading transmissions for a few treasure cycles of other traditions, [such as] the Victorious Warriors of Yama ('chi bdag g.yul las rgyal ba'i ru mtshon), as well as the history of the Northern Treasures. I was particularly flattered [that he] kindly bestowed, for example, an auxiliary text for the Zangtel of the Great Perfection (rdzogs chen zang thal), which is famed as a Guru Practice (bla sgrub) for the worthy. It is a text that is possessed by only a single line of lamas and descends linearly through the likes of Rindzin Ngakgi Wangpo, Rindzin Yölmopa, and the Lords Zurchen [Chöying Rangdröl]. [T47]

\section{Training \& Episodes with Lord Zurchen}

On the road back [from Drepung], [I stopped and] served the lotus feet of Zurchen Dorjé Chang for a long time in Gungtang. [From him] I obtained many [teachings] such as the reading transmissions for Northern Treasure Tradition's Wrathful Deity (thugs sgrub drag po rtsal thems can thems med), the Three Daggers (phur pa lugs gsum), the 
Iron Scorpion (tshe bdag lcags sdig lcags 'dra), the Right of Use Cycle (spyod dbang skor), and the Profound Intention of the Drigung ('bri gung dgongs pa yang zab). I obtained the reading transmission for the Practice of the Emanation Body of Guru Rinpoche (sku gsum rigs 'dus) and the reading transmissions and empowerments for the Vajrapāṇi Practice (phyag rdor dregs 'dul), the Karma Guru (kar+ma gu ru), and the Dzamar (dzam dmar) for monks. [I also] obtained the authorization for the Dzamar Longevity Blessing (dzam dmar srog sgrub) of the Sakya Lineage and the practice for the Goddess of Tinu (lha mo ti nu).

Once while in Gungtang, I was on a pilgrimage to Tsel (tshal). I indeed meet with Zhapdrung Chenga Kelden Gyatso (zhub drung spyan snga skal ldan rgya mtsho) from Yangön (yang dgon) and even received a detailed guided pilgrimage tour. I went as a [ritual] attendant to Garpu (gar phu) Monastery, near the foot of [the sacred] mountain of Yerpa (yer pa). [The Zurchen Lord] extensively gave the great empowerment of Karma Lingpa's Self-liberated Intention of the Peaceful and Wrathful Ones (zhi khro dgongs pa rang grol gyi sgrub) together with the minor empowerments for about eighteen days. On the last day of the empowerment, a very large bazaar gathered. The Zurchen Lord wore the empowerment garments, such as the ceremonial hat. I wore a heavy snow hat, and [the Zurchen Lord] requested that his ritual attendant(s) (i.e., me) bestow the effigy empowerment (gtor dbang reg pa don ldan). At that time, he gave a mere outline of the reading transmission for the cycle's generation and completion stage as [appropriate] for market-gathering religion.

After [he] went back, he kindly continued from the throne room with some of the subtle points about such things as the lower gate and the elaborations of the reading transmissions. [T48] At that time, the personal secretary of the Supreme Lord, which was 
his uncle from Chölung (chos lung), was made sick by the under-spirits ('og gdon; i.e., klu) and [thus] came to Gungtang (gung thang). The appropriate person who possessed great loyalty and faith in their own tradition and was also honest and well educated was arranged [as a healer]. On a special religious day I studied handwriting with my alphabet learning book at the feet of my lama, and the tantric master Ngak Pünpa (ngag phun pa) [monitored my progress].

\section{Training with Jamgön Kagyurwa and Lord Zurchen}

Indeed, at that time the great Jamgön Kagyurwa came to Gungtang. It was arranged so that I went as the Zurchen Lord's ritual assistant to the eastern chamber. For the benefit of Lord Kagyurwa, several tradition's cycles were requested, such as many Nyingma cycles including the reading transmissions for the Red Wrath of Nyang (nyang gi drag dmar), the Ultra Secret Dākiṇī (mkha' 'gro gsang rdzogs), and the SelfManifesting Eight Pronouncements (bka' brgyad rang shar). The practice authorization for the Lord of the Charnel Grounds (dur khrod bdag po) and the reading transmission for the hagiography of Jamyang Khyentsé ('jam dbyangs mkhyen brtse) were also requested. In the afternoon, I requested teachings from the Zurchen Lord [as he was] upon his chamber throne and received extensive obtainments.

\section{Missed Connections with Great Teachers}

By that time, the third incarnation of Pema Lingpa (pad gling), the speech emanation named Lord Tsültrim Dorjé (rje tshul khrims rdo rje), came to Gungtang, and the requested group audience was arranged. This great birth was very learned in the sciences of both sutra and mantra and was an indisputable emanation. Although he was of 
a very suitable quality to be an auspicious lama, I was young and proceeding as a dependent. Thus, I did not have the fortune of receiving teachings [from him]. [Lord Tsültrim Dorjé] had a profound patron-priest relationship with Namsé Ling. [T49] He came again and again giving abundantly such things as the Great Longevity Practice of the Garland of Vajras (tshe sgrub rdor phreng gi sgrub chen). Although, I could not arrange the time to be there [because I was a minor], I still had great faith, [which he knew] through [his] pure vision, and I even received in detail such things as a longevity prayer and letters. Later, in fulfillment of a request made by me, he even sent me a manuscript of the Nectar-Elixir Practice (bdud rtsi sman sgrub) [for making medicine pellets].

Rindzin Trinlé Lhündrup ('phrin las lhun grub) himself came to Dorjé Drak again and again on his way from Dargyé Chöding (dar rgyas chos sdings) to Gungtang. Although it was mutually very auspicious that, for example, I offered him the Karma Guru (kar+ma gu ru) empowerment, I was dependent as mentioned above and hadn't the occasion to request teachings [from him]. This lama was greatly educated and had a particularly wide scope [of understanding] for the Nyingma Kama and Terma (rnying ma bka' gter). He was be-seated in many lineages [and held] the empowerments, reading transmissions, and guidance teachings for each, and I was greatly devoted [to him].

Lhatsün Namkha Jikmé made a point of coming to Dorjé Drak on his way back from Sikkim to Lhasa. When [the monastic community] performed the longevity prayer as a group for my benefit, [he was inspired] to establish for group recitation writings that said such things as: "[He] is like the union of cyclic existence and transcendence in the pure sky." [We] went together as a group to the ritual of the Self-Manifesting Eight 
Pronouncements (bka' brgyad rang shar), the offering in commemoration of Chögyel Wangpö Dé.

\section{Receiving a Student}

My own teacher's young nephew was dispatched to Dorjé Drak in accordance with the entrance rules of [our] monastic community. I tonsured [him] and named [him] Pema Püntsok Wangi Gyelpo Tenpé Nyima (pad+ma phun tshogs dbang gi rgyal po bstan pa'i nyi ma). [T50] This novice [eventually] did the monastic studies of the Illumination of the Secret (gsang 'grel mun sel) and the three-year retreat. These days he resides in Dartsé Dogar (dar rtse mdo sgar) as the [principle] lama. At that time [when he first arrived], we had detailed conversations in my chambers and I offered him an audience with the religious items [in our possession], and he made requests of me.

\section{Lord Kongnyön and the Audience with the Artifacts}

I was granted an audience with a special medical object (hrum sgrub gnam lcags thog mda'), which was invited [to our monastery] from the treasure mountains of Sikkim along with the Crown Jewel of the Naga (nor bu klu'i gtsug tor). I was told many stories [about the objects]. Although I was not to take any of them, I touched them to the crown of my head and prayed. [While doing that], I caught sight of all these red [relic] balls about the size of mustard seeds, [and they] fell into my lap. Lord Kongnyön (kong smyon rje) saw this and I was told that it was an auspicious sign and to put them in a safe place.

At this time, [someone said], "The section regarding root doctrine holders in Rindzin Sokdrup (rig 'dzin srog sgrub) [says], 'Following that [is] the emanation of the wrathful Mañjuśrī-Yama ('jam dpal gshin rje)."' The one who said that recognized me [as 
that emanation]. [He] recognized my father saying, "[His father's name is] Püntsok Norbu (phun tshogs nor bu) and [he is] from the South." [He] recognized my mother saying:

In the southern direction from glorious Samyé, The Radiant Tara (sgrol ma'i 'od zer) [is in] a female body. [Her] beautiful and graceful face is ornamented with freckles.

[When he] meets this [woman], the nature will be liberated (i.e., the emanation will be born).

For many reasons such as those, he intended for me to become a student of his in the flesh, though this never happens. Although he sent the preparations for such a relationship, I was still a child needing his mother and I remained excluded from the freedoms of independence as expressed above. Therefore, he sent [word] to Zurchen Dorjé Chang (zur chen rdo rje 'chang) in detail regarding how I would act as the doctrine holder each time that a teaching of the Rindzin Sokdrup (rig 'dzin srog sgrub) cycle was opened in Gungtang and how I would ultimately need [full responsibility] passed into my hands. [T51] And thus I was to eventually obtain the extensive ripening of the triad consisting of the empowerment, the textual guidance, and the textual transmission. And, still these days, you could say that I practice and teach it myself.

\section{Lamenting Missed Opportunities}

Although I would eventually become scripturally endowed with respect to both the Kama and Terma Lineages, at that time I intended to obtain teachings that I wanted to request from the triad of Lord Sungtrül (rje gsung sprul), Kongnyön (kong smyon), and Dardingpa (dar sdings pa), but I had not become so fortunately endowed with merit. 
But that is not all, when [we] received the news that the Fifth Dalai Lama was going to give the Dorjé Trengwa (rdo rje phreng ba) empowerment at Drepung Monastery, my parents [thought] that it would be appropriate for me to [attend] because the initiation for the Dorjé Trengwa empowerment is important, the one giving the empowerment is unparalleled, and indeed lamas of all tenet systems would gather [there]. [So, they were] insistent [about] sending me. [But], Nganchang Ngakpün (sngags 'chang ngag phun) decided that there was no necessity for the Dorjé Trengwa empowerment for the [adherents] of the Order of the Ancients. My caretakers thought of the costs [of going] and upheld [the decision]. Because they were cut off [from their] good senses, I went home and until this day I have not obtained the Dorjé Trengwa empowerment.

Therefore, although [there is] little purpose in setting forth such things in writing, [I will express the following] in a worldly proverb: Do not be like me! Follow your [own] example! You lineages that give names to lamas and emanations, don't be so selfcentered and gluttonous! As you have given many empowerments to your evil friends, I pray from the [bottom of] my heart that they are made to meet whatever type of religion they requested. [T52]

\section{Poetic Anti-Sectarian Lament}

The supreme lineage of sectarianism [is like a stubborn] rock, As the mountain of conceitedness and arrogance has not fallen, [They] will not meet with the treasure trove of ambrosia, the holy teachings. Listen, thus, to [this] teaching and follow lamas without sectarian biases. 
Because in Tibet there is no doctrine of [non-Buddhists],

All upholders of tenet systems [are] indeed [upholders of] Buddhist doctrine.

Instead, [we have split into] factions of "us" and "them" [merely] based on [our] passions and aggressions.

[Because of this] bad karma, future generations will not accumulate the teachings.

Each of the holy teachings has its own fruit.

Thus, listen to the nine profundities [with] full belief.

Practicing [like this will lead you to] understand all of the key points without biases.

May you enter the teachings completely, [my] followers!

And such [is my] advice [on the subject]. 


\section{Appendix II: The Transliteration}

\section{Introduction}

The transliteration that follows has been generated using photocopies of two different manuscripts of the autobiography of Pema Trinlé. The differences between the two manuscripts are relatively minor and are largely limited to the addition or omission of prefixes and suffixes. The manuscripts are similar, however, in that they are both written in unheaded letters (dbu med), frequently employ short-hand contractions (bskungs yig), sporadically illegible, and generally appear to be unedited. Fortunately, it is rare that any corresponding pair of pages from the two manuscripts suffer from these difficulties at the same moment. If, therefore, there is a smudge or an unfathomable contraction in the first manuscript, the second might clearly display the same section without using contractions.

The transliteration that follows is primarily based upon the manuscript that was scanned in New York in 2003 by the Tibetan Buddhist Resource Center and cataloged as work number W23811. The page numbers that correspond to the hand written numbers in the margins of that manuscript are recorded in the transliteration with the prefix letter of $\mathrm{T}$ (e.g., $\mathrm{T} 1$ or T89). The transliteration is augmented by alternate readings from the second manuscript that was scanned in New Delhi at an undisclosed time on behalf of the Tibetan Buddhist Resource Center and is cataloged as work number W00KG02749. The page numbers that are printed on this text are represented with the prefix letter of B (e.g., $\mathrm{B} 1 \mathrm{~A}$ or $\mathrm{B} 13 \mathrm{~B})$. 


\section{Transliteration}

skye yul dbus gtsang gi ljongs las g.yon tu'i cha bod kyi rdo rje gdan bsam yas mi 'gyur lhun gyis grub pa'i gtsug lag khang chen po dang /_g.yon tu khra 'brug sogs dang nye ba'i sa chu klung ro hi ta dal gyi 'bab pa'i klung ngogs lho phyogs kyi rgyud mon mkhar zhes bya ba sngon chos rgyal gyi gdung 'khyar rgyal po khyi kha ra thod mon du spyugs pa slar phyogs 'dir bsdad pa las de ltar grags so/_zhes t6 kyang gleng la/_gang yang yul gyi dge mtshan phun sum tshogs pa skyed mos tshal dang shing ljon pa'i phreng ba dang/_bza' shing gi ra ba du mas khor yug tu bres ba/_sman ljongs dang/_rdzing bu dang/_mtshe'u dang/_bru'i zhing dang/_grong rdal gyi tshom bur bkod pa/_skye bo dang mi mang pos gang zhing khu byug dang/_ngang pa dang/_ka lan ta ka sogs snyan pa'i sgra 'byin pa/_ri brag dang spang ljongs las lhung sgra 'byin pa'i chu klung dang bar 'bab pa zhig go/_yul de'i dbus na rnam sras gling du grags pa'i khang bzang gi gzhi rta babs dang skar khung dang ba gam mthon po can ra ba dkar pos bskor ba/_skyes chen du mas shis brjod kyi me tog lan brgyar gtor ba'i dge b7 mtshan dang ldan pa na/_rigs ni lha rigs su gtogs pa tsam dang /_rus ni chos rgyal bya pa'i rigs las pha karma phun tshogs dbang po dang/_cho 'brang ni 'brug smyon kun legs kyi dbon rigs las ma rig 'dzin bu khrid dbang mor grags pa ste phal cher ris med pa'i grub mtha' kun la gus shing dge phyogs la gtong ba dang dad pa phun sum tshogs pa shas che la/_'ga' zhig ni rang rang gi sngon gyi byed pa rgyu mthun gyi 'bras bu gtso che bar zad do/_ thog ma'i tshul gyi gleng gzhi ni/_de yang rig 'dzin ngag gi dbang po nyid sa yos zla ba gnyis pa'i tshes bcu gcig la zhing gzhan du gshegs pa'i tshe thub bstan rdo rje brag gyi rgyal tshab tu grub pa'i 'khor los sgyur ba rig t7 'dzin yol mo pa chen po seng ge'i khrid bzhugs bzhin pa las/_ lo de'i mgo zla ba'i tshes gcig la dag pa'i snang bar bla ma dam pa de nyid kyi gzigs snang shar 
tshul rig 'dzin yol mo pa nyid kyi gsung las 'di ltar/_'gro 'dul gzugs sku'i nyi ma ni/ b8 re zhig chos sku'i mkhar nub kyang/_thugs rje'i cha shas yongs rdzogs zla/_'gro sems dag pa'i phyogs su snang/_ de yang mgo zla'i tshe gcig gi nub mo rmi lam gyi snang ba la/_lung pa rgyab lhor bsdad pa mdo byang du bsdan pa chu chen po shar du 'bab pa/_thang bye ma dang ne'u sing ci rigs par ling nge ba/_g.yas phyogs na brag dmar po gnam du zing nge ba la dgon pa yod pa/_g.yon phyogs gzhol ba/_ri thang mtshams na smyig ma'i tshal shin tu ring bas bar snang gi tshad 'jal ba lta bu/_chu phran bu mo rol pa'i 'jo sgeg dang bcas te rnal 'byor pa'i mdun par dba' rlabs kyi gdu bu 'khrol ba'i sgra dang bcas te 'khyog por rgyu bas yid dga' bar byed pa'i sa phyogs de 'dra ba zhig tu sleb/_ nam mkha'i khams thams cad dkar por gyur pa'i 'od chen po 'dug pa la ci snyam du bltas pas gnam gyi gung shar du nye tsam na zla ba'i dkyil 'khor rdzing bu 'bring tshad tsam 'od lnga'i mu khyud rim pa gnyis kyis bskor ba 'dug_g.yas phyogs nas tshon lnga'i ka ba gzhu 'dom nang du bkug pa'i dbyibs can gyi rtse mo zla ba'i mu khyud phyi ma b9 dang t8 rtsa ba bdag gi mdun thad du zug pa zhig 'dug_ g.yon na 'od kyi rgyal mtshan chen po sngon po cung zad mtho ba zhig dang dmar po dma' ba zhig 'dug_ gnyis ka la tshon lnga'i sham bu gong 'og gnyis gnyis 'dug_bdag gi bsam pa la 'i 'di lta bu sngar ma mthong ba'i dge mtshan du 'dug_da zla ba'i dkyil 'khor ya gi na bdag gi bla ma bzhugs yod la che snyam du bltas pas/_skya 'od chen pos blta mi bzod pa lta bu 'dug_da dung nan gyis bltas pas snag tsha shin tu sla zhing pir rtse cher phra bas bris pa 'dra ba'i yul bkod 'jam zhing yangs nyams che ba la khang pa rgya nag gi thog phubs phub yod pa cho le ba 'dug_dbus kyi shar ngos su nye tsam na bdag gi bla ma rig 'dzin ngag gi dbang po de nyid gangs zhu snam sbyar zab ber gsol ba/_phyag na gser gyi rdo rje dang ma hA gu ru sku gsum rigs 'dus kyi tshe bum bsnams pa/_zla ba'i skya 'od dang 'dres pas sku mdog na bza'i tshos 
mdog sogs kyang bab thob bzhin la skya shas che bar 'dug pa b10 mjal/_bdag sogs gyi nar bor ba'i mya ngan chen po bzod du med pa dang/_yang mjal rgyu yod pa'i dga' spro gnyis gcig la gcig 'dran pa lta bu'i ngang nas har gyi langs te lag thal mo sbyar bas btud do/_rig 'dzin ngag gi dbang po thugs rjes gzigs shig/_ces gdung shugs drag pos nga ro 'byin pa'i ngang du gnyid kyis log pa de las sad do/_ bla ma'i mos gus dri med mkha' t9 mdzes par/_thugs rje zla ba'i me long yangs pa'i nang/_slar yang mjal thob snyam ba 'di lta bu'i/_rten 'brel dngos su grub na ci ma rung/_yol mo sprul sku'i dag snang he/_chang 'thungs dga' mar rnam rol yang/_dad pa yod na 'di bzhin 'ong/_thugs rje med pa'i bla ma la/_gsol ba btab kyang ci yong ngas/_zhes pa phyag bris su rtsal ba'i mod la/_de dang cha 'dra ba'i yul zhig tu rig 'dzin bla ma de nyid skye ba bzhes par dgongs te zla ba de'i tshes bcu bdun gyi tho rengs kyi cha la rig 'dzin rgyal ba'i sku skye myur 'byon gyi gsol 'debs zla tshes gsar pa'i cod pan zhes pa bka' rtsom du mdzad pa ni/_rigs b11 kun khyab bdag 'gro 'dul sprul pa'i gar/_zhi dang khro chags cir yang bsgyur mdzad la/_mnga' bsnyes khyod ni bla mar rnam sprul tshe/_ngag gi dbang po'i dbyangs kyis bsnyad der 'dud/_rtag par 'gro sems kho na'i rjes 'gro ba'i/_tshad med thugs rje'i gzugs can bzhin gyur pa/_mgon med 'gro ba'i skyabs mgon khyod lta bus/_bdag sogs gyi nar bor 'di ci zhig lags/_skye rga na 'chi'i chu bo las brgal yang /_khyod ni 'jig rten rjes 'jug thabs tshul gyis/_jig rten bya ba ci yang ston mjal na/_skye ba'i snang tshul gung zhig rig 'dzin rje/_mi bzod khong yus gdung ba'i dbyangs rtsub mo/_sgra snyan rol mor 'os min de lta t10 na'ang/_nyer zhi'i dbyings su mnal mthong gzugs kyi skur/_bzhengs zhes bdag cag 'bad pas gsol ba bdebs/_rgyal ba kun gyi yab gcig gdod ma'i mgon/_deng 'dir rgyal ba'i sras su rnam sprul te/_gdul dka' snyigs ma'i 'gro tshogs 'dul ba dang /_theg mchog bstan pa rgyas pa'i bka' drin rtsol/_ chos dbyings mkha' la gzugs sku'i zla tshes gsar/_dus las mi yol myur ba nyid 
shar te/_chos dkar snang ba 'grem la gegs med par/_'gro 'di'i yid mun sol zhig thugs rje can/_rgyal ba'i myu gu bskrun pa'i legs byas zhing/_smon lam dag pa'i brlan ldan yab dang yum/_ring por spyod pa'i phyogs min pa dag la/_rjes dgongs sprul pa'i snang ba myur du rtsol/_khyim bcas brgya phrag mtshan dpe'i dkyil 'khor ni/_mdzes sdug lang tshos yid 'bri sprul sku'i zhal/_mngon gyur dga' spro'i tshor ba rnyed de srid/_'dus tshogs bar gcod g.yul las rgyal gyur cig_rdo rje bdud 'joms rgod kyi ldem phru can/_legs ldan rdo rje mgon khyod rim brgyud kyi/_rjes zhugs thos bsam sgom sgrub gsol 'debs rgyun/_mi nyams gong du 'phel bar byin gyis rlabs/_grangs med skye bar rjes 'brel yongs 'dzin gyi/_thugs rje myur bskul gsol 'debs bden pa'i tshig_rig sngags 'chang ba shAkya bzang po yis/_thugs bskyed bden pas t11 ji bzhin 'grub gyur cig_ces yang 'di lta bu zhig byed bsams kyang ma khom par re zhig lus shing/_de mtshams rig 'dzin bstan pa'i nyi ma/_rin po che kar grags pa/_dpal 'byor grags pa'i dbyangs/_rin po che brag lha phu ba sogs don du gnyer ba'i mched grogs mang pos bskul zhing/_rig 'dzin rgyal bas brda thabs kyis lung bstan mtshon pa'i rmi lam zhig byung ba dang/_snga khyad che bar yang shes nas bka' 'bangs su spyod pa yol mo sku skyes bla ma'i gzims spyil du tshes bcu bdun gyi nam gyi cha smad dam tho rengs bris pa lags/_zhes ba'i tshigs bcad 'di nyid tshogs 'don du'ang 'dzugs par mdzad pa las phyi ma rig 'dzin yol mo pa nyid rang gis tshig phrad rnams brtan bzhugs su 'don bzhin pa 'di 'o/_de ltar dag snang zla dkyil ma de bzhin byung ba'i bsdus don nyid kyis mdzad pa'i rig 'dzin ngag gi dbang po'i rnam thar gsol 'debs rnam grol chos dbyings mar/_mos dge dag pa'i snang ba rab 'byams mkhar/_tshon lnga nyis rim 'od kyi mu khyud nang/_zla rgyas dkyil 'khor shin tu rgya che'i dbus/_nyid zhal gsal bar bstan der gsol ba 'debs/_zhes kyang gsungs so/_de lta bu'i dag snang gi tshul shog khrar bkod de rig 'dzin yab sras gnyis ka'i dngos slob kho bo'i bla ma zur chen rdo rje 
'chang de nyid la thang kar phyag bris t12 gnang dgos pa'i bslab ston mdzad par rten/_bla ma des kyang thang chung zhig bri bar mdzad de de rnams kyi tshul la thugs kyis dpyad pas rig 'dzin ngag gi dbang po'i sku skye myur du 'byon par dgongs kyang/_zla ba'i dkyil 'khor gyi mu khyud kyi g.yas phyogs nas 'ja' tshon sna lnga gzhu ldar gug pa'i sne rig 'dzin yol mo pa'i sku mdun du zug pa de la/_rig 'dzin yol mo pa nyid kyang myur bar gshegs pa'i mtshan mar thugs dogs za ba dang bcas te slar yang dag snang de'i brda don 'grol bar gsol ba 'debs pa rje zur chen gyis zhu 'phrin phul ba ni 'di ltar/_dpyid kyi pho nyas bskul ba'i rdzi char gyis/_ches phra'i pir rtse rdul gyi khur khyer bar/_ri mo'i 'du byed srin bu'i rjes 'gro 'di/_dri bral spyan ras btsa' ba'i yul ma gyur/_lags zhing bkod 'di'i brda don ma khrol na dga' la ngu bro ba zhig 'dug_'on kyang bdag gi go yul du 'gro ba rnams kyi legs byas kyi mthu brtas na rig 'dzin rgyal ba de nyid zla ba'i dkyil 'khor gyi nang nas gdul bya'i zhing khams gar 'dug gzigs pa sa yul 'di ga skor dang cha mtshungs pa e yin snyam/_ rje rgyal tshab mchog gi sku brnyan kun byang chub kyi sems zla ba/_'khyog ldan gdub bu'i sgra bcas kyi nyal 'gro/_rjes chags stong pa nyi ma'i dkyil 'khor gyi nying mtshams su 'od lnga'i gzhu 'di rig 'dzin rgyal ba'i ye shes lnga phung khams kyi yul t13 la 'jug pa/_ zhugs zin sprul pa'i sku dang yab sras zung gis mdo sngags kyi bstan pa rgyas par mdzad pa'i brdar 'od rgyal mtshan che chung du shar ba/_smig ma'i tshal 'di brda' 'grol gyi gsung mgur dang don mthun pa 'khor ba snying po med par gzigs te gnyug ma lhan cig skyes pa'i ye shes la gzhol dgos zhes dben par bskul ba'i brda yin nam snyam pa blo bag dro ba'i go yul dang/_de las log pa ni ngu phro ba zhu mi spobs par go/_gang ltar mkhyen pa gnyis ldan gyis ma gzigs pa dang ma dgongs pa mi mnga' bas brda 'grol zhig mkhyen lags/_ zhes phul ba la brten slar yang rig 'dzin yol mo pas/_dag snang brda 'grol he ru ka'i 'tshams 'gros zhes bya ba 'di rtsal ba/_dad pa'i zhing pa gang gshin sar/_ya 
mtshan sna tshogs 'bras tshal mod/_dngos grub bdog kun 'byung ba'i gzhi/_di yin mos dges snyam par min/_khrul pas 'khrul pa rnam par 'jig_phal cher 'khrul pas 'khrul pa bskyed/_byin rlabs ngo mtshar dam pa'i lam/_de yang 'khrul snang rmi lam nyid/_rig 'dzin rgyal ba'i zhal mthong zla dkyil ma 'di'i brda sprod ji lta ba ni dka' mod/_'on kyang 'di ga tsam zhig e yin snyam du 'dri na/_ham pa cung zad cig bskyed nas brjod par bya 'o zhes dam bcas nas/_skabs don tshigs su bcad pa ni/_ mkhas btsun grub che'i mngon t14 rlom ri bo ni/_mngon par gsal byed rang gis brtsigs pa'i khrir/_rdo rje 'dzin pas zhi dul brtul zhugs kyis/_btud kyang rnam par mi g.yo'i khengs ldan bla/_'ga' zhig mthong thos bdag gi bla ma dran/_spang rtogs mkhyen brtse nus pa'i dpal 'dzin yang/_nga rgyal phrag dog dus ngan skye bo yi/_spyod pas ma reg mchog gi rig 'dzin khyod/_re zhig dngos su mjal ba'i skal med kyang/_bai dhur sa gzhir bde sogs bdag po yi/_mdzes sdug gzugs kyi skye mched ji lta bar/_nying 'khrul zla ba'i dkyil 'khor dag las mthong/_gzhan yang sman gyi ljongs bzang brag chen dgon/_chu bran 'khyog por 'gro dang smyig tshal thang/_chu chen shar du 'bab sogs ltas mtshar po/_di dag 'di yi brda 'grol e yin bsam/_zla ba zhes grags tshig mthar pho rtags ling/_de bzhin smig ma zhes grags mo rtags kyi/_ming tshig yi ge'i rten 'brel 'di 'dra na/_thabs shes mthon pa zhig ni yin par nges/_zla rgyas nang shar grong khyer nyams dga'i dbyibs/_di rang lha bu zla ba'i grong b17/9b khyer dngos/_ji bzhin mthong ba yin snyam rgya bal dang/_ma hA tsing sogs mtshon snyam blor ma shar/_dkar gsal nam mkha' chos sku mtshan mo'i mgon/_gzha' ris nyis rim dang bcas longs spyod rdzogs/_gsal rdzogs rig 'dzin rgyal ba'i sku'i snang brnyan/_thugs rje sprul t15 sku'i don rtags gsal bar snang/_ri klung dbyibs dang chu bo chu bran gyi/_rgyun 'bab rnam pa mdzes pa 'di lta bu/_sa phyogs 'di ga'i rjes su mthun mdo kyi/_di 'am 'di 'dra'i phyogs su 'byon nam snyam/_dgra 'am rgyal po brtag bya ri dwags kyi/_dga' ma'i myos 
bum rtser 'bab gnag min bcud/_ldugs pa'i snod mang snying por 'phyur 'os pa'i/_snod gtsang yol go ga re des kyang bslu/_thabs shes brda thabs rgyal ba thams cad kyi/_myu gu gang du 'byon pa'i sa bcad gnyis/_rnam par brtag pa khyod dang bdag cag gi/_rjes dpag gcig tu mtshungs 'di ngo mtshar gnas/_gzhu ltar rab 'khyog mchod sbyin brgya pa'i gzhu/_bdag gi mdun par btsugs 'dir mdza' bo khyod/_cung zad dogs mod 'di la bdag cag gis/_brtags b18/10a na gnas skabs mthar thug gnyis shig mchis/_ye shes lnga dngos 'od lnga'i rnam par mtshar/_rdor sems thugs kyi zhags pa'i dper bya ba/_bdag gi thad kar rab zug bdag cag la/_rjes chags gnas skabs 'dir yang skyob pa'i rtags/_ma dag khams sbyangs 'od sku lus 'di yis/_'grub pa'i snang bzhi mtha' ru ngas ma 'khyol/_lta ba'i phub chen gcig gis spang gnyen mtshon/_'bum phrag thub snyems mkha' 'gro'i dbang phyug dang/_nam zhig lji ba'i lus 'di sbrul shun ltar/_t16_'dor tshe 'jigs skrag nyam nga'i snang ba kun/_cung zad shar yang gzhob tu brjis nas su/_pham phaT ha ha hi hi'i dbyangs su rgod/_chos sku'i pha rgan mtshan ma'i dngos yul 'das/_sprul sku'i pha rgan gzhon nu'i skur bstan yang/_longs sku'i pha rgan gar bzhugs zhing de ru/_dogs med 'dren pa'i brda yang 'dra bar snang/_rgyu skar bdag po'i khyim bzhugs pha rgan gyi/_phyag mtshan tshe yi 'brang rgyas 'di nyid dang/_thugs rje'i 'od gtsugs ring por brkyang ba yi/_lam zhugs 'gro ba'i b19 'dun pa ma shar bas/_phral nyid kho bo lnga pa'i lam 'jug pa'i/_brda ston rang ni yin yin ma 'dra bas/_dad ldan khyed 'dra thugs las chung ngu yi/_bde stong ngang ngu dbu mar mnal gzims zhig_ces pa yang rdo rje lta bu'i mos pa thob pas de ring sang gi mi khur ni lug khyu'i nang gi ra rgan dkar por gyur pa rdo rje'i mched slob mi mkhyen dgu mkhyen gyi chos rje rin po che spos dga' nas kyis bskul ba las dag snang brda 'grol du phul ba yin no/_zhes pa rnams phyag bris ngo ma mthong ba ltar 'dir gleng gzhi'i tshul du bris pa lags/_de yang grub pa'i dbang phyug gter bton chen po yol mo pa gsum pa 
sprul sku bstan 'dzin nor bu 'di nyid ni sngon gu ru pad+ma'i zhabs drung du chos blon pad+ma gung btsan du grags pa'i tshe/_rig 'dzin ngag gi dbang po rdo rje bdud 'joms dang t17 de bzhin du skyes rabs kyi phreng ba mang por bla slob tu 'brel zhing /_khyad par sngags 'chang shAkya bzang po dang rig 'dzin legs ldan rdo rje dpon slob tu byung ba'i rten 'brel ltar/_dus der rig 'dzin ngag gi dbang po dang rig 'dzin yol mo pa gnyis dpon slob tu byung ba sogs 'di dag la gter lung gis zin tshul dang so so'i ngo mtshar rnam thar bgrang ba las 'das pa dang /_khyad par rig 'dzin yol mo pa 'di'i grub pa'i rnam thar ngo mtshar ba phyi nang gi rnam thar mang por gsal ba dang /_dus gsum lkog tu ma gyur pa'i ye shes kyi gzigs pa dang ldan phyir 'di skabs kyang kho bo cag rig 'dzin ngag gi dbang po'i yang srid du lung ston par mdzad pa sogs la 'khrul pa ci mnga' yang /_rang ngos nas gzhal tshe 'dang gi bya ba yang mi dran cing sems can 'ching ba kun ldan kho na yin snyam pa la the tshom mi dgos pa kun la gsal bas skyes rabs kyi phreng bar dog 'tshang bgyis kyang gong ma rnams kyi zhabs 'dren par mchis mod/_'on kyang thub bsdan rdo rje brag gi seng khri'i bsrung bya ba dang /_ bstan pa'i rgyun 'dzin par rang nyid la spang rtogs kyi yon tan gyis dben cing zhe 'dod med bzhin du bcing ba dam pos rtag par 'ching ba 'di las dpags na 'phris kyi sa bon cung zhig rang rgyud la btab par gor ma chag go/_de nas slar yang skabs 'dir gong gi b21 yul grong gi bkod pa dag pa'i snang ba la ji ltar shar ba ltar mon mkhar gyi ri t18 lung dgon pa skyed tshal sogs shin tu gsal bar 'grig pa der kho bo la ma'i rum du zhugs so/_ de ltar bdag gi ma rig 'dzin bu khrid dbang mo'i mngal sems can dang ldan par gyur ba'i tshe ma rgan de nyid lha ldan du jo shAkya mjal bar ched kyis byon skabs/_lho brgyud 'bri'u sna'i gru kha nas rdo rje brag gi dgon gnas gzigs ma thag gi rgyu med du nges 'byung skyo shas drag po 'khrungs te spyan chab bsil ba dang skabs 'gar brjod med kyi nyams skyes pa lta bu'i phyi rol gyi kun spyod kyang cha 
ma chor gyur pa zhig byung bar/_phyag phyi rnams kyang yid the tshom du gyur ba byung nges dang /_ma rgan nyid kyis zin bris mdzad par nyams za zi ban bun brjod du med pa'i bde ba 'ba' zhig dang rmi lam yang ngo mtshar ba mang zhing gang gnas par 'ja' zug pa dang 'od kyi gur phub pa sogs byung gsung ba 'dug kyang rang la rgyus med phyin bden rdzun cha ma 'tshal/_mngal na gnas pa'i tshe nang gi sems can de'i sngon gyi rgyu ba las b22 brtsams te ma'i yid la kun rtog gi 'char tshul 'byung ba 'dul lung sogs nas kyang bshad pa ltar ro/_de ltar mngal gyi zla ba grangs tshang nas btsa' ba'i dus la bab pa rab byung bcug gcig pa khyu mchog ste lcags mo sbrul gyi lo dbo zla ba shar ba'i tshes sngon gyi smon lam dang rang cag gi bsod nams kyi mthu las rig 'dzin yol mo pa chen po yang rnam sras gling du e wam lcog sgar gyi 'dus tshogs dang lhan cig par/_stan chags pa dang 'grig pa'i dbo zla'i tshes gnyis kyi nyin dngos chag gi sa skye nad kyis bro 'tshal ba sogs med pa'i bde bar gnas skabs/_nged kyi ma ma rgan mo dbyangs can zer ba zhig yod pa la rig 'dzin yol mo pas sku drung du bos te do nub tsam dpon pa'i sku gzugs sos yong nas che bas sngags mar 'di bzhes pa dang sku srung 'di yang bzhes pa 'gab tshul bcas bla ma rig 'dzin yongs rdzogs kyi las tshogs las byung ba'i mngal sgo bye ba'i ljags mar nya chung gi dbyibs su bgyis pa 'ga' zhig dang /_chos dbang ri'i gter kha bcu gcig pa drag sngags b23 'dus pa'i lcags phur bskur ba mdzad ces thos la/_de'i tshe ma rgan gyi thugs la da lta bro 'tshal ba yang med par blo bur du skye ba ga la gyur snyam ste bla ma la yang sang zad ma gus tsam byung ba la/_de nub skye nad kyis 'phral du gzir te gza' phur bu dang rgyu skar nam gru 'dzom pa'i tshes gsum gyi nyi ma la kho bo skyes pa dang dus mtshungs par gnam lo de'i 'brug skad kyi thog ma shin tu che ba gsum kun gyis thos par byung bas/_rig 'dzin yol mo pa tshes gsum lha bsangs mdzad pa'i lha rgyal dang 'grig lte lha rgyal lan gsum gyis gsung ba sogs byung zer/_de ltar kho bo skyes ma thag de lta'i 
tshul snyan du gsol ba dang ming zhu ba bcas a bar 'phrin las zer ba zhig yod pa rig 'dzin t18 yol mo pa'i zhabs drung du btang bar kha btags kyi sba dar ches bzang ba zhig gnang zhing khyod kyi ming la ci zer gsungs par/_'phrin las zer zhus pas rten 'brel bzang kho bo'i bla ma'i sku skye la 'phrin las chen po yong ba 'dug ces tshogs thog de gar thos sgrags su gsungs/_ming phyag bris su rtsal ba 'di ltar kar+ma tshe b24 dbang phun tshogs/_di bltams su nye ba na gnam lo 'di'i 'brug sgra dang po thengs gsum gyi bar du grags pa sogs dge mtshan la brtags na skyes bu dam pa zhig yin shes che bas gtsang sbra gang che gnang dgos/_zhes pa'i phyag bris dngos ma rtsal ba da lta byin rten du kho bo'i sug na 'chang ngo/_de nas kho bo btsas ma thag par ma bu lhan cig tu tshe dbang dang gu ru drag mthing sogs dbang bka' kha shas rtsal te bla ma dam pa re zhig rang gnas su phebs nas rgyun mi ring ba nas kho bo'i ma la bka' shog phyag bris su rtsal ba ni 'di ltar/_dad ldan rig 'dzin dbang mo la/_phul don/_sras po de nga'i bla ma'i sprul sku yin par spyan ras gzigs kyis lung bstan pa yin pas/_mi gzhan la gab cing sbas pa'i tshul gyis re zhig gtsang sbra che ba dang sku tshe'i rten 'brel mdzod/_phur pa de yang thugs tshags mdzad pa zhu lags zhib pa ngos kyis 'bul/_rten mu tig mdzod kyi za ma tog 'di yin/_zhes pa phyag bris ngos ma las b25 'dir bris pa yin no/_de skabs rgyal ba kar+ma pa chos dbyings rdo rje yar 'brog t19 kar mo gling du bzhugs yod 'dug par rten nged la ming zhu bar btang ba la/_bka' shog tu bu chung gi ming da lam gsal ma bde zhes gnang 'dug pa mngon mkhyen yin 'dug kyang/_bu chung la ming yang ma gnang zhes thugs 'khangs pa'i lo rgyus snang/_ de nas yang dus ring zhig na rnam sras gling du rig 'dzin yol mo pa nyid phebs te zhal ngo rnams la dbang chos srung zlog sogs kyi re ba skong ba dang /_khyad par kho bo la che du gtad pa'i lcags sdong ma sogs tshe dbang dang/_nyang gi drag po dmar chen/_byin rlabs thugs rje'i dbang lnga/_byang gling phyag rdor sogs kyi dbang 
gnang ba yin ces mchod dpon 'jam dpal sogs zer la/_dbang ci yin ma nges kyang nged rang gis deng sang yang dran par gzhis ka'i rtse gzims chung yang rtse'i sge'u khung sum ral shar du blta ba'i 'khris su bla ma nyid zhal byang gzigs su bzhugs pa dbu ral gyi khyon shing tu che ba/_snyan shal ring por snyan long 'chang ba/_tsan dan gyi phyag phreng rdog b26 po che ba phyag g.yon la dkris te dbang gnang ba'i zhal dkyil sogs gsal por dran/_ma sogs kyi zer rigs kho bos sku pang du 'dzegs te phyag dril la 'ju ba sogs kyang byas zer ba snang /_ de yang rig 'dzin ngag gi dbang po'i zhugs 'bul rje 'dis mdzad skabs/_dbu thod ril po pur khang gi shar sgor 'dril ba la rig 'dzin yol mo pa chen pos/_pha t20 rgan myur du 'byon par 'dug_nga la dbu thog tu bum pa zhog gsung rgyu yin 'dug kyang mi rgan rgyun ring rang e sdod mi shes gsungs pa ltar mi ring bar gzugs sku'i snang brnyan bsdus pas kho bo cag la de tsam las gsung gi bdud rtsi thob pa'i skal ba la byung yang skye ba 'dir rdo rje theg pa'i lam bzang po dang thog mar sprod pa'i yongs 'dzin bka' drin can 'di kho na lags so/_legs byas sa bon pha la'i zhing bzang por/_grub pa'i byin rlabs char gyis rab brlan cing /_thugs rje'i 'od zer drod kyis yongs smin pas/_dal 'byor skyon med myu gu gsar pa thon/_b27_rgyal ba'i bstan la tshangs spyod thos bsam dang/_'chad nyan sgom sgrub bgyi ba phra mo tsam/_'grub par dkar phyogs lha yis mngon rig nas/_dbyar gyi rnga sgra'i rgyal rnga lan gsum bsgrags/_mi mthun bdud sde'i dpung gi cho 'phrul las/_legs skyob tshe rabs kun gyi lhag pa'i lha/_dpal chen rdo rje gzhon nu rdzas kyi lha'i/_skur bzhengs bus pa nad gdon 'jigs las skyabs/_rig 'dzin grub pa'i gtsug rgyan yol mo pas/_smin byed dbang gi chu bo'i rgyun gtsang las/_mngal gyi dri ma yongs sbyangs bdag rgyud la/_rdo rje theg pa'i sku bzhi'i sa bon btab/_mgon khyod bu ram shing 'phel lang ka'i grong/_rim brgyud rnga yab dpal rir myur gshegs pas/_byis pa bor mod 'on te smon lam mthus/_phyi t21 mar tshom bu gcig tu mjal bar smon/_zhes 
pa yang smras so/_de ltar bus pa'i gnas skabs su spyi mthun gyi kun tu spyod pa las ngo mtshar gyi rnam thar bzang po byung ba'i rgyu mtshan ni ma mchis/_on kyang pha ma gnyis kyis legs b28 par bskyangs shing /_kho ba la nu ma bsnun pa'i ma ma ni med kyang pang na 'tsho ba'i ma ma dbyangs can dang /_gzhan yang nged rang gi a ce dgos dgos sogs kyis 'phral gyi mgo 'don dang /_byab khrus pa dge slong bgres po zhig dang bcas rang lo gnyis gsum bar byis pa'i kun tu spyod pas dus 'da' ba dang /_rim bzhin nar son nas byab khrus pa dge slong kun dga' rnam rgyal zer ba des rtse lugs kyi 'chams dbyangs 'dra shes pa kho bo bri phyir de rigs bgyis pa'i lad mo zlos shing 'chams rol gtor 'phen sogs kyi dus 'da' bar byas/_zhal ngo rnams kyang dag snang che bas grub mtha' ris med kyi bla ma bsten srol yod pa ltar de rnams kyis dbang 'dra gnang dus zhar chos su nyan cing bde chen chos 'khor gyi yongs 'dzin sprul sku rin po cher tshe dbang mang rab zhus shing drag po kI la ya sogs kyang thob pa yin 'dug pa bla ma de rang gi rnam thar du bkod 'dug cing byis par 'os pa'i nyer dpyad 'ga' gnang zhing byams par mdzad/_de mtshungs grwa sdings po che'i b29 sprul skur yang tshe dbang 'ga' shas thob cing nang rten gyi mjal kha zhus pa dran/_khyad par gter ston sangs rgyas t22 gling pa'i gdung dri ma med pa kong po snyi phu ba rig 'dzin dbang po lho mon phyogs nas phyir phebs pa'i lam zhor du gzhis kar phebs pa dang mjal/_nged rang na tshod phra yang yid shin tu dga' ba zhig byung zhing/_bla ma de ma bcos lhug pa'i rnam thar skyong zhing khyad par thugs shin tu gtum pas phyag phyi rnams la bka' skyon drag tu mdzad pa dran cing /_nged rang zhal ngo tshang mar tshe dbang dang sangs rgyas gling pa'i gu ru drag po'i dag shin tu rgyas par thob/_dbang gi tshe bla ma dkar chas pa yin 'dug pa dbang phod dang 'gan sbyar gos chen tshe ring ma zhig gsol/_dbu skra rgyab bsnyil steng dbang zhwa snyan pad dang bcas gzims chung bkra shis smon dgar bzhugs khri lho gzigs kyis bzhugs pa'i mdun du nged 
zhal ngo rnams bzhugs par bka' dbang grub rjes shel phreng brgya rtsa gcig_dar ser dmar kha gru re/_khro phur khro zhal yod pa zhig dang bcas bzhengs te phyag bstar nas nged la gnang ste/_b30 'phrin las bzhi 'grub pa'i rten 'brel yin no zhes lan mang por gsungs byung ba gsal por dran la/_sangs rgyas gling pa'i sman nag sogs kyi dam rdzas kyang mang rab gnang /_di ni rnying ma'i bla ma khungs ldan rtsod bral yin 'dug pas mjal go shin tu chod pa byung nges par snang /_de skabs zhig nas gzims dpon pad+ma yang nged rang gi zla bor dkris/_skabs de dag tu rig 'dzin yol mo pa sku cher bsnyun pa'i tshul bstan t23 nas mu tig shel nags kyi gzims spyil du bzhugs thog nged la ngos 'dzin gyi yo byad dag snang zla dkyil ma'i thang chung /_bla bre chung ngu sogs ljags bkod bcas phyi ltar yongs grags kyi ngos 'dzin rgyas par mdzad bzhed skabs/_ rje gong ma'i gnag dbon lha khang zhabs drung snying snying gis nged la tshod bgam pa'i phyir byon pa gral thog de gar ngos bzung sgam gyi lde mig gtad yod pa ga re zhes rtsad bcad pas khong pa yang yid ches kyi sgo nas mchi ma 'khrug pa dang bcas nang gi dngos spyad rnams bdag gir bgyis b31 zin pa'i lde mig kha shas lag tu gtad/_rje gong ma'i phyag mdzod sku mdun kun bzang dbang pos rtogs ldan du bsdus te ngos 'dzin yong res 'phrad par yongs par sgo nang du sleb ma thog_nged kyis sku mdun khyod 'di 'dra'i gzo sdug pa byas yod pa e yin khes smras pas khong pa yang mchi ma slogs te shugs ring nar gyis 'byin par byed/_de yang rang lo bzhi pa shing spre'i zla ba lnga pa dbyar zla ra ba'i tshes bcu'i dus chen thog rig 'dzin yol mo pa chen pos ngos 'dzin mnga' gsol dang bcas pa'i bka' shog dang/_pha ma rnams la yang bka' shog gi don 'bras/_rig 'dzin rgyal ba mchog gi sprul sku'i ngos 'dzin cha da lam gu ru'i dus chen khyad par can 'di thog tu rten 'brel gyi 'jug pa legs lam che nges su 'dug pa dngos ma 'di bzhin rdzong bda' zhus yod cing/_dus la ma t24 babs pa'i skyon 'dra mi yong snyam lags pa dgongs bzhugs dang sku'i skyed sring ba'i thabs tshul 
sgo gang zab yod pa zhu/_zhes sogs kyi bslab ston dang bcas rin po che dpal grags pa rdzong bda' gnang b32 zhing /_gang gi sku skye myur 'byon gyi gsol 'debs rigs kun khyab bdag gi tshig phrad rnams kyang brtan bzhugs su bsgyur te 'dzugs pa sogs bdag cag la brtse ba chen pos 'phral yun du bskyangs te/_tshes bcu de nyid kyi snga rol tshes lnga la rig 'dzin grub pa'i khyu mchog de nyid bu ram shing 'phel gyi gdul bya rjes su 'dzin pa'i phyir zhi ba'i dbyings su gzhol bar gyur te/_de'i tshul re zhig gsang khog nas rin po che dpal grags pa 'khor bcas nged kyi gam du 'byor te nyer dpyad rnams dang bka' shog sprad pa'i tshe/_nged kyi yol mo sprul sku shi nas med ces lan gnyis btud du smras pas gzhan rnams the tshom du gyur cing/_pha rgan gyis nged la bka' skyon par mdzad do/_ khong tshos rje gong ma'i phyag sbub pheg rdob chung ngu zhig yod pa'i bar tshangs sbas te nged la sprad pa/_'di'i bar tshangs 'di lta bu yod pa gar song zhes brtsad pas der 'khod rnams yid ches shing bar tshangs lag tu sprad par rten byis pa'i nyams kyis pheg rdob de kho na gces spras su byed cing b33 nyin mtshan med par 'khrol zhing bsdad/_ de ltar ngos 'dzin phran bu byas pa dang chos skyong khag gi lung bsdan/_gtso bor lha pa'i jo bo rin po cher brtag sgril phul ba thon pa/_rig 'dzin yol mo pa'i t25 snga phyi'i lung bstan sogs dang bcas 'khrul med du yid ches 'khul byas nas ngos 'dzin pa rnams phyir log/_nged sngar bzhin rtsed chos 'dra bgyid cing gnas pa'i bar mtshams su dbu can gyi klog 'dra bslabs/_bar skabs der rang lo lnga pa tsam la bi ma'i rnam sprul kong smyon he ru ka lha btsun nam mkha' 'jigs med sbas yul 'bras mo ljongs kyi gnas sgo 'byed par lung bstan dus babs kyi phebs zhor gzhis ka'i nye 'khor bde skyid rab brtan zhes pa'i skyed mos tshal gyi spang chal khar gzims gur mdzad de bzhugs/_'di skabs kong smyon rje khyim gyi skas la 'byon bzhud mi mdzad pa yin 'dug cing chibs drel sogs kyi spyos pa yang cher med pas lam du 'jug pa'i tshe phal cher he ru ka'i chas dang/_bka' dbang sogs dang rgyun ldan rab 
byung chas mdzad kyi 'dug b34 cing/_dpal ri dbon po tsam ma gtogs phyag phyi yang rtogs ldan chas sha dag tu 'dug pas/_ nged zhal ngo tshang mar gur nang du dkon mchog spyi 'dus gur drag seng gdong dang bcas pa'i dbang shin tu rgyas pa gnang zhing /_mchod dpon dpal ri dbon pos byas/_rtogs ldan at+ti'i ras gzan dang sgom thag gyon pa sbad mgo can zhig gis sbug chol dang rnga pa gnyis gsum bcas artsig nirtsi gi sngags byangs rol mo dang bcas sbub chol g.yas khyer g.yon khyer du 'khrol ba mthong bas rgod bro zhing nyams mtshar ba yang byung/_dbang don ngo 'phrod pa'i t26 zhib cha ma byung yang grub dbang chen po 'di las bka' 'brel thob pa yang shin tu legs pa'i char 'dug go/_gzhan yang de skabs chos rgyal dbang po'i sde yab sras gnyis ka'i dngos slob mod khams pa rin po che am ljag phyag rdor bkra shis su grags pa sku shin tu btsun pa sdor dkar gdan gcig gi brtul bzhugs gtsang ma dang/_mtshan bcas mtshan med kyi rnal 'byor la gcig tu b35 gzhol zhing bla ma yab sras dang dam tshig gi sel spu tsam gyis ma gos pa de nyid rig 'dzin ngag gi dbang pos e wam lcog sgar ba'i slob dpon du phyag nas 'thor ba de skabs kyang grwa gtsang gi bla ma mdzad bzhin pa de 'dus sder bcas te rnam sras gling du gdan 'dren mdzad cing/_grwa gtsang phyir phebs nas kyang rin po che dpon slob zhag shas bzhugs te bsrung zlog 'dra mdzad/_khyad par kho bo cag la de skabs rang lugs kyi brgyud pa sel med kyi bla ma yang dkon pa nas rin po che nyid nged rang gi bla mar 'os pa mthun grub che ba nas/_thog mar tshe sgrub lcags sdong ma'i tshe dbang brgya rtsa zhus pa nyin re la tshar kha shas re zhus shing /_nyang gi gter byon ma ra ti ka'i tshe bum la brten nas gnang ba yin par rin po che yang spobs pa shin tu zhan pa zhig yod pas tshig rnams thon dka' bas ma thon pa'i dus thugs yengs te tshe bum gyi zhabs ra nged kyi dpral bar nan gyis gtugs pas byis pa'i snang bar song bas sun snang shin tu che ba shig t27 byung yang tshe 'gugs kyi dus sngar gyi b36 phyag srol gyi rgyun bzang bas bla ma brag 
lha nas sogs kyis dbyangs rol mdzad pas yid drangs te dga' ba yang byung/_bla ma 'di las chos bum pa gang byor nyan pa'i skal ba byung na gong ma yab sras kyi brgyud pa 'di las khungs che ba zhig mi 'dug pas shin tu legs pa yod rgyur 'dug kyang/_rin po che 'di mi chos mi mkhyen cing nag chang sogs la shin tu bsneg pas kun spyod mi gtsang ba rnams mthar 'ded mdzad shis de skabs kyi kha gtso ba phal cher mi mthun phyags su gyur pas dbyen bcos te mi rigs pa'i phra ma mang pos che pos che gnyan rnams bsgul te mthar gzhung pa nas dgongs 'phog gi rnam pa zhig dang bcas/_kho bo khrir 'khod ma thag gnas nas dbyung ba'i cho gas lho brag mkhar chu dang tshe lam dpal ri sogs su tshe dang sgrub pa mnyam pa'i mthar sbas yul 'bras mo gshongs su zhi bar gshegs pas bshes gnyen dam pa de'i thugs dgongs chos bzhin du 'grub song yang/_dbang lung rgyun dkon pa sogs la kho bo chos kyis 'phongs pa'i rgyur song ba bdud b37 snying bzhugs kyi mi srun pa 'ga'i sgyu 'phrul las byung bar snang/_ kho bo de skabs byis pa'i kun tu spyod pas ston ka ri byi'i chu zhugs kyi chu rtsed skabs gram rdo ngos 'jam pa zhig dang/_rdo zur rno ba ring thung mdzub gang pa zhig la brtags pas/_'jam pa de'i ngos la 'od skor shin tu gsal ba'i nang du o rgyan za t28 hor ma'i sku'i dbyibs rdo dreg gis ri mo'i rnam par byas pa cung zad mi gsal tsam zhig dang/_rdo zur can de khyab 'jug mgo dgu bya rog gi mgo dang bcas pa smad sbrul 'jug dang bcas pa zhig tu mthong nas kun la bstan kyang/_byis pa'i kha la sdad ra 'cha' mkhan mi yong ba chos nyid du 'dug pa bzhin/_'dug 'dug/_lags lags zer ba'i blo 'brid tsam ma gtogs zhib ltas byed mkhan mi 'dug kyang nged rang gis 'tshal byas/_o rgyan gyi sku de bcos med du bzhag_gza' sku de lha bris par tshon gtong bcug pa shin tu dod pa zhig byung song yang zla bo tshos gnyan cha yong zer gza' sku de phrogs song ba nged rang yang tshig pa thos te gcig shos kyang phyi rol tu 'phangs pas gar song cha ma 'tshal/_b38_shing bya'i lo 'dir nged rang gi nu bo paN chen dkon mchog chos 
grags kyang btsas/_rig 'dzin yol mo pa'i gzigs snang zla dkyil ma'i rgyal mtshan che chung yang 'di la lta bar mngon cing/_nged ming sring bdun tsam yod pa'i nang nas nged gnyis chung ngus nas sger nye lta bur yod cing phyis nged gnyis ka rab tu byung ba thob cing rgyal ba'i bstan pa la bya ba cung zad kyang byed rgyu byung ba kun la gsal ba 'di lags/_de nas rang lo drug pa me khyi zla ba drug par nged gdan sar yong ba'i gra sgrigs byas 'dug pa/_di skabs gnyer pa'i 'gan 'khur rin po che dpal grags pa yin pas/_spyir dus 'gyur t29 dang bla ma yab sras rim par gzhan don du dgongs pa sogs 'khos khyer che ba zhig med kyang rgyu la dpags pa'i lha bshos ltar gra sgrig gi yo langs che bar rtsol ba mdzad pa'i/_dus la babs pa na rin po che aM ljag pa/_bla ma brag lha ba/_bla ma khro phu ba sogs dbu che mang po dang bcas pa'i bsu mkhan rnams 'byor ba dang bstun hor zla drug pa'i tshes dge b39 bar gzhis ka nas klu sdings su 'phags/_gang ci'i bkod shoms dang tsho 'dzin du pha rgan kyang byon pa'i nged rnams rim bzhin chas te yang kha gru brgyud pa'i gru khar sbyin bdag gi thog ma sgrags mda' lags kun ldan gyis bsnyen cing bkur/_ de nas tshes bcu'i snga dro thub bstan rdo rje brag tu grwa gtsang gzhis byes kyi 'dus pa'i tshogs kyi ser sbreng bzabs 'chor che ba dang /_mchod gzhis dang g.yas g.yon gyi yul pa'i skye bo rnams kyi bro gzhas sogs rtsed sna du ma dang bcas te thog mar gzims chung du slebs nges/_de nas cung zhig ngal gsos te tshogs su phyin pa de skabs tshes bcur thugs sgrub gtong ba'i byin 'bebs kyi skabs su mtshams bzhag ste ser sbreng sogs byas 'dug pa/_slar yang tshogs la 'khod de nged khri thog tu ma sleb bar mtshan brjod cig 'don gyi 'dug par bla ma brag lha ba spos phor ba yin pas nged kyi sngon du 'gro zhing/_da lam chig sra brtag dpyad byed zer gyi 'dug pa nged 'du khang gi sgo dang du sleb ma thog_chos kyi rgyal mtshan legs bar t30 'dzugs/b40_gsung ba dang 'grig pas khong gis kyang rten 'brel legs zer ba sogs la nye legs par go/_de nas khrir 'khod de gtso 
bor gzhung nas bsko ja'i gnang sbyin dang sku tshab tu ma sang mda' grong sdod pa mngags pa bzhin des thog drangs dbu che gra slob yon bdag sogs kyi legs 'bul rnams rim par bstar/_tshogs pa rnams kyis byin gshegs nas brtsams te 'phrin las tshul bzhin gyer ba'i mthar tshogs kyi 'khor lo'i dga' ston la longs spyad/_zhag shas bar legs skyes dang dga' ston sogs rim par blangs/_bla brang gong du gzhi ba rnams kyis mgron du bos shing bsnyen bkur dang 'bul nod stabs pa sogs phra zhib rnams bris par dgos pa chung bas bzhag/_de rjes 'bras spungs su gtsug phud 'bul bar chas te 'phreng po shel grong dang gsang la brgyud rim gyis dan bag gi gru bton nas pho brang chen po po ta la dang khad nyer 'byor skabs dbyings pa bsod nams chos 'phel 'bras spungs su chibs kha bsgyur ba dang 'grig pa'i nged rnams kyis rta las babs te gzur/b41_sku tshab grong sdod pa sku zhabs su phyag 'bul la byon song bar sde srid sku zhabs gsang bdar che bas nged rnams kyi rtsar khong pa phyir mngags te/_de ring lha sar song nged phyir 'khor bstun 'phros pa byed gsung ba ltar sku zhabs rtser snyan 'bul yang sde srid rang nas gnang 'dug pas/_de nub lha sar phyir phebs 'phral 'phyong rgyas nang so dngos grub t31 nged tsho'i par gnang ste/_sang nyin 'bras spungs su skra phud 'bul bar phyin chog tshul gyi bslab ston gnang byung ba dang bstun nged rnams kyis sang nyin snga char langs te phyin/_gangs ljongs kyi chos gra thams cad kyi gtsug gi rgyan rgyal byed tshal dang mi gnyis pa dpal ldan 'bras spungs kyi gtsug lag khang chen po/_sbyangs pa'i yon tan du ma dang ldan pa'i bshes gnyen stong phyag du ma 'du ba'i tshal klog pa thos bsam rig lung gi thal 'gyur 'phen pa'i sgras dir dir sor gyur pa'i chos grwa chen po de nyid phyogs su sleb ste ji srid bzhon pas bgrod pa de srid du bzhon pa dang /_de nas bzhon pa las babs te rkang gis rim par bgrod nas mtshan nyid grwa tshang chos b42 'khor gling gi brang khang du gnas bcas so/_de la thag 'gro ba lha dang bcas pa'i skyabs mgon nges pa don gyi thams cad mkhyen 
pa rgyal kun thugs rje'i rang gzugs 'phags mchog phyag na pad+mo'i rnam rol tshe rabs thams cad kyi yongs 'dzin mtshungs pa med pa rgyal dbang blo bzang rgya mtsho gang gi zhabs drung du bde bar son/_de 'phral bdog pa'i dngos po ring du brkyang ba'i phyag rten dang bcas te hor zla drug pa'i tshes bcu dgur zhabs brten gyi pad+mor yan lag mchog gis phyag bgyi ba dang lhan cig par skra phud phul te ming blo bzang pad+ma 'phrin las theg mchog dbang gi rgyal po yongs 'du'i sde zhes pa rtsal/_gzims dpon la blo bzang don grub ces pa gnang/_de rjes mgron khang du gdugs tshod skabs sku mdun 132 gyis gung thun bsam pa lhun grub ma bskul ba nged rnams kyis bton pa gsan pas rkyen byas/_slar yang de ma thag zhabs drung du shog gnang ba ltar nged dang pang du thogs pa'i gzims pon zla bor dkris te phyin pa la gsol 'debs le'u bdun b43 ma/_de dang rjes 'brel rang lugs kyi rten bskyed/_brgyud 'debs che chung/_u rgyan rjes 'jug ma'i kha skong dang bcas pa/_rje 'bangs nyer lnga'i gsol 'debs/_thugs sgrub sngags kyi las rim rnams ljags lung rtsal zhing tshe dbang lcags sdong ma smin byed thog ma'i bka' drin du nos/_de skabs 'gyur med kun tu bzang po'i mkha' dbyings las/_sprul pa'i zlos gar bsgyur ba'i nyin byed dbang/_zhes sogs kyi smon lam yang rtsal lo/_de nas nged cag rnams la bla bre/_gos dar/_rta la sogs pa'i zang zing gi gnang cha gya noms pas kyang chims par mdzad do/_phun tshogs skyed mos tshal gyi gzhi yangs por/_byis pa'i kun tu spyod pas nyer 'tsho yang/_sngon goms bag chags brtas dang lhan cig par/_rtse chos 'phrin sgrub zlos gar ci yang bsgyur/_rang gzhan grub mtha'i srol 'dzin bshes gnyen tshogs/_phyogs med dag pa'i snang bas legs bsten pas/_byin rlabs dbang gi chu bo rnam mang gis/_yongs rdzogs bstan pa'i smin grol snod tu byas/_thub bstan b44 e wam lcog sgar 'dus sde'i dbus/_rig 'dzin gong ma'i t33 zhabs rten seng ge'i khrir/_rnam mang rdo rje 'dzin pa'i 'dus pa yis/_lhag gnas bkra shis me tog lan brgyar gtor/_'bras dkar spungs 'dra'i chos grwa dga' ldan gyi/_yid dga' chos 
'dzin gnyis pa'i pho brang du/_rgyal ba'i rgyal tshab mi pham mgon lta bu'i/_kun mkhyen blo bzang rgya mtsho'i zhabs rtul bsnyen/_khyim nas legs byung skra dang kha spu bregs/_kun mkhyen bla ma'i slob bur deng gyur te/_'chi med tshe yi dbang sogs dam chos dang/_zang zing mi 'jigs byams pa'i brtse bas bskyangs/_zhes so/_de ltar 'bras spungs su skra phud phul rjes mchod mjal bgyis nas lha sar phyir 'khor te dga' ldan khang gsar du rgyal po mchod yon mjal zhing mgo 'dren bdag rkyen sogs ches che bar gnang/_lha ldan sprul pa'i gtsug lag khang dang ra mo che sogs mjal/_yun mi ring bar rang gnas su 'khor gros dbang rnams kyis thog b45 ma'i slob gnyer ci 'gab sogs 'gros par/_bla ma dpal grags pas ra ba smad lta bur phyin na 'gab tshul dang/_gong du sde srid sku zhabs nas deng sang na phra ba ma gtogs slob gnyer pher na ra ba stod lta bur bsdad pa 'gab tshul gyi bslab ston dang/_rgyal dbang mchog gi phebs sgor sngags pa'i bla mar mtshan nyid mkho chung bas mi 'gab tshul sogs byed bde ba zhig ma byung ba dang/_bla ma dpal grags tsam ma gtogs 'phral phugs kyi t34 khe nyen go ba ches dkon par rten re zhig gnas kyi slob dpon du sngags 'chang ngag dbang phun tshogs bsten nas/_thams cad blo mthun par 'tshong rings pa'i thog mar za chog rang gal che tshul ltar cho ga chos spyod 'dra dang dbang rjes gnang phran bu blo 'dzin byas/_rgyun gyi lag g.yog nged rang gi nye rigs dbon po rna 'on pa rnam sprul zer ba zhig dang/_bla ma dga' rab/_gzims dpon pad ma sogs kyis byas skabs shig bla brang gong du dpe khang gi ltad mor phyin pas mdo dbang gi tsak pod rnying pa rgyab yig lcags smyug gis dbu med du bris pa 'ga' klog pas sngan chod dbu chen 'byor b46 klog tsam las cher ma khrid kyang shur ma klog pa 'phral du shes pa dang byang ba dus mnyam pas 'bri gung dpal 'dzin la yon tan gzhan med kyang klog go chod cig 'dug zer ba'i lo rgyus ltar/_klog 'di chung ngu nas rang shes lta bur yod pas yon tan ngom rgyu 'di gcig po yin/_de skabs lo gzhon pas dgon pa dang rnam sras gling gnyis 
thags 'bran ltar byas pa'i dgon par sdod skabs bag grang dogs phal cher pha rgan rgyun bzhugs dang/_skabs 'gar a mi rgan po zhig yod pa de bzhugs pa brje len lta bur mdzad/_rnam sras gling du bsdad skabs zhig dpon slob sgam smyon sprul sku phyag rdor nor bu yang phebs pa'i tshe dbang sogs thob/_rig 'dzin yol mo pas nged kyi sngas srung la gnang ba'i drag sngags 'dus pa'i lcags phur yang de dus phyag mdzod kar t35 grags pas nged kyi ske nas dkrol te phrogs pa'i lo rgyus yod kyang smon lam gyi rten 'brel las phur pa de slar yun ring mo zhig nas lag tu 'khor ba da lta yod/_de mtshams tshe rabs kyi bla ma zur chen rdo rje 'chang chen po b47 chos dbyings rang grol phebs pa dang mjal zhing gnang skyes rgya cher gnang/_zings pa lugs kyi hri: gcig ma'i tshe dbang sogs bka' 'brel thog ma zhus/_rang lo bdun pa me phag rgyal zlar gung thang du phyin pa'i byang gter thugs rje chen po dang rig 'dzin gdung sgrub skor sogs zhus/_lo de'i zla ba gsum par rnam sras gling du grwa gtsang dang lhan cig bteg grwa gtsang gi zla gcig dang nged rang kyi rgyun ring bar bsdad/_bla ma chos nyid rang grol kong po ka thog dgon gyi bla mar bsko bzhag dang me tog 'thor ba sogs byas/_khams nas bla ma bsam gtan 'byor te 'bul nod rgya cher byas shing ngos 'phrad sogs kyis re ba bkang/_sde pa dbon po spun sogs kha shas kyi skra phud blangs te ming btags/_sbas yul 'bras mo ljongs nas lha btsun kun bzang rnam rgyal gyis nged rang la brtan bzhugs dang pha ma gnyis la yang so sor brtan bzhugs/_dam rdzas dang bdog pa'i gnang skyes sogs ched kyis mngags 'byor zhing tshigs bcad rnams grwa gtsang du 'phral 'dzugs mdzad song ngo/_rang lo brgyad pa sa byi'i nang du gung thang nas rje bla ma zur chen b48 rdo rje 'chang chen po dgon par phebs pa la dbang rjes gnang kha shas zhus/_khyed par nged la thog ma'i chos t36 sgo'i rten 'brel gyi sgo ngas 'byed gsungs te lcags sdong ma'i tshe dbang zhig chog khrigs gnang ba nged kyis bzung/_lcags sdong ma sprul sku yin kyang rten 'brel la dgongs tshe dpag med longs 
sku'i tsakli phyag bris su rtsal/_gza' skar dge ba zhig gi nyin rdo rje brag dbang khang du bcas shoms sgrigs pa'i thog nged kyis dbang sgrub kyi khul zin 'phral rje bla ma rang gis phyag dang dbang yon gyi gnang sbyin sogs sngon du 'gro bas/_grwa pa rgan gra thogs shas dang rnam gling nas pha ma sogs thogs shas la lcags sdong ma'i dbang zhig bskur/_de rjes grwa gtsang yongs rdzogs dang bcas par le'u bdun ma'i lung bklags pa sogs tshe 'di'i zog 'grim pa'i thog ma yin/_ de nas rje bla ma dang nged dpon slob lhan du rnam sras gling la phebs pa'i lam bar gcur du zhag bzhugs nub/_nged rang gi a mi lags chab kyis snyun yod pa de nub gshegs pa'i bang phyin srod 'khor la byung 'phral b49 bla ma dam pas chibs kha bsgyur ba'i bya skad dang po tsam la gzhis kar phebs 'pho ba gsal 'debs sogs gnang rjes/_zhi khro gzhan phan 'od kyi 'khor lo'i dkyil 'khor la brten nas lam sbyang bstan mdzad pa'i thugs rje dang/_das po yang lhag bsam dge zhing yig drug dung 'phyur song ba sogs mthong chos kyi 'bras bus mon mkhar rang gi g.yog rigs drag pa bde skyid khang gsar ba'i bur skyes nas khrims ldan dge sbyor la gzhol t37 ba dge slong tshul khrims legs pa'o/_de res bla ma dam pa yar klungs bkra shis rtse chos sder khyab bdag bka' 'gyur ba'i zhabs drung du mtshar lugs kyi zab chos rnams gsan par thegs pa'i yar lam rnam gling du phebs/_rjes gcod kyi sku rim pad gling gur drag gi gtor zlog dang zhal ngo tshor tshe dbang sogs gnang/_nged dang ma rgan la gzims chung yang rtser byang gter thugs rje chen po'i ras bris kyi dkyil 'khor du smin byed kyi dbang bskur rgyas par gnang ba yin/_nged kyis de res gzhis kar bsdad thog snga ma'i sa bcad la zla ba bcu gnyis pa'i lo mjug tu b50 grwa gtsang dang sbrags rdo rje brag gi dus rim ji lta ba'i gtor zlog 'chams dang bcas rgyas par byed rgyu'i rtsis kyi 'chams chas sogs snga 'gros su song grub kyang a mi lags kyi gnas shis stabs sku rim ma bde yang/_grwa gtsang rdo rje brag nas 'phral 'byor gyi bdun tshigs rnam la thugs rje chen po'i cho ga sogs gshin po'i sgrib sbyong 
dang/_rgyun ldan tshe gzungs 'bum ther gsog pa sogs zhag nyi shu tsam bzhugs/_gdung chog grol ba'i ser tshogs kyi nyin nged rang gi grwa gtsang dang 'phyong rgyas bkra shis sde chen/_bying bsam gtan rtse sogs dge lugs kyi grwa gtsang/_g.yas g.yon gyi dgon chung khag bcas ser tshogs kyi gral dbur nged kyis phyin pa'i bsngo ba dang gral dbu'i thog ma 'di yin/_de nas nged kyis gzhis kar bsdad/_grwa gtsang snye mor bteg shul rdo rje brag gi 'du khang sngar t38 sde pa 'phreng po ba'i tshoms chen yin 'dug shis 'du khang gi rnam dbye dang shing rtsi sogs med par rten gnyer pas khur blangs te bshus bkab byas/_seng g.yabs ka ring gnyis b51 dang khyon ka ba bcu gnyis kyi sa shing rtsi dang bcas pa/_gtsang khang du rig 'dzin ngag gi dbang po'i dgongs rdzogs su rig 'dzin yol mo pas bzhengs pa'i gser zangs kyi thub chen dge 'dun sprin gyi g.yas g.yon du nye sras brgyad/_nyan thos mchog zung/_khro bo gnyis dang bcas pa'i ldem zangs chus byung sa bcas bzhengs pa de lo grub pa'i dga' ston thog nged rang grwa gtsang bcas pas rab gnas kyi cho ga byas/_de skabs nged rang tshogs su bsdad pa tsam las cho ga sogs cher mi shes pas me tog 'thor ba tsam mo/_a mi lags kyi dgongs rdzogs su dmigs rnam sras gling nas mtshan brgyad kyi sku khru gang tsam gsar bzhengs gnang ba dgon par spyan drangs/_grwa rgan rnams kyis gzungs 'bul sogs grub rjes/_zur chen thams cad mkhyen pa chos dbyings rang grol rdo rje brag tu gdan phebs te bka' brgyad bde gshegs 'dus pa'i dkyil 'khor du dngos sta nyin gnyis ma'i rab gnas rgyas par gnang zhing da lta mtshan brgyad lha khang du bzhugs pa 'di'o/_de skabs tshe dbang dang sgyu 'phrul rtsa rgyud b52 gsang snying/_lo brgyad ma rig 'dzin 'phrin las rnam rgyal gyi chog khrigs spyan snga skal ldan rgya mtsho las brgyud pa'i ljags lung sogs gsung chos phran bu thob/_t39 rang lo dgu pa sa glang zla ba dang por rnam sras gling nas pha ma sogs 'gro pher gang yod bteg pa'i sku zhabs yas phyin gyi zhal mjal phyag dbang dang lha sa mjal ba sogs la 
lhan du bteg/_mjal phyag rnams legs par grub bstun khong zhal ngo rnams phyir log/_nged rjes su bsdad pa'i zla ba gnyis pa'i nyer gcig chos rgyal dbang po'i sde'i dus dran nyin gru 'dzin gnyis pa pho brang po ta lar khyab bdag phyag na pad+mo kun mkhyen blo bzang rgya mtsho'i zhabs drang du snga por nas rang lugs kyi chos bka' tshan che bar dgos tshul gsol ba btab pa bzhin gnas snying zhabs drung rin po che/_sku zhabs grwa gtsang gi grwa pa rags bsdus bcas nged chos nyan pa bdun cu skor la gzims chung khams gsum du ras bris kyi dkyil 'khor la brten pa'i byang gter bla ma rig 'dzin gdung sgrub kyi rab 'byams bka' b53 dbang chen mo/_thugs sgrub drag po rtsal gyi dbang rgyas pa sgrub sde brgyad dang 'brel ba/_rgya zhang gter byon 'jam dpal gshin rje gshed 'khor 'das kyi phyag rgya zil gyis gnon pa'i pad gnubs dbang gi chu bo gcig tu 'dres pa nges don bde 'jug la/_chos rgyal dbang po'i sde'i phyag bzhes ltar bam chen gsang ba nas kha bkang ba'i slob ma sta gon dang khams gsum yongs sgrol gyi dbang/_zor dbang/_mchod rten gyi dbang/_rdo rje slob dpon gyi dbang sogs shin tu rgyas par nos shing/_zor dbang dus t40 sku chas zhugs sogs shin tu spros pa che ba bka' drin bskyangs/_di skabs kho bo na phras pas slob bu chas mjug gi drag chas bgo ba sogs ma byung bar brten zor dbang gi chas 'jug zhabs phyi gnas snying zhabs drung gis mdzad/_gzhan yang mnga' ris paN chen gyi zab gter rig 'dzin yongs 'dus las bsam pa lhun grub ma'i sgrub skor gu ru yon tan gter mdzod kyi dbang lung yongs rdzogs dang /_'chi med dpal ster gyi tshe dbang yang bka' drin du rtsal/_ nged dpon slob drug la b54 las 'brel rtsal gyi zab gter khyab 'jug dug gi spu gri'i dbang bskur bka' rgya ma ches zab pa bka' drin gyi dpyid du nos/_ kho bo cag gcig por yongs rdzogs dge bsnyen yang bka' drin du rtsal zhing mthar zang zing gi gnang cha gya nom pa dang bcas chos 'byor gnyis ka'i dpal gyis phyug bzhin rang gnas su phyir log/_di skabs snga phyi ma nges pa zhig la khams nas bla ma gar dbang rgya mtsho zer 
ba zhig byung bar 'dod sbyar gyi dbang lung phran bu bgyis te khong pa 'bras mo ljongs su song ba yin/_po ta la nas 'khor ba'i zla ba bzhi par rnam sras gling du rib tsam phyin skabs bkra shis rtse nas khyab bdag bka' 'gyur ba chen po 'jam mgon bsod nams mchog ldan 'dus sde dang bcas gdan $t 41$ 'dren gnang ba'i/_nged bla ma 'di dang mjal ma thag nas mos gus ches cher skyes/_bla ma dam pas kyang thog mar sgrol dkar yid bzhin 'khor lo 'od zer drug sbrag tu grags pas chos sgo phye ste thub pa rdo rje gdan gtso 'khor gsum pa'i rjes gnang /_'phags pa thugs b55 rje chen po yi ge drug pa'i rjes gnang /_'jam dpal dpa' bo grub pa'i rjes gnang /_dbyangs can dkar mo phyag gnyis ma'i rjes gnang /_tshe dpag med grub rgyal lugs lha gcig bum gcig gi rjes gnang dang rta mgrin dpa' bo gcig pa grub rgyal lugs kyi rjes gnang /_phyag na rdo rje 'byung po 'dul byed kyi rjes gnang dang mthar grub chen thang stong rgyal po'i lugs kyi tshe dbang brgya rtsa bcas bka' drin du nos shing /_dam pa 'di dang chung ngu nas mjal ba'i rten 'brel dang mig bltos kyi khul byas deng sang btsun tshugs ma zhig tsam yong na 'di'i thugs rje lags par sems/_lo de nyid kyi nang du nged grwa gtsang bcas snye mor 'gro ba'i sgo dod/_'di yan chod du tshe sgrub lcags sdong ma dang nang longs spyod rdzogs skur bsgrub pa tshe sgrub longs sku ma sogs la rkyen sel gyi bsnyen pa bdun phrag re gnyis song zhing/_rgyun ldan ltar chags kyi khul gu ru pad+ma'i thun drug gsol 'debs dang nub mo thugs sgrub sngags kyi 'phrin las kyi gzhung bsrangs te yi dam rnams la bzlas pa 'os 'tshams dang chos skyong rnams la gter bsngo/_b56 de rjes sher snying /_'khor t42 lo 'bar ba/_yang bzlog sogs zla bo gang yod dang sgrigs 'don byed pa sogs chag med kyi khungs dang rang lugs kyi dbyangs rol 'chams sogs kyang sbyong khul byas/_zla ba bzhi par snye mo phyogs su phyin pa'i de yang chos rgyal byang pa'i dngos slob/_lhang lhang dang kham bu lung gi zab gter gdan 'dren pa'i gter g.yog/_sngon gu ru chos dbang gis gnas de nas gter 'don pa'i tshe gter bdag 
mchod par bos pa'i bon po gnyis kyi skye bar dbang po'i sdes ngos 'dzin gnang ba sde pa dgon nas pad dkar lhas sbyin bgres po des 'phrin las kyi sgo 'byed du dmigs nged rang grwa gtsang bcas 'bod par ched kyis mngags pa'i bya ma rta byung ba bzhin gza' tshes dge bar dgon pa nas bteg/_skyid gshongs bde ba can du sleb pa'i nub rnam sras gling nas pha ma gnyis kyang nged skyel bar 'byon rtsis kyi de nub 'byor/_sang nyin lhan du phebs te gong dkar chos sde'i mdun du bzhon pa las babs te phyag btsal nas gong dkar zhol du bsdad/_rdzong bzhugs b57 khyams stod nas nged 'phrad par byung/_de'i sang pha ma gnyis kyang gong dkar gyi rgyab tsam du bskyal nas phyir thegs/_nged tshos chu bo ri'i gru bton nas khro phur sleb/_de skabs sha nad cig gis gzims dpon gyis gtsos kha shas na yang shi chad ma byung/_ de nas rim bzhin yul chos dang thon mdar bcag mal byas te/_de'i sang sde pa rang snye mo bkra shis gling du thab bsur byon pa dang mjal zhing t43 rim gyis sde pa dgon pa ba'i rdzong bong ra lhun po dpal 'bar du bde bar 'byor/_lam gyis dub pa ngal gsos te sde pas nged bshul du 'dong ba'i dpon slob thams cad la phebs spro'i bsnyen bkur rgyas par mdzad/_der zla ba gcig gi bar mkho dgu'i snyed pa stabs shing/_gtso bor sde pa rang gi dad rten mtshan brgyad kyi sman sku gsar bzhengs mdzad par rab gnas kyi ched du yin 'dug pas bla ma rig 'dzin gdung sgrub kyi rdul tshon gyi dkyil 'khor rgyas par bzhengs te dngos sta nyin gnyis ma'i rab gnas 'dus tshogs dang lhan cig bgyis/_bsnyen sogs dag par ma byas par/_dkyil 'khor las b58 la mjug mi bya/_zhes gsungs pa'i gzhung don la chu bun gyis byugs/_nged kyis gong smos ltar tshe bsnyen drag bsnyen phran bu las mang sang yang khyim bdag dad pa can gyi ngo ma zlog pa dang bcas bab chol du rab gnas kyi thog ma bgyis/_de bzhin du sde pa'i rim gror tshe bdag gi gtor zlog zhag bdun bsgrubs pa'i sgrub khang nang gi rdo rje slob dpon nged rang dang phyi rol tu zor 'phen sngags 'chang ngag phun gyis byas/_sde pa yab yum sras mo 
gnyis dang bcas par nyin re bzhin tshe dbang lcags sdong ma bcu grangs re bskur te zhag shas nas brgya rtsa 'grig par byas/_de dus sde pa de dad pa stobs su gyur pa'i shugs dang/_chung ngus nged rang gi grwa pa yang mdzad myong 'dug cing rgyus che bar rten tshes bcu yar ngo mar ngo/_dgu gtor/_lha bsangs gsum/_bla ma gong ma'i dus dran gyi sku mchod dus gtor sogs thams cad la $t 44$ mchod pa dang tshogs 'khor sogs gang rgyas mdzad cing/_nged kyang rgyun tshogs dang 'gyu dus brgyad tsam ma gtogs dus gtor thams cad la tshogs su b59 'gro srol yod pas lha bsangs kyi nyin gcig nged rang gi khri'i mdun du cog rtse'i khar dkar yol bsgrigs pa'i mdun logs su bsangs dpe bzhag pa sgul skyod langs par rten phyi nur byas pa thengs shig thog gi ar zhal steng thing sgra dang bcas lhungs song bar sde pa nged rang gi 'khris su yod pas blangs te gzigs song ba/_dkar yol gan dkar shin tu srab pa yin kyang gas tshag spu tsam ma byung 'dug pa/_de ma thag bzhengs te dbu skra sa nyil rgyab bskyur mdzad pa'i phyag 'bul mdzad cing/_g.yon pas dkar yol bzung g.yas pa'i mdzub mos thing sgra bskul ba dang bcas grwa pa rnams la ngom zhing grub rtags zer na 'di la zer gsung gi 'dug pa/_nged la grub rtags kyi re ba ci la yod kyang stabs legs dang kho rang dam tshig gtsang ba'i ltas su go 'o/_spyir snye mo 'di sngar paN chen sku mched gnyis kas zhabs kyis bcags shing khyad par rig 'dzin rjes yun ring por bde legs gling du bzhugs/_rgyal sras pad ma chos rgyal yang snye mo rang du 'khrungs shing yun ring bzhugs pa dang/_de mtshungs b60 chos rgyal dbang po'i sde yab sras kyang yang yang phebs shing zhabs kyis bcags pa'i thugs rje dang byin rlabs zhugs nyams kyi rang phyogs la deng sang bar shin tu gus par yod/_de skabs bla ma brag lha nas kyang ngos 'phrad la 'byor te nyin mo bzhugs gral re ltar chags dang /_skabs 'gar tshogs 445 'khor sogs ston mo'i skabs rnams su bla ma dpal grags pa dang 'khong gnyis 'bel gtam 'dra yang glengs/_phral yun gyi bsnyen bkur dang mkho dgu'i ster cha gya nom 
pa byung zhing bong ra rdzong du zla gcig song nas/_snye mo bra rdzong du nged rang gi mchod gzhis kyi snyed pa la rgyang tsam longs spyad/_de bar sde pa snye mo ba sku gzhon pas smon mkhar du grwa gtsang dang lhan du bos/_zhag gnyis gsum tsam bsdad/_rdor dril khyad can sogs 'bul nod che bar byung/_dbang sogs kyang byas/_de mtshungs mdo mkhar du yang phyin pa'i dbang sogs bgyis pa'i lam zhor lha bris dang dbang bdag sogs su phyin/_zhabs drung rje btsun drung gis gzhis ka'i klu sdings su nyin 'khor zhig la bos par yang b61 phyin pa sogs mchog dman so so'i blo dang bstun pa'i gang zer bgyis/_de nas phyir log par nye skabs slar yang sde pa dgon nas kyis thab skyel dang bcas bkra shis gling du sleb/_sde pa bgres song nged la 'phral yun gyi bslab bya du ma dang bcas phyag thal mo sbyar te spyan chab mang du bsil ba mthong bas nged rang yang mchi ma shor/_rten 'brel des de phyin mjal ba zhig ma byung/_mar lam yang thon/_yol chos/_khrus phu sogs rim par brgyud 'ongs pa'i thon nas bzung nged ma zhu ba'i nad kyis btab pa khrus phur cher na nas grwa gtsang sngon la btang nged rjes su sdod dgos pa yang byung/_ de bar bla t46 ma khrus phu bas zhabs tog dang gong dkar chos sde'i lugs kyi su t+ra'i 'chams sogs ltad mo phul/_khong tsho'i zhal ngo skyed tshal ba'i mkhan po bgres po shig gis nged la byab khrus kyang mdzad/_de nas khams kyang rim bde'i ngos nya srab kyi ko ba thon dpal de nas a ce lags dang gru khar mjal/_de nub byang thang du sleb par gnam ngo shin tu che ba zhig kyang byung ba lkog gyur gyi rgyu mtshan zhig b62 tu go/_de nas nged dang grwa pa rags bsdus kyis gtsang po lho brgyud rnam sras gling du shar mar phyin/_rgan byis rnams dgon par slog nged rnam gling du sleb 'phral ma zhu ba'i nad ro cung zad 'phar yang myur du pos/_grwa gtsang gis zhag nyi shu skor dang nged kyis rgyang tsam bsdad/_de skabs bkra shis rtse nas 'jam mgon bka' 'gyur ba chen po rnam sras gling du spyan drangs pa dang mjal/_tshe rta sogs zhus/_de nas phyir 
'ongs te rang lo bcu pa lcags stag zla ba gsum par 'bras spungs su rgyal dbang mchog gi zhabs drung du bsnyen te nyang gi drag dmar rtsa ba dang /_byang gter 'chi bdag zlog pa'i skor dang de'i chog khrigs rgyal dbang mchog nyid kyis mdzad pa 'chi bdag g.yul las rgyal ba'i ru mtshon/_rgyang gi gter skor kha shas dang byang gter lo rgyus sogs ljags lung kha shas/_khyad par rdzogs chen zang thal gyi cha lag las can gyi bla sgrub tu grags pa nyi zla 'od 'bar gyi sgrub thabs chig brgyud ma rig 'dzin ngag gi dbang po/_rig 'dzin yol 447 mo pa/_ rje zur b63 chen sogs las chig brgyud kho nar bzhugs pa de sogs dgyes bzhin du rtsal ba bka' drin du nos/_phyir lam gung thang du zur chen rdo rje 'chang gi zhabs pad yul ring por bsnyen skabs byang gter thugs sgrub drag po rtsal thems can thems med/_byang gter phur pa lugs gsum/_tshe bdag lcags sdig lcags 'dra/_byang gter spyod dbang skor/_bri gung dgongs pa yang zab rnams kyi ljags lung dang /_phyag rdor dregs 'dul dang kar+ma gu ru'i dbang lung /_sku gsum rigs 'dus kyi lung dang grwa pa'i dzam dmar gyi dbang lung /_sa lugs dzam dmar srog sgrub dang lha mo ti nu'i rjes gnang sogs mang bar thob/_skabs shig tshal gyi gnas mjal la phyin pa'i yang dgon zhabs drung spyan snga skal ldan rgya mtsho dang yang mjal zhing gnas mjal yang zhib par byung /_yer pa dang nye 'dabs gar phu dgon du zhabs phyir phyin pa'i kar+ma gling pa'i zab chos zhi khro dgongs pa rang grol gyi sgrub dbang chen mo dbang phran dang bcas pa zhag bco brgyad tsam gyi bar rgyas par gnang ba'i grol dbang gi nyin khrom shin tu che bar tshogs/_b64 rje bla mas dbang phod pad zhu sogs dbang chas mdzad/_nged kyi yang gangs zhu gyon te gtor dbang reg pa don ldan bskur ba'i zhabs phyi zhus/_dus der bskyed rdzogs skor gyi ljags lung rags rim tshogs chos su gnang /_lung gi 'phros rnams dang t48 'og sgo'i skor sogs zab gnad 'ga' phyir phebs nas chos khri bla brang du bka' drin bskyangs/_di skabs rgyal dbang mchog gi drung yig chos lung a khu 'og gdon gyis snyun 
pa'i bcos la gung thang du byon pa dang 'grig pa'i khong pa rang lugs la dad zhen che zhing nang gtsang ba dang yi ge legs pa bcas/_gza' tshes bzang ba zhig la bla ma'i zhabs drung du khong gi ka dpe dang bcas yi ge bslabs pa'i mjug skyong rnams sngags 'chang ngag phun pas byas/_ de skabs 'jam mgon bka' 'gyur ba chen po yang gung thang du phebs pa dang 'grig pa'i snga dro gzims khang shar du rje zur chen gyi zhabs phyir phyin pa'i rje bka' 'gyur bar nyang gi drag dmar/_mkha' 'gro gsang rdzogs/_bka' brgyad rang shar gyi ljags lung sogs b65 rnying ma'i skor mang po dang /_dur khrod bdag po'i rjes gnang sgrub skor/_jam dbyangs mkhyen brtse'i rnam thar gyi lung sogs pa lugs skor kha shas zhus/_phyi dro chos khri bla brang du rje zur chen la chos zhu pa sogs thob rgya che ba byung /_ de skabs pad gling gsum pa gsung sprul rje tshul khrims rdo rje gung thang du phebs pa dang 'grig pa'i mjal 'dzom zhus/_skyes chen 'di mdo sngags rig gnas kyi gsan gzigs che zhing sprul sku rtsod bral yin 'dug shis bla mar shin tu 'os gras yin 'dug kyang /_nged rang na phra zhing gzhan dbang du song bas chos nod pa'i skal ba ma byung/_rnam sras gling dang mchod yon 449 'brel zab cing yang yang phebs pa'i tshe sgrub rdor phreng gi sgrub chen sogs mang bar gnang 'dug kyang nged yod pa dang stabs 'grig cig ma byung yang nged rang yang dad pa che zhing tshur yang dag snang gis brtan bzhugs dang zhu yig 'bul len sogs zhib par byung zhing /_phyis nged rang gis bskul ngor bdud rtsi sman sgrub kyi reg zig cig kyang gnang ba yin/_dar rgyas chos sdings nas rig 'dzin 'phrin las lhun grub nyid gung b66 thang gi phebs zhor rdo rje brag tu yang yang phebs shing nged kyis kar+ma gu ru'i dbang phul ba sogs phan tshun legs lam che yang gong ltar gzhan dbang gis chos zhu ba'i skabs ma rnyed/_bla ma 'di gsan gzigs rgya che zhing khyad par rnying ma bka' gter la chos spyan shin tu yangs pa zhig 'dug pa dang /_dbang lung khrid gsum gyi brgyud pa mang por bzhugs shing mos gus che bar yod/_lha 
btsun nam mkha' 'jigs med 'bras ljongs nas phyir phebs pa'i lha sar phebs zhor rdo rje brag tu ched gtad phebs/_nged la tshogs su brtan bzhugs skabs/_khor 'das kha sbyor dag pa nam mkha'i bzhin/_zhes sogs kyi gsung rtsom tshogs 'don du btsugs/_chos rgyal dbang po'i sde'i dus dran gyi mchod pa'i bka' brgyad rang shar gyi cho gar tshogs su lhan du phebs/_ dpon slob rang gi dbon po chung ngu zhig grwa gtsang gi sgrigs 'grim du rdzong ba gnang /_ nged kyis skra phud blangs pad+ma phun tshogs dbang gi rgyal po bstan pa'i nyi mar btags/_t50 'dis gsang 'grel mun sel la grwa skor dang lo gsum sogs b67 bgyis pa'i deng sang dar rtse mdo sgar gyi bla mar yod pa 'di yin/_de skabs gzims chung du gsung gleng zhib pa dang /_nang rten gyi mjal kha phar 'bul tshur zhu byas/_bras ljongs lha ri rin chen snying po nas hrum sgrub gnam lcags thog mda' dang lhan du spyan drangs pa'i nor bu klu'i gtsug tor gyi mjal kha gnang zhing lo rgyus mang po gsungs byung ba gam la ma zin yang spyi bor blangs shing gsol ba btab pas ring bsrel dmar po yungs 'bru che tshad tsam zhig kun gyi mthong par nged kyi pang du lhungs byung bar kong smyon rjes gzigs te rten 'brel legs btsan sar rdzongs gsungs byung ba de 'phral mid/_'di skabs rig 'dzin srog sgrub kyi rtsa ba'i chos bdag gi nang tshan/_de 'og 'jam dpal gshin rje'i sprul/_zer ba de nged la ngos 'dzin mdzad/_lho nas phun tshogs nor bu'i ming /_zhes nged kyi pha dang /_dpal gyi bsam yas lho phyogs su/_sgrol ma'i 'od zer bud med lus/_sgeg mdzes gdong la sme bas brgyan/_di 'phrad rang bzhin grol bar 'gyur/_zhes pa nged kyi mar ngos 'dzin mdzad pa b68 sogs sgo du ma nas sku dngos la chos nyan pa zhig byung na dgongs pa'i rten 'brel 'ga' zhig bsgrig pa gnang yang nged tshwa tshwa 'ga' 'ga' ma'i gras yin shis gong 'khod ltar rang dbang ma 'dus par lus/_on kyang de res gung thang du rig 'dzin t51 srog sgrub kyi chos bka' phye dus chos bdag yin tshul dang /_phugs lag tu 'phrod pa dgos tshul sogs zur chen rdo rje 'chang la zhib par gnang 'dug pa bzhin 
dbang khrid lung gsum smin rgyas thob cing /_deng sang yang nyams len dang 'chad khul bgyid bzhin pa yin/_rje gsung sprul/_kong smyon/_dar sdings pa gsum la de skabs chos zhu thub na snga 'gyur bka' gter la chos kyis mi 'phongs pa zhig yong rgyur 'dug kyang bdag gi bsod nams kyi skal bar ma gyur/_de tsam du ma zad rgyal dbang thams cad mkhyen zhabs chen pos 'bras spungs su rdo rje phreng ba'i bka' dbang gnang rgyu'i gnas tshul byung skabs/_nged mon mkhar du yod pas pha rgan gyis rdo rje phreng ba'i dbang bskur 'gangs che ba dang gnang b69 mkhan gzhan dang mi 'dra ba dang /_grub mtha' thams cad kyi bla ma yang tshogs yod 'dug pas nged rang la yang phyin pa 'gab tshul nan chags gnang byung yang /_sngags 'chang ngag phun gyis rnying ma ba la rdo rje phreng ba'i dbang gi mkho med zer thag bcad pa'i ram gnyer pa tshos 'gro sgor bsams te btegs pas dbang skal chad par rten da lta'i bar du rdo rje phreng ba'i dbang ma thob pa'i nang du song bas 'di rigs yi ger bris pa dgos pa chung yang 'jig rten pa'i kha ngag la/_nga 'dra ma cig khyod 'dra'i dpe ltar bla ma dang sprul skur ming btags pa'i rigs rnams che 'gying dang sbom ldir ma che/_sdig grogs kyi dbang du ma btang bar chos t52 kyi rigs zhu gang thug mdzad par snying nas gsol ba bdebs so/_grub mtha'i phyogs ris rigs rus che mtho'i brag/_cher rlom khengs pa'i ri bo ma snyil bar/_dam chos bdud rtsi'i gter dang mi 'phrad pas/_ris med bla ma bsten la chos nyon cig_bod 'dir mu stegs byed kyi lugs med pas/_grub mtha'i srol 'dzin kun kyang nang pa'i lugs/_yin phyir rang gzhan sde ris chags b70 sdang gis/_las ngan chos la ma gsog phyi rabs rnams/_dam chos kun la rang rang 'bras bu yod/_de phyir zab dgu nyon la yid ches gang /_nyams su blangs pas phyogs med gnad kun lon /_yongs rdzogs bstan la zhugs shig rjes 'jug rnams/_zhes pa yang gdams so/_ 


\section{Bibliography}

\section{Oft-Cited Works in Tibetan}

Fifth Dalai Lama, Ngakwang Lozang Gyatso (ngag dbang blo bzang rgya mtsho) (16171682). "byang pa rig 'dzin chen po ngag gi dbang po'i rnam par thar pa ngo mtshar bkod pa rgya mtsho." In bka' ma mdo dbang gi bla ma brgyud pa'i rnam thar. TBRC W21523. : 443 - 570. Leh: S.W. Tashigangpa, 1972. Mentioned throughout as The Wondrous Ocean.

Guru Trashi (gu ru bkra shis) (b. $18^{\text {th }}$ c.). gu bkra'i chos 'byung. TBRC W20916. pe cin: krung go'i bod kyi shes rig dpe skrun khang, 1990. http://tbrc.org/link?RID=W20916. Mentioned throughout as The Guru Trashi.

Padma Trinlé (padma 'phrin las) (1641-1717). "The life of the author, Rdo-brag Rig-'dzin Padma-'phrin las." in bka' ma mdo dban gi bla ma brgyud pa'i rnam thar: Accounts of the eminent masters of the 'Dus-pa-mdo tantra. Leh: S. W. Tashigangpa, 1972. p. 409-419.

Pema Trinlé (padma 'phrin las) (1641-1717). "rig 'dzin mnga' ris pa chen po legs ldan bdud 'joms rdo rje'i mam thar." In bka' ma mdo dbang gi bla ma brgyud pa'i rnam thar. TBRC W21523. : 351 - 392 (335-376). Leh: S.W. Tashigangpa, 1972. Mentioned throughout as The Biography of Rindzen Lekden Dorjé.

Padma Trinlé (padma 'phrin las) (1641-1717). pad+ma 'phrin las kyi rang nyid kyi rtogs brjod rab dkar shel gyi me long. TBRC W23811. Unpublished. Mentioned throughout as The Clear White Mirror. In the context of the transliteration, this is the Tmanuscript. 
Padma Trinlé (padma 'phrin las) (1641-1717). pad+ma 'phrin las kyi rang nyid kyi rtogs brjod rab dkar shel gyi me long. TBRC W00KG02749. 2 vols. [s.1.]: [s.n.], [n.d.]. In the context of the transliteration, this is the B-manuscript.

\section{Works in Tibetan}

Guru Chöwang (gu ru chos dbang) (1212-1270). "ghu ru chos dbang gis rnam mthar bka' rgya brgyad ma." In gu ru chos dbang gi rang rnam dang zhal gdams, vol. 1. 65-151. Paro: Ugyen Tempai Gyaltsen, 1979.

Jamgön Kongtrül Lodrö Tayé ('jam mgon kong sprul blo gros mtha' yas) (1813-1899). gter ston brgya rtsa'i rnam thar. TBRC W20539. Tezu, Arunachal Pradesh: Tibetan Nyingmapa Monastery, 1973.

Karma Migyur Wangpo (karma mi 'gyur dbang rgyal) (b. 17th c.). gter bton gyi lo rgyus gter bton chos 'byung. TBRC W19709. Darjeeling: Taklung Tsetrul Pema Wangyal, 1978.

Kunga Drönchok (kun dga' grol mchog) (1507-1565). "shAkya mchog ldan gyi rnam thar zhib mo rnam par 'byed pa ." In gsung 'bum/shAkya mchog ldan. TBRC W23200. 16: 11 - 244. new delhi: nagwang topgyel, 1995.

Kunzang Drödül Dorjé (kun bzang 'gro 'dul rdo rje) $\left(18^{\text {th }}-19^{\text {th }}\right.$ c.). thub bstan rdo rje brag dgon gyi byung ba mdo tsam brjod pa ngo mtshar bai DU r+ya'i phreng ba. TBRC W00KG03797. 1 vols. [s.1.]: [s.n.], 2004. http://tbrc.org/link?RID=W00KG03797. Note: While the author is listed as this $18^{\text {th }}-19^{\text {th }}$ century figure, there are biographies of figures who lived in the $20^{\text {th }}$ and $21^{\text {st }}$ century. This shows evidence that the book has been updated. 
Lodrö Gyeltsen (blo gros rgyal mtshan) (1235-1280). "kho phu lo tsA ba la bskur ba." In "'gro mgon 'phags pa blo gros rgyal mtshan gyi gsung rab." In sa skya bka' 'bum. TBRC W00EGS1017151. 15: 677-678. Kathmandu: Sachen International, 2006.

"bla ma rnams kyi rnam thar 'od kyi 'phreng ba." (circa late-15 ${ }^{\text {th }}$ c.) In byang gter lugs kyi rnam thar dang mang 'ongs lung bstan. TBRC W27866. 1 vols. Gangtok, Sikkim: Sherab Gyaltsen and Lama Dawa, 1983. http://tbrc.org/link?RID=W27866. 173-206.

Nyima Zangpo (nyi ma bzang po) $\left(14^{\text {th }}-15^{\text {th }}\right.$ c.). "sprul sku chen po'i rnam thar gsal byed nyi ma'i 'od zer (ga)." In byang gter lugs kyi rnam thar dang mang 'ongs lung bstan. TBRC W27866. : 53-152. Gangtok, Sikkim: Sherab Gyaltsen and Lama Dawa, 1983. Mentioned throughout as The Ray of Sunlight.

Sönam Gyatso (bsod nams rgya mtsho). 2009. "khro phu lo tsA ba'i rnam thar" In $b k a^{\prime}$ brgyud chos 'byung nor bu'i phreng ba. TBRC W1KG4232. 1: 87 - 90. [s.1.]: [s.n.], [n.d.].

"thugs sras nam mkha' rgyal mtshan gyi rnam thar mthong ba don lden ma rig mun sel." (circa late-15 $5^{\text {th }}$ c.) In byang gter lugs kyi rnam thar dang mang 'ongs lung bstan. TBRC W27866. 1 vols. Gangtok, Sikkim: Sherab Gyaltsen and Lama Dawa, 1983. http://tbrc.org/link?RID=W27866, 207-234.

Trashi Topgyel (bkra shis stobs rgyal) (1550-1603). pad+ma 'byung gnas kyi rnam thar. TBRC W8873. 1 vols. Gangtok: Sherab Gyaltshen Lama, 1976. http://tbrc.org/link?RID=W8873

Tupten Gyeltsen (thub bstan rgyal mtshan). 1992. "Abridged Biography of the Author [Padma Trinlé]" (mdzad pa po'i lo rgyus mdor bsdus). in The [Potala] Catalog of the Collected Works of Nyingma Authors (mying ma'i gsung 'bum dkar chag). Lhasa: S.N., 1992, 271-273. 


\section{Western Language Sources}

Ahmad, Zahiruddin. Tr. 1999. Sanis-rGyas rGya-mTSHo: Life of the Fifth Dalai Lama Volume IV, Part I. New Delhi: International Academy of Indian Culture and Aditya Prakashan.

Aris, Michael. 1989. Hidden Treasures and Secret Lives. London and New York: Kegan Paul International.

Bärlocher, Daniel. 1982. Testimonies of Tibetan Tulkus: A Research Among Reincarnate Buddhist Masters in Exile. Zürich : Tibet-Institute, 1982.

Bogin, Benjamin E. 2005. The life of yol mo bstan 'dzin nor bu: A critical edition, translation, and study of the memoirs of a seventeenth-century tibetan buddhist lama. Ph.D. diss., University of Michigan.

Bogin, Benjamin E. 2006. "Royal Blood and Political Power: Contrasting Allegiances in the Memoirs of Yol Mo Bstan 'Dzin Nor Bu (1589-1644)." In Power, Politics, and the Reinvention of Tradition: Tibet in the Seventeenth and Eighteenth Centuries: PIATS 2003: Tibetan Studies: Proceedings of the Tenth Seminar of the International Association for Tibetan Studies, Oxford, 2003. Managing Editor: Charles Ramble. ed. Brian Cuevas and Kurtis Schaeffer. Leiden and Boston: Brill.

Boord, Martin. 1993. The Cult of the Deity Vajrakila: According to the Texts of the Northern Treasure Tradition of Tibet (Byang-gter phur-pa). Tring: The Institute of Buddhist Studies.

Brauen, Martin. ed. 2005. The Dalai Lamas: A Visual History. Chicago, Serindia Pub.

Dalton, Jacob. 2002. The Uses of the Dgongs Pa 'Dus Pa'i Mdo in the Development of the Rnying-Ma School of Tibetan Buddhism. Ph. D. diss., University of Michigan. 
Dalton, Jacob. 2006. "Recreating the Rnying ma School: The Mdo Dbang Tradition of Smin Grol Gling." In Power, Politics, and the Reinvention of Tradition: Tibet in the Seventeenth and Eighteenth Centuries: PIATS 2003: Tibetan Studies: Proceedings of the Tenth Seminar of the International Association for Tibetan Studies, Oxford, 2003. Managing Editor: Charles Ramble. ed. Brian Cuevas and Kurtis Schaeffer. Leiden and Boston: Brill.

Davidson, Ronald M. 2002. Indian Esoteric Buddhism: A Social History of the Tantric Movement. New York: Columbia UP.

Davidson, Ronald M. 2005. Tibetan Renaissance: Tantric Buddhism in the Rebirth of Tibetan Culture. New York: Columbia UP.

Doctor, Andreas. 2005. Tibetan Treasure Literature: Revelation, Tradition, and Accomplishment in Visionary Buddhism. Ithaca, NY: Snow Lion Publications.

Dolgyal Research Committee. "A Brief History Of Opposition To Shugden." The Tibetan Government in Exile Website. (Retrieved: March 17, 2007).

Douglas, Nik and Meryl White. ed. 1976. Karmapa: The Black Hat Lama of Tibet. London: Luzac \& Company Ltd.

Dreyfus, Georges. 1998. “The Shud-den Affair: History and Nature of a Quarrel.” Journal of the International Association of Buddhist Studies 21. no. 2 (1998): 227-270.

Dudjom Rinpoche ('Jigs-bra1 ye-shes rdo-rje). 1991. The Nyingma School of Tibetan Buddhism. Trans. Rdor-rje 'Gyur-med and Matthew Kapstein. Boston: Wisdom Publications, 1991.

Eckel, Malcolm David. 1992. To See the Buddha: A Philosopher's Quest for the Meaning of Emptiness. San Francisco: HarperSanFrancisco. 
Goldstein, Melvyn C. 1973. "The Circulation of Estates in Tibet: Reincarnation: Land and Politics." Journal of Asian Studies 32, no. 3 (1973): 445-455.

Gyatso, Janet. 1986. "Signs, Memory and History: A Tantric Buddhist Theory of Scriptural Transmission." JIABS 9 no. 2 1986: 7-35.

Gyatso, Janet. 1994. "Guru Chos-dbang's gTer 'byung chen mo: an early survey of the treasure tradition and its strategies in discussing Bon treasure." Occasional Papers Institute For Comparative Research In Human Culture I(I): 275-287.

Gyatso, Janet. 1998. Apparitions of a Self: The Secret Autobiography of a Tibetan Visionary. Princeton: Princeton University Press.

Gyatso, Janet and David Germano. 2000. "Longchenpa and the Possession of the Dākinī." In Tantra in Practice. David Gordon White. ed. Princeton: Princeton University Press, 239-265.

Gyurme Dorje. 2005. Footprint: Tibet. $3^{\text {rd }}$ Edition. Bath: Footprint.

Herweg, Jurgen Wilhelm. 1994. The Hagiography of Rig 'dzin Rgod kyi ldem 'phru can and Three Historical Questions Emerging from It (M.A. thesis), University of Washington.

Hirshberg, Daniel Alexander. 2012. Delivering the lotus-born: Historiography in the tibetan renaissance. Ph.D. diss., Harvard University.

Jackson, David P. ed. 1990. Two Biographies of Śākyaśrībhadra: the eulogy by khro-phu lo-tsa-ba and its "commentary" by bsod-nams-dpal-bzang-po. Hamburg: The Institute for the Culture and History of India and Tibet at the University of Hamburg.

Jamgön Kongtrül Lodrö Tayé ('jam mgon kong sprul blo gros mtha' yas) (1813-1899). The Hundred Tertöns: A Garland of Beryl: A Brief Account of Profound Terma and 
the Siddha Who Have Revealed It. Trans. Yeshe Gyamtso. New York: KTD Pub., 2011.

Kapstein, Matthew. 2006. The Tibetans. Malden, MA: Blackwell Pub.

Karmay, Samten Gyaltsen. Ed. 1988. Secret Visions of the Fifth Dalai Lama: The Gold Manuscript in the Fournier Collection. by ngag dbang blo bzang rgya mtsho (Fifth Dalai Lama, 1617-1682). London: Serindia.

Lemmen, M. M. W. 1990. Max Weber's Sociology of Religion: Its Methods and Content in Light of the Concept of Rationality. Hilversum: Gooi en Sticht, 1990.

Martin, Dan. 1997. Tibetan Histories: A Bibliography of Tibetan-Language Historical Works. London: Serindia Publications.

Michael, Franz. 1982. Rule by Incarnation, Tibetan Buddhism and Its Role in Society and State. Boulder: Westview Press.

Mills, Martin A. 2003. Identity, Ritual and State in Tibetan Buddhism: the Foundations of Authority in Gelukpa Monasticism. London \& New York: RoutledgeCurzon.

Parsons, Talcott. 1922. "Introduction." in Max Weber. The Sociology of Religion. Ephraim Fischoff. trans. Boston: Beacon Press, 1993 (1922).

Richardson, H. E. 1993. Ceremonies of the Lhasa Year. London: Serindia Publications.

Rindzin Dorje (rig 'dzin rdo rje) (Martin Boord). trans. 2010. A Roll of Thunder from the Void: Vajrakila texts of the Northern Treasures Tradition: Volume Two. Berlin: Wendel Verlag,

Ronis, Jann Michael. 2009. Celibacy, revelations, and reincarnated lamas: Contestation and synthesis in the growth of monasticism at katok monastery from the 17th through 19th centuries. Ph.D. diss., University of Virginia. 
Samuel, Geoffrey. 1993. Civilized Shamans: Buddhism in Tibetan Societies. Washington D.C.: Smithsonian Institution Press.

Samuel, Geoffrey. 2012. Introducing Tibetan Buddhism. New York: Routledge.

Schaeffer, Kurtis R. 2006. "Ritual, Festival and Authority under the Fifth Dalai Lama." In Power, Politics, and the Reinvention of Tradition: Tibet in the Seventeenth and Eighteenth Century Tibet: Proceedings of the International Association for Tibetan Studies, Xth Seminar, Oxford University, 2003. Kurtis R. Schaeffer and Bryan J. Cuevas, Editors. Leiden: Brill Pub., 187-202.

Smith, Gene E. 1973. "Preface" In rdzogs pa chen po dgonis pa zan thal and ka dag rain byun ran śar: Collections of treasured teachings of the Rdo-rje-brag (Byan-gter) tradition of the Rñin-ma-pa. S. W. Tashigangpa, Leh. 1973. pp. iii-i, 1-7.

Smith, Gene E. 2001 Among Tibetan Texts: History \& Literature of the Himalayan Plateau. ed. Kurtis R. Schaeffer. Boston: Wisdom Publications.

Smith, Jonathan Z. 1987. To Take Place: Toward Theory in Ritual, Chicago Studies in the History of Judaism. Chicago: University of Chicago Press.

Snellgrove, David L. 2002. Indo-Tibetan Buddhism: Indian Buddhists and Their Tibetan Successors. Boston: Shambhala.

Sørensen, Per K. 2007. Rulers on the Celestial Plain. Wien: Verl. Der Österr. Akad. Der Wiss.

Stein. R. A. 1973. "Un ensemble sémantique tibétain: créer et procréer, être et devenir, vivre, nourrir et guérir." Bulletin of the School of Oriental and African Studies XXXVI: $412-423$.

Strong, John S. 2001. The Buddha: A Short Biography. Oxford: Oneworld. 
Thondup, Tulku. 1984. The Tantric Tradition of the Nyingmapa: The Origin of Buddhism in Tibet. Marion.

Thondup, Tulku. 2011. Incarnation: The History and Mysticism of the Tulku Tradition of Tibet. Boston: Shambhala.

Thurman, Robert A. F., trans. 1988. The Holy Teaching of Vimalakīti. University Park, Pa.: Pennsylvania State Univ.

Trungpa, Chogyam. 2009. The Mishap Lineage: Transforming Confusion into Wisdom. Boston: Shambhala.

Ye-śes-mtsho-rgyal $\left(8^{\text {th }}\right.$ c.). The Life and Liberation of Padmasambhava. Revealer. Orgyan-glin-pa (1323-1360). Ed. Tulku Tarthang. Trans. Ken Douglas and Gwendolyn Bays. Berkeley, CA: Dharma Pub., 1978.

Ye-śes-mtsho-rgyal $\left(8^{\text {th }}\right.$ c.). The Lotus-born: The Life Story of Padmasambhava. Revealer. Nyang-rel Özer (nyang ral nyi ma 'od zer) $\left(12^{\text {th }}\right.$ c.). Trans. Erik Pema. Kunsang. Boston: Shambhala South Asia Editions, 1999.

Weber, Max. 1922. The Sociology of Religion. Ephraim Fischoff. trans. Boston: Beacon Press, 1993 (1922).

Wylie, Turrel V. 1978. "Reincarnation: A Political Innovation in Tibetan Buddhism.” In Proceedings of the Csoma de Körös Memorial Symposium. Budapest: Akademiai Kaido. 